\title{
$\begin{array}{llllll}S & \mathrm{~T} & \mathrm{U} & \mathrm{D} & \mathrm{I} & \mathrm{A}\end{array}$
}

\section{Sergiej Polechow}

https://orcid.org/0000-0001-7866-7663

Instytut Historii Rosji Rosyjskiej Akademii Nauk

Szkoła Aktualnych Badań Humanistycznych Instytutu Nauk Społecznych

Rosyjskiej Akademii Gospodarki Ludowej i Służby Państwowej

\section{Itinerarium wielkiego księcia litewskiego Witolda: 4/5 sierpnia 1392-27 października $1430 *$}

\begin{abstract}
Zarys treści
W artykule przedstawiono itinerarium wielkiego księcia litewskiego Aleksandra Witolda w okresie od 1392 do śmierci w 1430 r., opracowane na podstawie bogatego zestawu źródeł, zarówno drukowanych, jak i dotąd nieopublikowanych, przechowywanych w archiwach i bibliotekach Białorusi, Litwy, Łotwy, Niemiec, Polski, Rosji i Ukrainy, z uwzględnieniem literatury przedmiotu. Analiza itinerarium Witolda na tle praktyki objazdów dokonywanych przez władców w innych krajach Europy średniowiecznej pozwala stwierdzić, że w Wielkim Księstwie Litewskim, inaczej niż w sąsiednim Królestwie Polskim za Władysława Jagiełły, nie ukształtował się system regularnych objazdów kraju. Hospodar litewski spędzał większość czasu na Litwie właściwej i w ziemi grodzieńskiej, natomiast wyjazdy do peryferyjnych części władztwa i poza jego obszar podejmował jedynie w związku z realizacją konkretnych zadań, zarówno w zakresie polityki wewnętrznej (utwierdzenie władzy wielkiego księcia), jak i zagranicznej (spotkania z innymi władcami, wyprawy wojenne).
\end{abstract}

\begin{abstract}
The article presents the itinerary of Grand Duke Vytautas of Lithuania (1392-1430) on the basis of extensive source material, both published and unpublished, preserved in the archives and libraries of Belarus, Germany, Latvia, Lithuania, Poland, Russia, and Ukraine; the relevant literature is also

\footnotetext{
* Praca powstała w okresie stażu podoktoranckiego na Wydziale Historycznym Uniwersytetu Wileńskiego (projekt pt. Kształtowanie się systemu zarządu ziemiami ruskimi Wielkiego Księstwa Litewskiego w XIV-XV w.), finansowanego w ramach programu funduszy strukturalnych Unii Europejskiej „Realizacja stażow podoktoranckich (postdoc) na Litwie” w latach 2013-2015, a później uzupełniona o nowszą literaturę (do 2019 r.). Pragnę złożyć podziękowania wszystkim kolegom i koleżankom, którzy przyczynili się do powstania tekstu i podzielili się swoimi uwagami. Są to w szczególności: T. Baranauskas, A. Baranow, R. Biespałow, R. Dediala, B.N. Floria, A. Gąsiorowski, W. Gułewycz, D. Heckmann, A. Hrusza, T. Jaszczołt, S. Jóźwiak, A. Krasnożon, O. Kudriawcew, K. Kwiatkowski, O. Lickiewicz, W. Michałowski, G. Rutkowska, A. Szweda, S. Szybkowski, N. Śliż, M. Wołkau i D. Wróbel.
} 
taken into account. The analysis of Vytautas' itinerary against the background of the rulers' travelling practice in the other countries of medieval Europe leads to the conclusion that no system of the ruler's regular tours emerged in the Grand Duchy of Lithuania, unlike in neighbouring Poland under Władysław Jagiełło. The grand duke of Lithuania spent most of his time in Lithuania proper and in Grodno land, leaving the core of the state for the outlying districts and foreign states in connection with specific tasks of home and foreign policy, such as strengthening his power, meetings with other rulers and war expeditions.

Słowa kluczowe: Wielkie Księstwo Litewskie, Witold, itinerarium, objazdy monarsze, system sprawowania władzy

Keywords: Grand Duchy of Lithuania, Vytautas, itinerary, monarch's journeys, system of exercising power

\section{Wprowadzenie: itinerarium Witolda a problem mobilności wielkich książąt litewskich}

Itinerarium, czyli „krytycznie opracowane zestawienie miejsc i dat pobytów badanej osoby" ${ }^{1}$, zajmuje ważne miejsce w warsztacie badań nad dziejami Wielkiego Księstwa Litewskiego, szczególnie w średniowieczu. Badacze wykorzystywali dane o miejscach pobytu wielkich książąt litewskich już od XIX w., a później rozpoczęli opracowywanie itinerariów systematycznych, które pozwalały stawiać nowe pytania i odpowiadać na nie. W wyniku tych prac obecnie itineraria wielkich książąt litewskich opracowane są jednak bardzo nierównomiernie ${ }^{2}$. Problematyka ta doczekała się wielu szczegółowych badań w polskiej historiografii ${ }^{3}$, jednak najbardziej dopracowane są wykazy podróży tych wielkich książąt, którzy jednocześnie zajmowali także tron polski - Władysława Jagiełły ${ }^{4}$, Kazimierza Jagiellończyka ${ }^{5}$, jego synów Aleksandra ${ }^{6}$ i Zygmunta Starego oraz Zygmunta

1 A. Gąsiorowski, Rec. pracy J. Purca, SŹ, t. 18, 1973, s. 246; zob. też Gąsiorowski 2015, s. 32-33, 35 (wykaz skrótów na końcu artykułu); P. Węcowski, Polskie itineraria średniowieczne i nowożytne. Przegląd badań i propozycje badawcze, SŹ, 37, 2000, s. 14.

2 Szczegółowy przegląd literatury przedmiotu zob. P. Węcowski, op. cit. oraz we wstępach do wskazanych niżej itinerariów władców.

3 Zob. zwł. A. Gąsiorowski, Długoszowe itineraria królewskie, „Roczniki Historyczne” 36, 1970, s. 109-126; idem, Stacje królewskie w średniowiecznej Polsce, „Kwartalnik Historii Kultury Materialnej” 20, 1972, nr 2, s. 244-265; idem, Podróże panującego w średniowiecznej Polsce, „Czasopismo Prawno-Historyczne” 25, 1973, nr 2, s. 41-67 (wersja ang.: Rex ambulans, „Quaestiones Medii Aevi” 1, 1977, s. 139-162); idem, Polskie itineraria późnośredniowieczne, ZH, t. 50, 1985, nr 3, s. 221-237; A. Gąsiorowski, I. Skierska, Średniowieczna monarchia objazdowa. Władca $w$ centralnych ośrodkach państwa, w: Sedes regni principales. Materiały z Konferencji. Sandomierz, 20-21 października 1997 r., Sandomierz 1999, s. 67-80.

${ }^{4}$ Gąsiorowski 2015.

${ }^{5}$ G. Rutkowska, Itinerarium króla Kazimierza Jagiellończyka 1440-1492, Warszawa 2014 (Itineraria Jagiellonów, t. 1).

${ }^{6}$ K. Pietkiewicz, Itinerarium króla Aleksandra Jagiellończyka 1492-1506, Warszawa 2016 (Itineraria Jagiellonów, t. 3); recenzja pierwszych tomów tej serii: R. Krajniak, Itineraria Jagiellonów. 
Augusta $^{7}$ i Stefana Batorego ${ }^{8}$. W 2014 r. zaczęto wydawać serię Itineraria Jagiellonów ${ }^{9}$ pod redakcją Antoniego Gąsiorowskiego i Grażyny Rutkowskiej. Prace wydane w ramach tejże serii zapoczątkowały nową epokę w tym nurcie badań naukowych. Inicjatorka serii - Izabela Skierska (1967-2014) - niestety nie doczekała edycji pierwszych tomów. Przy tym w itinerariach Kazimierza i Aleksandra uwzględniono okresy, gdy zajmowali oni nie tylko tron polski, ale także litewski, czyli lata 1440-1447 i 1492-1501. W 2016 r. w aneksie do książki piszącego te słowa pomieszczono opracowane przezeń itineraria wielkich książąt litewskich Bolesława Świdrygiełły i Zygmunta Kiejstutowicza ${ }^{10}$.

Pierwszą próbę opracowania itinerarium Witolda podjął polski uczony Kazimierz Sochaniewicz, ale wyniki jego pracy pozostały $\mathrm{w}$ rękopisie ${ }^{11} \mathrm{i}$ zostały tylko częściowo wykorzystane $\mathrm{w}$ jego artykułach ${ }^{12}$. Nie zostało także opublikowane itinerarium Witolda, które w latach 60. XX w. opracowywał Marceli Kosman ${ }^{13}$.

Uwagi i uzupetnienia do kolejnych tomów serii, „Klio. Czasopismo Poświęcone Dziejom Polski i Powszechnym" 44, 2018, nr 1, s. 149-167; por. też S. Polechow, Kilka uwag historyka Wielkiego Księstwa Litewskiego do itinerarium Kazimierza Jagiellończyka. [Rec.:] Grażyna Rutkowska: Itinerarium króla Kazimierza Jagiellończyka 1440-1492. Warszawa, Wydawnictwo Neriton, 2014, ss. 422, 8 s. map, „Średniowiecze Polskie i Powszechne” 8, 2016, s. 287-299.

7 A. Gąsiorowski, Itineraria dwu ostatnich Jagiellonów, „Studia Historyczne” 16, 1973, nr 2(61), s. 249-275. Dla pierwszych lat rządów Zygmunta Starego zob. też Н.Г. Бережков, Итинерарий великих князей литовских по материалам Литовской метрики (1481-1530 г2.), „Археографический ежегодник за 1961 год” 1962, s. 180-205; P. Kozák, Mezi centrem a periferii. Itinerář pozdèjšího krále Zikmunda I. Starého $z$ doby jeho pobytu $v$ Uhrách a $v$ českých zemích (1498-1507), w: Jagiellonowie i ich świat. Dynastia królewska w drugiej połowie XV i w XVI wieku, red. B. Czwojdrak, J. Sperka, P. Węcowski, Kraków 2015 (Studia Jagiellonica, t. 2), s. 117-171.

${ }^{8}$ M. Wrede, Itinerarium króla Stefana Batorego 1576-1586, Warszawa 2010.

9 Zob. wyżej, przyp. 4, 5, 6.

10 С.В. Полехов, Наследники Витовта. Династическая война в Великом княжестве Литовском в 30-е годы XV века, Москва 2015, s. 541-557 (książka faktycznie ukazała się dopiero w styczniu 2016 r.).

11 J. Purc pomyłkowo twierdził, że rękopis ten znajduje się w Bibliotece PAN w Krakowie; idem, Itinerarium Witolda wielkiego księcia Litwy (17 lutego 1370 roku - 27 października 1430 roku), w: Studia z dziejów Wielkiego Księstwa Litewskiego XIV-XVIII wieku, Poznań 1971 (Zeszyty Naukowe Uniwersytetu im. A. Mickiewicza, Seria: Historia, z. 11), s. 71; za nim tak samo P. Węcowski, op. cit., s. 17. W rzeczywistości spuścizna po Kazimierzu Sochaniewiczu zachowała się w Bibliotece Narodowej im. Wasyla Stefanyka we Lwowie, f. 108, przede wszystkim sygn. 52/n17, $62 / n 22,88$. Niestety, nie mogłem uwzględnić jej podczas opracowania niniejszego itinerarium, a informacja o niej pochodzi od prof. Leonida Tymoszenki z Drohobycza, któremu pragnę w tym miejscu podziękować. Por. też S.K. Kuczyński, Sochaniewicz Kazimierz Roman, w: PSB, t. 39, Warszawa-Kraków 1999-2000, s. 625.

12 Sochaniewicz 1925-1926, s. 374-386. Nieco później w artykule Z. Ivinskisa umieszczone zostało opracowane przez niego itinerarium Witolda, uwzględniające tylko daty pobytu tego władcy w Trokach; idem, Trakų Galvés ežero salos pilis, „Vytauto Didžiojo Kultūros muziejaus metraštis" 1, 1941, s. 154-159.

${ }_{13}$ M. Kosman, Kancelaria wielkiego księcia Witolda, SŹ, 14, 1969, s. 91, przyp. 1; idem, Dokumenty wielkiego księcia Witolda, SŹ, 16, 1971, s. 139-169. 
W 1971 r. ukazało się itinerarium Witolda autorstwa polskiego badacza Jerzego Purca ${ }^{14}$. Natychmiast stało się przedmiotem krótkiej recenzji Antoniego Gąsiorowskiego ${ }^{15}$, który równolegle badał problematykę podróży władców polskich po ich ziemiach. Zauważył on, że itinerarium jest nieścisłe i niepełne, autor korzysta zaś - i to bezkrytycznie - z prac badaczy zamiast świadectw źródłowych. Podsumowując, recenzent stwierdził: „Itinerarium tego księcia czeka w dalszym ciągu na właściwe opacowanie". Sprawdzenie danych podanych przez Purca, dokonane przez piszącego te słowa, pokazało, że to same źródło czasami występuje w itinerarium kilkakrotnie - według różnych wydawnictw, w których podane jest pod różnymi datami; przy czym wykorzystane zostały nie tylko edycje in extenso, lecz także regesty - wydane przez Karla Eduarda Napiersky'ego, Ignacego Daniłowicza i Anatola Lewickiego ${ }^{16}$. Zrozumiałe, że źródła archiwalne nie zostały wykorzystane dla opracowania tego itinerarium. Pomimo uściśleń, uzupełnien ${ }^{17}$, kolejnych uwag krytycznych i wezwań do ponownego opracowania itinerarium ${ }^{18}$, praca Purca pozostaje jednak po dziś dzień najbardziej aktualnym itinerarium Witolda.

Od czasu publikacji tejże pracy do obiegu naukowego weszły nowe źródła, a te znane już wówczas usystematyzowano i ponownie przeanalizowano. Pojawiły się nowe studia - dotyczące biografii Witolda ${ }^{19}$, jego dworu ${ }^{20}$, kancelarii i sposobów komunikacji z poddanymi ${ }^{21}$ oraz wojen, w których brał

14 J. Purc, op. cit., s. 71-115.

15 SŹ, t. 18, 1973, s. 246-247.

16 IC I; SD I i II; IA.

17 Zob. przede wszystkim: Tęgowski 2006.

18 Zob. np. W. Zawitkowska, Walka polityczno-prawna o następstwo tronu po Władysławie Jagielle $w$ latach 1424-1434, Rzeszów 2015, s. 188, przyp. 84; K. Kwiatkowski, Zygmunt Luksemburski wobec konfliktu Królestwa Polski $i$ Wielkiego Księstwa Litwy z zakonem niemieckim wiosna 1410 roku - kilka nowych uwag, „Nowe Studia Grunwaldzkie” 2, 2016, s. 49. Nieco enigmatycznie natomiast wygląda sformułowanie w A3P II, s. 480: „Итинерарий Витовта достаточно детально не разработан".

19 J. Nikodem, Witold, wielki książę litewski (1354 lub 1355 - 27 października 1430 roku), Kraków 2013; M. Jučas, Vytautas Didysis, Vilnius 2013.

${ }^{20}$ R. Petrauskas, Vytauto dvaras. Struktūra ir kasdienybè, „Naujasis Židinys - Aidai” 2003, nr 1-2, s. 39-44; idem, Didžiojo kunigaikščio institucinio dvaro susiformavimas Lietuvoje (XIV a. pabaigoje - XV a. viduryje), LIM, 2005 [2006], nr 1, s. 5-38 (wersja polska: Kształtowanie się instytucji dworu wielkoksiążęcego w Wielkim Księstwie Litewskim (koniec XIV - połowa XV wieku), „Politeja” 2011, nr 2(16), s. 155-185); R. Čapaite, The Everyday Life of Grand Duke Vytautas of Lithuania According to Contemporary Correspondence, „Lithuanian Historical Studies” 8, 2003 [2005], s. 1-26.

${ }^{21}$ S. Szybkowski, Polish Staff as a Social Group in the Chancery of Grand Duke Witold, „Quaestiones Medii Aevi Novae" 3, 1998, s. 75-94; idem, Kancelaria wielkiego księcia Witolda w dobie wielkich konfliktów z Zakonem Krzyżackim w latach 1409-1422. Organizacja, zadania, personel, w: Kancelaria wielkich mistrzów i polska kancelaria królewska w XV wieku, red. J. Trupinda, Malbork 2006, s. 299-318; R. Čapaitė, Gotikinis kursyvas Lietuvos didžiojo kunigaikščio Vytauto raštinèje, Vilnius 2007; eadem, List jako narzędzie komunikacji wielkiego księcia litewskiego Witolda, SŹ, t. 50, 2012, 
udział $^{22}$. To pozwoliło znacznie uściślić trasy jego podróży. Istotne znaczenie mają badania nad dyplomacją i dyplomatyką Wielkiego Księstwa Litewskiego oraz sąsiednich państw, przede wszystkim zakonu krzyżackiego. Najdokładniej skomplikowaną procedurę zawarcia umów zbadał Klaus Neitmann ${ }^{23}$. Okazuje się, że Witold bynajmniej nie zawsze brał osobisty udział w wystawianiu dokumentów i zawieraniu układów opieczętowanych jego pieczęcią, dlatego warto przy opracowaniu itinerarium korzystać $\mathrm{z}$ nich bardzo ostrożnie. Nie mniej ważne są itineraria władców sąsiednich, z którymi spotykał się Witold - króla polskiego Władysława Jagiełły i wielkich mistrzów krzyżackich ${ }^{24}$.

Podstawowymi źródłami dla odtworzenia itinerarium Witolda są wydane przez niego dokumenty (dotyczące zarówno zarządzania państwem, jak i polityki zagranicznej) i listy ${ }^{25}$ oraz źródła narracyjne - kroniki Wiganda z Marburga, oficjała pomezańskiego (nazywana w literaturze także kroniką Jana Posilge lub de Redden), najstarsza kronika wielkich mistrzów, dzieło Jana Długosza, Latopis wielkich książąt litewskich, a także latopisy pochodzące z ziem ruskich. Najlepiej źródła te ukazują podróże wielkiego księcia litewskiego od ok. 1410 r. Właśnie od tego czasu gwałtownie wzrasta ilość dokumentów zachowanych w archiwum wielkich mistrzów krzyżackich, które zgodnie z miejscem jego przechowywania w latach 1722-1944 nosi miano Archiwum królewieckiego (obecnie w Berlinie). Podczas gdy do okresu przed $1410 \mathrm{r}$. liczba jednostek archiwalnych w zespole dokumentów papierowych (Ordensbriefarchiv) sięga półtora tysiąca, to dla okresu następnego, do 1454 r., zbliża się do 12 tys.; do tego należy dodać ok. 1500 dokumentów niedatowanych, odkrytych podczas porządkowania $\operatorname{archiwum}^{26}$ : sporo

s. 41-56; А.И. Груша, Документальная письменность Великого Княжества Литовского (конеи XIV - первая треть XVI в.), Минск 2015.

22 Biskup 1993; V. Almonaitis, Žemaitijos politine padetis 1380-1410 metais, Kaunas 1998; M. Jučas, Žalgirio mūšis, Vilnius 1999; S.C. Rowell, Ne visai primintinos kautynès. Ką byloja šaltiniai apie 1399 m. mūšį ties Vorsklos upe?, „Istorijos šaltinių tyrimai” 1, 2008, s. 67-89; WPL; P.A. Беспалов, Литовско-московские отночения 1392-1408 годов в связи со смоленской, черниговской и рязанской политикой Витовта и Василия I, „Средневековая Русь” 12, 2016, s. 129-182; Kubon 2016. Zauważalną luką w badaniach, którą piszący te słowa spodziewa się wypełnić w przyszłości, pozostają stosunki Witolda z sąsiadami wschodnimi - ziemiami ruskimi i przeżywającą okres kryzysu Złotą Ordą; zob. też G. Mickūnaite, Vytautas Didysis. Valdovo ịvaizdis, Vilnius 2008; Jogailos ir Vytauto laikai. Moksliniu straipsniu rinkinys, skirtas Žalgirio mūšio 600-osioms metinems, Kaunas 2011.

${ }^{23}$ K. Neitmann, Die Staatsverträge des Deutschen Ordens in Preussen 1230-1449. Studien zur Diplomatie eines spätmittelalterlichen Territorialstaates, Köln-Wien 1986 (Neue Forschungen zur Brandenburg-Preussischen Geschichte, t. 6).

${ }^{24}$ Gąsiorowski 2015; Neitmann 1990.

25 Podstawowe publikacje: CEV; Vitoldiana. Liczne edycje przyczynkowe poszczególnych listów i dokumentów wskazane są w itinerarium pod odpowiednimi datami.

26 B. Jähnig, Die Quellen des historischen Staatsarchivs Königsberg zur Geschichte der deutsch-litauischen Beziehungen in der Zeit der Ordensherrschaft und des Herzogtums Preußen, w: Deutschland und Litauen. Bestandsaufnahmen und Aufgaben der historischen Forschung, red. 
z nich udało się datować, czasami nawet na konkretny rok - głównie dzięki pracom badaczy polskich ${ }^{27}$. Większość listów i dokumentów Witolda zachowanych w tym archiwum została opublikowana jeszcze pod koniec XIX w., przede wszystkim przez Antoniego Prochaskę ${ }^{28}$. Przy czym o miejscu pobytu wielkiego księcia można wnioskować nie tylko $\mathrm{z}$ bezpośrednich wskazówek $\mathrm{w}$ datach i miejscach wystawienia jego dokumentów, ale też $\mathrm{z}$ danych pośrednich, czyli np. $\mathrm{z}$ wiadomości o poselstwach krzyżackich do niego. Jeżeli korespondencja dostojników krzyżackich podaje, że poseł był u Witolda, to można $\mathrm{z}$ bardzo dużą dozą prawdopodobieństwa przyjąć, że Witold w tym czasie znajdował się na Litwie właściwej albo w ościennej części Rusi. Archiwum wielkich mistrzów nie zachowało się jednak $\mathrm{w}$ całości ${ }^{29}$ : o niezachowanej części pojęcie daje jego inwentarz ${ }^{30}$, powstały zapewne w pierwszej połowie XVI w., którego materiały dopiero wprowadza się do obiegu naukowego ${ }^{31}$. Listy i dokumenty Witolda zachowały się także w niektórych innych archiwach, np. w archiwum miasta Rygi. Ponieważ Metryka Litewska za Witolda jeszcze nie była prowadzona, pozostaje opierać się na zachowanych oryginałach, późniejszych odpisach i przekazach treści dokumentów tego władcy ${ }^{32}$.

Z nieco trudniejszą sytuacją mamy do czynienia w przypadku tak specyficznego gatunku źródeł, jakimi były księgi wydatków. W Wielkim Księstwie Litewskim epoki Witolda albo wcale ich nie prowadzono, albo się nie zachowały. Niektóre dane o Wielkim Księstwie znajdują się w księgach państw i miast, które utrzymywały z nim kontakty - Królestwa Polskiego, państwa zakonnego, Krakowa

N. Angermann, J. Tauber, Lüneburg 1995, s. 12. Podliczenia wykonano na podstawie RHD. Ogólnego obrazu nie zmienia też ustalenie poprawnej datacji niektórych listów.

27 Dla tego studium najważniejsze są badania S. Jóźwiaka nad wywiadem i kontrwywiadem w stosunkach polsko-litewsko-krzyżackich; Jóźwiak 2004.

${ }^{28}$ CEV. Najpełniejszą informację o oryginałach dokumentów Witolda przytacza w ich studium paleograficznym R. Čapaite, Gotikinis kursyvas...

29 Według oceny K. Kwiatkowskiego, z czasów wojny z lat 1409-1411 zachowało się ok. 15-20\% korespondencji wspólnoty zakonnej; idem, Zakon Niemiecki jako „corporatio militaris”, cz. 1: Korporacja i krag przynależących do niej. Kulturowe i społeczne podstawy działalności militarnej zakonu w Prusach (do początku XV wieku), Toruń 2012 (Dzieje Zakonu Niemieckiego, t. 1), s. 77, przyp. 176.

30 LMAVB RS, F 15-73.

${ }^{31}$ K. Kwiatkowski, Neue Quellen aus dem Kreis des Deutschen Ordens zum Krieg von 1409-1411 (Teil 1), ZH, 75, 2010, nr 4, s. 67-112; Kwiatkowski 2016, s. 343-354. Kilka dokumentów z lat 30. $\mathrm{XV}$ w., zachowanych w tym rękopisie w postaci regestów, opublikowano lub wykorzystano w: С.В. Полехов, Наследники Витовта... (tu błędnie datowałem ten rękopis na koniec XVI lub początek XVII w.).

32 Teksty kilku niedawno odnalezionych dokumentów Witolda wykorzystanych w niniejszym itinerarium (z 24 II 1405, 13 VI 1417, 21 II 1418, 28 i 30 IX 1420, 12 III, 29 VI, 29 VIII i 23 XII 1429) udostępnił piszącemu te słowa dr Tomasz Jaszczołt, któremu pragnę złożyć serdeczne podziękowania. 
i sąsiedniego Kazimierza oraz Rygi ${ }^{33}$. Są to z reguły dane o wysłaniu poselstw na Litwę i przyjęciu posłów jej władcy. Specyfika ksiąg wydatków polega na tym, że nierzadko wpisy nie są chronologiczne, ważniejsze było bowiem odnotowanie faktu wydania pewnej sumy pieniędzy na jakiś cel niż jego dokładnej daty ${ }^{34}$. Dlatego niżej wykorzystano tylko te wpisy z ksiąg wydatków, które udaje się datować. Jeżeli księga skarbnika malborskiego odnotowuje wydatki na przyjęcie posłów Witolda, to można przypuszczać, że władca przebywał na Litwie właściwej oczywiście z pewną dozą umowności, ponieważ poselstwa krzyżackie nierzadko udawały się też do Grodna, gdzie dojeżdżały w ciągu kilku dni ${ }^{35}$, podczas gdy dalsze wyjazdy wielkiego księcia utrudniały wymianę poselstw ${ }^{36}$. Natomiast dane o wysłaniu posłów do Witolda w większości nie są brane pod uwagę, ponieważ nie wiadomo, jak dokładnie osoby ich wysyłające znały miejsce pobytu władcy litewskiego ${ }^{37}$.

Wyniki prac piszącego te słowa nad itinerarium Witolda $z$ lat $1392-1430^{38}$ przedstawione są poniżej w formie tabelarycznej; tamże wyjaśniam zasady opracowania. Żywię nadzieję, że niniejsza publikacja przyczyni się do rozwoju badań nad dziejami Wielkiego Księstwa Litewskiego w końcu XIV i w pierwszym trzydziestoleciu XV w. oraz w systematyzacji danych o tym okresie, odnajdowania i publikacji niewydanych jeszcze źródeł.

${ }_{33}$ RD; Rachunki królewskie z lat 1393-1395 i 1412. Rachunki podrzęctwa krakowskiego. Rachunki stacji nowosadeckiej, wyd. H. Wajs, Warszawa 1993; NKRMK; Krzyżanowski, s. 392-465; Kämmerei-Register der Stadt Riga 1348-1361 und 1405-1474, t. 1: Die Kämmerei-Register, wyd. A. von Bulmerincq, Leipzig 1909.

${ }^{34}$ M. Starzyński, Nad średniowiecznymi księgami rachunkowymi miasta Krakowa, „Roczniki Historyczne” 74, 2008, s. 165-178. W księdze skarbnika malborskiego „konsekwencji chronologicznej przestrzegano tylko w ramach podrozdziałów [za każdy rok - S.P.], i to nie zawsze”, T.Ю. Игошина, Двор верховного магистра Немецкого ордена в Пруссии в коние XIV - начале XV веков, Москва 2000, s. 18, tłum. S.P.

35 Otóż w grudniu 1414 r. list Witolda z Grodna dostarczono wielkiemu mistrzowi, rezydującemu wtedy na północny zachód od Malborka (odległość - ponad $400 \mathrm{~km}$ ), w ciągu $10 \mathrm{dni}$, natomiast zimą 1427 r. poseł krzyżacki przybył z Grodna do Kętrzyna (ponad 200 km) w ciągu 2 dni; CEV 614, 1304.

36 Nie wykluczały jednak całkowicie. W lipcu 1399 r., przebywając u Jagiełły w Krakowie, Witold wysłał do wielkiego mistrza swego pisarza Pietrasza (CEV 201). O tym samym problemie - trudnościach porozumienia się władz zakonnych z królem polskim podczas objazdu Rusi, którego dokonywał wspólnie z Witoldem - zob. niżej, przyp. 265.

37 Niektóre takie przypadki omawiam w przypisach.

38 Cezura początkowa wynika z zasadniczej zmiany charakteru podróży Witolda w 1392 r., gdy stopniowo z księcia dzielnicowego, szukającego przytułku we władztwie zakonu krzyżackiego, staje się on władcą jednego z największych państw Europy Wschodniej. 


\section{Wielki książę litewski - dux ambulans?}

Proponując nową, istotnie uzupełnioną i poprawioną wersję itinerarium Witolda, nie sposób uniknąć odpowiedzi na pytanie: co mówi nam ono o praktyce podróży hospodarskich po Wielkim Księstwie Litewskim? Stosunkowo szczegółowe dane o podróżach władcy w długim okresie pozwalają lepiej zrozumieć charakter takich podróży niż itineraria późniejszych władców, których mobilność wiązała się z wojnami albo objęciem tronu polskiego obok litewskiego. Ponadto itinerarium Witolda pozwala oddzielić nowe cechy w praktyce podróży hospodara po swoim władztwie od tradycyjnych jej elementów.

$\mathrm{W}$ mediewistyce dwudziestowiecznej itinerarium monarchy przekształciło się z prostego wykazu miejsc i dat jego pobytu na rzeczywiste narzędzie badawcze - w znacznym stopniu dzięki opracowaniu kwestionariusza, przede wszystkim przez niemieckich i polskich badaczy. Postawili oni pytania dotyczące funkcji objazdów monarszych w polityce wewnętrznej i zewnętrznej, ich strony gospodarczej, osobliwości dróg, szybkości przemieszczania się władcy, długości jego pobytu w określonych miejscach, podziału państwa na strefy w zależności od częstotliwości i długości pobytu panującego w tej czy innej miejscowości. Niestety w itinerarium Witolda pióra Jerzego Purca pytania te prawie nie znalazły odbicia. Jednak nawet uzupełniona wersja itinerarium ma kilkudniowe i kilkumiesięczne luki, co utrudnia udzielenie wyczerpujących odpowiedzi na powyższe pytania.

W literaturze zwykle podkreśla się „objazdowy” charakter władzy wielkich książąt litewskich, ale bez dogłębnej analizy istniejących danych - zapewne według analogii z sąsiednią Polską. Na przykład Antoni Gąsiorowski, rozpatrując fenomen wielkich objazdów Jagiełły, stwierdza: „Formułę tak aktywnych objazdów kraju być może częściowo przeniósł Jagiełło z Litwy" ${ }^{39}$. Podaje jednak także, że system regularnych objazdów królewskich w Koronie ustalił się dopiero na przełomie wieków, po śmierci Jadwigi - wydarzenie to wywołało kryzys legitymacji władzy królewskiej Jagiełły ${ }^{40}$ - i stabilizacji stosunków z Witoldem. Wcześniej bowiem podróże Jagiełły służyły załatwieniu bieżących spraw ${ }^{41}$. Rimvydas Petrauskas określa Witoldową formę rządzenia przy pomocy formuły stworzonej przez Klausa Neitmanna dla zakonu krzyżackiego w Prusach: „rządzenie rezydencyjne po drodze” („Residenzherrschaft unterwegs”) ${ }^{42}$. Szczegółowo wypowiedział się na ten temat Aleksander Hrusza:

\footnotetext{
39 Gąsiorowski 2015, s. 20.

${ }^{40}$ W. Fałkowski, Monarchia $w$ poszukiwaniu nowego status quo. Sytuacja polityczna w Koronie przed uniq horodelska, 1399-1413, „Prace Historyczne” 141, 2014, nr 2: Unia horodelska 1413, s. 195-220 (o objazdach Królestwa Polskiego s. 205).

${ }^{41}$ Gąsiorowski 2015, s. 17-18.

42 R. Petrauskas, Didžiojo kunigaikščio institucinio dvaro susiformavimas..., s. 21.
} 
Государственная власть в период её функционирования в конце XIV - первой трети XV в. наиболее чётко выразила приоритеты рациональных нововведений перед религиозной традицией. В связи с этим укажем на одно условие появления документа. Это - изменение в системе управления государством: смена прямого управления правителя управлением через его посредников, сидящих „на господарском местце” - наместников-державцев, старост, воевод, сложение административной системы на местах. В её результате произошло постепенное прекращение целенаправленных объездов правителя подвластных ему земель с целью выполнения судебно-административных функций. Подчеркнём, что в данном случае речь идёт о целенаправленных объездах, а не вынужденных поездках правителя (например, военных походах, во время которых он мог выполнять указанные функции $)^{43}$.

Ta opinia wywołuje istotne pytanie: jakie miejsce w przywołanym schemacie zajmują książęta dzielnicowi XIV w. - czy ich księstwa znajdowały się „pod bezpośrednimi rządami władcy” („под прямым управлением правителя”)? Vytautas Volungevičius, powołując się na uniwersalny charakter objazdów monarszych jako formy rządzenia i zarządu ${ }^{44}$, i szczególnie jaskrawe przykłady podróży Witolda i Jagiełły po Wielkim Księstwie Litewskim, ogranicza się do stwierdzenia: „Na terytoriach ruskich Wielkiego Księstwa Litewskiego działał taki sam model rządów objazdowych [jak i na Litwie właściwej - S.P.]. Można mówić jedynie o częstotliwości i długości tego typu podróży"45. Ale dobrze wiadomo, że w różnych krajach mobilność monarsza przybierała różne formy - od Świętego Cesarstwa Rzymskiego, często zwanego „imperium bez stolicy”46, do Francji, której królowie

43 А.И. Груша, Документальная письменность Великого княжества Литовского..., s. 107 (dalej w przypisie autor proponuje porównać itineraria Witolda oraz Aleksandra Jagiellończyka i Zygmunta Starego). Właściwie nie zmienił też zdania w nowym, poprawionym i uzupełnionym wydaniu tej książki: Кризис доверия? Появление и утверждение правового документа в Великом княжестве Литовском (конеи XIV - первая треть XVI в.), Москва-Санкт-Петербург 2019, s. 125-126.

${ }^{44}$ H.C. Peyer, Das Reisekönigtum des Mittelalters, „Vierteljahrschrift für Sozial- und Wirtschaftsgeschichte" 51, 1964, s. 1-21; por. też I. Hlaváček, Höfe - Residenzen - Itinerare, Prag 2011 (wybór prac); Полюдье: всемирно-историческое явление, red. Ю.М. Кобищанов, Москва 2009; о sytuacji na Rusi zob. zwł. П.С. Стефанович, История полюдья в средневековой Руси (X-XVI вв.), „Российская история” 2017, nr 6, s. 3-13 (tu uderza brak odniesień do przykładów i literatury z Zachodu); zob. też D. Dąbrowski, Książę w drodze. O mobilności Rurykowiczów w XIII w. na przykładzie Daniela Romanowicza. Klasyfikacja podróży, „Slavia Orientalis” 64, 2015, nr 1, s. 7-34; idem, Książę w drodze. Warunki podróżowania Rurykowiczów w XIII w. na przykładzie Daniela Romanowicza, „Slavia Orientalis” 64, 2015, nr 2, s. 207-227.

45 V. Volungevičius, Pilies šešèlyje. Teritorija, visuomenè ir valdžia Lietuvos Didžiojoje Kunigaikšstystèje, Vilnius 2015, s. 77, 87 (tłum. S.P.).

46 W. Berges, Das Reich ohne Hauptstadt, w: Das Hauptstadtproblem in der Geschichte. Festgabe zum 90. Geburtstag Friedrich Meineckes, gewidmet vom Friedrich-Meinecke-Institut an der Freien Universität Berlin, Tübingen 1952 (Jahrbuch für Geschichte des Deutschen Ostens, t. 1), s. 1-30; K.O. von Aretin, Das Reich ohne Hauptstadt? Die Multizentralität der Hauptstadtfunktionen im Reich bis 1806, w: Hauptstädte in europäischen Nationalstaaten, red. Th. Schieder, G. Brunn, München-Wien 1983 (Studien zur Geschichte des neunzehnten Jahrhunderts, t. 19), s. 5-13. 
spędzali większość czasu w historycznym centrum państwa ${ }^{47}$; to właśnie „częstotliwość i długość podróży”, wskaźniki ilościowe, nadawały systemowi rządów te lub inne cechy jakościowe. Dla ich ustalenia niezbędna jest specjalna analiza źródeł dotyczących Wielkiego Księstwa Litewskiego. I zacząć trzeba od systematycznych danych o podróżach Witolda.

Już przy pobieżnej analizie przytoczonego poniżej itinerarium nie sposób nie zauważyć pewnych prawidłowości. Po pierwsze, to nierównomierność informacji na temat miejsca pobytu władcy: dla drugiej połowy rządów mamy ich więcej podczas gdy dla $1395 \mathrm{r}$. udało się zrobić tylko trzy wpisy, to dla okresu po $1409 \mathrm{r}$. mamy co najmniej 10 wpisów niemal w każdym roku - z wyjątkiem lat 1419 i 1423. Po drugie, znaczna liczba miejsc problematycznych wynika $z$ charakteru źródeł: nierzadko dla tej samej wiadomości da się zaproponować dwie, trzy albo nawet więcej wersji datacji. Tym niemniej rozkład ilościowy danych wskazuje, że większość czasu litewski władca spędzał na Litwie właściwej - w historycznym i politycznym centrum państwa, z którym sąsiadowały posiadłości Kiejstuta na Rusi. W „węższym itinerarium” Witolda - wykorzystując termin zaproponowany przez Adolfa Gauerta (das engere Itinerar) ${ }^{48}$ - przeważają Wilno, Troki, Nowogródek, Grodno, Kowno oraz dwory hospodarskie położone w południowej części dzisiejszych Litwy i północnej części Białorusi ${ }^{49}$. Tutaj budowano zamki ${ }^{50}$ i dwory hospodarskie, które sam Witold nie raz określał jako „nowe” ${ }^{51}$. Pośrednie dane o miejscach jego pobytu można znaleźć w jego korespondencji i wymianie poselstw z dostojnikami zakonu krzyżackiego. Jest to zwłaszcza aktualne dla końca

${ }^{47}$ H.C. Peyer, op. cit., s. 4-6; A. Gąsiorowski, I. Skierska, op. cit., s. 69.

48 A. Gauert, Zum Itinerar Karls des Großen, w: Karl der Große. Lebenswerk und Nachleben, t. 1: Persönlichkeit und Geschichte, red. H. Beumann, Düsseldorf 1967, s. 307-321.

${ }^{49}$ Zob. itinerarium Witolda i indeksy do niego. E. Gudavičius określa „areał rezydowania władcy” jako trójkąt Kowno - Wilno/Miedniki - Grodno, ale z ważnym zastrzeżeniem: „odrzuciwszy ziemie ruskie i punkty pograniczne nad Niemnem i w Brasławiu” (E. Gudavičius, Miestu atsiradimas Lietuvoje, Vilnius 1991, s. 49-51; tłum. S.P.). To wyklucza z analizy Nowogródek, jedną z najważniejszych rezydencji Witolda, $w$ dodatku położoną na Litwie właściwej, o czym świadczy jego określenie we współczesnych źródłach - Nowogródek Litewski; zob. np. KDKW 100; CEV 1330, 1361. Według T. Baranauskasa: „próby oceny najważniejszych centrów trzynastowiecznego państwa litewskiego na podstawie źródeł piętnastowiecznych są skazane na niepowodzenie”. Badacz ten lokalizuje podstawowe centra królestwa Mendogowego na północ, północny zachód i północny wschód od Wilna, m.in. na Żmudzi; idem, Lietuvos valstybès ištakos, Vilnius 2000, s. 192-203, cyt. ze s. 203, thum. S.P.

50 Podstawowe prace: Z. Ivinskis, op. cit.; Lietuvos pilys, red. J. Jurginis, Vilnius 1971; A. Baliulis, S. Mikulionis, A. Miškinis, Trakų miestas ir pilys. Istorija ir architektūra, Vilnius 1991; N. Kitkauskas, Vilniaus pilys: istorija, statyba, architektūra, Vilnius 2012; А.М. Кушнярэвіч, Мураваная дабастыённая фартыфбікацыя Вялікага Княства Літоўскага, Мінск 2014; М. Волкаў, Архітэктура Старога замка часоў Вітаўта ў Гародні, „Беларускі гістарычны часопіс” 2014, nr 2, s. 17-34; V. Volungevičius, op. cit.

${ }^{51}$ Na przykład Worany (Orany) - w latach 1413-1414 (CEV 519, 588), Dowgi (Daugi) - w 1415 r. (CEV 617, 618), Rudominę - w 1422 r. (CEV 1010), Brasław - w 1426 r. (CEV 1216). 
XIV w., ponieważ w tym czasie mamy niewiele szczegółowych świadectw bezpośrednich. Ponieważ zarówno Witold, jak i władze zakonne byli zainteresowani zbliżeniem, ich kontakty w tym czasie były dość regularne, natomiast przerwy można wytłumaczyć nieobecnością Witolda na Litwie właściwej w związku z realizacją jego polityki wschodniej ${ }^{52}$. Sąsiedzi Wielkiego Księstwa obecność Witolda na Litwie właściwej uznawali za zwyczaj i - wychodząc z tego założenia - kierowali tam swoje listy i poselstwa. Gdy pod koniec $1396 \mathrm{r}$. Witold zaproponował wielkiemu mistrzowi krzyżackiemu wysłanie poselstwa do Łucka albo Brześcia, ten odpowiedział, że od dawna nie ma zwyczaju posyłania posłów tak daleko w głąb państwa litewskiego ${ }^{53}$. Natomiast 10 września 1402 r. ten sam dostojnik skarżył się, że nie otrzymuje od Witolda odpowiedzi na swoje listy i nie wie, gdzie ów przebywa ${ }^{54}$. Podobny przypadek przydarzył się w 1424 r. posłom pskowskim: gdy przyjechali na Litwę (właściwą), to okazało się, że wielki książę jest na Wołyniu, udali się więc tam, aby zabiegać o jego przychylność ${ }^{55}$. $Z$ drugiej strony, udając się w podróż i chcąc pokazać władzom zakonnym przyjacielskie nastawienie, Witold często szczegółowo informował wielkiego mistrza o planie swoich podróży, aby ten wiedział, gdzie i kiedy może skierować poselstwo ${ }^{56}$. Do Witolda na Litwę właściwą i ościenne tereny jeździli nie tylko posłowie państw sąsiednich, lecz także jego poddani, np. Połocczanie - aby zabiegać o jego przychylność i wstawiennictwo ${ }^{57}$. Obecność Witolda na Litwie właściwej była zatem oczywista nie tylko dla dostojników krzyżackich, ale też dla jego poddanych, którzy wiedzieli również, gdzie książę przebywa w określonym momencie. Wyraźnie świadczą o tym źródła późniejsze: w 1469 r. Połocczanie, dowiedziawszy się o przyjeździe Kazimierza Jagiellończyka do Wielkiego Księstwa Litewskiego, zaprosili do niego Ryżan, z którymi wtedy byli w konflikcie ${ }^{58}$; w 1520 r. Zygmunt Stary wyznaczył mińskiej szlachcie termin stawienia się na rozprawę sądową „въ чотырехъ неделяхъ [...] гдъ нас послышать" ${ }^{59}$. Dla mieszkańców Wielkiego Księstwa nie było tajemnicą, że aby rozwiązać tę lub inną kwestię na swoją korzyść nie warto czekać na przyjazd hospodara do ich ziemi, lepiej udać się do niego, pomimo długości i kosztów podróży. Niemniej, jak pokazują opisy Witoldowych objazdów

52 Kubon 2016, s. 89-90.

${ }^{53}$ CDP VI 29.

${ }^{54}$ CEV 259. Według Antanasa Vasiliauskasa list z Wilna do Malborka docierał w ciągu 3-4 dni; LMAVB RS, F 205-22, s. 5, cyt. za: R. Čapaite, Istorikas Antanas Vasiliauskas (Vasys) (1902-1974), „Mūsų praeitis” 2, 1992, s. 72.

${ }^{55}$ ПЛ II, s. 39-40.

${ }^{56}$ CEV 1159.

57 ПГ І 46.

58 ПГ І 189.

59 Русская историческая библиотека, t. 20: Литовская метрика, сz. 1, Петербург 1903, nr [III].159, s. 1479. Za wskazanie tego źródła pragnę podziękować dr. hab. Aleksandrowi I. Hruszy (Mińsk). 
wschodnich i południowych ziem państwa litewskiego, jego pojawienie się przed poddanymi w "dalekich ziemiach ruskich” zachowywało znaczenie jako sposób komunikacji i utwierdzenia władzy monarchy ${ }^{60}$.

Niezależnie od oceny statusu ziemi grodzieńskiej w XIV-XV w. ${ }^{61}$, Grodno zajmowało trzecie miejsce po Wilnie i Trokach w systemie rezydencji Witolda. Miasto to było jednym z głównych ośrodków we władztwie Kiejstuta i Witolda ${ }^{62}$ : pierwszy z nich być może zawarł tam układ z księciem mazowieckim Siemowitem III (jeżeli uważać, że datum zachowanego egzemplarza sięga pierwotnego dokumentu autentycznego) ${ }^{63}$, natomiast drugi w latach 1389-1392 wykorzystywał pieczęć konną z napisem „Pieczęć Witolda, księcia litewskiego i pana grodzieńskiego"64. Na początku 1393 r. Krzyżacy, korzystając z tego, że Witold był zajęty walką z Korybutem, spalili tamtejszy zamek, po powrocie z wyprawy Witold odbudował go, ale wkrótce zamek znów został spalony ${ }^{65}$. Zapewne niedługo warownię ponownie odbudowano, skoro w styczniu $1397 \mathrm{r}$. Witold zamierzał przyjąć w Grodnie poselstwo krzyżackie, a w kwietniu 1398 r. tam odbył się zjazd Witolda z wielkim mistrzem krzyżackim. Niedługo po zjeździe salińskim w $1398 \mathrm{r}$. zamek znowu spłonął ${ }^{66}$ i raz jeszcze został odbudowany - zapewne przed 1401 r., ponieważ gdy wybuchła kolejna wojna z zakonem Grodno było jednym z celów wyprawy krzyżackiej w 1402 r. Wiadomo, że Witold nie raz bywał w Grodnie w pierwszych latach swoich rządów, natomiast od 1409 r. - czyli w tym okresie, gdy dane o miejscach jego pobytu stają się systematyczne - jego pobyty tam poświadczone są corocznie. Przerwy w latach 1412-1413 i 1420-1423 z dużą dozą prawdopodobieństwa spowodowane są objętością zachowanych źródeł: $\mathrm{w}$ tych

${ }^{60}$ Zob. przede wszystkim CEV 1298, 1329 oraz dane o dokumentach, które Witold wystawił dla swoich poddanych podczas podróży na południe Wielkiego Księstwa w latach 1424 i 1427.

${ }^{61}$ Może już w drugiej połowie XIV w. ziemia grodzieńska uchodziła za część Litwy; В.Л. Насевiч, Літва у XIV cm., „Беларуская даўніна” 3, 2016, s. 9-10; А.У. Ліцкевіч, Гародня і Гарадзенскі рэгіён у другой палове XIII-XIV cmcm. Назва і межы, „Гарадзенскі палімпсест” 2012, [2013], s. 12-13; por. E. Gudavičius, Rec.: Jerzy Ochmański. Litewska granica etniczna na wschodzie od epoki plemiennej do XVI wieku..., LIM, 1982 [1983], s. 118.

${ }^{62}$ Szerzej zob. J. Tęgowski, Rola Grodna w składzie Wielkiego Księstwa Litewskiego w XIV i początkach XV wieku, w: Гарадзенскі палімпсест 2012. Людзі даўняй Гародні. XV-XX стст., red. А.Ф. Смаленчука, Н.У. Сліж, Гродна 2013, s. 65-67. Chodzi o grodzieński zamek górny; А.У. Ліцкевіч, Гародня і Гарадзенскі рэгіён у другой палове XIII-XIV cmcm. Сухапутныя і водныя камунікацы і, населеныя пункты, этнаканфесійны склад і міграцыь насельніцтва, „Arche” 2014, nr 11: Гарадзенскі міленіум, s. 35. O ziemi grodzieńskiej zob. idem, Гародня і Гарадзенскі рэгіён у другой палове XIII-XIV cmcm. Назва і межы..., s. 10-59 (tamże wсzеśniejsza literatura).

${ }^{63}$ Nowy kodeks dyplomatyczny Mazowsza, cz. 3: Dokumenty z lat 1356-1381, wyd. I. Sułkowska-Kuraś, S. Kuraś, Warszawa 2000, nr 24.

${ }^{64}$ E. Rimša, Lietuvos didžiojo kunigaikščio Vytauto antspaudai ir žemiu heraldika, Vilnius 2016, s. 89-97.

65 SRP II, s. 650-651; SRP III, s. 623-624.

${ }^{66}$ SRP III, s. 224. 
latach Witold jeździł z Wilna i Trok na południe i z powrotem, dlatego byłoby dziwne, gdyby podczas tych przejazdów omijał Grodno. Wydaje się nieprzypadkowe, że w 1419 r., gdy wielki pożar zniszczył wileńskie zabudowania zamkowe, Witold przeniósł się właśnie do Grodna. Jednocześnie zamek grodzieński, gdzie władca osiadł na długo, wymagał naprawy i rozbudowy: do tych prac zostali sprowadzeni mieszkańcy Merecza, Przełajów i okolic ${ }^{67}$. Świadczy to o niższym miejscu Grodna w hierarchii rezydencji Witolda w porównaniu z Wilnem i Trokami.

Poza Litwą właściwą Witold najczęściej odwiedzał południowe regiony Wielkiego Księstwa: Podlasie, Brześć i Wołyń, który ze swoimi potężnymi zamkami służył jako punkt oparcia władzy wielkiego księcia w południowej części jego państwa. Rzadziej udawał się na Kijowszczyznę i inne południowe ziemie Wielkiego Księstwa, m.in. Podole. Tam konsekwentnie usiłował umocnić swoją pozycję, zachodnią część tego regionu Jagiełło przekazał mu bowiem w dożywocie w $1411 \mathrm{r}^{68}$ Wiele wizyt Witolda na południu znanych jest tylko z przypadkowych wzmianek albo rekonstruowanych hipotetycznie (w latach $1410-\mathrm{z}$ dużą dozą prawdopodobieństwa, 1413, 1414, 1418 lub 1419, 1427), ale już informacje sprawdzone wystarczą, by postawić wniosek o wadze tego kierunku. Praktycznie wszystkie te wizyty związane były z konkretnymi celami polityki, zarówno wewnętrznej, jak i zagranicznej. Do tych ostatnich należą wyprawy wojskowe i spotkania $\mathrm{z}$ władcami sąsiednich państw - królem polskim Władysławem II Jagiełłą, chanami Złotej Ordy itd., a najbardziej jaskrawe przykłady stanowią zjazdy władców w Kijowie w 1411 r. ${ }^{69} \mathrm{i}$ w Łucku w 1429 r. Chociaż Brześć należał do „ojcowizny” Witolda, w tej części swego władztwa bywał on znacznie rzadziej niż na Litwie właściwej: prawie wszystkie jego znane wizyty w sąsiadującym $\mathrm{z}$ nią Brześciu związane były z podróżami na Wołyń albo ze spotkaniem z królem polskim jadącym na Litwę.

Znacznie mniej danych zachowało się o podróżach Witolda do wschodniej części jego władztwa - Połocka $(1399,1426)^{70}$, Witebska $(1393,1413,1426)$,

${ }^{67}$ CEV 828, 840: Rusin mieszkający 6 mil na południe od Grodna poinformował komtura Renu, „wi dis land czu Mirken und von Perlewen und ouch von Garten, das die alsampt legen tzu Garten und aldo am huze buwen und bessern".

68 В. Михайловський, Західне Поділля під володінням Вітовта у 1411-1430 роках. Надавча політика у світлі документів, w: До джерел. Збірник наукових праць на пошану Олега Купчинського з нагоди його 70-річчя, t. 2, Київ-Львів 2004, s. 110-128; idem, Podole po Grunwaldzie (1410-1430). Walka Witolda z Jagiełta, w: Jogailos ir Vytauto laikai..., s. 117-125; J. Kurtyka, Podole $w$ średniowieczu i okresie nowożytnym. Obrotowe przedmurze na pograniczu cywilizacji, w: idem, Podole w czasach jagiellońskich, Kraków 2011, s. 124-128.

69 Zob. о nim: Mikulski 2011, s. 81-89; С.В. Полехов, Лугвень, Новгород и восточная политика Витовта (1411-1414) в свете малоизвестных источников Кёнигсбергского архива, w: Мсціслаў і Мсціслаўскі край, Мінск 2019, s. 73-74.

70 Tego ogólnego obrazu nie zmieniają wiadomości o pobycie Witolda pod koniec któregoś roku na przełomie wieków, na razie nie da się ich bowiem dokładnie datować; HUB V 358; LVVA, f. 673, apr. 4, k. 18, nr 114; ПГ І 30, 31. 
Smoleńska $(1392,1395,1396,1399,1404,1423,1427)$ oraz do ziem czernihowskich znajdujących się pod władzą książąt dzielnicowych (1427). Znane wizyty tam były w znacznej mierze związane $\mathrm{z}$ wyprawami wojennymi, których celem było podporządkowanie ziem Wielkiego Księstwa Litewskiego władzy Witolda, lub też z jego stosunkami $\mathrm{z}$ wielkimi książętami moskiewskimi ${ }^{71}$. Wreszcie, pomimo sąsiedztwa Żmudzi z Litwą właściwą i jej określania przez Witolda jako „ojcowizny"72, poza jego podróżami do Jurborka (Georgenburga) na spotkania z wielkim mistrzem dokładnie znana jest tylko jedna jego „pokojowa” wizyta w tej ziemi jesienią 1417 r., gdy odbywał się chrzest Żmudzinów. W latach 1400 i 1405 Witold brał bowiem udział w wyprawach, których celem było podporządkowanie Żmudzi władzy zakonu. Nawet po zawarciu z nim „wieczystego pokoju” w 1411 r., na mocy którego Żmudź uznana została za dożywocie Jagiełły i Witolda, władcy ci nie udali się $\operatorname{tam}^{73}$. Natomiast skala ich podróży „misyjnej” jesienią 1413 r. została znacznie przeceniona przez Długosza, jeżeli w ogóle podróż ta miała miejsce ${ }^{74}$. Tak samo jak w imperium Karola Wielkiego lub w Świętym Cesarstwie Rzymskim Ottona I (962-973) i Konrada II (1024-1039), których praktyka rządzenia objazdowego jest dobrze zbadana, w Wielkim Księstwie Litewskim Witolda da się wydzielić centralny (bazowy) obszar polityczny, gdzie władca był systematycznie obecny (Litwa właściwa i sąsiadująca z nią część Rusi), oraz obszar, na którym zjawiał się jedynie sporadycznie ${ }^{75}$. Sam Witold nazywał południową i wschodnią część swego władztwa „dalekimi ziemiami ruskimi” $(1424,1427)^{76}$, siedem dekad później w dokumencie Aleksandra Jagiellończyka zostaną one nazwane вкраинами ${ }^{77}$. Dla poddanych wielkich książąt litewskich takie dalekie podróże ich władców były rzadkością, dlatego służyły jako wygodny orientacyjny punkt chronologiczny $^{78}$ : np. w dokumentach piętnastowiecznych spotykamy skojarzenie

71 Spotkania z nimi w Smoleńsku, próby utwierdzenia Witoldowych pozycji na Rusi po śmierci Wasyla I zob. Д.И. Иванов, Московско-литовские отночения в 20-е годы XV столетия, „Средневековая Русь” 2, 1999, s. 79-115.

72 Na przykład w $1420 \mathrm{r}$. Witold skarżył się przybywającym na jego dwór „,rycerzom i knechtom” na Zygmunta Luksemburskiego, że ten oddał zakonowi krzyżackiemu Żmudź - „seyne [Witoldową - S.P.] veterlich erben", GStAPK, OBA 3330.

73 R. Petrauskas, Iki ir po didžiojo mūšio. Politiniai pokyčiai Rytų Pabaltijyje Žalgirio mūšio epochoje, w: Jogailos ir Vytauto laikai..., s. 19-20.

74 D. Baronas, S.C. Rowell, The Conversion of Lithuania. From Pagan Barbarians to Late Medieval Christians, Vilnius 2015, s. 342-347.

75 E. Müller-Mertens, Die Reichsstruktur im Spiegel der Herrschaftspraxis Ottos des Grossen, Berlin 1980 (Forschungen zur mittelalterlichen Geschichte, t. 25); E. Müller-Mertens, W. Huschner, Reichsintegration im Spiegel der Herrschaftspraxis Kaiser Konrads II., Weimar 1992 (Forschungen zur mittelalterlichen Geschichte, t. 35); A. Gąsiorowski, I. Skierska, op. cit., s. 69.

76 CEV 1159, 1298.

77 LM VI, nr 318, s. 208.

78 Por. analogiczne przykłady w dokumentach Rusi północno-wschodniej: Акты социально-экономической истории Северо-Восточной Руси конца XIV - начала XVI в., t. 1, red. Б.Д. Греков, 
wydarzeń z wyjazdem Witolda do Staroduba $(1427)^{79}$, wyprawami Zygmunta Kiejstutowicza na Mścisław (1433) ${ }^{80}$ i Kazimierza Jagiellończyka na Briańsk (1449) ${ }^{81}$; natomiast pewien Połocczanin odnotował w graffiti słynnej cerkwi Spaskiej nie tylko zgon Kazimierza i objęcie władzy przez Aleksandra w 1492 r., ale też wizytę tego ostatniego w Połocku w 1497 r. ${ }^{82}$ Choć w początkach XV w. korespondencja władcy z jego poddanymi już osiągnęła wysoki poziom rozwoju i było wiadomo, gdzie znajduje się Witold podczas objazdów kraju, to jednak objazdy te mogły być też poważną przeszkodą dla tego typu komunikacji. W liście z 9 marca 1419 r., pisanym ze Słonimia, Witold przepraszał bowiem wielkiego mistrza, że długo nie odpowiadał na jego listy, ponieważ znajdował się „daleko w naszych ziemiach ruskich"83.

Przytoczone dane pokazują, że w Wielkim Księstwie Litewskim za Witolda nie ukształtował się system regularnych objazdów państwa podobny do polskiego. Nieprzypadkowo w 1424 r. wielki książę pisał do wielkiego mistrza o zamiarze udania się do swoich „dalekich ziem ruskich”, aby obejrzeć zamki, niektórych bowiem nigdy nie widział ${ }^{84}$. Wyjazdy Witolda do jego oddalonych posiadłości spowodowane były koniecznością podjęcia konkretnych zadań z zakresu polityki wewnętrznej i zagranicznej. Bodajże jedynym mniej lub więcej stałym elementem była tradycja zimowego polowania władcy na Litwie właściwej, zauważona przez współczesnych ${ }^{85}$, chociaż nie brakowało wyjątków: wiadomo, że Witold był w Połocku w styczniu 1399 r. oraz w grudniu któregoś roku na przełomie stuleci ${ }^{86}$.

Opisany system w ogólnych zarysach przetrwał też niedługo po śmierci Witolda. Dość szczegółowe (dzięki intensywności kontaktów z zakonem) itinerarium

Москва 1952, nr 29, s. 41; t. 2, орrac. И.А. Голубцов, red. Л.В. Черепнин, Москва 1958, $\mathrm{nr}$ 435, s. 479; Акты феодального землевладения и хозяйства XIV-XVI веков, cz. 1, oprac. С.В. Бахрушин, Л.В. Черепнин, Москва 1951, nr 273, s. 204-205; Е.Л. Конявская, Хронологические вехи и расчеты в древнерусских летописях и актах, w: Русь, Россия: Средневековве и Новое время, t. 4: Четвёртые чтения памяти академика РАН Л.В. Милова. Материаль $\kappa$ международной научной конферениии, Москва, 26 октября - 1 ноября 2015 г., Москва 2015, s. 133-138.

79 AS III 23.

${ }^{80}$ LMAVB RS, F 37-799.

${ }^{81}$ LM VI, nr 315, s. 206.

82 Publ.: І.Л. Калечыц, Эпиграбіка Беларусі X-XIV cmcm., Мінск 2011, s. 120, 222; И.3. Залилов, Графбити Спасо-Преображенской церкви в Полоцке XII-XVII вв., Полоцк 2014, s. 33, tabl. XIV. O wizycie Aleksandra w Połocku w kwietniu 1497 r. zob. K. Pietkiewicz, op. cit., s. 62; ПГ І $341-343$.

${ }^{83}$ CEV 826 (tłum. S.P.).

${ }^{84}$ CEV 1159.

${ }^{85}$ Klimas 1933, s. 153-154; Dług. X-XI, s. 43-45.

${ }^{86}$ HUB V 358. Por. w liście kupców niemieckich do władz Rygi z Połocka, datowanym 24 grudnia bez wskazania roku: „Item so duchte uns wol gud, dat gy deme koninge screvet enen bref, wente he is nu wonaftich hirbynnen", LVVA, f. 673, apr. 4, k. 18, nr 114. 
Świdrygiełły z lat $1430-1432$ pokazuje, że i on podróżował pomiędzy zamkami i dworami na Litwie właściwej, a dłuższe wyjazdy spowodowane były tzw. wojną łucką latem $1431 \mathrm{r}$. i niedoszłym zjazdem polsko-litewskim na początku $1432 \mathrm{r}$. W okresie wojny z Zygmuntem Kiejstutowiczem przemieszczenia Świdrygiełły podporządkowane były logice działań wojennych i konieczności utwierdzania jego władzy na kontrolowanych ziemiach, np. w Kijowie pod koniec 1433 r. po ścięciu wojewody kijowskiego Michała Holszańskiego. Natomiast Zygmunt większość czasu spędzał na Litwie właściwej i nie był skłonny do dalekich podróży: bodajże jedynym wyjątkiem była jego wyprawa na Mścisław jesienią $1433 \mathrm{r} .{ }^{87} \mathrm{Za}$ Kazimierza Jagiellończyka utrwaliły się rządy rezydencjonalne - zarówno w Wielkim Księstwie, jak i w Polsce, przy tym jednoczesne zajęcie dwóch tronów przez tego samego monarchę komplikowało sytuację $e^{88}$ : Kazimierz musiał zabiegać o kompromis zarówno z litewskimi panami, jak i z polskimi możnowładcami, którzy żądali jego stałego pobytu - odpowiednio - na Litwie ${ }^{89}$ i w Polsce $^{90}$.

Aby zrozumieć genezę podróży Witolda po jego władztwie, warto zwrócić się do pradziejów tej praktyki. System ten nie ukształtował się bowiem od razu. Już za Mendoga sposób rządzenia opierał się na podróżach władcy i jego otoczenia po podległych mu obszarach, podczas których zużywano zapasy żywności, jak też poświadczano i utwierdzano władzę króla litewskiego. W 1254 r. biskup litewski Chrystian, przekazując zakonowi krzyżackiemu ziemie na Żmudzi, wcześniej nadane biskupstwu przez Mendoga, pozostawiał sobie prawo corocznych wizytacji tamtejszych kościołów, podczas których zakon miał zaopatrywać go i towarzyszące mu osoby we wszystkie potrzebne rzeczy; przy czym pośrednio określono ich liczebność, ponieważ odnotowano, że biskup może przyjeżdżać tam z 12, a archidiakon - z 7 końmi ${ }^{91}$. W 1263 r. Dowmont, wróciwszy z wyprawy na Romana Briańskiego na Litwę, „погна вборзъ, изогна Миндовга"92, a więc ten

87 С.В. Полехов, Наследники Витовта..., s. 541-557 (itineraria Świdrygiełły i Zygmunta Kiejstutowicza). 19 XII 1433 r. wielki mistrz pisał do Zygmunta, że po zawarciu rozejmu jasinieckiego wysłał do niego z królewskim pokojowcem Mikołajem Zakrzewskim swojego posła Hansa Vochsa, ale ten zatrzymał się w Ragnecie ze względu na chorobę oczu, zwłaszcza, że dowiedział się, iż Zygmunt znajduje się poza Litwą: „das euwer irluchtikeyt nicht inheymisch were”, GStAPK, OF 13, s. 20-21. Itinerarium Świdrygiełły można uzupełnić wzmianką o jego pobycie w Kijowie 10 I 1438 r.; RGADA, f. 389, op. 1, kn. 207, k. 15.

88 A. Gąsiorowski, Podróże panującego..., s. 53-58.

89 Dług. XII, s. 258-259, 353; por. С.В. Полехов, Литовская Русь в XV в. Единая или разделённая? (На материале конфликтов между русскими землями Великого княжества Литовского и государственным центром), w: Древняя Русь после Древней Руси. Дискурс восточнославянского (не)единства, Москва 2017, s. 84-86.

90 Wiosną 1460 r. w Prusach mówiono, że król chciał udać się na Litwę, ale Polacy nie chcieli go wypuścić: „der konigk woldt in Litawen, das woltenn im die Polen nicht gestatten”, LMAVB RS, F 15-73, s. 432.

${ }_{91}$ LUB I 266; Lietuvos istorija, t. 3, Vilnius 2012, s. 310, 367.

92 ПСРЛ II, kol. 860. 
ostatni znajdował się w drodze, czyli objeżdżał swoje władztwo ${ }^{93}$. Przypuszczenie, że władca podróżował po swoich ziemiach $z$ orszakiem staje się jeszcze bardziej prawdopodobne w świetle retrospekcji i danych porównawczych. Ze źródeł szesnastowiecznych dowiadujemy się o istnieniu „posiedzi”, która w tym czasie stanowiła już opłatę w żywności albo pieniężną na rzecz namiestnika wielkoksiążęcego ${ }^{94}$. Edvardas Gudavičius uzasadnił odniesienie uczt, z których wyrosła „posiedź”, do czasów Mendoga, w każdym razie nie później niż na przełom XIII i XIV w. ${ }^{95}$ Zauważono, że u trzynastowiecznych Bałtów (jak zresztą i u innych ludów „barbarzyńskich”96) uczta odgrywała znaczną rolę jako element komunikacji społecznej i politycznej. Rola ta częściowo zachowała się też później: jeszcze w XVI w. w uczcie, która w źródłach pochodzących z Wielkiego Księstwa Litewskiego występuje pod nazwą „piwo”, brali udział przedstawiciele różnych warstw społecznych, przy jednym stole siedzieli szlachcice i ich poddani ${ }^{97}$. Niezależnie od tego, jak datować powstanie „posiedzi” w jej początkowym znaczeniu (od czasownika sédèti - por. starorus. cuдrımu, ros. cuдems, pol. siedzieć), jej przekształcenie miało nastąpić przed przełomem XIV i XV w. Wskazuje na to zachowanie nazwy litewskiej, której nie zastąpiło ani ruskie „poludzie” (na co słusznie wskazuje Gudavičius), ani łacińskie „stacje”. Istnienie „posiedzi” właśnie na Żmudzi i w sąsiadujących z nią na wschodzie powiatach można tłumaczyć zarówno niejednolitą strukturą wczesnego państwa litewskiego, jak i archaizmem miejscowego społeczeństwa w pierwszej połowie XVI w. Podróżom władcy po jego państwie sprzyjały także jego stosunkowo niewielkie rozmiary (w porównaniu z Wielkim Księstwem Litewskim w XIV-XV w.). Niewykluczone, że we władztwie Mendoga w ogóle nie było stolicy ${ }^{98}$ - nawet przy umowności tego pojęcia dla epoki, gdy nie istniały jeszcze stałe organy władzy, które w przekonaniu badaczy pozwalają mówić o funkcjach stołecznych pewnego miasta ${ }^{99}$ - albo miasta

93 Szerzej zob. I. Leonavičiūtè, Kariaunos vaidmuo kuriantis Lietuvos valstybei, w: Lietuvos valstybe XII-XVIII a., Vilnius 1997, s. 483.

94 Szerzej zob. М.В. Доўнар-Запольскі, Дзяржаўная гаспадарка Вялікага княства Літоўскага пры Ягелонах, Мінск 2009, s. 131-154; М.К. Любавский, Поседные бояре в Жмудской земле в XVI веке, w: Сергею Фёдоровичу Платонову ученики, друзья и почитатели, Санкт-Петербург 1911, s. 439-449; K. Jablonskis, Lietuviški žodžiai senosios Lietuvos raštinių kalboje, cz. 1: Tekstai, Kaunas 1941, s. 171-180; J. Jurginis, Baudžiavos įsigalejimas Lietuvoje, Vilnius 1962, s. 176-191; Lietuvos istorija..., t. 3, s. 366-372.

95 E. Gudavičius, Mindaugas, Vilnius 1998, s. 109-111.

96 П.В. Лукин, Праздник, пир и вече. К вопросу об архаических чертах общественного строя восточных и западных славян, „Одиссей. Человек в истории. Феодализм перед судом историков" 2006, s. 134-150.

97 М.В. Доўнар-Запольскі, op. cit., s. 728-730 (kom. A. Hruszy).

98 Zob. zestawienie literatury w: Lietuvos istorija..., t. 3, s. 322-327. Na rolę Mendogowej stolicy nie nadaje się "gród” Woruta, gdzie władca ukrył się przed wojskiem Towciwiła w 1251 r.; ПСРЛ ІІ, s. 817-818; E. Gudavičius, Mindaugas, s. 154-163.

99 Według H. Heimpela i K. Neitmanna podstawową cechą pozwalającą upatrywać w tym lub innym mieście średniowiecznym „stolicę" jest stolec (sedes Regni), pod którym pojmowano zarówno 
stołecznego. Nieliczne dokumenty Mendoga z datą i lokalizacją wystawione są „in Lettowia (albo: Lettowie) in curia nostra" ${ }^{100}$. Wydaje się, że „Litwa” oznacza tu, wbrew częstemu stwierdzeniu, nie nazwę dworu, lecz jakieś terytorium, na którym trzeba go szukać. Przy czym niewykluczone, że ścisłe centrum królestwa Mendogowego było nie do końca tożsame z trzonem Wielkiego Księstwa Litewskiego za Giedyminowiczów ${ }^{101}$.

Już za Mendoga zaczęło się formowanie systemu zarządzania przyłączonymi do państwa litewskiego ziemiami ruskimi, gdzie tworzono nowe siedziby książęce albo zachowywano już istniejące ${ }^{102}$. Jednak proces ten przybrał na sile pod rządami dynastii, która objęła władzę w ostatnich dekadach XIII w. i później otrzymała nazwę Giedyminowiczów. Razem ze wzrostem terytorialnym władztwa książąt litewskich jego struktura stawała się bardziej skomplikowana. Na przełomie XIII i XIV w. pod ich władzę trafiła ziemia połocka, ok. 1320 r. - witebska. Na miejscowych stolcach zasiedli członkowie rodu Giedymina ${ }^{103}$. W 1337 r. mamy wiadomość o śmierci „króla Trok”, a więc miasto to także zostało centrum księstwa ${ }^{104}$. Książęta dzielnicowi byli w swoich władztwach nader samodzielni: dysponowali ziemią, samodzielnie wyprawiali się na wojnę, zawierali układy z sąsiadami, bili własną monetę. Wszystkie te uprawnienia nie były przez nikogo podważane, ale praw tych nie mieli już późniejsi namiestnicy i wojewodowie. Te tak szerokie kompetencje zwalniały władców państwa litewskiego z konieczności regularnych objazdów całości ziem, nad którymi sprawowali władzę zwierzchnią. O tym, jaką rzadkością był przyjazd władcy litewskiego na wschodnie pogranicze jego państwa świadczy wiadomość latopisu rogożskiego o przyjeździe Olgierda na

najważniejszy punkt systemu objazdów, jak i np. kościół katedralny; K. Neitmann, Was ist eine Residenz? Methodische Überlegungen zur Erforschung der spätmittelalterlichen Residenzbildung, w: Vorträge und Forschungen zur Residenzfrage, red. P. Johanek, Sigmaringen 1990 (Residenzforschung, t. 1), s. 12-18. Pojęciu temu dobrze odpowiada konstrukcja стольный город/град, spotykana w zabytkach staroruskich; Словарь древнерусского языка XI-XIV вв., t. 2, Москва 1989, s. 358, 379; zob. też A. Gąsiorowski, Polskie itineraria późnośredniowieczne..., s. 235-237.

100 „Datum in Lettowia in curia nostra” - 1253 r. (LUB I 252); „Datum Lettowie in curia nostra” 1253/1260 r. (LUB I 354). Oba dokumenty zachowały się w późniejszych, czternastowiecznych transsumptach. O ile autentyczność drugiego z nich budzi poważne wątpliwości, to pierwszy jest uznawany przez większość badaczy za rzeczywiste dzieło kancelarii Mendoga. W takim razie ten dokument mógł stać się podstawą falsyfikatu z datą $1260 \mathrm{r}$.

101 Por. szczegółowe dane: T. Baranauskas, op. cit., s. 192-203.

102 Т. Баранаускас, Новогрудок в ХІІІ в. История и миф, w: Castrum, urbis et bellum: Зборнік навуковых праи, Баранавічы 2002, s. 29-44.

103 В.А. Варонін, Падзеі 1307 года у Полачку. Спроба крытычнага разбору, ш: Гісторыя і археалогія Полаика і Полачкай зямлі. Матэрыялы V Міжнароднай навуковай канферэнцы (24-25 кастрычніка 2007 г.), Полацк 2009, s. 30-40; В.А. Воронин, Княжение Ольгерда в Витебске, „Ukraina Lituanica. Студії з історії Великого князівства Литовського” 2, 2013, s. 21-38; ПГ II, s. 411-412.

104 SRP II, s. 493-494. 
inspekcję nowo przyłączonej Rżewy ${ }^{105}$. W tej sytuacji okazją do spotkania monarchy zwierzchniego $\mathrm{z}$ książętami dzielnicowymi były wyprawy wojenne ${ }^{106}$ albo ich przyjazdy do Wilna „na narady” („на думы”), o których jest mowa w Latopisie wielkich książat litewskich ${ }^{107}$. Z informacji zawartych w Starszej kronice wielkich mistrzów o wyprawie Kiejstuta na Jagiełłę i Korybuta, którzy „zatrzymali mu jego daninę"108, wynika, że mieli ją dostarczać do Wilna sami książęta dzielnicowi.

Wybór miejsca pobytu władcy litewskiego był bezpośrednio związany ze specyfiką położenia geopolitycznego jego państwa w XIV w. Była to epoka aktywnej walki z zakonem. Rejzy dostojników krzyżackich z Prus i Inflant na Litwę i podległe jej ziemie ruskie (np. Grodno, Połock) w XIV w. powtarzały się praktycznie co roku, czasami nawet kilkakrotnie w tym samym roku ${ }^{109}$. Z kolei książęta litewscy wykorzystywali każdy dogodny moment, aby podjąć wyprawę na Prusy lub Inflanty. Obie strony angażowały znaczne siły w niszczycielską wojnę, która miała na celu osłabienie przeciwnika, pozwalała na uzyskanie czasu i złapanie wytchnienia. To zmuszało książąt litewskich do spędzania większości czasu stosunkowo niedaleko od Prus i Inflant, czyli na Litwie właściwej - w historycznym centrum państwa. Wiosną 1296 r., gdy Witenes wyprawił się do Inflant, komtur Królewca wysłał na „ziemię króla” komtura Balgi. Według Piotra z Dusburga komtur Królewca od dawna i z niecierpliwością oczekiwał na moment, gdy „król Witenes" opuści swą ziemię ${ }^{110}$. Sytuacja powtórzyła się wiek później: na początku 1393 r. dostojnicy krzyżaccy dowiedzieli się, że Witold jest zajęty walką z Korybutem i spalili Grodno.

Między państwem Giedyminowiczów a królestwem Mendoga jest istotna różnica. Podczas gdy nie zachowały się żadne przekazy o mieście stołecznym królestwa litewskiego, co już samo w sobie jest wymowne, to za Giedyminowiczów tę rolę stale pełniło Wilno. Jak pokazują badania archeologiczne, szybki rozwój tego miasta nastąpił w ostatnich dekadach XIII w. i wynikał z inicjatywy władców litewskich, którzy od początku przewidywali dla Wilna rolę centrum administracyjnego ${ }^{111}$. Po raz pierwszy Wilno zostało wspomniane w 1323 r.:

105 ПСРЛ ХV/1, kol. 69.

106 Herold krzyżacki, autor kroniki Wigand z Marburga wymienia wśród uczestników bitwy nad rzeką Strewą wojów z Brześcia, Włodzimierza (Wołyńskiego), Witebska, Połocka, a nawet Smoleńska; SRP II, s. 511.

107 ПСРЛ ХХХV, s. 61.

108 SRP II, s. 602. Tu warto zauważyć jedną nieścisłość: według innych źródeł Kiejstut liczył na wierność Jagiełły i ten miał towarzyszyć mu w wyprawie przeciwko Korybutowi, ale poczekał aż Kiejstut opuści Wilno i sam zajął miasto.

109 W. Paravicini, Die Preussenreisen des europäischen Adels, cz. 2, Sigmaringen 1995 (Beihefte der Francia. t. 17/2); Lietuvių karas su kryžiuočiais, red. J. Jurginis, Vilnius 1964.

110 SRP I, s. 163 (cap. 267).

111 Г. Вайткявичюс, Вильнюс: от поселения до королевского города, w: Археология и история Литвы и Северо-Запада России в Средневековье. Доклады российско-литовского семинара. 
stąd zostały napisane słynne listy Giedymina do mieszkańców północnych Niemiec, tu Giedymin przyjmował posłów papieża i miasta Rygi oraz zawierał układ $\mathrm{z}$ Inflantczykami ${ }^{112}$. Już w momencie śmierci Giedymina (1341 r.) uznawano, że posiadanie Wilna jest koniecznym warunkiem objęcia stolca wielkoksiążęcego ${ }^{113}$. Układ inflanckiej gałęzi zakonu krzyżackiego z książętami litewskimi z 1367 r. („pokój łotrzyków”) przewidywał jego zerwanie z inicjatywy strony inflanckiej w Wilnie, litewskiej zaś w Rydze ${ }^{114}$. Dostojnik krzyżacki, autor listu o wyprawie na Litwę, zapewne z 1377 r., postrzegał Wilno jako główne miasto państwa, natomiast przebywającego tam Olgierda nazwał „wielkim królem” i „panem całego królestwa"115. W 1387 r. Jagiełło ufundował w Wilnie pierwszą katedrę litewską biskupa katolickiego, natomiast „łacińska” część mieszczan otrzymała odeń przywilej samorządu. W listopadzie 1390 r., w liście do króla rzymskiego o niedawnej rejzie na Litwę wielki komtur Konrad von Wallenrode nazywał Wilno „głównym zamkiem położonym w ziemi litewskiej” („das houpthous im lande czu Littawen gelegen") ${ }^{116}$. Są zatem przesłanki do określania Wilna jako miasta stołecznego Wielkiego Księstwa Litewskiego już w XIV w., nawet przy pewnej umowności tego terminu (przypomnę, że za główne kryterium statusu stołeczności danego ośrodka zwykle uważa się usytuowanie w nim centralnych instytucji zarządu, których w czternastowiecznym państwie litewskim jeszcze nie było ${ }^{117}$ ).

Taką sytuację zastał Witold w latach młodzieńczych. Zapewne znaczną rolę w kształtowaniu się praktyki jego rządzenia odegrała także struktura władztwa Kiejstuta - Witoldowej „ojcowizny”. Jak wynika z Latopisu wielkich książąt litewskich, który powstał w otoczeniu Witolda, jej głównymi centrami były Troki i Grodno, w mniejszym stopniu zaś Drohiczyn i Brześć, wspomniane w związku z kontaktami Kiejstuta i Witolda z ich szwagrami - książętami mazowieckimi ${ }^{118}$. Niedługo po śmierci Lubarta (1383 r.) dołączył do nich Łuck, który Jagiełło

Вильнюс, 28-30 марта 2011 г., Вильнюс 2013, s. 81-107; zob. też O. Valioniené, Viduramžiu Vilnius. Erdvés evoliucija (XIII a. vidurys - XVI a. pirmas ketvirtis), Vilnius 2019.

112 Zob. najnowszą edycję dokumentów i listów Giedymina: Chartularium Lithuaniae res gestas magni ducis Gedeminne illustrans. Gedimino laiškai, wyd. S.C. Rowell, Vilnius 2003.

${ }^{113}$ O tym dowodnie świadczy opowiadanie Skargi Witolda o obaleniu Jawnuty przez Olgierda i Kiejstuta (SRP II, s. 712), później przejęte w Latopisie wielkich książąt litewskich.

114 Chartularium Lithuaniae..., nr 81, s. 302-303.

115 SRP II, s. 586-587, Anm. 1155.

116 CDP IV 80; Lites II, s. 418 (tłum. S.P.).

117 Wykształcenie się instytucjonalnego dworu wielkoksiążęcego i kancelarii nastąpiło pod koniec XIV w.; M. Kosman, Kancelaria...; R. Petrauskas, Didžiojo kunigaikščio institucinio dvaro susiformavimas... O funkcjach stołecznych Wilna zob. M. Kosman, Problem stołecznych funkcji Wilna do połowy XVI wieku, ZH, 64, 1999, nr 3-4, s. 37-65; R. Ragauskienė, Lietuvos valdovu vilnietiški itinerariumai, w: Vilniaus žemutiné pilis XIV a. - XIX a. pradžioje. 2002-2004 m. istoriniu šaltiniu paieškos, Vilnius 2006, s. 304-330. Pojęcia stolicy w Wielkim Księstwie Litewskim zaczęto używać znacznie później, dopiero w przededniu zawarcia unii lubelskiej.

118 ПСРЛ ХХХУ, s. 62-63. 
przekazał Witoldowi ${ }^{119}$. Po powrocie Witolda z Prus (1392 r.) i nawet po następnym rozszerzeniu jego władzy na całe terytorium Wielkiego Księstwa Litewskiego nadal orientował się on na ten znany mu obszar, jak pokazuje przytoczony już przykład wyboru miejsca przyjęcia poselstwa krzyżackiego w 1396 r. Później czas wolny od wypraw wojennych Witold spędzał głównie na Litwie właściwej i w sąsiedniej ziemi grodzieńskiej. Rezygnacja z ukształtowanej tradycji nie miała sensu: na otoczenie wielkiego księcia składali się możnowładcy, których gniazda rodowe znajdowały się na Litwie właściwej, przy tym kierunek prusko-inflancki zachowywał swoje znaczenie w polityce litewskiej, natomiast utwierdzać swoją władzę Witold potrafił bez kosztownych objazdów. Jednocześnie za jego panowania główna rezydencja władcy - jak się wydaje - została przeniesiona $\mathrm{z}$ Wilna do Trok, gdzie zbudowano - zapewne przed 1408 r. - imponujący zamek na wyspie ${ }^{120}$.

Mediewiści wydzielają dwie podstawowe funkcje podróży średniowiecznych monarchów po ich władztwach: były odbywane „zarówno po to, aby zużywać na miejscu plony swoich włości [...], jak i po to, aby w coraz to innym miejscu poświadczyć konkretnie, przez swoją obecność, królewską władzę"121. Jakie miejsce te i inne funkcje zajmowały w podróżach Witolda i jak je organizowano? Aby odpowiedzieć na to pytanie, warto przede wszystkim zbadać wielkie objazdy ${ }^{122}$ Wielkiego Księstwa Litewskiego w latach 1411 i 1427, przywołując też niektóre inne przykłady.

Wiosną 1411 r. w Wilnie Witold i Jagiełło przyjęli legata papieża Jana XXIII, posłów króla węgierskiego Zygmunta Luksemburskiego, mistrza inflanckiego i Nowogrodu Wielkiego. Stąd razem z posłami inflanckimi udali się do Połocka, gdzie - ku niezadowoleniu mistrza inflanckiego - spotkali się z posłami

119 Ibidem, s. 63. W literaturze istnieją różne opinie nt. przynależności ziemi łuckiej w latach 1388-1389: jedni badacze (jak A. Prochaska) pisali o władzy Witolda nad nią, podczas gdy inni (J. Fijałek, O. Halecki) odrzucali ich argumenty. Uważam, że słowa Witolda w jego memoriale z przełomu lat 1389 i 1390 o nadaniu mu ziemi łuckiej przez Jagiełłę bez zatwierdzenia specjalnym przywilejem (SRP II, s. 712-714) są zgodne z prawdą. Przemawia za tym zarówno tytulatura Witolda (zob. CEV 63, 64), jak i jego przywilej dla Żydów brzeskich; zob. zwł. С. Лазутка, Э. Гудавичюс, Привилегия евреям Витаутаса Великого 1388 года, Москва-Иерусалим 1993 (tamże o kwestii autentyczności). Zapewne Jagiełło, nadawszy ziemię łucką Witoldowi, zachował nad nią władzę zwierzchnią.

120 T. Baranauskas, op. cit., s. 203 (próba wyliczenia średniej długości przebywania Witolda w różnych centrach jego władztwa). Nadal aktualna pozostaje praca o trockim zamku na wyspie: Z. Ivinskis, op. cit. (tu też o dacie jego wzniesienia).

121 G. Duby, R. Mandrou, Historia kultury francuskiej, wiek X-XX, tłum. H. Szumańska-Grossowa, Warszawa 1967, s. 19; cyt. za: A. Gąsiorowski, Podróże panującego..., s. 41-42.

122 Terminu „wielki objazd” używam za A. Rutkowskim i A. Gąsiorowskim na oznaczenie objazdów, podczas których władca opuszczał centralną część państwa; A. Rutkowski, Objazdy i system rządzenia państwem przez Kazimierza Wielkiego, „Kwartalnik Historyczny” 85, 1978, nr 3, s. 621-622; A. Gąsiorowski, Polskie itineraria późnośredniowieczne..., s. 226. 
pskowskimi ${ }^{123}$, następnie zaś do Smoleńska, gdzie do Witolda przybył wielki książę riazański Fiodor Olegowicz z Zofią Witoldówną, żoną wielkiego księcia moskiewskiego Wasyla I, i „oddał się mu w służbę”. Potem z Krzyczowa, posiadłości Lingwena Olgierdowicza ${ }^{124}$, który wtedy miał kormlenie w Nowogrodzie, ale przybył na Litwę, obaj władcy spłynęli Dnieprem do Kijowa, gdzie spotkali się z wielkim księciem twerskim Wasylem I, chanem tatarskim Dżelal-ed-Dinem i metropolitą Focjuszem, który konsekrował kilku biskupów. Tamże zawarto sojusz, przewidujący wzajemną pomoc Witolda, Jagiełły, Wasyla I, Nowogrodu Wielkiego i Dżelal-ed-Dina ${ }^{125}$. Po rozstaniu z Witoldem Jagiełło znowu spotkał się z nim w Glinianach. Nie można zgodzić się z opinią Giedrè Mickūnaitė, że "parada" ta nie wywarła żadnego wrażenia na poddanych Witoldowych ${ }^{126}$. Po pierwsze, jeszcze rok później sługa krzyżacki donosił wielkiemu mistrzowi z Kijowa o sojuszu Witolda i Jagiełły z „poganami”"127, a po drugie, jak pokazał Jurij Mikulski, wrażenia Herasyma, przyszłego metropolity Wszechrusi, 17 lat później odbiły się w jego Pochwale Witolda ${ }^{128}$.

Jak widać, ze względu na specyfikę zachowanych źródeł, skupiających uwagę na aspektach międzynarodowych objazdów wielkiego księcia, badacze mają niewiele informacji o jego kontaktach z poddanymi. Te dwa wątki dobrze pokazują dane o podróży Witolda do południowej części jego władztwa w 1424 r., aczkolwiek wyjazd ten miał znacznie mniejszą skalę niż objazdy w latach 1411 i 1427. Kierując się troską o zdolności obronne ziem południowych Wielkiego Księstwa Litewskiego ${ }^{129}$,

123 „Unde von dannen tzogen sie ken Ploskouwe, dar ouch unser boten qwemen unde der Plesko[u]wer sendeboten", GStAPK, OBA 1538 = LUB IV 1888. Ponieważ w edycji tekst przekazany niedokładnie - zamiast Ploskouwe (Połock) wydrukowano Pleskouwe (Psków), zapis poprawiono na podstawie oryginału.

124 А.А. Мяцельскі, Мсціслаўскае княства і ваяводства ў XII-XVIII cтст., Мінск 2010, s. 124-153. Ciekawe, że w 1422 r. w drodze do Czech w Krzyczowie przebywał Zygmunt Korybutowicz; GStAPK, OBA 3705 = J. Boubín, Tři korybutovské písemnosti (Materiálová studie s edicí), „Folia Historica Bohemica” 4, 1982, s. 227-228).

125 GStAPK, ОВA 1768 = С.В. Полехов, Лугвень..., s. 73-74.

126 G. Mickūnaite, A Medieval Parade?, w: ...The Man of Many Devices, who Wandered Full Many Ways... Festschrift in Honor of János M. Bak, red. B. Nagy, Budapest 1999, s. 277-280.

127 „Derselbige unser dyner gebit uns czu vorsteen, das herczog Witout als stark sich habe besamelt mit der heydenschaft, das der ouch ane czall ist; dese czeitunge hat er uns von Kiwen empoten. Wir dirkennen den knecht also worhaftig, das her uns nicht vorlüget. Hirin moget ir dirkennen, das der koning von Polan und herczog Witawten vor eyme jare dohindene in den heydenisschen landen sulche vorbuntnisse mit den heyden off des Ordens gruntliche vorterbnisse und desem orte der Cristenheyt, do Got vor sy, habe gemachet", GStAPK, OBA $1707=$ CEV $495^{*}$.

128 Mikulski 2011, s. 81-89.

129 O tym świadczą skargi Witolda na najazdy tatarskie w liście do papieża Marcina V wyekspediowanym latem 1424 r. oraz podjęcie tematyki tatarskiej w liście do wielkiego mistrza z 22 czerwca, w którym wielki książę pisał o zamiarze dokonania przeglądu swoich zamków w „dalekich ziemiach ruskich"; CEV 1159, 1160; LC I 18. 
Witold nie tylko dokonał inspekcji zamków ${ }^{130}$, ale też rozdał dobra materialne swoim poddanym (albo zatwierdził już dokonaną przez nich wymianę posiadłości) ${ }^{131}$, co miało stworzyć warunki dla kosztownej i niebezpiecznej służby na pograniczu oraz umocować władzę Witolda na Podolu Zachodnim, które otrzymał $\mathrm{w}$ dożywocie. Ponadto wielki książę spotkał się z królem polskim oraz - niechętnie - z posłami pskowskimi.

Najbardziej znanego objazdu swego władztwa - a dokładniej, jak sam pisał, „dalekich ziem ruskich"132 - Witold dokonał latem 1427 r. Na początku roku przebywał na Litwie właściwej: 17 marca pisał do wielkiego mistrza o przebytej chorobie, po której już mógł chodzić, stać i siedzieć, ale jeszcze odczuwał gorączkę. Nie zapominał jednak o sprawach państwowych, m.in. o bardzo dalekich kierunkach polityki zagranicznej - $\mathrm{w}$ tym samym liście poruszał tematy tatarskie i wołoskie, ponadto zajmował się budowaniem zamków nad Morzem Czarnym i przesyłał dostojnikom krzyżackim ryby schwytane przy ujściu Dniestru do tego morza, a już niedługo później przyjmował poselstwo tureckie ${ }^{133}$.

W czerwcu wyruszył w drogę. Pod koniec miesiąca spotkał się w Mińsku ze swoją córką Zofią, która specjalnie przyjechała z Moskwy, gdzie pozostał jej 12-letni syn Wasyl. Tamże hospodar litewski przyjął i hojnie obdarzył dwóch rycerzy, którzy potem udali się do Torunia ${ }^{134}$. 14 lipca był już w Krzyczowie u Lingwena. Trasę dalszej podróży Witolda możemy zrekonstruować na podstawie dwóch listów do wielkiego mistrza, spisanych tego samego dnia, 14 sierpnia,

${ }^{130}$ Według listu Witolda do wielkiego mistrza jednym z celów jego wyjazdu na Podole był przegląd zamków; CEV 1159. Podobnie Jagiełło w 1421 r. dokonywał inspekcji zamków na Podolu Zachodnim, nadanych Witoldowi w dożywocie: „Ouch so spricht her [szpieg, który był w Polsce - S.P.], das der koning von Polan noch so lange in der Podolyee ist gewest unde hat syne hůwßer obirall do bestalt", GStAPK, OBA 3569; o dacie zob. Jóźwiak 2004, s. 242-243).

131 Kurtyka. Rep. $163^{\star}, 164^{\star}, 165^{\star}, 167^{\star}, 168^{\star}$.

132 CEV 1291, 1298.

${ }^{133}$ CEV 1270, 1286; „Anno 27 am sontage Esto michi schicktt herczogk Wytoldt dem hoem. 10 grosse fische, schanrihen genandt, die er gefangen hatt in dem mere an der munde, do das grosse vließ, der Nester genendt, fellett inst Tartarischen gestilde, und daß grosse fließ Direpe, unsers landes gen mittage und wert biß gen Constantinopol, und er habe do lassen heuser und schlosser bauen. Bittet derhalben den hoem: wen dieselbige fische noch geandtwortelt werden, welett euere 10 dorfon nemen, und die andern, die noch ungeteiltt, diesen nochgeschriben heren werschicken, alß dem großcom., obersten marschalck, com. zu Elbinge, herczog Michelß, unsers brudern son, com. zu Cristb., tresler, com. zur Balge, com. zu Brandenb., com. zu Rangnith und dem alden marschalck", LMAVB RS, F 15-73, s. 334. O kontaktach Witolda z Imperium Osmańskim zob. L. Korczak, Znajomość spraw tureckich w Wielkim Księstwie Litewskim w XV wieku, „Zeszyty Naukowe Uniwersytetu Jagiellońskiego. Prace Historyczne”, z. 119: „Studia Polono-Danubiana et Balcanica" 8, 1995, s. 143-147.

${ }^{134}$ Zachował się list polecający Jagiełły z 8 VII 1425 r. dla tych rycerzy, udających się na Litwę, a stąd do Grobu Pańskiego: GStAPK, OBA 4453 = KDL, s. 303-304 = A. Szweda, Listy Władysława Jagiełly do wielkich mistrzów krzyżackich w latach 1386-1434, w: Tekst źródła, krytyka, interpretacja, red. B. Trelińska, Warszawa 2005, nr 64. 
w Smoleńsku, przez samego wielkiego księcia i jego błazna Hennego (w literaturze czasami niesłusznie zwanego szpiegiem) ${ }^{135}$. Z listu Hennego dowiadujemy się, że Witold udał się do ziem książąt Zygmunta Kiejstutowicza i Świdrygiełły. Centrami ich władztw były Starodub i Czernihów. Zapewne pojechał tam przez Posoże. Z władztwa Świdrygiełły udał się do Mezecka, a stamtąd do pewnego miasta pod zarządem wojewody (może Mceńska), gdzie przybyli do niego książęta riazańscy, prońscy i nowosilsko-odojewscy, by złożyć hołd lenny. Stąd Witold wyruszył do Smoleńska, spłynął Dnieprem do Kijowa, a potem przez Ostróg, Łuck i Włodzimierz udał się do Horodła. Tam spotkał się z Jagiełłą, a następnie przez Brześć, Mielnik, Drohiczyn i Grodno wrócił na Litwę właściwą. Dosyć zawikłana trasa jego podróży przy bliższym przyjrzeniu okazuje się doskonale przemyślana. Wielki książę spotkał się z wieloma poddanymi, m.in. z kilkoma książętami dzielnicowymi, oraz $\mathrm{z}$ władcami sąsiednich ziem ruskich i królem polskim, przyjął poselstwa chana tatarskiego, sułtana tureckiego, wielkiego księcia moskiewskiego i władz Nowogrodu Wielkiego, otrzymał też listy od wielkiego mistrza. Te ostatnie dostarczono mu dzień przed przyjazdem do Smoleńska, a więc urzędnicy Witolda potrafili bez zbytniego trudu znaleźć go $\mathrm{w}$ drodze, poza którymś $\mathrm{z}$ wielkich ośrodków (aczkolwiek w stosunkowo niewielkiej odległości od jednego z nich) ${ }^{136}$. Przy czym Witold odrzucił zaproszenie córki Zofii i nie pojechał do Moskwy, bo to naruszyłoby plan jego podróży po ziemiach ruskich. Spotykając Witolda, poddani obdarowywali go - i zapewne jego dworzan, jak można sądzić z zachwycającej relacji Hennego - końmi, sobolami, futrami, jedwabnymi tkaninami, złotem, tatarskimi pieniędzmi i innymi przedmiotami. Z kolei Witold nie tylko rozdawał stawającym przed nim ruchomości, ale też nadawał ziemię, o czym świadczy kilka dokumentów wystawionych podczas tej podróży. Zwraca uwagę fakt, że Witold planował opuścić Smoleńsk w następnym dniu po Wniebowzięciu NMP, które to wezwanie nosiła katedra eparchii smoleńskiej.

Jak pokazują przytoczone dane, zjawienie się monarchy przed jego poddanymi w odległych częściach Wielkiego Księstwa Litewskiego wymagało znacznych wydatków. Objazdy kraju planowano zawczasu - jak trafnie zauważył Jan

135 Oba listy są opublikowane: CEV 1298, 1329. Drugi, napisany przez Hennego i datowany na wigilię Wniebowzięcia NMP, jego wydawca A. Prochaska błędnie odniósł do 1428 r., łącząc z wyprawą Witolda na Nowogród Wielki. Później sam wskazał prawidłową datę roczną (1427) w biografii Witolda, następnie pisali o tym także inni badacze; A. Prochaska, Dzieje Witolda, w. księcia Litwy, Wilno 1914, s. 245, przyp. 1; S.M. Kuczyński, Ziemie czernihowsko-siewierskie pod rzadami Litwy, Warszawa 1936, s. 375; Р.А. Беспалов, Источники о поездке Витовта в область Новосильского и Рязанского княжеств в 1427 году, w: Верхнее Подонье: археология, история, t. 3, Тула 2008, s. 256-259. Niemniej badacze czasami wciąż przywołują ten list pod 1428 r.; Tęgowski 2006, s. 74-75; Jóźwiak 2004, s. 119-120 (tu o rzekomym szpiegostwie Hennego).

136 Tak samo w lipcu 1417 r. Witold otrzymał list wielkiego mistrza w drodze z Kijowa do Nowogródka (CEV 643), w październiku 1418 r. - z Trok do Siemieliszek (CEV 796). 
Tęgowski, „co najmniej z dwumiesięcznym wyprzedzeniem”"137. Itinerarium Witolda przekonuje, że zwykle takie planowanie okazywało się w miarę dokładne, chociaż niespodziewane przeszkody komunikacyjne nie wykluczały odstąpienia od wcześniej przyjętego grafiku: 17 stycznia $1429 \mathrm{r}$. Witold pisał do wielkiego mistrza, że nie zdąży - jak zamierzał - przybyć do Trok 8 lutego, z powodu opóźnienia króla rzymskiego, który przyjedzie do Łucka dopiero dwa tygodnie po wyznaczonym terminie ${ }^{138}$. Niemniej takie odchylenia od wcześniej przyjętego planu zdarzały się rzadko. Jak pokazują dane z ostatnich lat panowania Witolda i okresu rządów wileńskich Świdrygiełły, wielki książę dosyć intensywnie podróżował między dworami Litwy właściwej ${ }^{139}$. To zapewne wiązało się z tym, że środki, które można było skupić na takim dworze dla przyjęcia hospodara i jego dworu, były ograniczone ${ }^{140}$. Większe możliwości istniały w takich wielkich ośrodkach jak Troki, gdzie Witold zamierzał spędzić 12 tygodni, gdy dowiedział się o ucieczce Świdrygiełły z niewoli krzemienieckiej i obawiał się zdrady ${ }^{141}$. Urzędnicy byli informowani o dokładnym terminie przyjazdu hospodara i trasie jego przejazdu, zapewne listownie lub za pomocą gońców („prystawów”?) ${ }^{142}$.

Nierównomierność zasięgu terytorialnego podróży hospodarskich po terytorium Wielkiego Księstwa Litewskiego dobrze widać $\mathrm{z}$ danych o łowach wielkoksiążęcych: świadectwa te w są większości związane z pobytami władcy w centrum państwa. Obszary łowieckie na Litwie właściwej i na południe od niej (między Litwą i Wołyniem) były lepiej zagospodarowane: przekonują o tym zarówno częste wzmianki o dworach myśliwskich, w tym „nowych", będących miejscem spisywania listów i dokumentów ${ }^{143}$, jak również obyczaj Witolda i Jagiełły spędzania -

137 Tęgowski 2006, s. 68; zob. np. CEV 1159, 1206, 1214, 1298; Liedtke 1932, s. 148-149.

138 CEV 1338.

139 Ghillebert de Lannoy zauważa: „Tam, we wskazanym zamku, znalazłem księcia Witolda, pana Litwy, jego żonę i jego córkę, żonę wielkiego króla moskiewskiego [grant roy de Musco] oraz córkę córki. I ów książę przybył tam, by polować w tamtejszych lasach, jak on zwykle czyni raz na rok zimą, spędzając tam trzy tygodnie lub jeden miesiąc, polując i nie wjeżdżając ani do swoich dworów [dosł. „domów”, „siedzib”], ani do miast”; Klimas 1933, s. 154; Kraštas ir žmonés. Lietuvos geografiniai ir etnografiniai aprašymai (XIV-XIX a.), wyd. 2 uzup., wyd. J. Jurginis, A. Šidlauskas, Vilnius 1988, s. 51-52 (za tłumaczenie tego fragmentu pragnę podziękować prof. O.F. Kudriawcewowi). Uwagę rycerza burgundzkiego spowodowała niezwykłość takiej praktyki rezydowania: książęta burgundzcy dosyć często zmieniali miejsce pobytu, preferując wielkie miasta; por. solidny tom itinerariów: H. Vander Linden, Itinéraires de Philippe le Bon, duc de Bourgogne (1419-1467) et de Charles, comte de Charolais (1433-1467), Bruxelles 1940.

140 Por. C. Ehlers, Um 1012. Wie sich ambulante zu residenter Herrschaft entwickelt hat, w: Die Macht des Königs: Herrschaft in Europa vom Frühmittelalter bis in die Neuzeit, red. B. Jussen, München 2005, s. 115-117.

141 CEV 766.

142 Takie określenie występuje w liście Świdrygiełły do wielkiego mistrza z 16 VI 1432 r.; GStAPK, OBA 6133; R. Petrauskas, Vytauto dvaras..., s. 42.

143 Zob. np. CEV 519, 658, 755, 861; ПГ І 36. 
właśnie dla polowań - zimy na Litwie ${ }^{144}$ czy uwaga Witolda w liście do wielkiego mistrza z 19 grudnia 1428 r., że on i Jagiełło pojadą z Grodna do Łucka różnymi drogami z powodu królewskich polowań ${ }^{145}$.

Myślistwo w średniowieczu było jedną z ważniejszych form spędzania wolnego czasu przez przedstawicieli elit, a także okazją do politycznych kontaktów, oprócz tego stanowiło ekonomiczną konieczność. Na polowaniu w Lasach Dawidowych w 1380 r. zawarto układ z wielkim mistrzem, a w 1387 r. Jagiełło przekazał Skirgielle władanie nad księstwami trockim, połockim i mińskim, znajdując się „oy ловехъ Скоистерскихъ” w pobliżu Wilna ${ }^{146}$. Znaczenie tych łowów przetrwało także w późniejszym okresie ${ }^{147}$. Prawo wielkiego księcia litewskiego i króla polskiego do polowań we władztwach zakonnych było zastrzeżone w specjalnych dokumentach ${ }^{148}$. Oczywiście warunki do polowań istniały nie tylko na Litwie, ale i w innych ziemiach Wielkiego Księstwa ${ }^{149}$, jednakże ilość spotkań z poddanymi, władcami i posłami zagranicznych państw, a także wyczerpujące przejazdy $\mathrm{z}$ jednego miejsca noclegu do drugiego nie stwarzały dobrych okoliczności do uczestniczenia w łowach.

Analizowane podróże miały największy zasięg geograficzny. Towarzyszyć w nich Witoldowi musiało wiele osób. Niestety, dokładnej liczebności jego dworu nie sposób ustalić z przyczyn zarówno natury źródłowej, jak i metodycznej: z jednej strony badacze nie dysponują podstawowym źródłem dla tego rodzaju wyliczeń - rachunkami dworu hospodarskiego, $\mathrm{z}$ drugiej zaś nawet $\mathrm{w}$ razie ich zachowania nie do końca jasne jest, kogo i w jaki sposób zaliczać do grona dworzan, służby dworskiej, urzędników i ich klienteli, jaką zakładać normę konsumpcji produktów itd. ${ }^{150}$ Według opinii Rimvydasa Petrauskasa, w znacznej mierze opie-

${ }^{144}$ R. Jaworski, Łowy Władysława Jagiełly, w: R. Jaworski, P. Chojnacki, Z biografistyki Polski późnego średniowiecza, red. M. Koczerska, Warszawa 2001 (Fasciculi Historici Novi, t. 4), s. 7-86.

145 „Auch so sein wir iczunt bei enandir mit dem herren konige van Polan czu Garten, und von danne czihen wir nu kein Lauczke einen wek, und der herre konig einen andirn wek umme seiner jagit willen", CEV 1336.

146 ПГ I 16.

147 W formie zniekształconej (Kostiri, Koszthery) wieś tę wspomina Długosz w opisie wizyty Jagiełły na Litwie w 1415 r. W indeksie geograficznym jego itinerarium te „Kostery” są hipotetycznie utożsamione z Koszedarami albo Kostykami; Dług. XI, s. 56; Gąsiorowski 2015, s. 82, 131.

148 K. Neitmann, Jagdbriefe im diplomatischen Verkehr des Deutschen Ordens mit Polen-Litauen um 1400, „Preussenland” 24, 1986, nr 2, s. 25-33; J. Śliwiński, Krzyżackie przywileje wolnego polowania dla Władysława Jagiełly $i$ Witolda w latach 1398-1420, w: Odkrywcy, princepsi, rozbójnicy, red. B. Śliwiński, Gdańsk 2007 (Studia z Dziejów Średniowiecza, t. 13), s. 333-348.

149 Por. w ziemi połockiej: ПГ I 365, 476 ( $\$ 21$ przywileju dzielnicowego 1511 r. - o możliwym wyjeździe wojewody „na łowy”). Z polowaniem książąt Koriatowiczów latopisarska Opowieść o Podolu wiąże założenie Kamieńca.

150 Te problemy dobrze ukazuje art. B. Czwojdrak, Liczebność dworów późnośredniowiecznych i wczesnonowożytnych władców polskich, „Roczniki Dziejów Społecznych i Gospodarczych” 76, 2016, s. 209-224. 
rającej się na analogii z sytuacją w sąsiedniej Koronie, ocenianej przez różnych badaczy i z różnymi wynikami - na początku XV w. ogólna liczba dworzan Witolda wynosiła kilkaset osób ${ }^{151}$. Taka sama była liczebność uczestników zjazdów polsko-litewsko-krzyżackich na przełomie XIV i XV w. tylko po stronie krzyżackiej $^{152}$. Oczywiste jest, że nie wszyscy dworzanie towarzyszyli Witoldowi w jego podróżach, a wielkość jego orszaku była związana z takimi czynnikami jak cel, kierunek, czas trwania podróży i szybkość przemieszczania się, pora roku itd. ${ }^{153}$ Oprócz dostojników i dworzan wielkiemu księciu towarzyszyło zapewne duchowieństwo, co było istotne zwłaszcza podczas jego podróży na Ruś, ze względu na rzadką sieć parafii katolickich poza Litwą właściwą ${ }^{154}$. Niekiedy też towarzyszyli mu przebywający w Wielkim Księstwie władcy państw sąsiednich i ich posłowie. Na pewno też personel kancelaryjny: $w$ drodze monarcha nie przestawał prowadzić korespondencji z władcami państw sąsiednich, z własnymi urzędnikami, a także wystawiać przywileje dla poddanych ${ }^{155}$. Pisarze towarzyszyli Witoldowi

151 R. Petrauskas, Didžiojo kunigaikščio institucinio dvaro susiformavimas..., s. 21; por. o liczebności orszaku niemieckich i polskich „monarchów objazdowych”: A. Gąsiorowski, I. Skierska, op. cit., s. 70,74 .

152 A. Szweda, Habitacula omnibus proventibus et commeatibus referta. Problemy zaopatrzenia w żywność podczas zjazdów polsko-litewsko-krzyżackich w I połowie XV wieku, w: Dobrou chut', velkoměsto, Praha 2007, s. 29-31.

153 Niektórzy historycy twierdzą, że liczebność świty Witolda podczas objazdu 1411 r. wynosiła 5 tys. ludzi, przy czym powołują się na znany list mistrza inflanckiego do wielkiego mistrza krzyżackiego z 11 VII 1411 r.; zob. np. Mikulski 2011, s. 85; D. Wróbel, Elity polityczne Królestwa Polskiego wobec problemu krzyżackiego w czasach Władysława Jagiełty, Lublin 2017, s. 292, przyp. 460. Wynika to jednak z błędnej interpretacji tekstu źródła, w którym mowa jest o tym, że Witold zamierzał najechać Księstwo Riazańskie na czele pięciotysięcznego wojska: „Und van dar tzogen die heren ken Smalenczek, dar eyn herzoge van Rosam genant qwam mit herczogen Witoutes dochter, der Witoutes vyand lange ghewest was, und dirgab sich do in syne gnade, wante her gros besorget was, das en die heren beiden mit der grossen schar volkes, nemelich wal vunff [nadpisane nad wykreślonym: vůmfftich - S.P.] tusent mannen, obirczihende worde", GStAPK, OBA 1538 = LUB IV 1888, tekst skolacjonowany $\mathrm{z}$ oryginałem.

154 Już 4 VIII 1394 r. Witold dostał od papieża Bonifacego IX prawo korzystania z ołtarza przenośnego; Bullarium Poloniae, t. 3: 1378-1417), wyd. I Sułkowska-Kuraś, S. Kuraś, Romae-Lublini 1998, nr 377, s. 65.

155 CEV 649, 1298. Na przykład podczas wielkiego objazdu Wielkiego Księstwa Litewskiego latem 1427 r. Witoldowi towarzyszył jego pisarz, który spisał kilkadziesiąt listów i dokumentów tego księcia w latach 1421-1430 („ręka nr 9” oddziału łacińsko-niemieckiego kancelarii Witolda według klasyfikacji R. Čapaitė; eadem, Gotikinis kursyvas..., s. 364-380, 511), a także jeszcze jeden, już nie tak aktywny („ręka nr 10” według tej samej klasyfikacji, znane są spisane przez niego listy i dokumenty $z$ lat 1426-1430; ibidem, s. 380-384). Ten sam pisarz spisał dwa dokumenty ruskie Witolda - przywileje nadawcze dla Jeśka Nieszewicza (Ostróg, 1427 r.) i Biedrzycha (Turzysk Włodzimierski, 1429 r.); W. Kuraszkiewicz, Gramoty XIV-XV wieku. Studjum filologiczne, „Byzantinoslavica” 4, 1932, s. 352-353. Ghillebert de Lannoy pisze, że latem $1421 \mathrm{r}$. w Krzemieńcu Witold wydał mu glejty pisane „po tatarsku, po rusku i po łacinie”; Кудрявцев 2003, nr 12, s. 79. 
także w czasie wypraw wojennych: będąc na początku 1393 r. w Nowogródku, skąd nieco wcześniej wygnał Korybuta, Witold nadał dominikanom łuckim młyn koło Łucka, a w 1428 r. we Rżewie (późniejszej Rżewie Pustej), wracając z wyprawy na Nowogród, rozdał ziemie jej uczestnikom z Wołynia i Podola. Jeden list z początku $\mathrm{XV}$ w. zawiera bezpośrednią wzmiankę o przybyciu Witolda razem z jego dworem i licznymi „gośćmi”" ${ }^{156}$. Nawet jeżeli przypuszczać, że liczebność orszaku wielkoksiążęcego w codziennych podróżach mogła wynosić kilkadziesiąt osób, wymagało to specjalnego przygotowania artykułów spożywczych, miejsc postojów i dróg pomiędzy nimi. To zmuszało do planowania takich podróży zawczasu.

Średnia szybkość przemieszczenia Witolda podczas jego podróży wynosiła 25-35 km dziennie ${ }^{157}$. Z Wilna do Trok dojeżdżał w ciągu jednego dnia. Krewo, według słów Hennego, było miejscem czwartego noclegu od Trok ${ }^{158}$. Odległość tych miejscowości na dzisiejszej autostradzie E28 wynosi ok. $105 \mathrm{~km}$. A więc dziennie Witold pokonywał na tym odcinku przeciętnie $26 \mathrm{~km}$. Przywilej wielkiego księcia litewskiego Aleksandra Jagiellończyka z 2 lipca 1495 r. wspomina o liście Witolda dla Bliźńca (albo Bliźnica), dziada „ludzi przewłockich” powiatu słonimskiego, którym wyzwolił ich od wielu powinności za stacje ${ }^{159}$. Majątek Przewłoka znajdował się w odległości ok. $30 \mathrm{~km}$ na południowy zachód od Słonimia ${ }^{160}$, co również odpowiada wskazanej wyżej dziennej normie przejazdu. Mniej więcej z taką prędkością przemieszczali się monarchowie także w innych krajach: np. w Niemczech było to ok. 12-15 km w krótkoterminowych podróżach, $20-25 \mathrm{~km}$ - w odległych (wówczas mogło to być nawet $35 \mathrm{~km}$ ) ${ }^{161}$. Zresztą takie tempo przemieszczania się nie było granicą możliwości dla ludzi w owych czasach,

156 Niedatowany list nieznanego bliżej namiestnika do „rządcy” (procurator) z rozkazem przygotowania prowiantu dla Witolda i jego orszaku oraz furażu dla ich koni zachował się w formularzu biskupa trydenckiego Aleksandra Mazowieckiego: EFE II 117. Zapewne dotyczy obszaru Królestwa Polskiego, gdzie powszechną praktyką było prowadzenie korespondencji po łacinie, czemu nie przeczy tradycyjne tytułowanie Witolda jako nostri principis. $\mathrm{O}$ tym formularzu zob. A. Larczyńska, Prawdziwe czy zmyślone? Źródła epistolarne i dokumentowe w formularzu księcia mazowieckiego Aleksandra. Próba rekonesansu badawczego, „Studia z Dziejów Średniowiecza” 18, 2014, s. 141-155. O „gościach” dworu Witolda zob. R. Petrauskas, Didžiojo kunigaikščio institucinio dvaro susiformavimas...

157 J. Purc, op. cit., s. 74-75.

158 CEV 1329, 1292.

159 Przywilej wielkiego księcia Aleksandra z 2 VII 1495 r.: „велики князь Витофтъ надалъ деду ихъ, на имя Близницу, подводъ не давати, ани корму и никоторыхъ подачокъ давати и (ни)какое службы не служити, для того, шо домъ ихъ на дорозе, и коли велики князь Витольдъ по дворахъ ездывалъ и в дому ихъ стоивалъ, а потомъ отецъ нашъ король его милость [Kazimierz Jagiellończyk - S.P.] далъ и сыномъ ихъ свой (листъ) по томужъ и в дому ихъ стоивалъ, а они подыймуютъ станцыею, ино и намъ ся пригодитъ коли в дому ихъ стояти", Акты, издаваемые Виленскою комиссиею для разбора древних актов, t. 24: Акты о боярах, Вильна 1897, nr 139, s. 218.

160 Вялікі гістарычны атлас Беларусі у 3-х тамах, t. 1, Мінск 2009, s. 124.

161 A. Gąsiorowski, I. Skierska, op. cit., s. 73-74; Gąsiorowski 2015, s. 26. 
w sytuacjach nagłych mogli poruszać się szybciej. Autor Latopisu wielkich książąt litewskich zauważył, że „князь великы Витовъть за одинь день приженеть из Городна ко отцю своему Кестутию”, gdy ten zajął Wilno i znalazł tam dokumenty potwierdzające kompromitujące Jagiełłę układy z zakonem ${ }^{162}$. Odległość między tymi dwoma miastami w linii prostej wynosi ok. $150 \mathrm{~km}$. Pokonanie takiej odległości, które w normalnych warunkach zajęłoby cztery dni, było tak niezwykłe, że Witold postanowił wspomnieć o tym w utworze pisanym faktycznie pod jego dyktando ${ }^{163}$. W sierpniu $1421 \mathrm{r}$. także niezwykle szybko pokonał $500 \mathrm{~km}$ dzielące Troki od Lublina. W 1429 r., podążając ze słynnego zjazdu monarchów w Łucku na Litwę ${ }^{164}$, pokonał drogę z Łucka do Turzyska w ciągu jednego dnia (najkrótsza droga na tym odcinku współczesnymi autostradami wynosi nieco mniej niż $80 \mathrm{~km}$ ).

Warto przypomnieć, że przytoczone dane dotyczą zachodniej części Wielkiego Księstwa Litewskiego, dobrze rozwiniętej pod względem gospodarczym i pokrytej siecią hospodarskich dworów i zamków. W przytoczonym dokumencie Aleksandra Jagiellończyka z 1495 r. mowa jest o dworach w okolicach Słonimia, po których jeździł Witold. Ale i tu nie unikano trudności. W listopadzie $1413 \mathrm{r}$. komtur bałgijski pisał do wielkiego mistrza, że miał jechać do Trok, do Witolda i Jagiełły, „bardzo ciężkimi drogami” ${ }^{165}$. Trzeba pamiętać, że podróż odbywała się jesienią, gdy trudno było posuwać się ze względu na zalegający śnieg. 24 sierpnia 1399 r. wielki mistrz pisał do Witolda, że zjazd z królem polskim jesienią lub zimą wydaje mu się niewygodny ze względu na złe drogi i wysoki śnieg ${ }^{166}$, natomiast zimą 1421/1422 r. poseł margrabiego brandenburskiego w ogóle nie zdołał z tej przyczyny dojechać do Jagiełły, przebywającego u Witolda ${ }^{167}$. Tak samo wiosną chan tatarski Uług Muchammed usprawiedliwiał brak swego udziału w niedawnej kampanii Świdrygiełły przeciwko Zygmuntowi Kiejstutowiczowi ${ }^{168}$. Te problemy stawały się bardziej widoczne na ziemiach wschodnich Wielkiego Księstwa Litewskiego, położonych daleko od centrum, z ich wielkimi odległościami i rzadką

162 ПСРЛ XXXV, s. 62; А.У. Ліцкевіч, Гародня і Гарадзенскі рэгіён у другой палове XIII-XIV стст. Сухапутныя і водныя камунікацыі..., s. 28.

163 Wiadomo, że goniec mógł pokonywać do $200 \mathrm{~km}$ dziennie, zajeżdżając przy tym konie; H. von Seggern, Herrschermedien im Spätmittelalter. Studien zur Informationsübermittlung im burgundischen Staat unter Karl dem Kühnen, Ostfildern 2003 (Kieler Historische Studien, t. 41), s. $108-109$.

164 CEV 1338.

165 „Am sontage nestvorgangen quomen wir ersten kegen Tracken, do wir die herren koning czu Polan und herczog Witoud haben derfolget gar in sweren wegen", GStAPK, OBA 2012.

$166, \ldots[\ldots]$ ist is nicht beqweme in dem herbiste ader in dem winter tage czu halden, wend di wege denne bose und tiff sin, das swer ustzutzien ist", CEV 201.

167 GStAPK, OBA 3647 = BGDO III 99.

168 O tym Świdrygiełło pisał do wielkiego mistrza zakonu krzyżackiego Paula von Rusdorf ze Smoleńska 3 V 1433 r.; oryg.: GStAPK, OBA 6430a; publ.: Н.М. Карамзин, История государства Российского, t. 5, Москва 1993, przyр. 264. 
siecią dworów i miast. Wyraźnie świadczy o tym list komtura Ragnety, który pomagał Witoldowi podczas wojny z Wasylem I, z 2 września 1406 r., wysłany z Briańska („, 56 mil dalej Dniepru”), gdzie znajdujemy barwny opis 17-dniowej drogi przez lasy briańskie i związane z tym trudności w otrzymywaniu jedzenia i koni ${ }^{169}$. W czasie tej samej wyprawy wojsko Witolda przez jeden odcinek z Kopysi do Orszy - pokonało nie więcej niż $26 \mathrm{~km}$, co mniej więcej odpowiada szybkości przemieszczenia wojsk znanej z innych źródeł ${ }^{170}$. Na problemy komunikacji spowodowane małą gęstością sieci osad wskazują miejsca wystawienia niektórych listów Witolda. Na początku wielkiego objazdu w 1427 r. pisał on do wielkiego mistrza „w naszym obozie w obiad, trzeciego dnia od Mińska”"171. Inny list, przypuszczalnie pochodzący z 1413 lub $1416 \mathrm{r}^{172}$, napisany został „na noclegu między Pińskiem a Lipskiem”, które dzieli odległość ok. 90 km. Znaczną rolę w systemie dróg Wielkiego Księstwa Litewskiego odgrywały rzeki ${ }^{173}$ : w ciepłe pory roku spływ nimi odbywał się znacznie szybciej niż po drogach lądowych ${ }^{174}$, natomiast zimą można było podróżować po ich zamrożonej powierzchni ${ }^{175}$.

Ekonomicznemu i organizacyjnemu zabezpieczeniu objazdów Witolda po jego władztwie służyła sieć dróg, dworów i grodów, a także system związanych z nimi powinności ludności: stacji (stanów) - dostarczanie żywności dla wielkiego księcia i jego otoczenia oraz obroku dla ich koni, podwód - zapewnienie środków transportu (powozów, sani, koni) dla wielkiego księcia, jego urzędników i gońców ( $w$ tym dostarczających korespondencję ${ }^{176}$ ) oraz towarzyszących mu zagranicznych władców i posłów, a także obowiązek budowy nowych i remontu starych dróg. Nie ma tu ani możliwości, ani konieczności analizowania licznych świadectw źródłowych o tych powinnościach, zostały one już zresztą opisane w literaturze ${ }^{177}$.

169 CEV 347.

170 Zob. np. А.У. Ліцкевіч, Гародня і Гарадзенскі рэгіён у другой палове XIII-XIV cmcm. Cyхапутныя і водныя камунікащььі..., s. 28; F. Ludwig, Untersuchungen über die Reise- und Marschgeschwindigkeit im XII. und XIII. Jahrhundert. I. Die Itinerare der deutschen Könige und Kaiser, der französischen Könige und der Päpste, Berlin 1897, s. 97.

171 CEV 1291.

172 CEV 385. O datacji zob. niżej, przyp. 276.

173 Gąsiorowski 2015, s. 23.

174 Otóż w październiku 1418 r., w przededniu zjazdu z wielkim mistrzem krzyżackim, Witold zakładał, że dopłynie Niemnem z Kowna do Pojeg (ok. 150 km) w ciągu jednego dnia (CEV 796, zob. także niżej pod tą datą).

175 Klimas 1933, s. 154.

176 O podwodach służących do dostarczania korespondencji hospodarskiej zob. LUB VIII 651; GStAPK, OBA 6291; ПГ I 140.

177 S. Wysłouch, Posługi komunikacyjne w miastach Wielkiego Księstwa Litewskiego na prawie magdeburskiem do połowy XVI wieku, Wilno 1936; J. Jurkiewicz, Powinności podwodowe włościan $w$ Wielkim Księstwie Litewskim (XVI-XVIII w.). Z zagadnień ich terminologii i klasyfikacji, w: Istorijos akiračiai, Vilnius 2004, s. 101-126; idem, „Podróże” chłopów Wielkiego Księstwa Litewskiego w XVI-XVIII w. (z zagadnień powinności transportowych włościan), w: „Młodsza Europa” od 
Warto zauważyć, że w różnych częściach Wielkiego Księstwa Litewskiego znany jest wiele „dróg Witoldowych”. Ponieważ są wspomniane zarówno we wczesnych, jak i późnych źródłach, a Witold nie był jedynym władcą, z którego imieniem tradycja łączyła te lub inne drogi ${ }^{178}$, to można uważać, że takie wzmianki nie są przypadkowe, stanowią nie tylko wynik późniejszej wizji przeszłości Wielkiego Księstwa w oczach jego mieszkańców, ale oddają też większą - ogólnopaństwową - skalę aktywności wielkiego księcia ${ }^{179}$.

Jak pokazują przytoczone dane, podróże Witolda do „dalekich ziem ruskich” Wielkiego Księstwa Litewskiego były przedsięwzięciem znacznie kosztowniejszym niż zwykłe przejazdy między zamkami i dworami Litwy właściwej. Gdy codzienne podróże Witolda po jego władztwie były dosyć regularne i służyły zaopatrzeniu wielkiego księcia i jego dworu, to te dalekie, na dużą skalę objazdy podejmowano sporadycznie, ich celem $\mathrm{w}$ znacznej mierze były kontakty hospodara z własnymi poddanymi, władcami państw sąsiednich i ich posłami. Objazdy te nie były reliktem przeszłości, lecz próbą wykorzystania sposobu „rządzenia objazdowego" w celu utwierdzenia i rozszerzenia swojej władzy na etapie między zniesieniem systemu księstw dzielnicowych na terenie Wielkiego Księstwa Litewskiego a przejściem do rządów rezydencjonalnych władcy tego państwa.

Gdybyśmy szukali analogii w krajach sąsiednich, to królestwo Mendoga możemy zestawić z Polską w XI-XII w., Wielkie Księstwo Litewskie pierwszych Giedyminowiczów z XIV w. - z Polską trzynastowieczną, natomiast państwo

średniowiecza do współczesności. Prace ofiarowane Profesor Marii Barbarze Piechowiak Topolskiej $w$ siedemdziesiąta rocznicę urodzin, red. J. Jurkiewicz, R.M. Józefiak, W. Strzyżewski, Zielona Góra 2008, s. 301-320; A. Szweda, Habitacula...; T. Čelkis, Stan dróg lądowych i struktura systemu połączeń $w$ Wielkim Księstwie Litewskim $w$ końcu XV-XVII wieku, ZH, t. 79, 2014, nr 3, s. 39-61; idem, „Valdovo keliai” Lietuvos Didžiosios Kunigaikštystès teritorinès struktūros sandaroje XV-XVI amžiuje, w: Lietuvos Statutas ir Lietuvos Didžiosios Kunigaikštystes bajoriškoji visuomenè, red. I. Valikonytė, L. Steponavičienè, Vilnius 2015, s. 247-259; G. Rutkowska, Stacje Jagiellonów na Litwie, w: Jagiellonowie i ich świat..., s. 187-195; ostatnio zob. T. Čelkis, Vieškeliu tinklo struktūra Lietuvos Didžiojoje Kunigaikštystèje XVI-XVII a., LIM, 2019, nr 1, s. 33-77.

178 Otóż koło Miadzioła, położonego niegdyś na obszarze Olgierdowego księstwa witebskiego, w 1495 r. istniała Olgierdowa droga; AGAD, Archiwum Radziwiłłów, dz. X, sygn. 383, k. 1-1v. Dobrze znane są wzmianki o drodze Dawidowej w ziemi grodzieńskiej oraz drogi Skumontowej koło Przewałki. Za tymi nazwami kryją się realne postacie kasztelana grodzieńskiego pierwszej połowy XIV w. Dawida Dowmontowicza i starosty Skomanta, który przeniósł się z Sudowii na Ruś; LM XXV, nr 76, 34, 109, s. 99, 133, 167; SRP I, s. 143, cap. 211.

179 Михалон Литвин, О нравах татар, литовиев и москвитян, орrac. А.Л. Хорошкевич, Москва 1994, s. 91, 136, przyp. 180; О. Белецкая, Имя великого князя литовского Витовта в названиях Северного Причерноморья XVI-XVIII веков, „Lietuvos istorijos studijos” 42, 2018, s. 7-25. Z drugiej strony, przynajmniej niektóre z takich nazw są wynikiem późniejszej wizji działalności Witolda: np. w czasach Stefana Batorego znany jest „погреб Витовтов” w Krzyczowie (RGADA, f. 389, op. 1, kn. 74, k. 65), chociaż miasto to za Witolda wchodziło w skład księstwa mścisławskiego Semena Lingwena. Czy nie jest to jednak związane z przedstawianiem postaci Witolda jako sławnego poprzednika Stefana Batorego? 
Witolda - z królestwem Kazimierza Wielkiego albo z państwami Europy Zachodniej wczesnego i późnego średniowiecza, których władcy (np. Karol Wielki ${ }^{180}$ ) opuszczali trzon swego władztwa w celu załatwienia bieżących spraw politycznych i militarnych ${ }^{181}$. W Wielkim Księstwie Litewskim nigdy nie powstało nic podobnego do przemyślanego systemu objazdów Królestwa Polskiego przez Władysława II Jagiełłę, który był ściśle związany z kalendarzem liturgicznym, albo w Świętym Cesarstwie Rzymskim - „imperium bez stolicy”.

180 A. Gauert, op. cit., s. 307-321.

181 Na tym, według K. Neitmanna (Neitmann 1990, s. 35, Anm. 76), polega różnica między tymi państwami a zakonem krzyżackim w okresie od połowy XIV do połowy XV w., ponieważ wielcy mistrzowie odwiedzali różne części swego władztwa mniej lub więcej regularnie, w ramach przyjętej przez nich praktyki sprawowania władzy. 


\section{Zasady zestawienia itinerarium}

W itinerarium przedstawionym $\mathrm{w}$ formie tabelarycznej (ze względu na charakter źródeł) wskazano przekazy źródłowe świadczące o pobycie Witolda w danym miejscu w określonym dniu. Przy tym opieram się na najbardziej pełnych, współczesnych i dokładnych edycjach źródeł: dla wydawnictw wielotomowych wskazywany jest na początku numer tomu cyframi rzymskimi, dalej cyframi arabskimi - numer dokumentu (dla ich zbiorów) lub strony/kolumny. Gwiazdka przy numerze oznacza regest, streszczenie. Kilka edycji tego samego zabytku łączono znakiem równania $(=)$. W przypadkach wykorzystania archiwaliów ich sygnatury podawane są na początku opisu.

Gdy Jan Długosz powtarza wiadomość zachowanego do dziś źródła, np. kroniki Wiganda z Marburga, albo jednego z wielu dokumentów, z których korzystał, to odwołanie do informacji Długoszowej jest podawane w nawiasach okrągłych po jej źródle.

Jeżeli Witold spotykał się z konkretnym władcą, ten fakt odnotowuje się z powołaniem się na najważniejszą literaturę.

Problem stanowi, jak wiadomo, rekonstrukcja itinerarium Witolda w czasie wojen. Nierzadko wzmianka źródłowa (np. „Witold zbudował zamek”) nie pozwala jednoznacznie wnosić, czy wielki książę uczestniczył w tej akcji osobiście, czy jedynie wydał odpowiedni rozkaz. Takie przypadki omówiono w przypisach. Przy rekonstrukcji itinerarium Witolda $\mathrm{w}$ czasie wojen $\mathrm{z}$ zakonem krzyżackim w latach 1409-1411, 1414 i 1422, w których uczestniczył on osobiście razem z królem polskim Władysławem Jagiełłą, priorytet nadawany jest źródłom, które zawierają bezpośrednie dane o miejscu pobytu Witolda. Warto bowiem pamiętać, że dostojnicy krzyżaccy starali się przekazywać taką informację w ramach struktur zakonnych jak najszybciej, często nie mając możliwości albo nie uważając za konieczne jej sprawdzenia. A tylko w przypadkach braku takich danych itinerarium Witolda jest umownie rekonstruowane na podstawie itinerarium Jagiełły; zresztą podczas wypraw do Prus bracia stryjeczni niekoniecznie musieli sobie nieustannie towarzyszyć. Nie uwzględniam danych o miejscach pobytu żon Witolda, ponieważ małżonkowie mogli podróżować oddzielnie ${ }^{182} . \mathrm{Z}$ reguły nie przenoszę na itinerarium Witolda danych o miejscach pobytu posłów do

182 Na przykład latem 1400 r. Anna Witoldowa udała się do Prus w towarzystwie Zygmunta Kiejstutowicza; Т.Ю. Игошина, op. cit., s. 179-181; A. Nowakowski, Księżna Anna Witoldowa a Krzyżacy, w: Archaeologia et historia. Ksiega jubileuszowa dedykowana Pani Profesor Romanie Barnycz-Gupieńcowej, Łódź 2000, s. 292-294; SRP II, s. 331 (Anm.); o sąsiedniej Polsce zob. A. Gąsiorowski, Polskie itineraria późnośredniowieczne..., s. 223-226; G. Rutkowska, Podróże polskich królowych w XV wieku, w: Samotrzeć, w kompanii czy z orszakiem? Społeczne aspekty podróżowania w średniowieczu i w czasach nowożytnych, red. M. Saczyńska, E. Wółkiewicz, Warszawa 2012, s. 175-197 (w tych pracach podsumowanie szczegółowych badań). 
niego: znany jest niejeden przykład rozbieżności itinerariów posła krzyżackiego i władcy litewskiego ${ }^{183}$.

Nie mam wątpliwości, że inercja i przywiązanie do narodowych tradycji historiograficznych zaważą też na badaniu problematyki podróży wielkich książąt litewskich po ich władztwie. Dlatego też, ale również dla ułatwienia pracy z poniższym itinerarium poprawki do prac Jerzego Purca i Jana Tęgowskiego są odnotowywane i objaśniane w przypisach.

183 Zob. np. GStAPK, OBA $2012=$ CEV 567* (sprawozdanie komtura Bałgi z 23 XI 1413 r., pisane w Rumszyszkach, w drodze powrotnej od Witolda); GStAPK, OBA 5873, 5875 (17 XII 1431 r. Świdrygiełło przebywał w Wiszniewie, ojcowiźnie Giedygołda, natomiast poseł krzyżacki Gabriel von Baysen (Bażyński) - w Holszanach); С.В. Полехов, Наследники Витовта..., s. 220. 


\begin{tabular}{|c|c|c|c|c|}
\hline \multicolumn{2}{|c|}{ Data } & Miejsce & Źródło & Uwagi \\
\hline \multicolumn{5}{|c|}{1392} \\
\hline VII & & Ritterswerder ${ }^{184}$ & $\begin{array}{l}\text { SRP II, s. } 648 \text { (Dług. X, } \\
\text { s. 196) }\end{array}$ & \\
\hline VIII & $4 / 5^{185}$ & Ostrów & AUPL 29 & \\
\hline VIII & & Wilno (?) ${ }^{186}$ & Dług. X, s. 197 & \\
\hline \multicolumn{2}{|c|}{ jesień? } & Smoleńsk (?) & $\begin{array}{l}\text { ПСРЛ IV/1, s. } 373 ; \\
\text { ПСРЛ VI/1, s. 509- } \\
-510^{187}\end{array}$ & \\
\hline XII & 6 & Bełz & $\begin{array}{l}\text { BCz, perg. } 236= \\
\text { CESXV I } 20^{188}=\text { CEV } 98^{\star}\end{array}$ & \\
\hline \multicolumn{5}{|c|}{1393} \\
\hline \multirow[t]{2}{*}{ I } & & Dokudowo $^{189}$ & ПСРЛ ХХХV, s. 71 & \\
\hline & & Nowogródek & ПСРЛ ХХХV, s. 71 & \\
\hline II & 6 & Nowogródek & Vitoldiana 10 & \\
\hline
\end{tabular}

${ }^{184}$ Krótko istniejący zamek wzniesiony przez Krzyżaków przy Niemnie, na zachód od Kowna.

${ }^{185}$ Dokumenty ugody ostrowskiej mają datę: „Actum et datum in Ostrowo ipsa die sancti Dominici” 1392 r. Wydawcy AUPL pierwotnie datowali je na 4 sierpnia, później jednak poprawili tę datę na $5 \mathrm{tm}$. (AUPL, s. 401), ponieważ upamiętnienie św. Dionizego obchodzono zarówno 4, jak i 5 sierpnia. U Długosza, który opierał się na tych samych dokumentach, błędna data 7 sierpnia (Dług. X, s. 197). Nie do końca jasna pozostaje lokalizacja Ostrowa (zob. indeks geograficzny).

186 Wiemy, że źródłem wiedzy Długosza o wydarzeniach z 1392 r. był przekład łaciński kroniki Wiganda z Marburga i szereg dokumentów (w tym wypadku ugoda ostrowska). Jednak nie zawierają one żadnych danych o wizycie Jagiełły i Witolda w Wilnie, tak samo jak i inne współczesne źródła; por. Gąsiorowski 2015, s. 43. Bardzo prawdopodobne, że źródłem informacji był patron Długosza, biskup krakowski Zbigniew Oleśnicki - syn „starosty litewskiego” Jana (Jaśka) Oleśnickiego, który według Długosza przekazał rządy Witoldowi w Wilnie po ugodzie ostrowskiej; A. Kornecka-Trafas, Oleśnicki Jan, w: PSB, t. 23, Wrocław 1978, s. 763-764. Z drugiej strony ustalenie źródła informacji nie gwarantuje jeszcze jej wiarygodności, zwłaszcza że już 10 sierpnia Jagiełło jest poświadczony w Żukowie, w odległości niemal $500 \mathrm{~km}$ od Wilna, a więc nie mógł z Ostrowa udać się do Wilna, by wziąć udział w jakichś ceremoniach (bez jego udziału raczej by się one nie odbyły); zob. Gąsiorowski 2015, s. 43, przyp. 34 .

187 W latopisach grupy nowogrodzko-sofijskiej spotkanie Witolda z Wasylem I i Zofią Witoldówną odnotowano przed nadanem Witoldowi przez Jagiełłę „в Литовской земле княжения великого" (oba wydarzenia - pod 6901 r.). Ponieważ wcześniej Witold był w Prusach, kolejność wydarzeń musiała być odwrotna. Na podstawie itinerarium Witolda datuję to wydarzenie między sierpniem a początkiem grudnia $1392 \mathrm{r}$.

${ }^{188}$ W edycji przygotowanej na podstawie osiemnastowiecznego odpisu data została zniekształcona.

189 Według Starszej kroniki wielkich mistrzów walka Witolda z Korybutem pozwoliła komturom Dzierzgonia i Ostródy spalić Grodno; SRP III, s. 623-624. Według annalisty toruńskiego i oficjała pomezańskiego nastąpiło to w początkach stycznia 1393 r.; SRP III, s. 185; SRP II, s. 649. Tekst Długosza w tym wypadku jest nieudanym skróceniem kroniki Wiganda; Dług. X, s. 198-199. 


\begin{tabular}{|c|c|c|c|c|}
\hline \multicolumn{2}{|c|}{ Data } & Miejsce & Źródło & Uwagi \\
\hline \multirow{3}{*}{\multicolumn{2}{|c|}{$\begin{array}{l}\text { między } 6 \text { II } \\
\text { a } 27 \text { IV }^{190}\end{array}$}} & Druck & ПСРЛ ХХХУ, s. 71 & \\
\hline & & Orsza & ПСРЛ ХХХV, s. 71 & \\
\hline & & Witebsk & $\begin{array}{l}\text { ПСРЛ ХХХV, s. 71-72; } \\
\text { SRP III, s. } 185\end{array}$ & \\
\hline VIII & 15 & $\begin{array}{l}\text { wyspa na rzece } \\
\text { Dubissie }\end{array}$ & SRP III, s. 625 & \\
\hline $\mathrm{X}$ & 3 & $\begin{array}{l}\text { Lwów } \\
(\text { Leony })^{191}\end{array}$ & CESXV II, dod. 1 & \\
\hline \multicolumn{5}{|c|}{1394} \\
\hline II & 18 & Dolatycze & AUPL 35 & \\
\hline \multicolumn{2}{|c|}{ wiosna } & Jurbork & $\begin{array}{l}\text { SRP II, s. } 653 \text { (Dług. X, } \\
\text { s. 204) }\end{array}$ & \\
\hline \multirow{3}{*}{\multicolumn{2}{|c|}{ wiosna }} & Podole $^{192}$ & ПСРЛ ХХХХ, s. 65, 72 & \\
\hline & & Żytomierz & ПСРЛ ХХХХ, s. 65, 72 & \\
\hline & & Owrucz & ПСРЛ ХХХV, s. 65, 72 & \\
\hline VI & $8-11$ & Nowy Korczyn & RD, s. $240-242$ & \\
\hline \multicolumn{2}{|c|}{$\begin{array}{l}\text { między } 11 \text { VI } \\
\text { a } 17 \text { VIII }^{193} \text { lub mię- } \\
\text { dzy } 21 \text { IX a } 11 \text { X (?) }\end{array}$} & Kijów & ПСРЛ ХХХV, s. 65, 72 & \\
\hline VIII & 17 & Ritterswerder ${ }^{194}$ & $\begin{array}{l}\text { SRP II, s. 656; SRP III, } \\
\text { s. 193-194 }\end{array}$ & $\begin{array}{l}\text { starcie Witolda } z \text { wielkim } \\
\text { mistrzem krzyżackim } \\
\text { (Neitmann } 1990, \text { s. } 68)\end{array}$ \\
\hline VIII & 29 & Rudomino & SRP III, s. 194-195 & \\
\hline
\end{tabular}

190 O chronologii wydarzeń i ocenie źródeł do jej ustalenia zob. Полехов 2018.

191 W sprawie identyfikacji zob. G. Rutkowska, Itinerarium królowej Jadwigi 1384-1399, w: Dzieło Jadwigi i Jagiełly. W sześćsetlecie chrztu Litwy i jej związków z Polską, Warszawa 1989, s. 215 i przyp. 67.

192 Informacje podane w Latopisie wielkich książąt litewskich odnoszę do wyprawy Witolda na Kijowszczyznę wiosną 1394 r., ponieważ jeszcze w oficjalnym dokumencie w lutym 1394 r. Włodzimierz Olgierdowicz nosi tytuł księcia kijowskiego (AUPL 35), narracja w latopisie umieszcza wyprawy na Podole, Kijowszczyznę i znowu Podole w tym samym roku, a z dokumentów wiadomo, że Podole zostało zajęte przez Witolda pod koniec $1394 \mathrm{r}$. Na tej podstawie datuję dokument Witolda dla monasteru Ławryszewskiego wydany w Bersztach i oznaczony indykcją 2 (Мікульскі 2014, s. 128, nr 1) na 1409 albo 1424 r.

193 Narrację w latopisie o „posadzeniu na Kijowie” Skirgiełły przez Witolda, nawet przy jej możliwej tendencyjności, można zestawić z itinerarium Skirgiełły: po długim pobycie na dworze królewskim po raz ostatni został on wspomniany pod 8 VI 1394 r. (RD, s. 200), natomiast pod koniec roku, według Latopisu wielkich książąt litewskich, brał aktywny udział w zbrojnym zajęciu Podola.

${ }^{194}$ Krótko istniejący zamek wzniesiony przez Krzyżaków nad Niemnem na zachód od Kowna. 


\begin{tabular}{|c|c|c|c|c|}
\hline \multicolumn{2}{|c|}{ Data } & Miejsce & Źródło & Uwagi \\
\hline \multicolumn{2}{|c|}{29 VIII-21 IX } & koło Wilna & SRP III, s. 195 & \\
\hline $\mathrm{X}$ & 11 & Chełm & Tęgowski 1997, dod. 2 & \\
\hline \multicolumn{2}{|c|}{ po $11 \mathrm{X}$} & Podole ${ }^{195}$ & ПСРЛ ХХХV, s. 72 & \\
\hline \multicolumn{5}{|c|}{1395} \\
\hline II & $2(?)$ & Wilno & KDKW 25 & \\
\hline VI & $\begin{array}{l}17 \text { i póź- } \\
\text { niej }\end{array}$ & $\begin{array}{l}\text { nad rzeką } \\
\text { Dubissą }\end{array}$ & $\begin{array}{l}\text { SRP III, s. 199; CDP VI } \\
\text { 20, 21; LUB IV } 1377\end{array}$ & $\begin{array}{l}\text { zjazd z mistrzem inflanckim } \\
\text { (Kubon 2016, s. 68-70) }\end{array}$ \\
\hline IX & 28 & Smoleńsk ${ }^{196}$ & ПСРЛ IV/1, s. 379 & \\
\hline \multicolumn{5}{|c|}{1396} \\
\hline II & 24 & Dubicze (?) & Vitoldiana $86^{197}$ & \\
\hline III & koniec & Smoleńsk & & $\begin{array}{l}\text { spotkanie z Wasy- } \\
\text { lem I i metropolitą Cypria- } \\
\text { nem, ten ostatni na Wiel- } \\
\text { kanoc konsekrował biskupa } \\
\text { smoleńskiego Nasona }\end{array}$ \\
\hline IV & 2 & Smoleńsk & ТЛ, s. $447^{198}$ & \\
\hline
\end{tabular}

195 J. Purc za Długoszem (Dług. X, s. 204) datuje na zimę 1394 r. wyprawę Witolda na Wystruć w Prusach. Jednak podstawą takiego stwierdzenia kanonika krakowskiego był Wigand $\mathrm{z}$ Marburga (Rozbiór krytyczny Annalium Poloniae Jana Długosza z lat 1385-1444, t. 1, Wrocław-Warszawa-Kraków 1961, s. 41), który w podał informację o wiosennej wyprawie Witolda na Jurbark (SRP II, s. 653).

196 Nowogrodzki I latopis i zbiór twerski mówią o wyprawie Witolda na ziemię riazańską zimą 1395/1396 r., natomiast nowogrodzki IV latopis i moskiewski zwód latopisarski z końca XV w. o tym, że wysłał tam wojsko; НПЛ, s. 388; ПСРЛ IV/1, s. 380; ПСРЛ ХV, kol. 457; ПСРЛ ХХV, s. 226.

197 Dokument dla namiestnika brzeskiego Twirbuta o nadaniu „ляху Якушу” „пустыни у Корошове от парчовское границы за Берестьем" na podstawie 4 indykcji można datować na 1396, 1411 lub 1426 r.; H. Gmiterek, Protokół komisji granicznej polsko-litewskiej z 1623 roku, „Res Historica” 21, 2005, s. 131. Ponieważ w 1416 r. cmethones et villani z sąsiedniego Woinia pozywali Jakusza do sądu królewskiego, oskarżając go o zagarnięcie ich ziem (zob. A. Wilkiewicz-Wawrzyńczykowa, Spory graniczne polsko-litewskie w XV-XVII w., „Wiadomości. Studium Historii Prawa Litewskiego" 1, (Wilno) 1938, s. 115; A. Wawrzyńczyk, Rozwój wielkiej własności na Podlasiu w XV i XVI wieku, Wrocław 1951, s. 18-19) to najbardziej możliwa wydaje się datacja 14 II 1396 lub 5 III $1411 \mathrm{r}$.

198 J. Purc odnosi pobyt Witolda w Smoleńsku także do ok. 19 III 1396 r., powołując się na: F. Koneczny, Dzieje Rosyi, t. 1, Warszawa 1917, s. 424. Ten zaś najprawdopodobniej błędnie odniósł początek zdania o ich wyjeździe z Moskwy już do pobytu w Smoleńsku: „Toe же весны за двъ недъли до велика дни князь великіи Василеи Дмитріевичь поъха въ Смоленскъ, тако же и Кипріанъ митрополитъ...” Dwa tygodnie wystarczyły na dojazd z Moskwy do Smoleńska; С. Герберштейн, Записки о Московии, t. 2, Москва 2008, s. 511. Ponieważ latopis słucki informuje, że Wasyl I przybył do Smoleńska „тое ж зимы на весну” і „у велики пост” (ПСРЛ XXXV, s. 72), nastąpiło to jeszcze przed Wielkanocą, czyli pod koniec marca, bo wiosnę wtedy 


\begin{tabular}{|c|c|c|c|c|}
\hline \multicolumn{2}{|c|}{ Data } & Miejsce & Źródło & Uwagi \\
\hline \multicolumn{2}{|c|}{ między 2 IV a $21 \mathrm{~V}$} & koło Wizny & SRP III, s. 205, 211 & \\
\hline $\mathrm{V}$ & 15 & Merecz & $\begin{array}{l}\text { KDKW 26; Antanavičius } \\
\text { 1994, s. 141-146 }\end{array}$ & \\
\hline VI & 20 & Janczyn & $\begin{array}{l}\text { CEV } 126 \text { = Vitoldiana } \\
199=\text { A3P II, nr I-157 }\end{array}$ & \\
\hline VII & $3(?)$ & Euck & AS I 20 & \\
\hline VII & $22-28$ & $\begin{array}{l}\text { nad rzeką } \\
\text { Dubissą }\end{array}$ & $\begin{array}{l}\text { SRP III, s. 204-206; } \\
\text { CDP V 83; BGDO I } 246\end{array}$ & $\begin{array}{l}\text { zjazd z wielkim mistrzem } \\
\text { krzyżackim (Kubon 2016, } \\
\text { s. 71-73) }\end{array}$ \\
\hline VII & 28 & Stare Kowno & $\begin{array}{l}\text { LUB IV } 1422=\text { CEV } \\
128^{*}\end{array}$ & \\
\hline IX & $17(?)$ & Miedniki & Vitoldiana 66 & \\
\hline \multicolumn{2}{|c|}{ ok. $1 \mathrm{X}$} & $\begin{array}{l}\text { ziemia riazań- } \\
\text { ska }\end{array}$ & ПСРЛ XXV, s. 227 & \\
\hline \multicolumn{2}{|c|}{ po $1 \mathrm{X}$} & Kołomna & ПСРЛ ХХV, s. 227 & spotkanie z Wasylem I \\
\hline \multicolumn{5}{|c|}{1397} \\
\hline \multirow[t]{3}{*}{ I } & $16^{199}$ & Grodno (plan) & $\mathrm{CDP}$ VI $34=\mathrm{CEV} 137^{*}$ & \\
\hline & 23 & $\begin{array}{l}\text { na łowach } \\
4 \text { mile od } \\
\text { Wilna }^{200} \\
\end{array}$ & ПГ І 36 = CEV 139* & \\
\hline & 30 & Wilno & ПГ І 37 = CEV $144^{*}$ & \\
\hline III & 28 & Dubicze & CEV 148 & \\
\hline \multirow[t]{2}{*}{ V } & 13 & Litwa (?) & CDP V 99; VI 39 & \\
\hline & 20 & Lida & KDKW 30 & \\
\hline
\end{tabular}

liczono do 24 marca. Latopis archangielski z początku XVI w. błędnie podaje, że Wasyl I przebywał w Smoleńsku „двъ недъли мъсяца февраля”; Г. Бугославский, Сокращенная Литовская летопись начала XVI в., w: Смоленская старина, t. 1, cz. 2, Смоленск 1911, s. 14-15; szerzej zob. А.У. Ліцкевіч, Пра некаторыя спісы „Летапісиз вялікіх князёу літоўскіх” маскоўскага інаугародскага паходжання (на маргінезе выданняў М. Улашчыка і В. Вароніна), w: Вялікае княства Літоўскае і яго суседзі ў XIV-XV стст. Саперніцтва, супрацойніцтва, урокі, Мінск 2011, s. 211-212. Dalej J. Purc odnotowuje pobyt Witolda w Kownie w kwietniu 1396 r., ale jego wskazówki prowadzą do listu (SD I 661), który w rzeczywistości odnosi się do $1418 \mathrm{r}$. (CEV 766).

199 J. Purc za A. Prochaską rozumie datę „von dem nesten dinstag [9 I - S.P.] obir acht tage” jako 15 I 1397 r. Jednak osiem dni, występujące w tej formule średniowiecznej, obejmowały zarówno pierwszy, jak i ostatni dzień tego terminu; zob. H. Grotefend, Zeitrechnung des deutschen Mittelalters und der Neuzeit, t. 1, Hannover 1891 http://bilder.manuscripta-mediaevalia.de/gaeste// grotefend/g_a.htm (dostęp: 9 X 2019).

200 J. Purc odnotowuje pobyt Witolda w Einsiedlu 26 I 1397 r. Jednak dokument, na który się powołuje $\left(\mathrm{CEV} 141^{\star}\right)$, został wystawiony nie przez Witolda, lecz przez wielkiego mistrza. 


\begin{tabular}{|c|c|c|c|c|}
\hline \multicolumn{2}{|c|}{ Data } & Miejsce & Źródło & Uwagi \\
\hline \multicolumn{2}{|c|}{ między IX a XII (?) } & $\begin{array}{l}\text { za Donem } \\
(?)^{201} \\
\text { Nadczarno- } \\
\text { morze } \\
\text { północne (?) }\end{array}$ & $\begin{array}{l}\text { Dług. X, s. 221; SRP III, } \\
\text { s. } 216\end{array}$ & $\begin{array}{l}\text { wyprawa na pomoc } \\
\text { Tochtamyszowi }\end{array}$ \\
\hline \multicolumn{2}{|l|}{ zima } & Litwa (?) & ПСРЛ ХХV, s. 227 & \\
\hline \multicolumn{5}{|c|}{1398} \\
\hline \multirow[t]{4}{*}{ IV } & 6 & Troki (?) & Полехов 2018, nr $1^{202}$ & \\
\hline & 7 & Litwa (?) & CEV 176 & \\
\hline & 19 & Grodno & LUB IV $1469^{203}$ & \\
\hline & $21-23$ & Grodno & LUB IV 1469; SVDO I 1 & $\begin{array}{l}\text { zjazd z wielkim mistrzem } \\
\text { krzyżackim (Kubon 2016, } \\
\text { s. } 94-100)\end{array}$ \\
\hline \multicolumn{2}{|l|}{ lato } & $\begin{array}{l}\text { zamek (twier- } \\
\text { dza) św. Jana } \\
\text { nad Dnieprem }\end{array}$ & SRP III, s. 222 & $\begin{array}{l}\text { wyprawa na pomoc } \\
\text { Tochtamyszowi }\end{array}$ \\
\hline \multirow[t]{2}{*}{$\mathrm{X}$} & $4 / 5-12$ & Wyspa Salin ${ }^{204}$ & $\begin{array}{l}\text { GStAPK, OBA 567; } \\
\text { SVDO I 2; SRP III, } \\
\text { s. } 222-224\end{array}$ & $\begin{array}{l}\text { zjazd z wielkim mistrzem } \\
\text { krzyżackim (Kubon 2016, } \\
\text { s. 100) }\end{array}$ \\
\hline & 14 & Kowno & SVDO I 3 & \\
\hline \multicolumn{2}{|c|}{ po $14 \mathrm{X}$} & Grodno & SRP III, s. 224 & \\
\hline \multicolumn{5}{|c|}{1399} \\
\hline \multirow[t]{2}{*}{ I } & 27 & Holszany & ПГ І 38 & \\
\hline & 31 & Krewo & HUB V 364 & \\
\hline II & 2 & Mołodeczno & HUB V 365 & \\
\hline III & $2-6$ & Połock & $\begin{array}{l}\text { HUB V } 364 \text { (plan); } \\
\text { ПГ I } 39\end{array}$ & \\
\hline
\end{tabular}

201 Wyprawę na pomoc Tochtamyszowi, o której wspominają Długosz i kronikarze lubeccy, odnoszę do września-grudnia 1397 r. na tej podstawie, że Witold w tym czasie pozostawiał bez odpowiedzi listy wielkiego mistrza Konrada von Jungingen, którego niedługo przed 7 września odwiedził poseł wielkoksiążęcy - pisarz Piotrasz; CEV 163; Kubon 2016, s. 88-90. J. Purc odnotowuje pobyt Witolda w Nowogródku 8 XI 1397 r., jednak przywołany przezeń list (CEV 167) nie ma daty rocznej i zapewne powstał pod koniec pierwszej dekady XV w.; ПГ I 29; ПГ II, s. 46-47 (kom. S.P.).

${ }^{202}$ Możliwa też datacja dokumentu na 6 IV 1409 albo (mniej prawdopodobne) 1420 r. - zob. wskazany artykuł.

${ }^{203}$ O datacji listu zob. Kubon 2016, s. 93, Anm. 337.

204 Oficjał pomezański datuje zjazd „uf sente Michelis”, czyli 29 IX 1398 r. (SRP III, s. 220), jednak $\mathrm{z}$ brulionu listu wielkiego mistrza do Witolda (GStAPK, OBA 567) wiadomo, że na prośbę wielkiego księcia zjazd został odroczony do początku października. 


\begin{tabular}{|c|c|c|c|c|}
\hline \multicolumn{2}{|c|}{ Data } & \multirow{2}{*}{\begin{tabular}{|l} 
Miejsce \\
Smoleńsk
\end{tabular}} & \multirow{2}{*}{\begin{tabular}{|l|}
\multicolumn{1}{|c|}{ Źródło } \\
HUB V 364 (plan); \\
ПСРЛ ХХV, s. 228 \\
\end{tabular}} & \multirow{2}{*}{$\begin{array}{l}\text { Uwagi } \\
\text { spotkanie z Zofią } \\
\text { Witoldówną }\end{array}$} \\
\hline & $\begin{array}{l}\text { między } 6 \\
\text { a } 30\end{array}$ & & & \\
\hline & po 30 & $\begin{array}{l}\text { Litwa (Jur- } \\
\text { bork?) }\end{array}$ & MTB, s. 39-40 & $\begin{array}{l}\text { zjazd } \mathrm{z} \text { wielkim mistrzem } \\
\text { krzyżackim }\end{array}$ \\
\hline IV & 3 & Troki & KDKW 36 & \\
\hline VI & & Kijów 205 & Dług. X, s. 226 & \\
\hline \multicolumn{2}{|c|}{ VI-VII } & Łuck & $\begin{array}{l}\text { LVVA, f. } 673 \text {, apr. } 4 \text {, } \\
\text { k. } 18 \text {, nr } 80^{206}\end{array}$ & \\
\hline \multirow[t]{2}{*}{ VII } & $\begin{array}{l}\text { pierwsza } \\
\text { połowa } \\
\text { lub } \\
\text { połowa? }\end{array}$ & Kraków & $\begin{array}{l}\text { CEV 201; Dług. X, } \\
\text { s. } 236^{207}\end{array}$ & \\
\hline & $\begin{array}{l}\text { druga } \\
\text { połowa }\end{array}$ & $\begin{array}{l}\text { przeprawa } \\
\text { przez Dniepr, } \\
\text { Sułę i Pseł }\end{array}$ & Dług. X, s. $226^{208}$ & \\
\hline VIII & $\begin{array}{l}5-12(14 ? \\
16 ?)^{209}\end{array}$ & $\begin{array}{l}\text { nad rzeką } \\
\text { Worsklą }\end{array}$ & $\begin{array}{l}\text { SRP III, s. 229-230; } \\
\text { Dług. X, s. 226-229; } \\
\text { НПЛ, s. 394-395 }\end{array}$ & \\
\hline \multicolumn{2}{|c|}{ po $12 \mathrm{VIII}$} & Litwa & Dług. X, s. 236 & \\
\hline
\end{tabular}

205 Według S.C. Rowella główne siły Witolda wyruszyły z Wilna po Zielonych Świątkach, obchodzonych 19 maja, na tę datę starcia wskazuje lubecki kronikarz Detmar; SRP III, s. 229; S.C. Rowell, op. cit., s. $70,75$.

${ }^{206}$ W tym liście z 25 lipca Klaus Riman donosił władzom Rygi z Połocka: „Wiedzcie, panowie i mili przyjaciele, że Połocczanie wrócili z wyprawy, na której byli z księciem Witoldem, a książę Witold udał się w stronę Łucka” („Wetet, heren unde leven vrunde, wo de Ploschowers sid ut der reise comen, dar ze myt Vitoweten weren, und hertoghe Vitowe is to Lůtsche werd hen ghetoghen"; tłum. S.P.). Na końcu pisma podano, że Witold zbudował dwie twierdze w odległości 2 dni drogi od Kaffy (Krymu?) nad rzeką Boh (? Bochowe Rekkee). Prawdopodobnie sam wielki książę w tej akcji nie uczestniczył.

207 Odpowiedź wielkiego mistrza Konrada von Jungingen na poselstwo Piotrasza, pisarza Witoldowego, wysłane z Krakowa, gdzie Witold przyjechał do króla. Ponieważ Jagiełło poświadczony jest w Krakowie 3 i 19 VII 1399 r., wcześniej zaś przebywał w Wiślicy i Nowym Korczynie, ok. 70-80 km na północny wschód od Krakowa (Gąsiorowski 2015, s. 51), a odległość między Krakowem a Worsklą wynosi nie mniej niż 1200 km, to wizyta Witolda w Krakowie mogła mieć miejsce nie później niż w połowie lipca. Długosz łączy przyjazd Witolda do Krakowa z pogrzebem królowej Jadwigi, który odbył się 19 VII 1399 r.

208 U Długosza: „Dum itaque fluviis Nyepr «Szimna Voda, Pszlo [dopełnienia Długosza na marginesie autografu - S.P.]» et Sula superatis”. Nie udaje się zidentyfikować rzeki Szimna Voda.

209 W literaturze jako datę bitwy nad Worsklą zwykle podaje się 12 VIII 1399 r. Jednak źródła są rozbieżne pod tym względem: Długosz waha się pomiędzy 12 a 14 sierpnia, natomiast źródło współczesne - rocznik świętokrzyski - podaje 16 sierpnia; Rocznik świętokrzyski, wyd. A. Rutkowska-Płachcińska, Kraków 1996 (Monumenta Poloniae Historica. Nova series, t. 12), s. 73-74; zob. S.C. Rowell, op. cit., s. 68, 78-79. 


\begin{tabular}{|c|c|c|c|c|}
\hline \multicolumn{2}{|c|}{ Data } & Miejsce & Źródło & Uwagi \\
\hline \multicolumn{2}{|l|}{ IX } & Litwa (?) & MTB, s. 31 & \\
\hline \multicolumn{2}{|l|}{$\mathrm{X}-\mathrm{XI}$} & Litwa (?) & MTB, s. 35, 36 & \\
\hline \multicolumn{2}{|l|}{ XII } & Litwa (?) & MTB, s. 59 & \\
\hline \multicolumn{5}{|c|}{1400} \\
\hline I & 10 & $\begin{array}{l}\text { Litwa (Wil- } \\
\text { no? })^{210}\end{array}$ & $\begin{array}{l}\text { CDP VI 92, s. 94-95; } \\
\text { MTB, s. } 66\end{array}$ & \\
\hline II & & $\begin{array}{l}\text { Żmudź (Kroże } \\
\text { etc.) }\end{array}$ & $\begin{array}{l}\text { SRP III, s. 235-236; } \\
\text { CDP VI } 96\end{array}$ & \\
\hline III & początek & Troki & $\begin{array}{l}\text { GStAPK, OBA } 602,603 \\
\text { MTB, s. } 57^{211}\end{array}$ & \\
\hline IV-V & & Litwa (?) & MTB, s. 72-74 & \\
\hline \multirow[t]{2}{*}{$\mathrm{X}$} & początek & Litwa (?) & MTB, s. 85 & \\
\hline & 23 & Połock & ПГ I 41 & \\
\hline XII & 31 & $\begin{array}{l}\text { nad jez. Kruda } \\
\text { między Grod- } \\
\text { nem a Mere- } \\
\text { czem (?) }\end{array}$ & AUPL 36 & \\
\hline \multicolumn{5}{|c|}{1401} \\
\hline \multirow[t]{2}{*}{ I } & 18 & Wilno & AUPL 38 & \\
\hline & 26 & Birsztany (?) & AUPL 40 & \\
\hline \multirow[t]{3}{*}{ II } & 4 & Merecz & ПГ І 42 = CEV 235* & \\
\hline & 12 & Merecz (?) & AUPL 41 & \\
\hline & 24 & Troki (?) $)^{212}$ & AUPL 42,43 & \\
\hline III & 20 & Wilno & CEV 238 & \\
\hline \multicolumn{2}{|c|}{ III-IV (?) } & $\begin{array}{l}\text { Kowno, nad } \\
\text { rzeką Wiliąą }\end{array}$ & SRP III, s. 247 & \\
\hline
\end{tabular}

${ }^{210}$ J. Purc odnotowuje pobyt Witolda w Wilnie w tym dniu, powołując się na pracę: M. Goyski, Wzajemne stosunki Polski, Litwy i Zakonu w latach 1399-1404, Kraków 1906, s. 10, gdzie z kolei odsyłacz do wskazanego źródła - listu Jagiełły do wielkiego mistrza. Na fakt, że Witold przebywał na Litwie (może w Wilnie) wskazują słowa Jagiełły, że list został mu dostarczony przez pisarza Witoldowego Piotra; por. Gąsiorowski 2015, s. 52. Ten ostatni był w Prusach w grudniu 1399 r., następnie - w styczniu 1400 r.; MTB, s. 59, 66.

211 Poselstwo do Witolda; dokładnie wskazane miejsce przeznaczenia.

212 O pobycie Witolda na Litwie w lutym pośrednio świadczy także to, że w początkach marca jego posłowie - bojar Czupurna i pisarz Piotrasz - przebywali w Elblągu (MTB, s. 108); wysłanie tam posłów oznacza, że wielki książę przebywał stosunkowo niedaleko od Prus.

${ }^{213}$ Nie sposób dokładnie datować informacji oficjała pomezańskiego o pobycie Witolda z oddziałem polskim w Kownie. Zapewne do jego wysłania doszło w marcu, gdy został zatwierdzony układ wileńsko-radomski, a na Żmudzi wybuchło powstanie inspirowane przez Witolda; 


\begin{tabular}{|c|c|c|c|c|}
\hline \multicolumn{2}{|c|}{ Data } & \multirow{2}{*}{\begin{tabular}{|l} 
Miejsce \\
Litwa (?) \\
\end{tabular}} & \multirow{2}{*}{\begin{tabular}{|l|}
\multicolumn{1}{|c}{ Źródło } \\
MTB, s. 111 \\
\end{tabular}} & \multirow[t]{2}{*}{ Uwagi } \\
\hline IV & & & & \\
\hline \multicolumn{2}{|c|}{ jesień } & $\begin{array}{l}\text { pod Smoleń- } \\
\text { skiem }\end{array}$ & ПСРЛ IV/1, s. 390-391 & oblężenie przez 4 tygodnie \\
\hline \multicolumn{2}{|c|}{ jesień (ok. $21 \mathrm{X} ?{ }^{214}$ ) } & $\begin{array}{l}\text { pod Nowogro- } \\
\text { dem Wielkim }\end{array}$ & SRP III, s. 250 & oblężenie przez 3 tygodnie \\
\hline \multicolumn{5}{|c|}{1402} \\
\hline I & 29 & Kraków & NKRMK, s. $269^{215}$ & $\begin{array}{l}\text { udział w uroczystościach } \\
\text { ślubnych Władysława Jagiełły } \\
\text { (Gąsiorowski 2015, s. 54) }\end{array}$ \\
\hline III & 1 & Dubicze (?) & ПГ І 43 & \\
\hline VI & & $\begin{array}{l}\text { pod Gotteswer- } \\
\text { derem }^{217} \\
\text { pod Ritterswer- } \\
\text { derem (?) } \\
\text { pod Marien- } \\
\text { werderem (?) }\end{array}$ & SRP III, s. 257-258 & \\
\hline VII & & $\begin{array}{l}\text { nad rzeką } \\
\text { Wilią }^{218}\end{array}$ & $\begin{array}{l}\text { SRP III, s. 258; APT, } \\
\text { Kat. I, nr } 421\end{array}$ & \\
\hline XII & & Litwa (?) & MTB, s. $215-216^{219}$ & \\
\hline
\end{tabular}

zob. V. Almonaitis, Žemaitijos politine padetis..., s. 132-137. J. Purc datuje pobyt Witolda w Kownie na okres wcześniejszy, opierając się na wiadomości oficjała pomezańskiego; SRP III, s. 241, z powołaniem się na pracę: M. Goyski, op. cit., s. 30. Jednak w tym miejscu kronikarz mówi jedynie o tym, że Witold rozkazał umocnić załogi Kowna i innych zamków litewskich; nie wiadomo zaś, czy osobiście brał udział w tej akcji.

${ }^{214}$ Data wydarzeń, o których oficjał pomezański pisze przed i po wiadomości o wyprawie Witolda na Nowogród. Właściwa chronologia wypraw Witolda na Nowogród, Smoleńsk i pod Kowno nie jest jasna.

${ }^{215}$ Na wzmiankę w rachunkach krakowskich o spotkaniu Witolda i jego żony Anny, zmierzających na ślub Jagiełły, zwrócił uwagę M. Starzyński, Litwa i Litwini w księgach rachunkowych średniowiecznego Krakowa (czasy Jagiełly $i$ Witolda), „Średniowiecze Polskie i Powszechne” 4, 2012, s. 225 -226. Wcześniej J. Voigt pisał o nieobecności Witolda na Litwie, wywodząc to z faktu wyprawy krzyżackiej na Grodno; idem, Geschichte Preußens, t. 6, Königsberg 1834, s. 216-217; SD I 743.

216 O datacji zob. ПГ II, s. 59-60 (kom. S.P.).

217 J. Purc odnosi wyprawę na Gotteswerder do maja 1402 r., powołując się na: A. Prochaska, op. cit., s. 103. Jednak źródło datuje napad Żmudzinów na Kłajpedę na 25 maja, natomiast Witold zaatakował Gotteswerder „niedługo potem”.

218 J. Purc datuje na lipiec 1402 r., powołując się na: ibidem, s. 103 (błędnie wskazana s. 82). Skoro wyprawa rozpoczęła się 25 lipca, to spotkanie z Witoldem mogło mieć miejsce nie wcześniej niż w sierpniu. Dalej J. Purc odnotowuje pobyt Witolda w Ragnecie w ostatnich dniach grudnia 1402 r., powołując się na: L. Kolankowski, Dzieje Wielkiego Księstwa Litewskiego za Jagiellonów, t. 1, Warszawa 1930, s. 82, ale podstawą jest wiadomość oficjała pomezańskiego o ataku Litwinów i Żmudzinów na Ragnetę (SRP III, s. 263); nie wiadomo, czy brał w nim udział Witold.

219 Wysłanie posła na Litwę przez wielkiego mistrza. 


\begin{tabular}{|c|c|c|c|c|}
\hline \multicolumn{2}{|c|}{ Data } & Miejsce & Źródło & Uwagi \\
\hline \multicolumn{5}{|c|}{1403} \\
\hline I & & Wilno & SRP III, s. 265 & \\
\hline \multirow[t]{2}{*}{ II } & 4 & Wilno (?) $)^{220}$ & ПГ I 45 & \\
\hline & ok. 6 & Wilno & Dług. X, s. 253 & \\
\hline \multicolumn{2}{|c|}{$\begin{array}{l}\text { między } 26 \text { II a } 24 \text { III } \\
\text { lub } 15 \text { IV; może po } \\
15 \text { IV (?) }\end{array}$} & Dyneburg & $\begin{array}{l}\text { SRP III, s. 266; ПЛ II, } \\
\text { s. } 110\end{array}$ & $\begin{array}{l}\text { wyprawa Witolda na } \\
\text { Dyneburg „тоя же зимы” }\end{array}$ \\
\hline III & 28 & Dubicze $(?)^{221}$ & ПГ І 43 & \\
\hline IV & & Jurbork $^{222}$ & SRP III, s. 266 & \\
\hline VI & 5 & Grodno & ПГ І 46 = LUB VI 2959 & \\
\hline VI & $19-20$ & Lublin $^{223}$ & $\begin{array}{l}\text { AUPL 45; KDMK I } 103 \\
=\text { Vitoldiana } 178\end{array}$ & \\
\hline IX & 8 & $\begin{array}{l}\text { wyspa na } \\
\text { Dubissie }\end{array}$ & $\begin{array}{l}\text { SRP III, s. } 267-268 \text {; } \\
\text { MTB, s. } 214,215\end{array}$ & $\begin{array}{l}\text { zjazd z wielkim mistrzem } \\
\text { krzyżackim, na który Jagiełło } \\
\text { nie przybył (Szweda 2009, } \\
\text { s. } 368 \text { ) } \\
\end{array}$ \\
\hline XI & 14 & $\begin{array}{l}\text { Grodno } \\
(\text { plan })^{224}\end{array}$ & CDP VI 159 & \\
\hline \multirow[t]{2}{*}{ XII } & $\begin{array}{l}\text { przed } \\
25^{225}\end{array}$ & $\begin{array}{l}\text { na łowach } \\
\text { w puszczy } \\
\text { u granic władz- } \\
\text { twa zakonu } \\
\end{array}$ & $\begin{array}{l}\text { GStAPK, OBA } 737= \\
\text { BGDO II } 5^{\star}=\text { CEV } 279^{*}\end{array}$ & \\
\hline & 25 & Wilno & $\begin{array}{l}\text { GStAPK, OBA } 737= \\
\text { BGDO II } 5^{*}=\text { CEV } \\
279^{*} \text {; SRP III, s. } 269\end{array}$ & $\begin{array}{l}\text { spotkanie z Jagiełłą i posłami } \\
\text { wielkiego mistrza krzyżac- } \\
\text { kiego (Gąsiorowski 2015, } \\
\text { s. 56) }\end{array}$ \\
\hline
\end{tabular}

220 O datacji zob. ПГ II, s. 61 (kom. S.P.).

221 O dacie zob. ПГ II, s. 59-60 (kom. S.P.).

222 J. Purc odnotowuje pobyt Witolda w Ragnecie pod koniec kwietnia 1403 r., jednak oficjał pomezański podaje, że wielki książę nie odważył się ruszyć tam z Jurborka, gdy dowiedział się o obecności tam wielkiego marszałka zakonu; SRP III, s. 266.

223 J. Purc odnotowuje pobyt Witolda na wyspie salińskiej 29 VI 1403 r., powołując się na Długosza, jednak zjazd polsko-litewsko-krzyżacki opisany przezeń pod datą 29 VI 1405 r. w rzeczywistości odbył się 8 IX 1403 r.; Dług. X, s. 263; Szweda 2009, s. 368.

224 J. Purc odnotowuje pobyt Witolda w Nowogródku 8 XI 1403 r., jednak list, na który się powołuje (IA 397 = Russisch-Livländische Urkunden, oprac. K.E. Napiersky, St. Petersburg 1868, nr 143), nie ma daty rocznej i może być przypuszczalnie datowany na koniec pierwszej dekady XV w.; ПГ І 29; ПГ II, s. 46-47 (kom. S.P.).

225 Zapewne w listopadzie albo grudniu Witold wysłał do wielkiego mistrza swego pisarza, na którego wydatki zostały odnotowane w księdze skarbnika malborskiego wśród wpisów za grudzień 1403 r.; MTB, s. 278. 


\begin{tabular}{|c|c|c|c|c|}
\hline \multicolumn{2}{|c|}{ Data } & Miejsce & Źródło & Uwagi \\
\hline \multicolumn{5}{|c|}{1404} \\
\hline I & przed 21 & Wilno & $\begin{array}{l}\text { GStAPK, OBA } 737= \\
\text { BGDO II } 5=\text { CEV } 279^{\star} \text {; } \\
\text { SRP III, s. } 269 ; \text { MTB, } \\
\text { s. } 286,314\end{array}$ & \\
\hline \multirow[t]{2}{*}{ II } & 3 & Wilno $(?)^{226}$ & ПГ I 45 & \\
\hline & 14 & Wilno & Vitoldiana 58 & \\
\hline \multicolumn{2}{|c|}{ III-V (?) } & $\begin{array}{l}\text { pod Smoleń- } \\
\text { skiem }\end{array}$ & ПСРЛ IV/1, s. $396^{227}$ & oblężenie Smoleńska \\
\hline \multicolumn{2}{|c|}{$\begin{array}{l}\text { koniec maja - } \\
\text { początek czerwca }\end{array}$} & Litwa (?) & CEV $293^{228}$ & \\
\hline VI & 26 & Smoleńsk & ПСРЛ IV/1, s. 397 & \\
\hline VIII & 17 & Kowno & $\begin{array}{l}\text { CEV 295, 297; VDO I } \\
\text { 32-34; SRP III, s. } 272\end{array}$ & $\begin{array}{l}\text { zjazd } \mathrm{z} \text { wielkim mistrzem } \\
\text { krzyżackim }\end{array}$ \\
\hline IX & 20 & $\begin{array}{l}\text { Kamieniec } \\
\left(^{(L i t e w s k i ?)^{229}}\right.\end{array}$ & AUPL 46 & $\begin{array}{l}\text { spotkanie z Jagiełłą } \\
\text { (Gąsiorowski 2015, s. 58) }\end{array}$ \\
\hline
\end{tabular}

226 O dacie zob. ПГ II, s. 61 (kom. S.P.).

227 Latopisy grupy nowogrodzko-sofijskiej informują o oblężeniu Smoleńska przez Witolda przez 7 tygodni, przerwanym po Wielkanocy (30 III). R. Biespałow przypuszcza, że w latopisie sofijskim I datacja jest zniekształcona, a Witold oblegał Smoleńsk przez 7 tygodni po Wielkanocy od 30 marca do 17 maja (Р.А. Беспалов, Литовско-московские отношения..., s. 144), przy czym opiera się na fakcie, że latopisarz datuje oblężenie na wiosnę, a Witolda nie było na pertraktacjach z zakonem krzyżackim w Raciążku (zob. następny przypis).

${ }^{228}$ List wielkiego mistrza do Witolda z 12 VI 1404 r., zawierający odpowiedź na list tegoż i propozycję spotkania na Wniebowzięcie NMP, czyli 15 sierpnia - odbyło się ono w Kownie. Jak widać z odpowiedzi, Witold proponował spotkanie latem 1404 r. i uprzedzał, że będzie poza Litwą właściwą, niejasne jednak, jak długo. Najprawdopodobniej list Witolda mógł zostać napisany na Litwie właściwej pod koniec maja lub na początku czerwca (temu nie przeczy fakt zajęcia Smoleńska przez wojsko pod dowództwem Witolda 26 czerwca), ale już po wysłaniu do Prus Moniwida, który był w Malborku 8 czerwca (CEV 291) i sądząc z odpowiedzi wielkiego mistrza, nie proponował konkretnego terminu spotkania. Wbrew opinii części badaczy, m.in. J. Purca, Witold nie był obecny w Raciążku podczas zawarcia pokoju z zakonem 22-23 V 1404 r., w jego imieniu działali jego dostojnicy i sam król Władysław Jagiełło; zob. A. Prochaska, $Z$ Witoldowych dziejów, „Przegląd Historyczny” 15, 1912, nr 3, s. 264-267; Szweda 2009, s. 369. Przy tym dokumenty Witolda wystawione w tym dniu są spisane przez jego pisarza; R. Čapaite, Gotikinis kursyvas..., s. 496.

${ }^{229}$ W itinerarium Jagiełły miejscowość ta została zidentyfikowana jako Kamieniec Podolski; Gąsiorowski 2015, s. 58. Jednak jeszcze 12 września król był w Sandomierzu, który od Kamieńca Podolskiego dzieli ponad 500 km, od Kamieńca Litewskiego zaś ok. 300 km. Ponadto ten ostatni znajdował się bliżej Litwy właściwej, gdzie zwykle przebywał Witold. Dlatego uważam za bardziej prawdopodobne, że chodziło o Kamieniec Litewski. Serdecznie dziękuję dr. hab. Witalijowi Michałowskiemu (Kijów), który zwrócił mi na to uwagę. 


\begin{tabular}{|c|c|c|c|c|}
\hline \multicolumn{2}{|c|}{ Data } & \multirow{2}{*}{\begin{tabular}{|l}
\multicolumn{1}{|c}{ Miejsce } \\
Wilno
\end{tabular}} & \multirow{2}{*}{\begin{tabular}{|l|}
\multicolumn{1}{|c}{ Źródło } \\
CEV 299, por. MTB, \\
s. 326
\end{tabular}} & \multirow[t]{2}{*}{ Uwagi } \\
\hline XII & & & & \\
\hline \multicolumn{5}{|c|}{1405} \\
\hline \multirow[t]{2}{*}{$\mathrm{I}$} & 1 & Gruti & ПГ І 47 & \\
\hline & & Żmudź & SRP III, s. 276-277 & $\begin{array}{l}\text { wspólna wyprawa litewsko- } \\
\text {-krzyżacka w celu podporząd- } \\
\text { kowania Żmudzi zakonowi } \\
\text { krzyżackiemu }\end{array}$ \\
\hline \multirow[t]{2}{*}{ II } & $\begin{array}{l}\text { początek } \\
(?)\end{array}$ & Litwa (?) & MTB, s. 345 & \\
\hline & 24 & Włodzimierz & $\begin{array}{l}\text { AGAD, terr. Droh. 2, } \\
\text { k. 379-379v = Jaszczołt } \\
\text { (przyg.), nr } 1\end{array}$ & \\
\hline III & 21 & $\begin{array}{l}\text { Jarosławska } \\
\text { łąka (an der } \\
\text { Jareslowen } \\
\text { wesen) }\end{array}$ & CEV $308^{231}$ & \\
\hline VI & 7 & Kowno 232 & $\begin{array}{l}\text { LUB IV } 1659=\text { CEV } \\
310^{*} \text { (plan); CEV } 316\end{array}$ & \\
\hline VIII & 2 & Żmudź $z^{233}$ & $\begin{array}{l}\text { CEV 321, 316; SRP III, } \\
\text { s. 277-278 }\end{array}$ & $\begin{array}{l}\text { wspólna wyprawa litewsko- } \\
\text {-krzyżacka w celu podporząd- } \\
\text { kowania Żmudzi zakonowi } \\
\text { krzyżackiemu }{ }^{234}\end{array}$ \\
\hline IX & & Wołyń (?) & MTB, s. $360,368^{235}$ & \\
\hline
\end{tabular}

${ }^{230}$ O udziale wojsk pruskich w wyprawie zob. GStAPK, OBA 833; Księga komturstwa gdańskiego, wyd. K. Ciesielska, I. Janosz-Biskupowa, Warszawa-Poznań-Toruń 1985, s. 237; Das Elbinger Kriegsbuch (1383-1409). Rechnungen für städtische Aufgebote, oprac. D. Heckmann, współpr. K. Kwiatkowski, Köln-Weimar-Wien 2013 (Veröffentlichungen aus den Archiven Preussischer Kulturbesitz, t. 68), s. 175-179. O wyprawie litewsko-krzyżackiej na Żmudź pod 1405 r. wspomina Długosz, ale nie wiadomo, którą z dwu wypraw miał na myśli (Dług. X, s. 264).

231 Zapewne list Witolda dostarczył wielkiemu mistrzowi herold wielkoksiążęcy, na którego wydatki zostały odnotowane w księdze skarbnika malborskiego pod koniec marca 1405 r.; MTB, s. 348.

232 Długosz pomyłkowo odniósł zjazd polsko-litewsko-krzyżacki, który odbył się 8 IX 1403 r. nad rzeką Dubissą, do 29 VI 1405 r.; Dług. X, s. 263; Szweda 2009, s. 368; por. Gąsiorowski 2015, s. 59; K. Kwiatkowski, A. Szweda, Nieco uwag o ksiązce Marka Radocha, ZH, 77, 2012, nr 3, s. 111.

233 Wojska krzyżackie wyruszyły w wyprawę w lipcu; SRP III, s. 277-278, Anm. 6. 22 VII 1405 r. wielki mistrz informował księcia mazowieckiego Janusza Starszego, że prawie wszyscy jego komturzy są na wyprawie; GStAPK, OF 3, s. 206-207.

234 Zob. też: Księga komturstwa gdańskiego..., s. 237-238; Das Elbinger Kriegsbuch..., s. 179-181.

${ }^{235}$ W drugim przypadku wskazano kierunek wysłania posłów - „ken Luczke”. 


\begin{tabular}{|c|c|c|c|c|}
\hline \multicolumn{2}{|c|}{ Data } & \multirow{2}{*}{$\begin{array}{r}\text { Miejsce } \\
\text { Miłolub (?) }\end{array}$} & \multirow{2}{*}{\begin{tabular}{|l|}
\multicolumn{1}{c}{ Źródło } \\
ТЛ, s. 459
\end{tabular}} & \multirow{2}{*}{$\begin{array}{c}\text { Uwagi } \\
\text { spotkanie Witolda i Jagiełły } \\
\text { z metropolitą Cyprianem }{ }^{236}\end{array}$} \\
\hline $\mathrm{X}$ & & & & \\
\hline XII & & Litwa (?) & MTB, s. 378 & \\
\hline \multicolumn{5}{|c|}{1406} \\
\hline \multirow[t]{2}{*}{ I } & 21 & $\begin{array}{l}\text { Wilno, wyru- } \\
\text { szenie na } \\
\text { wyprawę na } \\
\text { Ruś (plan) (?) }\end{array}$ & CEV $358^{237}$ & \\
\hline & 29 & Kołoże & $\begin{array}{l}\text { ПЛ І, s. } 28 ; \text { ПЛ IІ, } \\
\text { s. } 31-32,111-112 ; \text { НПЛ, } \\
\text { s. } 398 ; \text { ПСРЛ IV/1, } \\
\text { s. } 398-399\end{array}$ & wyprawa na Psków \\
\hline \multirow[t]{2}{*}{ II } & $\begin{array}{l}\text { między } 5 \\
\text { i } 10\end{array}$ & Woronacz & $\begin{array}{l}\text { ПЛ І, s. 28; ПЛ ІІ, } \\
\text { s. 31-32, 111-112; НПЛ, } \\
\text { s. 398-399; ПСРЛ IV/1, } \\
\text { s. 398-399; HUB V 364, } \\
365\end{array}$ & \\
\hline & 23 & Wilno & ПГ І 53 & \\
\hline V & 2 & Kowno & $\begin{array}{l}\text { MTB, s. } 378,387-389 \\
394\end{array}$ & $\begin{array}{l}\text { zjazd } \mathrm{z} \text { wielkim mistrzem } \\
\text { krzyżackim }\end{array}$ \\
\hline VI & 30 & Kopyś & ПГ І 54 & \\
\hline \multirow[t]{3}{*}{ VII } & 2 & Kopyś & ПГ І 54 & \\
\hline & 4 & Orsza & CEV $349^{238}$ & \\
\hline & przed 25 & $\begin{array}{l}\text { wyruszenie na } \\
\text { wyprawę na } \\
\text { Wielkie Księ- } \\
\text { stwo Moskiew- } \\
\text { skie }\end{array}$ & SRP III, s. 282-283 & $\begin{array}{l}\text { wyprawa na Wielkie Księstwo } \\
\text { Moskiewskie }\end{array}$ \\
\hline
\end{tabular}

${ }^{236} \mathrm{~W}$ latopisie troickim wydarzenie umieszczono między wiadomościami o wyjeździe Cypriana na Litwę i do Polski w 1405 r. Datowanie na podstawie informacji o pobycie Jagiełły w ruskich ziemiach Korony; Gąsiorowski 2015, s. 60. Zlokalizowanie Miłolubu nie udało się (szczegóły zob. indeks geograficzny). Uzupełniającą informacją o przebywaniu Jagiełły w Sandomierzu, prawdopodobnie $\mathrm{w}$ drugiej połowie sierpnia $1405 \mathrm{r}$., daje dokument wystawiony przez niego biskupstwu przemyskiemu (AGZ VII 26), którego data jest zniekształcona (w 1407 r., do którego odnosi się dokument, metropolita Cyprian już nie żył); zob. Б.Н. Флоря, Исследования по истории Церкви: древнерусское и славянское Средневековье, Москва 2007, s. 318; С. Келембет, Федір-Федот (Федюшко) Любартович, князь луцький $і$ володимирський, державия сіверський, „Сіверянський літопис” 2018, nr 6(144), s. 34-35, przyр. 100.

237 W liście Witolda brak daty rocznej. W CEV umieszczono go pod 21 I 1406 r.; R. Biespałow proponuje datę 21 I 1407 r.; P.А. Беспалов, Литовско-московские отношения..., s. 150, przyp. 112.

${ }^{238}$ W CEV pod datą 3 VII 1407 r.; poprawną datację zob. P.A. Беспалов, Литовско-московские отношения..., s. 153, przyp. 125. 


\begin{tabular}{|c|c|c|c|c|}
\hline \multicolumn{2}{|c|}{ Data } & Miejsce & Źródło & Uwagi \\
\hline \multirow[t]{3}{*}{ IX } & 2 & Briańsk & CEV 347 & \\
\hline & 3 & Briańsk & CEV 348 & \\
\hline & $22-30^{239}$ & $\begin{array}{l}\text { nad rzeką } \\
\text { Pławą }\end{array}$ & ПСРЛ ХV, s. 474-475 & \\
\hline XII & & Wilno & NKRSME 352 & \\
\hline \multicolumn{5}{|c|}{1407} \\
\hline \multirow[t]{4}{*}{ I } & 8 & Wilno (plan) & CEV $356^{240}$ & \\
\hline & 13 & Wilno & $\begin{array}{l}\text { Vitoldiana } 70 \text {; GStAPK, } \\
\text { OBA } 1046^{241}\end{array}$ & \\
\hline & 16 & Wilno & $\begin{array}{l}\text { AGAD, Zb. dok. perg. } \\
242=\text { Scriptores rerum } \\
\text { Silesiacarum, t. 1, Lipsiae } \\
1729, \text { s. } 951\end{array}$ & \\
\hline & $21(?)$ & $\begin{array}{l}\text { Wilno, } \\
\text { wyruszenie } \\
\text { w wyprawę na } \\
\text { Ruś (plan) } \\
\end{array}$ & CEV $358^{242}$ & \\
\hline $\mathrm{V}$ & $26-28^{243}$ & Litwa & $\begin{array}{l}\text { GStAPK, OBA } 928= \\
\text { CEV } 367^{\star} \text {; por. MTB, } \\
\text { s. } 433\end{array}$ & \\
\hline VI & 11 & Wilno 244 & KDKW 45 & \\
\hline VII & & Litwa (?) & MTB, s. 442 & \\
\hline VIII-IX & & pod Wiaźmąą ${ }^{245}$ & $\begin{array}{l}\text { ПСРЛ ХХV, s. 237; } \\
\text { ПСРЛ ХV, s. } 478\end{array}$ & \\
\hline
\end{tabular}

239 Por. obliczenia chronologii wyprawy moskiewskiej Witolda: Р.А. Беспалов, Литовско-московские отночения..., s. 158-159.

${ }^{240}$ W liście z 21 XII 1406 r. wielki mistrz prosił już Witolda, aby poczekał na mieszczan toruńskich po ustalonym terminie ze względu na niewygodną drogę (CEV 357).

${ }^{241}$ List dostojnika krzyżackiego do wielkiego marszałka o podróży do Witolda ma tylko datę dzienną - 21 stycznia (św. Agnieszka), rok wynika ze wzmianki o arbitrażu Witolda w sporze między kupcami toruńskimi a krakowskimi (por. CEV 356, 357). O pobycie Witolda na Litwie zob. też MTB, s. 417.

${ }^{242}$ Możliwa także datacja na 21 I 1406 r.; zob. przyp. 237.

243 J. Purc odnotowuje pobyt Witolda w Wilnie $20 \mathrm{~V} 1407$ r., powołując się na АЛРГ 2, jednak opublikowany tam przywilej Witolda dla Ilii Wiaczkowicza jest falsyfikatem, na co wskazuje jego pismo; AGAD, Zb. dok. perg. nr 8488 = Vitoldiana 218; W. Kuraszkiewicz, Gramoty halicko-wołyńskie XIV-XV wieku. Studium językowe, Kraków 1934, s. 132.

${ }^{244}$ List, na który powołuje się J. Purc na potwierdzenie pobytu Witolda w Orszy 3 VII 1407 r. (CEV 349), w rzeczywistości pochodzi z 4 VII 1406 r. (zob. wyżej).

245 A.L.Choroszkiewiczopublikowała według odpisu dziewiętnastowiecznego układ Wasyla Iz Witoldem z datą „А писанъ на Вязмъ сентя[бря] 4 день”. Na podstawie itinerarium Witolda umieściła go w 1407 r.; А.Л. Хорошкевич, Документы начала XV в. о русско-литовских 


\begin{tabular}{|c|c|c|c|c|}
\hline \multicolumn{2}{|c|}{ Data } & \multirow{2}{*}{\begin{tabular}{l}
\multicolumn{1}{c}{ Miejsce } \\
nad rzeką \\
Klimkówką
\end{tabular}} & \multirow{2}{*}{\begin{tabular}{|l|}
\multicolumn{1}{|c}{ Źródło } \\
CEV 371; por. MTB, \\
s. 461
\end{tabular}} & \multirow[t]{2}{*}{ Uwagi } \\
\hline XII & 13 & & & \\
\hline \multicolumn{5}{|c|}{1408} \\
\hline \multirow[t]{2}{*}{ I } & $6-8$ & Kowno ${ }^{246}$ & $\begin{array}{l}\text { CEV } 371 \text { (plan); } \\
\text { Dług. X-XI, s. 18-19; } \\
\text { SRP III, s. } 289\end{array}$ & $\begin{array}{l}\text { zjazd z Jagiełłą, wielkim } \\
\text { mistrzem krzyżackim } \\
\text { i mistrzem inflanckim } \\
(\text { Szweda } 2009, \text { s. } 373-374)^{247}\end{array}$ \\
\hline & 25 & Wilno & Vitoldiana 182 & \\
\hline II & 14 & Birsztany (?) & Vitoldiana $213^{248}$ & \\
\hline V & & Litwa (?) & MTB, s. 483 & \\
\hline \multirow[t]{2}{*}{ VI } & 21 & Troki & CEV 378 = LUB IV 1758 & \\
\hline & 25 & $\begin{array}{l}\text { Wilno (wyru- } \\
\text { szenie na } \\
\text { wyprawę na } \\
\text { Wielkie Księ- } \\
\text { stwo Moskiew- } \\
\text { skie) }\end{array}$ & Dług. X-XI, s. 19 & $\begin{array}{l}\text { wyprawa na Wielkie Księstwo } \\
\text { Moskiewskie }\end{array}$ \\
\hline IX & $1-15$ & nad rzeką Ugrą & $\begin{array}{l}\text { ПСРЛ ХХV, s. 237-238; } \\
\text { ЕFЕ II } 67\end{array}$ & \\
\hline
\end{tabular}

отношениях, w: Культурные связи России и Польши XI-XX вв., Москва 1998, s. 39-57, s. 40-47, 51-52. Теј datacji nie wykluczają też inni badacze; Д.И. Иванов, op. cit., s. 106-107; P.А. Беспалов, Литовско-московские отношения..., s. 163-163. Jednak źródła współczesne dowodnie mówią o zawarciu jesienią 1407 r. nie pokoju, lecz tylko rozejmu między Wasylem I a Witoldem (np. CEV 374), a wiele wskazuje na podobieństwo tego układu z układem Witolda z wielkim księciem twerskim Borysem Aleksandrowiczem z 1427 r., który zachował się w oryginale i ma datę: „А п(и)сано во Тфъри, в ль $m$ (о) 6000-ное девАть[сотное 3] 5, авгус(та) 3 д(е)нь, индикта 5", ДДГ 23. Ale nawet gdybyśmy uznali, że układ opublikowany przez A.L. Choroszkiewicz jest autentyczny - przeciwko czemu jednak, moim zdaniem, przemawia jego stylizacja - to 3 VIII $1427 \mathrm{r}$. Witolda nie było w Twerze.

246 Annalista toruński pisze o zjeździe braci zakonnych z Witoldem i Jagiełłą w Trokach 8 stycznia; SRP III, s. 289. Zapewne Witold nie brał udziału w następnej wyprawie mistrza inflanckiego na Psków, a tylko wysłał tam wojska; ibidem.

${ }^{247}$ O planowanym udziale wielkiego księcia moskiewskiego Wasyla I w tym zjeździe zob. Hildebrand Veckinchusen. Briefwechsel eines deutschen Kaufmanns im 15. Jahrhundert, wyd. W. Stieda, Leipzig 1921, nr 15, s. 18.

248 Przywilej Witolda dla niemieckich mieszczan Kowna jest siedemnastowiecznym falsyfikatem. Jego podstawą był przywilej, rzeczywiście wydany przez Witolda mieszczanom kowieńskim, a ściślej: jego wersja skrócona. Data zapewne została przejęta z oryginalnego przywileju; zob. Z. Kiaupa, 1408 metų Vytauto privilegija Kauno miestui, LIM, 1979 [1981], s. 5-19 (tamże literatura przedmiotu).

249 J. Purc dalej odnotowuje pobyt Witolda w Smoleńsku, powołując się na Dzieje narodu litewskiego Teodora Narbutta, co jednak nie znajduje bezpośrednich potwierdzeń we wczesnych źródłach. 


\begin{tabular}{|c|c|c|c|c|}
\hline \multicolumn{2}{|c|}{ Data } & \multirow{2}{*}{\begin{tabular}{|l}
\multicolumn{1}{|c}{ Miejsce } \\
Wilno \\
\end{tabular}} & \multirow{2}{*}{$\begin{array}{r}\text { Źródło } \\
\text { EFE II } 67^{250}\end{array}$} & \multirow[t]{2}{*}{ Uwagi } \\
\hline & koniec (?) & & & \\
\hline XII & 25 & Nowogródek & $\begin{array}{l}\text { GStAPK, OBA } 1025= \\
\text { CEV } 388^{\star}\end{array}$ & $\begin{array}{l}\text { spotkanie z Jagiełłą poświad- } \\
\text { czonym na Litwie w grudniu } \\
1408 \text { - początkach stycznia } \\
1409 \text { r. (Gąsiorowski } 2015 \text {, } \\
\text { s. } 65 \text { ) }\end{array}$ \\
\hline \multicolumn{5}{|c|}{1409} \\
\hline \multirow[t]{2}{*}{ I } & 8 & $\begin{array}{l}\text { Wilno albo } \\
\text { Troki (plan) }\end{array}$ & $\begin{array}{l}\text { GStAPK, OBA } 1025= \\
\text { CEV } 388^{*}\end{array}$ & \\
\hline & 24 & Kiernów & CEV 391 & \\
\hline III & 20 & Berszty (?) $)^{251}$ & $\begin{array}{l}\text { Мікульскі 2014, nr 1, } \\
\text { s. } 128 \text { = Мицик 2018, } \\
\text { s. } 8\end{array}$ & \\
\hline \multirow[t]{3}{*}{ IV } & 6 & Troki (?) & Полехов 2018, nr $1^{252}$ & \\
\hline & 9 & Grodno & CEV 393 & \\
\hline & Po 9 & $\begin{array}{l}\text { nad rzeką } \\
\text { Wilią (Wilno?) }\end{array}$ & $\begin{array}{l}\text { CEV 396; por. MTB, } \\
\text { s. } 540,543\end{array}$ & \\
\hline \multirow[t]{5}{*}{ V } & 6 & Żyżmory & CEV 396 & \\
\hline & 23 & Troki & Vitoldiana 72 & \\
\hline & 24 & Nowe Troki & KDKW 50 & \\
\hline & 26 & Kowno & CEV 398 & \\
\hline & 27 & Troki & CEV 399 & \\
\hline VI & 6 & Kowno $^{253}$ & CEV 405 & \\
\hline VII & przed 12 & Kowno & $\begin{array}{l}\text { GStAPK, OBA } 1031= \\
\text { CEV } 418^{*}\end{array}$ & \\
\hline VIII & $5-7$ & Kowno & $\begin{array}{l}\text { CEV 421; Jóźwiak 2004, } \\
\text { s. 176-177254 }\end{array}$ & \\
\hline
\end{tabular}

${ }^{250}$ J. Purc odnotowuje pobyt Witolda „W obozie za Pińskiem” 6 XI 1408 r., powołując się na CEV 385, ale pospieszny wyjazd Witolda do Łucka, o którym jest tam mowa, tuż po jego powrocie z wyprawy moskiewskiej jest bardzo mało prawdopodobny. Jest więcej podstaw, by odnosić ten list do 1412 albo 1415 r., gdy Witold rzeczywiście jeździł do Łucka (zob. niżej, przyp. 276).

251 Możliwa także datacja dokumentu na $1424 \mathrm{r}$.

${ }^{252}$ Możliwa też datacja dokumentu na 6 IV 1398 albo (mniej prawdopodobne) 1420 r. - zob. wskazany artykuł.

253 O pobycie Witolda w Kownie, nie wskazując dokładnej daty, donosił także sługa wielkiego marszałka zakonu, który powrócił ze Żmudzi do Prus w połowie czerwca (CEV 410). L. Kolankowski, a za nim J. Purc, odnosili wojenne przygotowania Witolda w Kownie do wiosny 1409 r.

${ }^{254}$ Przywołany tu list komtura Ragnety do wielkiego marszałka zakonu (GStAPK, OBA 1110) obecnie jest nie do odnalezienia w GStAPK, wykorzystano mikrofilm z Archiwum Państwowego $\mathrm{w}$ Toruniu. 


\begin{tabular}{|c|c|c|c|c|}
\hline \multicolumn{2}{|c|}{ Data } & \multirow{2}{*}{$\begin{array}{r}\text { Miejsce } \\
\text { Kowno }\end{array}$} & \multirow{2}{*}{\begin{tabular}{|l}
\multicolumn{1}{|c}{ Źródło } \\
CEV 422 \\
\end{tabular}} & \multirow[t]{2}{*}{ Uwagi } \\
\hline & 12 & & & \\
\hline & 26 & Friedeburg & CEV 424 & \\
\hline \multirow[t]{3}{*}{ IX } & przed 15 & $\begin{array}{l}\text { wyprawa na } \\
\text { Mazowsze }\end{array}$ & $\begin{array}{l}\text { CEV 428; por. GStAPK, } \\
\text { OBA } 1155 \text {; WPL, s. } 138 \text {, } \\
\text { przyp. } 97\end{array}$ & \\
\hline & 20 & $\begin{array}{l}\text { przeprawa } \\
\text { przez Narew }\end{array}$ & $\begin{array}{l}\text { GStAPK, OBA 1148, } \\
1149\end{array}$ & \\
\hline & 30 & $\begin{array}{l}\text { podczas żeglugi } \\
\text { w górę i w dół } \\
\text { po rzece Narwi }\end{array}$ & GStAPK, OBA 1158 & \\
\hline $\mathrm{X}$ & 1 & Troki & ПГ І 59 & \\
\hline \multirow[t]{2}{*}{ XI } & 26 & Nowogródek & $\begin{array}{l}\text { GStAPK, OBA } 1172= \\
\text { CEV } 433^{*}\end{array}$ & \\
\hline & 30 & Brześć & Dług. X-XI, s. 43-44 & \\
\hline \multirow[t]{2}{*}{ XII } & & $\begin{array}{l}\text { Kamieniec } \\
\text { Litewski }\end{array}$ & Dług. X-XI, s. 44 & \\
\hline & & Litwa $^{255}$ & Dług. X-XI, s. 44 & \\
\hline \multicolumn{5}{|c|}{1410} \\
\hline II & 16 & Wilno & KDKW 51 & \\
\hline \multirow[t]{2}{*}{ III } & 16 & Słonim & \multirow{2}{*}{$\begin{array}{l}\text { Dług. X-XI, s. 39; } \\
\text { SRP III, s. } 313\end{array}$} & \\
\hline & po 16 & Zdzitów $^{256}$ & & \\
\hline \multirow[t]{10}{*}{ IV } & 1 & Łańcut & \multirow[t]{6}{*}{ Dług. X-XI, s. 54} & \\
\hline & \multirow{5}{*}{$\begin{array}{l}\text { między } 1 \\
\text { a } 6\end{array}$} & Rzeszów & & \\
\hline & & Ropczyce & & \\
\hline & & Pilzno & & \\
\hline & & Biecz & & \\
\hline & & Grebów & & \\
\hline & 6 & Nowy Sącz & Dług. X-XI, s. 54 & \\
\hline & & Kieżmark & Dług. X-XI, s. 54 & \\
\hline & $\begin{array}{l}10 \\
(\text { wyjazd }) \\
(?)\end{array}$ & Nowy Sącz & Dług. X-XI, s. 55 & \\
\hline & $12(?)$ & Lublin & Dług. X-XI, s. 55-56 & \\
\hline
\end{tabular}

255 J. Purc wskazuje Puszczę Białowieską jako miejsce pobytu Witolda pomimo bezpośredniego świadectwa Długosza o wyjeździe tam Jagiełły, Witolda zaś na Litwę.

${ }^{256}$ K. Kwiatkowski przypuszcza, że ze Zdzitowa Witold udał się na wschód Średniego Pobuża albo na północny Wołyń - może do Łucka; idem, Zygmunt Luksemburski wobec konfliktu..., s. 48-49. 


\begin{tabular}{|c|c|c|c|c|}
\hline \multicolumn{2}{|c|}{ Data } & \multirow{2}{*}{\begin{tabular}{|l} 
Miejsce \\
Brześć
\end{tabular}} & \multirow{2}{*}{\begin{tabular}{|l|}
\multicolumn{1}{|c|}{ Źródło } \\
Dług. X-XI, s. 56; \\
GStAPK, OBA 1265 \\
= Biskup 1959, nr 5, \\
s. 695-697
\end{tabular}} & \multirow[t]{2}{*}{ Uwagi } \\
\hline & $13-15$ & & & \\
\hline \multirow[t]{2}{*}{ V } & 13 & $\begin{array}{l}\text { u granicy } \\
\text { władztwa } \\
\text { zakonnego (na } \\
\text { lewym brzegu } \\
\text { Niemna na } \\
\text { zachód od } \\
\text { Grodna?) }\end{array}$ & CEV 439 & \\
\hline & 26 & Troki & $\begin{array}{l}\text { CEV 441; GStAPK, OBA } \\
1288=\text { CEV } 443^{\star}\end{array}$ & \\
\hline \multirow[t]{12}{*}{ VI } & 6 & Wilno & $\begin{array}{l}\text { Quirini-Popławska 2002, } \\
\text { s. } 219-220\end{array}$ & \multirow{13}{*}{$\begin{array}{l}\text { wojna Polski i Litwy } \\
\text { z zakonem krzyżackim }\end{array}$} \\
\hline & $10-11$ & $\begin{array}{l}\text { przeprawa } \\
\text { przez Niemen } \\
\text { (pod Grod- } \\
\text { nem?) }\end{array}$ & WPL, s. 253 & \\
\hline & do 14 & nad Narwią & $\begin{array}{l}\text { GStAPK, OBA } 1307, \\
1309,1317\end{array}$ & \\
\hline & $17(?)$ & $\begin{array}{l}\text { wyruszenie } \\
\text { znad Niemna }\end{array}$ & WPL, s. 255 & \\
\hline & 20 & Rudnik & \multirow{6}{*}{$\begin{array}{l}\text { GStAPK, OBA } 1317 \\
\text { (plan) }\end{array}$} & \\
\hline & 21 & Bielsk Podlaski & & \\
\hline & 22 & $\begin{array}{l}\text { nad rzeką Nur- } \\
\text { cem }\end{array}$ & & \\
\hline & 23 & Drohiczyn & & \\
\hline & 24 & Liw & & \\
\hline & $\begin{array}{l}25-26 \\
\text { lub } 30 \\
\text { (Dług.) }\end{array}$ & $\begin{array}{l}\text { Warszawa, } \\
\text { przeprawa } \\
\text { przez Wisłę }\end{array}$ & & \\
\hline & 29 & $\begin{array}{l}\text { pod Nowym } \\
\text { Dworem } \\
\text { Mazowieckim }\end{array}$ & Dług. X-XI, s. 64 & \\
\hline & 30 & $\begin{array}{l}\text { pod Czerwiń- } \\
\text { skiem }\end{array}$ & $\begin{array}{l}\text { CC, s. 15; Dług. X-XI, } \\
\text { s. } 65\end{array}$ & \\
\hline VII & 3 & $\begin{array}{l}\text { wyruszenie } \\
\text { spod } \\
\text { Czerwińska }\end{array}$ & Dług. X-XI, s. 67 & \\
\hline
\end{tabular}

257 O możliwej lokalizacji zob. WPL, s. 217, przyp. 166; s. 246, przyp. 33. 


\begin{tabular}{|c|c|c|c|c|}
\hline \multicolumn{2}{|c|}{ Data } & \multirow{2}{*}{$\begin{array}{l}\frac{1}{\text { Miejsce }} \\
\text { wieś w ziemi } \\
\text { płockiej }^{258}\end{array}$} & \multirow{2}{*}{\begin{tabular}{|l|}
\multicolumn{1}{c|}{ Źródło } \\
$\begin{array}{l}\text { CC, s. 16; Dług. X-XI, } \\
\text { s. } 68\end{array}$
\end{tabular}} & Uwagi \\
\hline & 4 & & & \\
\hline & $5-6$ & Jeżewo & Dług. X-XI, s. 68 & \\
\hline & $6-7$ & Bieżuń & $\begin{array}{l}\text { CC, s. 17; Dług. X-XI, } \\
\text { s. } 69\end{array}$ & \\
\hline & $7-9$ & Bądzyń & Dług. X-XI, s. 81 & \\
\hline & $9-10$ & $\begin{array}{l}\text { pod Zieluniem } \\
(?) \\
\text { pod } \\
\text { Lidzbarkiem, } \\
\text { Kowaliki }\end{array}$ & $\begin{array}{l}\text { CC, s. 18; Dług. X-XI, } \\
\text { s. } 71\end{array}$ & \\
\hline & $10-11$ & $\begin{array}{l}\text { nad jez. Rub- } \\
\text { kowo }\end{array}$ & Dług. X-XI, s. 73 & \\
\hline & $11-13$ & Wysoka & $\begin{array}{l}\text { CC, s. 19; Dług. X-XI, } \\
\text { s. } 78\end{array}$ & \\
\hline & $13-15$ & $\begin{array}{l}\text { za } 1 / 2 \text { mili od } \\
\text { Dąbrówna }\end{array}$ & $\begin{array}{l}\text { CC, s. 19; Dług. X-XI, } \\
\text { s. } 83\end{array}$ & \\
\hline & $15-17$ & $\begin{array}{l}\text { pod } \\
\text { Grunwaldem }\end{array}$ & $\begin{array}{l}\text { CC, s. } 19 \text { n.; Dług. X-XI, } \\
\text { s. } 83 \text { n. }\end{array}$ & \\
\hline & $17-18$ & $\begin{array}{l}\text { pod } \\
\text { Olsztynkiem }{ }^{259}\end{array}$ & Dług. X-XI, s. 126 & \\
\hline & 24 & Pasłęk & $\begin{array}{l}\text { ASP I 96; NKRSME } \\
1014\end{array}$ & \\
\hline & 25 & $\begin{array}{l}\text { pod } \\
\text { Malborkiem }\end{array}$ & Dług. X-XI, s. 130 & \\
\hline IX & ok. 4 & $\begin{array}{l}\text { wyruszenie } \\
\text { spod Malborka } \\
\text { na wschód } \\
\text { - nad rzeką } \\
\text { Pasłęką }\end{array}$ & $\begin{array}{l}\text { SRP III, s. 321; Dług. X- } \\
\text {-XI, s. 139; NKRSME } \\
1016\end{array}$ & \\
\hline & 8 & Bardyny & $\begin{array}{l}\text { Arbusow } 1911, \text { nr } 6, \\
\text { s. } 272-273=\text { Kujot } 1910 \text {, } \\
\text { nr 3, s. } 341-342\end{array}$ & $\begin{array}{l}\text { spotkanie z dostojnikami } \\
\text { krzyżackimi, zawarcie } \\
\text { rozejmu (WPL, s. 543) }\end{array}$ \\
\hline & $10-11$ & $\begin{array}{l}\text { pod } \\
\text { Malborkiem }\end{array}$ & $\begin{array}{l}\text { Dług. X-XI, s. } 140-141 \text {; } \\
\text { SRP III, s. } 322,398\end{array}$ & \\
\hline & po 11 & Mazowsze & SRP III, s. 321 & \\
\hline
\end{tabular}

258 O lokalizacji zob. WPL, s. 338.

259 O dalszym ciągnieniu wojska litewskiego, już oddzielnie od koronnego, zob. WPL, s. 480, przyp. 1234. 


\begin{tabular}{|c|c|c|c|c|}
\hline \multicolumn{2}{|c|}{ Data } & Miejsce & Źródło & Uwagi \\
\hline \multirow[t]{2}{*}{$\mathrm{X}$} & do 21 & Troki & \multirow{2}{*}{$\begin{array}{l}\text { GStAPK, OBA } 1376= \\
\text { Kujot } 1910, \text { nr } 4 \text {, s. } 342- \\
-343=\text { CEV } 456^{*}\end{array}$} & \\
\hline & 21 & Grodno & & \\
\hline XI & 16 & Nowogródek ${ }^{260}$ & AS I 104 & \\
\hline \multicolumn{5}{|c|}{1411} \\
\hline \multirow[t]{4}{*}{ I } & 11 & Płock (plan) & GStAPK, OBA 1421 & \\
\hline & 18 & $\begin{array}{l}\text { Brześć Kujaw- } \\
\text { ski }^{261}\end{array}$ & CEV 464 & \\
\hline & $22-24$ & $\begin{array}{l}\text { wyspa na Wiśle } \\
\text { koło Torunia }\end{array}$ & KDL, s. 125-127 & \multirow{3}{*}{$\begin{array}{l}\text { miejsca pobytu Witolda } \\
\text { i Jagiełły podczas pertraktacji } \\
\text { z Krzyżakami są częściowo } \\
\text { zbieżne (Gąsiorowski 2015, } \\
\text { s. 74; WPL, s. 703-712) }\end{array}$} \\
\hline & 26 & Włocławek & Dług. X-XI, s. 175 & \\
\hline \multirow[t]{2}{*}{ II } & 1 & Toruń & CESXV II 19 & \\
\hline & $\begin{array}{l}\text { między } \\
1 \text { a } 28\end{array}$ & Litwa $^{262}$ & $\begin{array}{l}\text { CEV } 471^{*}=\text { Pelech 1986, } \\
\text { nr } 11\end{array}$ & \\
\hline \multirow[t]{3}{*}{ III } & 5 & Dubicze & Vitoldiana $86^{263}$ & \\
\hline & przed 31 & Grodno & CEV 473 & \\
\hline & 31 & Grodno & $\begin{array}{l}\text { GStAPK, OBA } 1676= \\
\text { CEV } 540^{* 264}\end{array}$ & \\
\hline
\end{tabular}

${ }^{260}$ Według tego, co 17 XII 1410 r. donosił wielkiemu mistrzowi komtur Ostródy, Witold umawiał się na spotkanie w Ciechanowie z księciem mazowieckim Januszem Starszym, jednak plan ten nie doszedł do skutku; GStAPK, OBA 1421.

${ }^{261}$ Witold informuje wielkiego mistrza, że jest u króla. Pobyt tego ostatniego w Brześciu Kujawskim poświadczony jest 16-17 stycznia; Gąsiorowski 2015, s. 74.

${ }^{262}$ W niezachowanym sprawozdaniu z pertraktacji Michała Küchmeistra z Witoldem ich miejsce zapewne nie było wskazane. A. Prochaska w CEV przypuszczał, że odbyły się w Kownie, na co powołuje się też J. Purc. Jednak na potwierdzenie tej tezy A. Prochaska przywołał list wielkiego mistrza krzyżackiego do mistrza inflanckiego z lutego 1413 r. (LUB IV 1932), w którym jest mowa o przesłaniu sprawozdania z petraktacji odbytych krótko przed tym - pod koniec stycznia 1413 r. (sprawozdanie: CEV 529; o pertraktacjach zob. niżej). Dalej J. Purc odnotowuje pobyt Witolda w Wielonie 28 lutego, powołując się na SD II 954. Jednak w streszczonym tam źródle z niezachowanego OF 5 jest mowa o tym, że Witolda zamierza zbudować tam zamek.

${ }^{263}$ Możliwa data dokumentu - 14 II 1396 lub 5 III 1411 r., mniej prawdopodobna - 21 II 1426 (zob. wyżej, przyp. 197).

264 W CEV list Witolda do wielkiego mistrza o wymianie jeńców, napisany „czu Garthen am dinstage noch Judica", jest datowany na 11 IV $1413 \mathrm{r}$. Jednak Witold informuje w nim, że wyjeżdża na spotkanie króla polskiego, co odpowiada itinerarium Jagiełły wiosną 1411 r.; Gąsiorowski 2015, s. 74. Wtedy do Witolda przybył wspomniany w tym liście poseł krzyżacki Klotz; CEV 473, 476, 478. List jest spisany przez pisarza określanego jako „ręka nr 6” kancelarii Witolda, znane są sporządzone przez niego dokumenty i listy z lat 1407-1421; R. Čapaité, Gotikinis kursyvas..., s. $335-345,499, \mathrm{nr} 51$ - tu przypuszczalnie pod $1412 \mathrm{r}$. 


\begin{tabular}{|c|c|c|c|c|}
\hline \multicolumn{2}{|c|}{ Data } & Miejsce & Źródło & Uwagi \\
\hline \multirow[t]{3}{*}{ IV } & 12 & Wilno & CEV 474 & \\
\hline & 17 & Troki & CEV 475 & \\
\hline & 20 & Troki $^{265}$ & CEV 476 & \\
\hline \multirow[t]{3}{*}{$\mathrm{V}$} & 17 & Kowno & $\begin{array}{l}\text { LMAVB RS, F 15-73, } \\
\text { s. } 5 \text { = Kwiatkowski } 2016 \text {, } \\
\text { s. } 350\end{array}$ & \\
\hline & 19 & Kowno & $\begin{array}{l}\text { CEV } 478 \text {; por. GStAPK, } \\
\text { OBA } 1690^{266}\end{array}$ & \\
\hline & $\begin{array}{l}31 \text { i póź- } \\
\text { niej }\end{array}$ & Wilno & $\begin{array}{l}\text { LUB IV } 1888= \\
\text { CEV } 482^{*}\end{array}$ & \\
\hline \multicolumn{2}{|c|}{ V-VI } & Wielona & $\begin{array}{l}\text { GStAPK, OBA } 1772= \\
\text { CEV } 494^{\star 267}\end{array}$ & \\
\hline VI & $7-8$ & Wilno & CESXV II 37 & \\
\hline \multirow{2}{*}{\multicolumn{2}{|c|}{$\begin{array}{l}\text { między } 8 \text { VI } \\
\text { a } 11 \text { VII }\end{array}$}} & Zasław (?) $)^{268}$ & Dług. X-XI, s. 184 & \\
\hline & & $\begin{array}{l}\text { Połock (wyjazd } \\
\text { przed } 11 \text { VII) }\end{array}$ & $\begin{array}{l}\text { GStAPK, OBA } 1538 \\
\text { = LUB IV } 1888= \\
\text { CEV 482*; Dług. X-XI, } \\
\text { s. 184; por. LUB IV } 1899\end{array}$ & \\
\hline
\end{tabular}

265 Według Długosza 10 V 1411 r. Witold i Jagiełło w Złotorii spotkali się z władzami zakonnymi, a potem wrócili do swoich siedzib; Dług. X-XI, s. 179-181. To spotkanie niewątpliwie zostało wymyślone przez Długosza na podstawie znanego mu dokumentu $\mathrm{z}$ archiwum koronnego $\mathrm{z}$ tą datą. W rzeczywistości w Złotorii odbyło się jedynie spotkanie doradców władców (Szweda 2009, s. 378; WPL, s. 739), podczas gdy Witold i Jagiełło przebywali na Litwie i Rusi (por. Gąsiorowski 2015, s. 74). 18 XI 1411 r. Jagiełło wyjaśniał, że nie przekazał pewnych dokumentów zakonowi ze względu na pobyt daleko na Rusi („wir von dessem reiche czu den allervordersten unsern landen czu Rüwssen sein gewest, so daz wir der brife, die wir euch zulden gegeben haben obir daz landt czu Samaythen und der freigebunge der andern gefangenen, nicht gewarten mochten", GStAPK, OBA 1586). 18 II 1412 r. prokurator zakonu przy kurii rzymskiej z niezadowoleniem pisał do wielkiego mistrza, że Jagiełło stale bawi się na Litwie i Rusi, dawno nie pojawiał się w Krakowie i dlatego nie może spotkać się z przedstawicielami zakonu; BGDO II 68. O kontekście politycznym zob. A. Szweda, Po wielkiej wojnie. Zjazdy polsko-krzyżackie w 1411 roku, w: Kancelaria wielkich mistrzów i polska kancelaria królewska..., s. 267-298.

${ }^{266}$ List wielkiego marszałka do wielkiego mistrza o mającej się odbyć podróży z Ragnety do Witolda datowany jest na sobotę po św. Marku, bez daty rocznej. Na podstawie wzmianki o pośle krzyżackim Klotzu (por. wyżej, przyp. 264) datuję ten list na $2 \mathrm{~V} 1411 \mathrm{r}$.

267 W doniesieniu wielkiego mistrza o poselstwie komtura Ragnety do Witolda i Jagiełły jest mowa o tym, że „der koning von Polan czu jore im somer selben uff den walen czu Welune mit herczog Wytowt ist gewest”. Najprawdopodobniej ta podróż odbyła się nie latem, gdy Witold z Jagiełłą objeżdżali ziemie ruskie Wielkiego Księstwa Litewskiego, lecz późną wiosną - w maju, zapewne po drodze do Kowna.

${ }^{268}$ Długosz pisze o podróży Jagiełły i Witolda trasą Wilno - Połock - Witebsk - Smoleńsk - Krzyczów - Zasław, skąd mieli oni zapewne popłynąć Dnieprem do Kijowa. Z tego schematu wypada Zasław, położony daleko od Dniepru, podczas gdy podróż z Krzyczowa nad Dniepr wydaje się 


\begin{tabular}{|c|c|c|c|c|}
\hline \multicolumn{2}{|c|}{ Data } & Miejsce & Źródło & Uwagi \\
\hline \multirow{3}{*}{\multicolumn{2}{|c|}{$\begin{array}{l}\text { między } 11 \text { VII } \\
\text { a } 17 \text { VIII }\end{array}$}} & Witebsk & \multirow{3}{*}{ Dług. X-XI, s. 184} & \\
\hline & & \multirow{2}{*}{\begin{tabular}{|l|} 
Smoleńsk \\
Krzyczów
\end{tabular}} & & \\
\hline & & & & \\
\hline VIII & $17^{269}$ & Kijów & $\begin{array}{l}\text { LMAVB RS, F } 15-73 \text {, } \\
\text { s. } 300^{270} \text { (plan); } \\
\text { CEV 483; GStAPK, OBA } \\
1707,1768=\text { CEV } 495^{*} \text {, } \\
498 \text { (s. } 245 \text {, przyp.); } \\
\text { Журнал TУАК, s. } 48 ; \\
\text { ПСРЛ ХІ, s. 215; ПСРЛ } \\
\text { ХVII, s. } 66\end{array}$ & $\begin{array}{l}\text { zjazd z udziałem Jagiełły, } \\
\text { Lingwena, Wasyla I, wiel- } \\
\text { kiego księcia twerskiego, } \\
\text { metropolity Focjusza, Dżelal- } \\
\text {-ed-Dina i in. (Gąsiorowski } \\
\text { 2015, s. 75; Mikulski 2011, } \\
\text { s. } 81-85 \text { ) }\end{array}$ \\
\hline $\mathrm{X}$ & $\begin{array}{l}\text { pierwsza } \\
\text { połowa (?) }\end{array}$ & Gliniany & $\begin{array}{l}\text { Dług. X-XI, } \\
\text { s. } 184-185^{271}\end{array}$ & $\begin{array}{l}\text { ponowne spotkanie } \\
\text { z Jagiełłą (Gąsiorowski 2015, } \\
\text { s. 75) }\end{array}$ \\
\hline $\mathrm{XI}$ & połowa & Lwów & $\begin{array}{l}\text { Dług. X-XI, s. } 185 \\
\text { LUB IV 1905, } 1906\end{array}$ & \\
\hline & & & 1412 & \\
\hline I & 17 & Wilno & CESXV II 45 & \\
\hline & 25 & Kowno & CEV 489 & \\
\hline IV & 15 & Troki $^{272}$ & $\begin{array}{l}\text { CEV } 492 \\
\text { LC I } 119 \\
\text { Kurtyka. Rep. } 120^{*} \\
\end{array}$ & \\
\hline & 17 & Troki $^{273}$ & CESXV II 49 & \\
\hline
\end{tabular}

całkiem logiczna. Albo Długosz pomylił Zasław z Mścisławiem, położonym niedaleko od Krzyczowa (ale wtedy władcy mieli z Mścisławia udać się do Krzyczowa, a nie odwrotnie; por. Mikulski 2011, s. 81, przyp. 222), albo mijali oni Zasław po drodze z Wilna do Połocka.

269 W CEV błędnie datowano na 23 VIII 1411 r. Dalej J. Purc notuje ponowne spotkanie Witolda z Jagiełłą w Kamieńcu Podolskim, powołując się na: L. Kolankowski, op. cit., s. 110, co jednak przeczy bezpośredniej wskazówce Długosza, że takie spotkanie odbyło się w Glinianach.

270 List wielkiego marszałka zakonnego do wielkiego mistrza w późniejszym streszczeniu ma jedynie datę dzienną - 21 lipca; 1411 r. jako datę roczną proponuje K. Kwiatkowski w artykule przygotowywanym do druku.

271 Potem Witold udał się na Litwę; Dług. X-XI, s. 185.

272 J. Purc zaznacza pobyt Witolda w Lubowli po 9 marca, z powołaniem się na: A. Prochaska, Dzieje Witolda..., s. 174, przyp. 4. Tę opinię przekonująco obalił J. Tęgowski; Tęgowski 2006, s. 70. Szczegółowa dokumentacja zjazdu zob. G. Schwedler, Herrschertreffen des Spätmittelalters: Formen - Rituale - Wirkungen, Ostfildern 2008 (Mittelalter-Forschungen, t. 21), s. 458-459 (R 183).

273 Według J. Purca ok. 15 maja Witold przebywał koło Ragnety (z powołaniem się na SD II 981, 983). W doniesieniu wielkiego mistrza o poselstwie komtura Ragnety do Witolda jest mowa o tym, że ten zbudował i umocnił zamki przy granicach z Prusami, ale brak informacji o miejscu jego pobytu; GStAPK, OBA $1772=$ CEV $494^{*}$. 


\begin{tabular}{|c|c|c|c|c|}
\hline \multicolumn{2}{|c|}{ Data } & \multirow{2}{*}{$\begin{array}{r}\text { Miejsce } \\
\text { Kowno }\end{array}$} & \multirow{2}{*}{\begin{tabular}{l}
\multicolumn{1}{c}{ Źródło } \\
Paravicini 1994, s. 925 \\
$=$ Rowell 2004, nr 8, \\
s. 171-172
\end{tabular}} & \multirow[t]{2}{*}{ Uwagi } \\
\hline $\mathrm{V}$ & 1 & & & \\
\hline & 31 & Troki & KDKW 57 & \\
\hline VI & & Litwa (?) & CEV, dod. $17^{274}$ & \\
\hline VII & & Litwa $^{275}$ & $\begin{array}{l}\text { GStAPK, OBA } 1772= \\
\text { CEV } 494^{*}\end{array}$ & \\
\hline IX & 28 & $\begin{array}{l}\text { nad Bugiem } \\
1 \text { milę od Hru- } \\
\text { bieszowa }\end{array}$ & Dług. X-XI, s. 208 & $\begin{array}{l}\text { spotkanie z Jagiełłą } \\
\text { (Gąsiorowski 2015, s. 77) }\end{array}$ \\
\hline $\mathrm{X}$ & 28 & Euck & Lites II, s. 230-231 & \\
\hline XI & 6 & $\begin{array}{l}\text { między Piń- } \\
\text { skiem a Lip- } \\
\text { skiem (?) }\end{array}$ & CEV $385^{276}$ & \\
\hline \multicolumn{2}{|c|}{$\begin{array}{l}\text { między } 6 \text { XI } \\
\text { a } 24 \text { XII }\end{array}$} & $\begin{array}{l}\text { Nowogródek } \\
\text { (?) }\end{array}$ & CEV 385 (plan) & \\
\hline XII & $23-25$ & Troki & $\begin{array}{l}\text { Lites II, s. 307; CEV 513, } \\
514\end{array}$ & $\begin{array}{l}\text { spotkanie z Zofią } \\
\text { Witoldówną }\end{array}$ \\
\hline \multicolumn{5}{|c|}{1413} \\
\hline \multirow[t]{3}{*}{ I } & 6 & Wilno & Dogiel IV 84 & \multirow[b]{3}{*}{$\begin{array}{l}\text { spotkanie z Jagiełłą, } 7 \text { I był } \\
\text { on w Mereczu, } 17 \text { I - w Tro- } \\
\text { kach, 22-27 I - w Kownie, } \\
\text { 6-7 II - w Wilnie (Gąsiorow- } \\
\text { ski 2015, s. 77) }\end{array}$} \\
\hline & 7 & Troki & HUB V 1090 & \\
\hline & 9 & $\begin{array}{l}\text { Worany, nowy } \\
\text { dwór myśliw- } \\
\text { ski nad rzeką } \\
\text { Mereczanką }\end{array}$ & CEV 519 & \\
\hline
\end{tabular}

274 O dacie zob. Jóźwiak 2004, s. 107.

${ }^{275}$ List mistrza inflanckiego Siegfrida Landera von Spanheim, który J. Purc przywołuje na potwierdzenie pobytu Witolda w Trokach 15 VII 1412 r. (CEV II 989 = IC I 654), w rzeczywistości należy datować na 15 VII 1416 r. (LUB V 2079 = CEV 683). Ten sam badacz twierdzi, że 12 VIII $1412 \mathrm{r}$. Witold przebywał w Brześciu, ale jak świetnie wykazał D. Antanavičius, odpowiedni przywilej jest falsyfikatem z 1501 r.; idem, 1380 ir 1412 m. Vytauto falsifikatu Bresto dvasininkams genezé, LIM, 2003 [2004], nr 1, s. 41-70 (tu w aneksie 1 też najnowsza edycja). Ponieważ lista świadków tego dokumentu została przejęta z przywileju Witolda dla mieszczan brzeskich, a liczne elementy formularza są anachroniczne, nie ma podstaw przypuszczać, że data pochodzi $\mathrm{z}$ jakiegoś oryginalnego dokumentu Witolda.

${ }^{276}$ List Witolda w oryginale ma tylko datę dzienną - 6 listopada (św. Leonard), w CEV umieszczony pod 1408 r., w zespole OBA - pod 1414 r.; treść nie pozwala wyznaczyć dokładnej datacji. Został on spisany przez pisarza określonego jako „ręka nr 6” oddziału łacińsko-niemieckiego kancelarii Witolda, poświadczonego w latach 1407-1421; R. Čapaite, Gotikinis kursyvas..., s. 335-345, 501, $\mathrm{nr} 61$. W liście jest wzmianka o jego spisaniu w drodze z Łucka do Nowogródka. Na tej podstawie hipotetycznie odnoszę ten list do 1412 lub 1415 r., kiedy Witold był w Łucku w październiku. 


\begin{tabular}{|c|c|c|c|c|}
\hline \multicolumn{2}{|c|}{ Data } & \multirow{2}{*}{\begin{tabular}{|l|}
\multicolumn{1}{|c}{ Miejsce } \\
Troki \\
\end{tabular}} & \multirow{2}{*}{\begin{tabular}{|r|} 
Źródło \\
Lites II, s. $80-81$ \\
\end{tabular}} & \multirow[t]{2}{*}{ Uwagi } \\
\hline & 17 & & & \\
\hline & $19-20$ & $\begin{array}{l}\text { Kowno (plan - } \\
\text { do } 2 \text { II) }\end{array}$ & $\begin{array}{l}\text { CEV 516*, 519; Lites II, } \\
\text { s. 78-79; BGDO II } 74 \\
\text { (Anm. 9), } 75\end{array}$ & \\
\hline & 25 & Kowno & CEV $525^{*}$ & \\
\hline & $28^{277}$ & Kowno & Lites II, s. 83-84 & \\
\hline \multirow[t]{2}{*}{ II } & 6 & Wilno & Lites II, s. 82 & \\
\hline & $\begin{array}{l}\text { między } 6 \\
\text { a } 24\end{array}$ & wyspa Salin ${ }^{278}$ & CEV 529 & \\
\hline IV & & $\begin{array}{l}\text { Witebsk (przy- } \\
\text { jazd rzeką } \\
\text { Dźwiną) }\end{array}$ & BC I 10, s. $27-28$ & \\
\hline $\mathrm{V}$ & początek & Wielona (?) & CEV $546^{*}$ & \\
\hline \multirow[t]{2}{*}{ VII } & $8^{280}$ & Wilno (plan) & GStAPK, OBA 1469 & $\begin{array}{l}\text { plany wyprawy na władz- } \\
\text { two zakonne lub Nowogród } \\
\text { Wielki }\end{array}$ \\
\hline & $\begin{array}{l}13 \text { i wcześ- } \\
\text { niej }\end{array}$ & $\begin{array}{l}\text { nad rzeką } \\
\text { Bugiem }\end{array}$ & GStAPK, OBA 1971 & \\
\hline \multirow[t]{2}{*}{$\mathrm{X}$} & 2 & Horodło & AUPL 51 & \multirow{4}{*}{$\begin{array}{l}\text { spotkanie z Jagiełłą: jego } \\
\text { pobyt w Horodle poświad- } \\
\text { czony } 2-4 \text { X, potem z Witol- } \\
\text { dem udał się na Żmudź } \\
\text { i Litwę, gdzie przebywał } \\
\text { do początków } 1414 \text { r. } \\
\text { (Gąsiorowski } 2015, \text { s. } 79 \text { ) }\end{array}$} \\
\hline & 25 & Merecz & CEV 563 & \\
\hline \multirow[t]{2}{*}{ XI } & ok. 11 & Kowno & Dług. XI, s. 21 & \\
\hline & po 11 & $\left|\begin{array}{l}\text { Żmudź (podróż } \\
\text { Niemnem } \\
\text { i Dubissą [?]) } 281\end{array}\right|$ & Dług. XI, s. 21 & \\
\hline
\end{tabular}

277 List Witolda z Wilna z 31 stycznia, na który powołuje się J. Purc (CEV 527* = ПГ I 37), odnosi się do $1397 \mathrm{r}$.

278 O datacji zob. CEV, s. 257-258. W liście wielkiego mistrza krzyżackiego do mistrza inflanckiego z lutego 1413 r. jest mowa o pertraktacjach „u Kowna” (LUB IV 1932). J. Tęgowski odnotowuje pobyt Witolda w Dubiczach 16 III 1413 r., jednak dokument, na który się powołuje (Vitoldiana 86), pochodzi najprawdopodobniej z 24 II 1396 lub 5 III 1411 r. J. Purc odnotowuje pobyt Witolda w Dubiczach 29 III 1413 r., ale list, na który się powołuje (CEV 538 ${ }^{\star}=$ ПГ I 43), pochodzi z 1402 lub 1403 r.

${ }^{279}$ List Witolda, na który powołuje się J. Purc na potwierdzenie jego pobytu w Grodnie 16 IV 1413 (GStAPK, OBA $1676=$ CEV 540*), w rzeczywistości pochodzi z 1411 r. (zob. wyżej, przyp. 264).

${ }^{280}$ O dacie zob. Jóźwiak 2004, s. 18.

${ }^{281}$ Niewykluczone, że podróż Witolda i Jagiełły na Żmudź została wymyślona przez Długosza: do szczegółowej argumentacji (D. Baronas, S.C. Rowell, op. cit., s. 342-347) można dodać słowa posła krzyżackiego o złych drogach, którymi jechał on do Witolda i Jagiełły do Trok w listopadzie tego samego roku (GStAPK, OBA $2012=$ CEV 567*). J. Purc odnosi do tego czasu pobyt Witolda w Połądze, ale na potwierdzenie powołuje się na źródło z 1428 r. (CEV 1313). 


\begin{tabular}{|c|c|c|c|c|}
\hline \multicolumn{2}{|c|}{ Data } & \multirow{3}{*}{$\begin{array}{l}\text { Miejsce } \\
\text { Troki } \\
\text { Wilno } 282\end{array}$} & \multirow{3}{*}{\begin{tabular}{l}
\multicolumn{1}{c}{ Źródło } \\
GStAPK, OBA $2012=$ \\
CEV 567*
\end{tabular}} & \multirow[t]{3}{*}{ Uwagi } \\
\hline \multirow[t]{2}{*}{ XI } & $19-22$ & & & \\
\hline & 22 & & & \\
\hline \multicolumn{5}{|c|}{1414} \\
\hline \multirow[t]{2}{*}{ I } & 4 & Wilno & CEV 571 & \\
\hline & $\begin{array}{l}\text { między } 4 \\
\text { a } 31^{283}\end{array}$ & $\begin{array}{l}\text { zamek nad } \\
\text { Niemnem } \\
\text { w odległości } \\
5 \text { mil od Trok } \\
\text { - Punia (?) } \\
(\text { Posur, Pous- } \\
\text { seur })^{284}\end{array}$ & Klimas 1933, s. 153 & \\
\hline III & 13 & Berszty & CEV 574 & \\
\hline \multirow[t]{3}{*}{ IV } & $8 / 9$ & Step (?) & GStAPK, OBA $591^{285}$ & \\
\hline & 21 & Wizna & CEV 583 & \\
\hline & $29^{286}$ & Troki & CEV 583 & \\
\hline \multicolumn{2}{|c|}{ wiosna (V?) } & Litwa & $\begin{array}{l}\text { НПЛ, s. 404-405; } \\
\text { ПСРЛ ІV/1, s. } 413\end{array}$ & \\
\hline $\mathrm{V}$ & 29 & Troki & GStAPK, OBA 2167 & \\
\hline \multirow[t]{2}{*}{ VI } & 5 & Troki $^{287}$ & CEV 613 & \\
\hline & 25 & Worany & CEV 588 & \\
\hline
\end{tabular}

${ }^{282}$ Wbrew opinii J. Purca, Ghillebert de Lannoy nie wspomina o pobycie Witolda w Wilnie pod koniec $1413 \mathrm{r}$.

283 Przed 24 II 1414 r. Ghillebert de Lannoy przez Kowno, Ragnetę, Królewiec i Gdańsk już dojechał do Malborka; Regesten zu den Briefregistern des Deutschen Ordens, t. 2: Die Ordensfolianten 8, 9 und Zusatzmaterial. Mit einem Anhang: Die Abschriften aus den Briefregistern des Folianten APG 300, R/Ll, 74, oprac. S. Kubon, J. Sarnowsky, A. Souhr-Könighaus, Göttingen 2014 (Beihefte zum Preußischen Urkundenbuch, t. 2), s. 76, nr 2.

${ }^{284}$ W sprawie identyfikacji tej miejscowości, w której Witold przyjął Ghilleberta de Lannoy, zob. Klimas 1933, s. 121-124; Kraštas ir žmonés..., s. 50, przyp. 4. J. Purc za J. Fijałkiem widział w nim Dorsuniszki (zob. J. Fijałek, Dorsuniszki, „Kwartalnik Historyczny” 44, 1930, nr 1, s. 336), natomiast J. Kunigielis opowiada się za Mereczem; eadem, Litewskie miasta $w$ relacji Gilberta de Lanпоу z rokи 1414, w: Вялікае Княства Літоўскае: палітыка, эканоміка, культура, red. А.А. Скеп'ян, Мінск 2017, s. 42-43.

285 Edycja tego listu z obszernym wyjaśnieniem datacji zob. С.В. Полехов, Лугвенъ..., s. 58-78.

286 J. Purc odnotowuje pobyt Witolda w Brodnicy 30 IV 1414 r. (z powołaniem na list Witolda zachowany w oryginale: CEV 630), ale wszystko przemawia za tezą J. Tęgowskiego, że pisarz pomylił się w dacie (zob. niżej).

287 J. Purc odnotowuje pobyt Witolda w Kownie 23 VI 1414 r., z powołaniem na jego list do namiestnika żmudzkiego Kieżgajły i ciwunów kołtyniańskich o nadaniu chłopów; Jablonskis 1933, s. 383. Jednak dokument ten zachował się w późnych odpisach i nie ma dokładnej daty. J. Ochmański datował go na 22 VI 1415 r. (zob. niżej). 


\begin{tabular}{|c|c|c|c|c|}
\hline \multicolumn{2}{|c|}{ Data } & \multirow{2}{*}{$\frac{\text { Miejsce }}{\text { Zakroczym }^{288}}$} & \multirow{2}{*}{$\frac{\text { Źródło }}{\text { Dług. XI, s. 33-35 }}$} & \multirow[t]{2}{*}{ Uwagi } \\
\hline VII & $17-24$ & & & \\
\hline \multicolumn{2}{|c|}{25 lub 28 VII-7 VIII } & Nidzica & $\begin{array}{l}\text { Dług. XI, s. 35; SRP III, } \\
\text { s. } 341\end{array}$ & \multirow{15}{*}{$\begin{array}{l}\text { wojna Polski i Litwy z zako- } \\
\text { nem krzyżackim; itinerarium } \\
\text { Witolda dla tego okresu } \\
\text { odtworzone jest umownie, } \\
\text { na podstawie itinerarium } \\
\text { Jagiełły (Gąsiorowski } 2015, \\
\text { s. } 81 \text { ) i danych o działaniach } \\
\text { wojennych (Biskup 1993, } \\
\text { s. 100-114) }\end{array}$} \\
\hline \multirow{6}{*}{\multicolumn{2}{|c|}{ między 7 a 3 VIII }} & Olsztynek & \multirow{6}{*}{$\begin{array}{l}\text { Dług. XI, s. } 35-38 \text {; } \\
\text { SRP III, s. } 343\end{array}$} & \\
\hline & & Olsztyn & & \\
\hline & & Dobre Miasto & & \\
\hline & & $\begin{array}{l}\text { Lidzbark War- } \\
\text { miński }\end{array}$ & & \\
\hline & & Krzyżpork & & \\
\hline & & Pasłęk & & \\
\hline \multirow[t]{6}{*}{ IX } & początek & Elbląg & Dług. XI, s. 38 & \\
\hline & $7-9$ & Dzierzgoń & \multirow{3}{*}{$\begin{array}{l}\text { Dług. XI, s. } 38-39 \text {; } \\
\text { SRP III, s. } 345\end{array}$} & \\
\hline & ok. $10(?)$ & Prabuty & & \\
\hline & ok. 10 (?) & Biskupiec & & \\
\hline & 14 & pod Brodnicą & Dług. XI, s. 39 & \\
\hline & 24 & pod Brodnicą & CEV $630^{289}$ & \\
\hline \multirow[t]{2}{*}{$\mathrm{X}$} & 7 & pod Brodnicą & CEV 599* & \\
\hline & 8 & pod Brodnicą & CEV $600^{290}$ & \\
\hline \multirow[t]{2}{*}{ XII } & $16-17^{291}$ & Grodno & CEV 610, 611 & \\
\hline & 25 & Grodno $^{292}$ & Dług. XI, s. 44-45 & $\begin{array}{l}\text { spotkanie z Jagiełłą poświad- } \\
\text { czonym na Litwie od końca } \\
\text { grudnia } 1414 \text { do połowy } \\
\text { stycznia } 1415 \text { r. }\end{array}$ \\
\hline
\end{tabular}

${ }^{288}$ M. Biskup datuje połączenie wojsk Witolda i Jagiełły na 24 VII 1414 r.; Biskup 1993, s. 100. 5 VIII 1414 r. komtur Nieszawy pisał o pobycie sojuszników pod Raciążem (na Mazowszu, ok. 54 km na północny zachód od Zakroczymia), ale nie do końca jest jasne, kogo dotyczą te słowa Witolda z Jagiełłą czy księcia opolskiego: „Ouch, als ich euwern gnoden habe geschreben, das sie [Jagiełło i Witold - S.P.] stark an der grenicz legen; nu sie sich noch starker haben gesammelt und legen[,] no czum Radczans, leyt der herczog von Opeln mit eime grossen huffen, und legen alumme, do das ich nicht gutes mich mag vorsten", GStAPK, OBA 2123.

289 W CEV i u J. Purca pod datą 30 IV 1414 r. J. Tęgowski na podstawie itinerarium Witolda wykazał, że ta datacja jest błędna i zaproponował nową: najprawdopodobniej pisarz pomyłkowo podał imię ewangelisty Marka zamiast Mateusza. Opowiadanie Długosza o odejściu Witolda spod Brodnicy przed Jagiełłą (Dług. XI, s. 39-40) da się obalić na podstawie itinerarium wielkiego księcia.

290 J. Tęgowski dopatruje się w dokumencie z 1425 r. (Urkundenbuch des Bisthums Culm, t. 2, wyd. C.P. Woelky, Danzig 1885, nr 530) wskazówki na pobyt Witolda i Jagiełły pod Toruniem w czasie wojny 1414 r.; Tęgowski 2006, s. 71. W rzeczywistości jest tam mowa o obawie przed ich dotarciem tam, podczas gdy marsz w tym kierunku jest sprzeczny z itinerariami obu władców.

${ }^{291}$ Datację uściśliła R. Čapaitè, Gotikinis kursyvas..., s. 501, nr 62, 63.

292 J. Purc odnotowuje pobyt Witolda w Wilnie 27 XII 1414 r., powołując się na błędną datację jego dokumentu z 4 I 1414 r. (zob. wyżej), zaproponowaną przez K.E. Napiersky’ego (IC I 698). 


\begin{tabular}{|c|c|c|c|c|}
\hline \multicolumn{2}{|c|}{ Data } & \multirow[t]{2}{*}{ Miejsce } & \multirow[t]{2}{*}{ Źródło } & \multirow{2}{*}{\begin{tabular}{|c|c|}
\multicolumn{1}{c}{ Uwagi } \\
$($ LUB V 1992; Gąsiorowski \\
2015$, s. 82 $)^{293}$
\end{tabular}} \\
\hline & & & & \\
\hline \multicolumn{5}{|c|}{1415} \\
\hline \multirow[t]{2}{*}{ I } & 13 & Dowgi & CEV 616, 617, 618 & \\
\hline & 19 & Troki & CEV 619 & \\
\hline \multirow[t]{2}{*}{ II } & 14 & Troki & KDKW 60 & \\
\hline & 23 & Troki & KDKW 67a & \\
\hline \multirow[t]{3}{*}{ III } & 6 & Dubicze & CEV 623 & \\
\hline & & Litwa & CEV 629 & \\
\hline & ok. 25 & Grodno & ПСРЛ ХХХV, s. 55 & \\
\hline \multirow[t]{2}{*}{ IV } & 8 & Grodno & Jablonskis 1933, s. 406 & \\
\hline & 22 & Troki & KDKW 67 & \\
\hline $\mathrm{V}$ & 28 & Troki & CEV 635 & \\
\hline \multirow[t]{2}{*}{ VI } & 13 & Troki & CEV $636^{*}$; LUB V $2009^{294}$ & \multirow{4}{*}{$\begin{array}{l}\text { spotkanie z Jagiełłą, który } \\
\text { dokonał objazdu WKL } \\
\text { w czerwcu - początkach } \\
\text { sierpnia } 1415 \text { r. (Gąsiorowski } \\
\text { 2015, s. } 82 \text { ) } \\
\end{array}$} \\
\hline & 22 & Kowno & Vitoldiana 89 & \\
\hline \multirow[t]{3}{*}{ VII } & $2-3$ & Miedniki & CEV 638 & \\
\hline & $\begin{array}{l}\text { między } \\
3 \text { a } 27\end{array}$ & Kijów 295 & $\begin{array}{l}\text { CEV } 643 \text { = LUB V 2014; } \\
\text { por. CEV } 639=\text { LUB V } \\
2012 \text { (plan pertraktacji } \\
\text { z chanem tatarskim) }\end{array}$ & \\
\hline & po $27-30$ & Nowogródek & CEV 643 = LUB V 2014 & \\
\hline VIII & 5 & Nowogródek ${ }^{296}$ & CEV 644 & \\
\hline \multirow[t]{2}{*}{ IX } & & Dobrostany & Dług. XI, s. 56 & $\begin{array}{l}\text { spotkanie z Jagiełłą poświad- } \\
\text { czonym w Dobrostanach } \\
\text { 18-19 IX } 1415 \text { (Gąsiorowski } \\
2015 \text {, s. } 83 \text { ) }\end{array}$ \\
\hline & $21-22$ & Brześć & CEV 649 & \\
\hline
\end{tabular}

${ }^{293}$ Zapewne informacja Długosza, że Jagiełło, przebywając na Litwie zimą 1414/1415 r., unikał spotkania z Witoldem, urażony jego przedwczesnym wycofaniem się z Prus, nie do końca odpowiada rzeczywistości.

294 Dokument mistrza inflanckiego Dietricha Torka z obietnicą przeprowadzenia zjazdu z Witoldem i Jagiełłą nad Wisłą w pobliżu wsi Słońsko na Kujawach 7 VI 1416 r., wystawiony w Trokach, co pośrednio wskazuje na obecność tam Witolda.

295 J. Purc odnotowuje pobyt Witolda w Łucku, powołując się na CEV 631, choć list ten pochodzi z $1417 \mathrm{r}$.

296 J. Purc odnotowuje pobyt Witolda w Opatowie 10 VIII 1415 r., z powołaniem się na IA 853, gdzie z kolei mamy odsyłacz do wydawnictwa: Rerum Concilii Constantiensis, t. 3, wyd. H. von der Hardt, Francofurti-Lipsiae 1698, s. 6. Jednak tam jest drukowany znany memoriał wystawiony w Opatowie 10 VIII 1409 r.; Lites II, s. 436; Gąsiorowski 2015, s. 66. 


\begin{tabular}{|c|c|c|c|c|}
\hline \multicolumn{2}{|c|}{ Data } & Miejsce & Źródło & Uwagi \\
\hline \multirow[t]{2}{*}{$\mathrm{X}$} & 9 & Euck & CEV 649 (plan), 650 & \\
\hline & 18 & Lwów & CEV 651 & $\begin{array}{l}\text { spotkanie z Jagiełłą } \\
\text { (Gąsiorowski 2015, s. 83) }\end{array}$ \\
\hline \multirow[t]{5}{*}{ XI } & 6 & $\begin{array}{l}\text { między } \\
\text { Pińskim } \\
\text { a Lipskiem (?) }\end{array}$ & CEV $385^{297}$ & \\
\hline & $15-16$ & Nowogródek & $\begin{array}{l}\text { АЗР I 25; Афанасенко } \\
\text { 2015, s. 119-122 }\end{array}$ & $\begin{array}{l}\text { synod biskupów Rusi } \\
\text { zachodniej, powołanie } \\
\text { Grzegorza Camblaka na } \\
\text { metropolię }\end{array}$ \\
\hline & 18 & Troki (plan) & CEV 650 & \\
\hline & 22 & Wilno & CEV 652 & \multirow{2}{*}{$\begin{array}{l}\text { spotkanie z Jagiełłą poświad } \\
\text { czonym na Litwie od końca } \\
1415 \text { do początków lutego } \\
1416 \text { r. (Gąsiorowski 2015, } \\
\text { s. } 83 \text { ) }\end{array}$} \\
\hline & 24 & Troki & $\begin{array}{l}\text { GStAPK, OBA } 540= \\
\text { LUB IV } 1467^{298}\end{array}$ & \\
\hline \multicolumn{5}{|c|}{1416} \\
\hline \multirow[t]{4}{*}{ I } & 6 & Wilno & LUB V $2047=$ CEV $657^{*}$ & \\
\hline & 7 & Worany & CEV 658 & \\
\hline & $\begin{array}{l}\text { między } 7 \\
\text { a } 26\end{array}$ & $\begin{array}{l}\text { koło Trok } \\
\text { (plan) }\end{array}$ & CEV 658 & \\
\hline & 26 & Troki & Vitoldiana 90 & \\
\hline \multirow[t]{3}{*}{ II } & 6 & Wilno & $\begin{array}{l}\text { Stelmach 1981, nr 2, } \\
\text { s. } 16-17\end{array}$ & \\
\hline & 23 & Troki & KDKW 67a & \\
\hline & 25 & Troki & $\begin{array}{l}\text { Sochaniewicz 1925-1926, } \\
\text { s. } 385^{299}\end{array}$ & \\
\hline \multicolumn{2}{|c|}{ między 25 II a 21 IV } & Grodno & CEV 666 & \\
\hline IV & 21 & Przewałka & CEV 666 & \\
\hline \multicolumn{2}{|c|}{ między $21 \mathrm{IV}$ a $8 \mathrm{~V}$} & Kowno ${ }^{300}$ & CEV 666 & \\
\hline
\end{tabular}

List Witolda hipotetycznie datowany na rok 1412 lub 1415; zob. wyżej, przyp. 276.

298 O datacji listu zob. С.В. Полехов, Браки князя Свидригайла Ольгердовича, w: По тюбви, въ правду, безо всякие хитрости, Москва 2014, s. 249-250.

${ }^{299}$ Jako źródło wskazane: „Z transumptu Jana III z 22/4 1688 wystawionego w Wilnie”, bez uściślenia treści i miejsca przechowywania dokumentu.

300 Witold już w marcu planował być w Kownie 8 dni po św. Jerzym; ОР РГБ, f. 68, d. 358.5, k. 28 ob. - list wielkiego mistrza do Witolda z 29 III 1416 r., według niezachowanego odpisu z archiwum królewieckiego; GStAPK, OF 8, s. 289. 


\begin{tabular}{|c|c|c|c|c|}
\hline \multicolumn{2}{|c|}{ Data } & Miejsce & Źródło & Uwagi \\
\hline \multirow[t]{2}{*}{ V } & 8 & Wielona (plan) & CEV 666 & \\
\hline & 19 & Troki $^{301}$ & CEV 671 & \\
\hline VI & ok. 7 & Troki (plan) & CEV 671 & \\
\hline VII & 1 & $\begin{array}{l}\text { Łyngmiany } \\
\text { (plan) }\end{array}$ & LUB V 2072, 2074 & \\
\hline \multirow[t]{2}{*}{ VII } & 12 & Litwa (Troki?) & \multirow[t]{2}{*}{ LUB V 2079 = CEV 683} & \multirow{2}{*}{$\begin{array}{l}\text { spotkanie z mistrzem inflanc- } \\
\text { kim (zob. też BGDO II 182) }\end{array}$} \\
\hline & $14-15$ & Troki $^{302}$ & & \\
\hline \multirow[t]{2}{*}{ VIII } & 16 & Nowogródek & CEV 688 & \\
\hline & 17 & Nowogródek & CEV 689 & \\
\hline \multirow[t]{3}{*}{ IX } & 6 & Worany & CEV 696 & \\
\hline & 8 & Worany & CEV 698 & \\
\hline & 17 & Kiełczewice & SHRM $214=$ CEV $700^{*}$ & \\
\hline \multirow[t]{4}{*}{$\mathrm{X}$} & 10 & Grodno & AS I 24 = Vitoldiana 74 & \\
\hline & $\begin{array}{l}\text { między } 10 \\
\text { a } 15\end{array}$ & Dubno & Dług. XI, s. 61 & \\
\hline & $15-17^{303}$ & $\begin{array}{l}\text { nad Niemnem } \\
\text { koło Wielony }\end{array}$ & $\begin{array}{l}\text { CEV 703*; BGDO II 180; } \\
\text { Dług. XI, s. 61-62 }\end{array}$ & \multirow{4}{*}{$\begin{array}{l}\text { spotkanie z Jagiełłą poświad- } \\
\text { czonym w WKL do początku } \\
\text { stycznia } 1417 \text { r. (Gąsiorowski } \\
\text { 2015, s. } 85 \text { ) }\end{array}$} \\
\hline & 17 & Kowno $^{304}$ & CEV 704 & \\
\hline XI & 2 & Wilno & CEV 710 & \\
\hline XII & 24 & Troki & KDKW 69 & \\
\hline \multicolumn{5}{|c|}{1417} \\
\hline I & przed 20 & Krewo & LUB V 2113 & \\
\hline
\end{tabular}

${ }^{301}$ J. Purc odnotowuje pobyt Witolda we Włocławku (błędnie, ponieważ w dokumencie wymieniony Inowrocław - „Datum in Juni Wladislauia”) 25 VI 1416 r., powołując się na CEV 672. W rzeczywistości w Inowrocławiu w tym czasie przebywali Władysław Jagiełło i jego doradcy, którzy prowadzili pertraktacje o przedłużeniu rozejmu i wystawili stosowny dokument także w imieniu Witolda. 1 VI 1416 r. wielki mistrz pisał do Witolda o wcześniejszych negocjacjach odbytych w Gniewkowie (CEV 674).

${ }^{302}$ Data listu mistrza inflanckiego. Zapewne Witold także przebywał w Trokach. J. Purc odnotowuje pobyt Witolda na pograniczu pruskim w lipcu 1416 r., z powołaniem się na pracę: Sochaniewicz 1925-1926, s. 385, gdzie jednak brak informacji o tym.

${ }^{303} \mathrm{Na}$ pertraktacjach mistrza inflanckiego z Witoldem latem i jesienią $1416 \mathrm{r}$. omawiano zjazd „za 14 dni po św. Michale", czyli 13 października; LUB V 2079; S. Kubon, Wiederaufgefundene Quellen des Deutschen Ordens aus der Zeit des Konstanzer Konzils vorwiegend zur Auseinandersetzung mit Polen-Litauen, „Jahrbuch für die Geschichte Mittel- und Ostdeutschlands” 61, 2015, nr 11, s. 28. Oficjał pomezański wymienia tę samą datę, natomiast Długosz - „dzień św. Jadwigi”; SRP III, s. 364-365; Dług. XI, s. 61.

304 J. Purc odnotowuje pobyt Witolda w Kownie także 21 października, ale powołuje się przy tym na dane o podróżach Jagiełły. 


\begin{tabular}{|c|c|c|c|c|}
\hline \multicolumn{2}{|c|}{ Data } & Miejsce & Źródło & Uwagi \\
\hline \multicolumn{2}{|c|}{ I - 22 II } & Ruś & CEV 716 & \\
\hline \multirow[t]{2}{*}{ II } & 19 & Utukini (?) $)^{305}$ & Vitoldiana 92 & \\
\hline & 22 & Troki & CEV 716 & \\
\hline \multirow[t]{2}{*}{ III } & 27 & Troki & CEV 718 & \\
\hline & $\begin{array}{l}31 \\
\text { i wcześniej }\end{array}$ & Litwa & LUB V 2126 & \\
\hline IV & $\begin{array}{l}11 \text { i wcześ- } \\
\text { niej }\end{array}$ & Grodno & CEV 723 & \\
\hline \multirow[t]{3}{*}{ V } & 7 & Euck & $\begin{array}{l}\text { LUB V } 2140= \\
\text { CEV } 729^{\star} ; \text { CEV } 631^{306}\end{array}$ & \multirow{2}{*}{$\begin{array}{l}\text { spotkanie z Jagiełłą - Gąsio- } \\
\text { rowski } 2015 \text {, s. } 86 \text { (odno- } \\
\text { towano jego pobyt na Rusi } \\
\text { koronnej w kwietniu - lipcu } \\
1417 \text { r.) }\end{array}$} \\
\hline & 16 & $\begin{array}{l}\text { nad rzeką } \\
\text { Bugiem mię- } \\
\text { dzy Łuckiem } \\
\text { a Lwowem } \\
\end{array}$ & CEV 724 & \\
\hline & 17 & $\begin{array}{l}\text { Dobrotwór nad } \\
\text { Bugiem }\end{array}$ & CEV $724^{307}$ & $\begin{array}{l}\text { w tym samym liście stwier- } \\
\text { dza, że niedługo przyjedzie } \\
\text { na Litwę }\end{array}$ \\
\hline \multirow[t]{3}{*}{ VI } & 6 & Troki (plan) & CEV 631 & \\
\hline & 13 & Brześć & $\begin{array}{l}\text { BPAN, rkps } 8822 \text {, z. II, } \\
\text { s. } 79 \text { = Jaszczołt (przyg.), } \\
\text { nr } 2\end{array}$ & \\
\hline & 27 & Wilno ${ }^{308}$ & CEV 734 & \\
\hline VIII & 22 & Wilno $(?)^{309}$ & LUB V $2158=$ CEV 739* & \\
\hline
\end{tabular}

${ }^{305} \mathrm{~W}$ odpisie siedemnastowiecznym data znacznie zniekształcona, zrekonstruowana hipotetycznie przez K. Jablonskisa (Jablonskis 1933, s. 427-428); w niniejszym itinerarium uwzględniono poprawkę J. Ochmańskiego.

306 W edycji datowano na 6 V 1415 r. ze względu na wzmiankę o soborze w Konstancji. Nowa datacja na podstawie informacji o spotkaniu Witolda i Jagiełły w Łucku.

307 Długosz datuje spotkanie Witolda i Jagiełły w Dobrotworze na 24 czerwca, co nie zgadza się z ich itinerariami; Dług. XI, s. 73; Gąsiorowski 2015, s. 86, przyp. 200.

308 J. Purc odnotowuje także pobyt Witolda w Wilnie 24 VI 1417 r., ale odsyłacz do pracy J. Fijałka prowadzi do tego samego dokumentu. Odnotowuje też pobyt Witolda w Toruniu 15 VIII 1417 r. Możliwość spotkania z nim albo jego posłami w celu kolejnego przedłużenia rozejmu przewidywał dokument mistrza inflanckiego z 13 czerwca (LUB IV $2144=$ CEV 732 $)$, ale po jego zatwierdzeniu przez Zygmunta Luksemburskiego, o którym w Malborku dowiedzieli się 12 czerwca (SVDO I 122), pertraktacje zostały przerwane.

${ }^{309}$ W tym dniu w Wilnie odbył się ślub kniazia Olelki Włodzimierzowicza i Anastazji, córki Wasyla I. Ponieważ taka uroczystość na pewno nie odbyłaby się bez udziału Witolda, zapewne był on tam wówczas obecny. 


\begin{tabular}{|c|c|c|c|c|}
\hline \multicolumn{2}{|c|}{ Data } & \multirow{2}{*}{\begin{tabular}{|r|} 
Miejsce \\
$\begin{array}{l}\text { Nowy Kor- } \\
\text { czyn }(?)^{310}\end{array}$
\end{tabular}} & \multirow{2}{*}{\begin{tabular}{l}
\multicolumn{1}{c}{ Źródło } \\
Grabski 1966, s. 277-284 \\
$=$ Kłoczowski 1992, \\
s. $175-179=$ CM I 11
\end{tabular}} & \multirow[t]{2}{*}{ Uwagi } \\
\hline & 25 & & & \\
\hline \multirow[t]{3}{*}{$\mathrm{X}$} & $\begin{array}{l}15 \text { i wcześ- } \\
\text { niej }^{311}\end{array}$ & Kowno & $\begin{array}{l}\text { GStAPK, OBA } 2589= \\
\text { CM I } 12\end{array}$ & \\
\hline & 16 & Troki & Liedtke 1932, s. $148-149$ & \\
\hline & $23-24$ & Troki & $\begin{array}{l}\text { CM I } 13=\text { KDKW } 70= \\
\text { Jablonskis } 1933 \text {, s. } 400- \\
-401 \text {; CM I } 15=\text { KDKW } \\
72=\text { Jablonskis } 1933 \text {, } \\
\text { s. } 401-402 \text {; CEV } 743\end{array}$ & \\
\hline \multicolumn{2}{|c|}{$\begin{array}{l}\text { między } 24 \mathrm{X} \\
\text { a } 17 \text { XII }\end{array}$} & Żmudź & $\begin{array}{l}\text { CM I } 17=\text { CEV 744; } \\
\text { CM I } 22=\text { LUB V } 2177\end{array}$ & \\
\hline \multirow[t]{5}{*}{ XII } & 19 & Troki & CEV 754 & \\
\hline & \multirow{2}{*}{$\begin{array}{l}\text { między } 19 \\
\text { a } 26\end{array}$} & Mielnik (plan) & Liedtke 1932, s. 148 & \multirow{4}{*}{$\begin{array}{l}\text { spotkanie z Jagiełłą poświad- } \\
\text { czonym na Litwie w końcu } \\
\text { grudnia } 1417 \text { - na początku } \\
\text { stycznia } 1418 \text { r. (Gąsiorowski } \\
2015, \text { s. } 87 \text { ) }\end{array}$} \\
\hline & & Goniądz (?) & CEV 755 & \\
\hline & 26 & Troki & CEV 755 & \\
\hline & 28 & $\begin{array}{l}\text { Worany, dwór } \\
\text { myśliwski } \\
\text { (plan) }\end{array}$ & CEV 755 & \\
\hline \multicolumn{5}{|c|}{1418} \\
\hline \multirow[t]{2}{*}{ I } & 8 & Litwa (plan) & Liedtke 1932 , s. 148 & \\
\hline & 20 & Troki & $\begin{array}{l}\text { Codex diplomaticus } \\
\text { Silesiae, t. 6: Registrum } \\
\text { St. Wenceslai, Breslau } \\
1865, \mathrm{nr} 147^{\star}\end{array}$ & \\
\hline \multirow[t]{3}{*}{ II } & 3 & Troki & CESXV II 89 & \\
\hline & 19 & Worany & CEV 763 & \\
\hline & 21 & Dubicze & $\begin{array}{l}\text { AGAD, terr. Droh. } 2 \text {, } \\
\text { k. } 488-488 \mathrm{v}=\text { Jaszczołt } \\
\text { (przyg.), nr } 3\end{array}$ & \\
\hline IV & przed 10 & Troki & CEV $766^{312}$ & \\
\hline
\end{tabular}

310 Do końca niejasne miejsce pobytu Witolda 25 VIII 1417 r. Obecnie przyjmuje się, że list Jagiełły i Witolda na sobór w Konstancji został wystawiony w Nowym Mieście Korczynie (Gąsiorowski 2015, s. 87), ale niewykluczone, że faktycznie w tym dniu przebywał tam tylko Jagiełło, który wysłał list także w imieniu Witolda.

31110 X 1417 r. w Kownie przebywał i stąd pisał do wielkiego mistrza służący Witoldowi książę śląski Konrad Biały; GStAPK, OBA 2585. Może i sam Witold wtedy już przebywał w Kownie.

$312 \mathrm{~W}$ tym samym liście komtur Dyneburga donosił mistrzowi inflanckiemu, że Witold z obawy przed zdradą po ucieczce Świdrygiełly z więzienia w Krzemieńcu zamierza pozostawać 


\begin{tabular}{|c|c|c|c|c|}
\hline \multicolumn{2}{|c|}{ Data } & Miejsce & Źródło & Uwagi \\
\hline \multirow[t]{2}{*}{ VI } & 2 & Ejragoła & CEV 778, 781 & \\
\hline & 11 & Troki & CEV $781^{313}$ & \\
\hline VII & 31 & Troki (?) $)^{314}$ & \multirow{2}{*}{$\begin{array}{l}\text { Dług. XI, s. 87; SRP III, } \\
\text { s. } 376 \text {, przyp. 7; LUB V } \\
2267\end{array}$} & \\
\hline \multirow[t]{3}{*}{ VIII } & początek & Wilno & & \\
\hline & do 15 & $\begin{array}{l}\text { koło } \\
\text { Eucka (?) })^{315} \\
\end{array}$ & GStAPK, OBA 27929 & \\
\hline & & $\begin{array}{l}\text { Dawidgródek } \\
(?)\end{array}$ & Kurtyka. Rep. $165^{\star 316}$ & \\
\hline \multirow[t]{2}{*}{ IX } & 8 & Worany & $\begin{array}{l}\text { Vitoldiana } 94 \\
=\text { Kurtyka. Rep. } 129^{*}\end{array}$ & \\
\hline & 8 & Troki & CEV 796 & \\
\hline $\mathrm{X}$ & przed 9 & $\begin{array}{l}\text { między Tro- } \\
\text { kami a Siemie- } \\
\text { liszkami }\end{array}$ & CEV 796 = LUB V 2274 & \\
\hline
\end{tabular}

w Trokach jeszcze przez 12 tygodni, czyli mniej więcej do końca czerwca. To może służyć jako dodatkowy argument na potwierdzenie tezy, że Witold nie wziął osobistego udziału w pertraktacjach z posłami krzyżackimi w Brześciu Kujawskim 26 kwietnia, gdzie był obecny król polski; SVDO I $129=$ CESXV I $49=$ CEV 770*; Szweda 2009, s. 388; Gąsiorowski 2015, s. 88. J. Purc odnotowuje pobyt Witolda w Inowrocławiu $28 \mathrm{~V} 1418 \mathrm{r}$., powołując się na glejt dla mistrzów wielkiego krzyżackiego $\mathrm{i}$ inflanckiego na zjazd $\mathrm{w}$ Wielonie, wystawiony $\mathrm{w}$ imieniu Witolda i Jagiełły; LUB V $2244=$ CEV 776*. Przytoczone argumenty pozwalają stwierdzić, że Witold nie był obecny w Inowrocławiu, ponadto dowiedziawszy się o wybuchu powstania na Żmudzi, bezzwłocznie tam wyruszył; CEV 781.

313 J. Purc odnotowuje pobyt Witolda w Brześciu 13 i 22 VII 1418 r., jednak w obu miejscach przezeń wskazanych chodzi o przedłużenie rozejmu z zakonem w Brześciu Kujawskim, a nie Litewskim; natomiast data podana $\mathrm{w}$ inwentarzu archiwum koronnego z $1682 \mathrm{r}$. , ad annum a festo S. Margarethae" (Inventarium omnium et singulorum privilegiorum, litterarum, diplomatum, scripturarum et monumetorum..., wyd. E. Rykaczewski, Lutetiae Parisiorum 1862, s. 80) odnosi się nie do dokumentu, lecz terminu rozejmu (SVDO I 129).

314 Śmierć Anny Witoldowej. Została pochowana w Wilnie. Być może Witold wówczas tam przebywal.

315 List rządcy Nidzicy do komtura Ostródy, w którym donosił o epidemii na Litwie i o pobycie Witolda koło Łucka, pod datą „Gegeben czu Nidenburg am tage Assumpcionis Marie virginis”, może być datowany zarówno na 1418, jak i 1419 r.; Jóźwiak 2004, s. 124-125, 231-232.

316 Przywilej Witolda dla Teodoryka Buczackiego, zachowany jedynie w późnych regestach, ma datę: „Pyssan w Horodka Dawydowye, miessiącza augusta w rok A [?] Ao”, AGAD, ML, ks. IV B 17, k. 165v. Rok ewidentnie zniekształcony przez kopistę, pierwszy znak albo dwa odczytane przypuszczalnie. Być może dokument należy datować na 1418 r.: 8 września w Woranach Witold wystawił przywilej dla Grzegorza Szypa z Dawidowic, pierwszym na liście świadków jest kniaź Dawid Horodecki, wymieniony bez tytułu kniaziowskiego, podobnie jak kolejny świadek Michał Iwanowicz Holszański (dokument zachował się w oryginale: Vitoldiana 94). Nie wykluczam, ale uważam za mniej prawdopodobną datację zaproponowaną przez J. Kurtykę - 1424 r. 


\begin{tabular}{|c|c|c|c|c|}
\hline \multicolumn{2}{|c|}{ Data } & \multirow{2}{*}{$\begin{array}{c}\text { Miejsce } \\
\text { Kowno (plan) } \\
\end{array}$} & \multirow{2}{*}{\begin{tabular}{|l|}
\multicolumn{1}{|c}{ Źródło } \\
CEV 796
\end{tabular}} & \multirow[t]{2}{*}{ Uwagi } \\
\hline & 11 & & & \\
\hline & \multirow[t]{2}{*}{12} & $\begin{array}{l}\text { nad rzeką } \\
\text { Gege, ob. } \\
\text { Pojegi (plan) }\end{array}$ & CEV 796 & \multirow{9}{*}{$\begin{array}{l}\text { spotkanie z Jagiełłą, który } \\
\text { przybył na zjazd z kierownic- } \\
\text { twem zakonu krzyżackiego; } \\
\text { na Litwie król przebywał do } \\
\text { początku } 1419 \text { r. (Szweda } \\
\text { 2009, s. } 388-389 \text {; Gąsiorow- } \\
\text { ski } 2015 \text {, s. } 88-89 \text { ) }\end{array}$} \\
\hline & & $\begin{array}{l}\text { lub Dorsu- } \\
\text { niszki (?) }\end{array}$ & Dług. XI, s. 88 & \\
\hline & $13-21$ & Wielona & $\begin{array}{l}\text { CEV 796; BGDO II 273, } \\
285 \text { (plan); SVDO I 131; } \\
\text { SRP III, s. 376, 379; } \\
\text { Dług. XI, s. } 88\end{array}$ & \\
\hline & 22 & Kowno & CEV 800; SVDO I 131 & \\
\hline & 26 & Troki & Dług. XI, s. 88 & \\
\hline & 30 & Wilno & CEV $805^{318}$ & \\
\hline \multirow[t]{2}{*}{ XI } & 13 & Grodno & Dług. XI, s. 88 & \\
\hline & 29 & Grodno & Vitoldiana 227 & \\
\hline XII & 14 & Punia & CEV 819 & \\
\hline \multicolumn{5}{|c|}{1419} \\
\hline \multicolumn{2}{|c|}{ I i/lub II } & $\begin{array}{l}\text { Ruś, daleko od } \\
\text { Litwy właściwej }\end{array}$ & CEV 826 & \\
\hline III & 9 & Słonim & CEV 826 & \\
\hline IV & $9-16^{319}$ & Grodno (plan) & CEV 828 & \\
\hline \multicolumn{2}{|c|}{$\begin{array}{l}\text { koniec maja - } \\
\text { początek czerwca }^{320}\end{array}$} & Wilno & CEV 840 & \\
\hline VI & $\begin{array}{l}\text { druga } \\
\text { połowa - } \\
\text { koniec }\end{array}$ & Litwa & $\begin{array}{l}\text { GStAPK, OBA } \\
2978 / 79^{321}\end{array}$ & \\
\hline
\end{tabular}

317 Zachodzi sprzeczność między relacją Długosza o spotkaniu króla przez Witolda w Dorsuniszkach a listem Witolda z 9 X 1418 r. o zamiarze spotkania króla i przybycia do Kowna wieczorem 11 października. Dorsuniszki leżą nad Niemnem znacznie bardziej na północ niż Kowno, Wielona i Pojegi. Albo więc Witold bardzo szybko zmienił trasę podróży, albo informacja Długosza jest niedokładna. Gąsiorowski 2015, s. 88, przyjmuje następującą trasę podróży Jagiełły: Dorsuniszki - Kowno.

318 Rozkaz Jagiełły nakazujący szlachcie podolskiej złożenie hołdu Witoldowi nie zawiera bezpośrednich danych o miejscu pobytu tego ostatniego, ale najprawdopodobniej został wydany w jego obecności, ze względu na itineraria obu władców.

319 J. Purc odnotowuje pobyt Witolda w Gniewkowie na początku maja 1419 r., z powołaniem się na CEV 834*. W rzeczywistości pertraktowali tam nie władcy Polski, Litwy i zakonu, lecz ich pełnomocnicy; Szweda 2009, s. 389-390; Gąsiorowski 2015, s. 90.

320 Komtur Renu w liście z Kętrzyna z 11 VI 1419 r. donosił, że Witold przez 2 tygodnie przebywał w Wilnie, ale nie poinformował, kiedy wielki książę tam przybył.

${ }^{321}$ List komtura Balgi jadącego do Witolda, napisany w Kętrzynie 18 VI 1419 r. 


\begin{tabular}{|c|c|c|c|c|}
\hline \multicolumn{2}{|c|}{ Data } & Miejsce & Źródło & Uwagi \\
\hline \multicolumn{2}{|c|}{ przed 4 VII } & Wilno & LUB V 2328 & \\
\hline \multirow[t]{2}{*}{ VII } & 15 & $\begin{array}{l}\text { nad Wisłą koło } \\
\text { Czerwińska }\end{array}$ & $\begin{array}{l}\text { CEV } 845=\text { Nowak 1971, } \\
\text { s. } 65-73 ; \text { KDKW } 77\end{array}$ & \multirow{2}{*}{$\begin{array}{l}\text { spotkanie z Jagiełłą - } \\
\text { wyprawa do Prus (Gąsiorow- } \\
\text { ski } 2015, \text { s. } 90)^{322}\end{array}$} \\
\hline & 26 & Bądzyń & $\begin{array}{l}\text { KDL, s. } 248=\text { SVDO I } \\
135^{\star}=\text { CEV } 848^{\star}\end{array}$ & \\
\hline VIII & przed 15 & $\begin{array}{l}\text { koło } \\
\text { Łucka (?) }\end{array}$ & GStAPK, OBA 27929 & \\
\hline XII & & Litwa & & $\begin{array}{l}\text { spotkanie z Jagiełłą, który } \\
\text { spędził na Litwie okres od } \\
\text { końca grudnia do początku } \\
\text { lutego (Gąsiorowski 2015, } \\
\text { s. 91; CEV 855) }\end{array}$ \\
\hline \multicolumn{5}{|c|}{1420} \\
\hline \multirow[t]{3}{*}{ I } & $12-13$ & Dowgi & Dług. XI, s. 116-117 & \\
\hline & 13 & Ilgi & Dług. XI, s. 117 & \\
\hline & 27 & Ilgi & Dług. XI, s. 118 & \\
\hline \multirow[t]{5}{*}{ II } & 2 & Litwa & CEV $855^{324}$ & \\
\hline & 8 & Dubinki & CEV 857 & \\
\hline & $8 / 9-15$ & Troki (plan) & CEV 857 & \\
\hline & 12 & Troki & CEV 858 & \\
\hline & & Litwa & LUB V 2456 & \\
\hline III & 11 & Berszty & CEV 861 & \\
\hline \multirow[t]{2}{*}{ IV } & & $\begin{array}{l}\text { Kowno lub } \\
\text { Wielona }\end{array}$ & CEV 865 & \\
\hline & 6 & Troki (?) & Полехов 2018, nr $1^{325}$ & \\
\hline V & $\begin{array}{l}9 \text { i wcześ- } \\
\text { niej }\end{array}$ & Troki & GStAPK, OBA 3166 & \\
\hline VI & 9 & Nowy Dwór & $\begin{array}{l}\text { LUB V } 2277= \\
\text { CEV } 878^{\star}, 879^{* 326}\end{array}$ & \\
\hline
\end{tabular}

322 Długosz datuje spotkanie na 22 lipca; Dług. XI, s. 100.

${ }^{323}$ Źródło może być datowane zarówno na rok 1418, jak i 1419 (zob. wyżej, przyp. 315).

${ }^{324} \mathrm{~W}$ tym liście wielki mistrz prosił Witolda o przyjęcie jego posłów, wysłanych do króla polskiego do Grodna, niejasne jednak, czy przebywał tam też wielki książę litewski (miejsce pobytu obu władców zwierzchnik zakonu określił jako Litwę).

325 Bardziej prawdopodobna jest datacja dokumentu na 6 IV 1398 albo 1409 r. - zob. wskazany artykuł.

${ }^{326}$ W LUB błędnie datowano na 9 VI $1420 \mathrm{r}$. W CEV pomyłkowo odnotowano dwukrotnie - wedle edycji w LUB i odpisu w archiwum królewieckim, który stał się podstawą tej edycji (zob. RHD, nr 3180, s. 200); przy tym miejsce wystawienia określono jako Worany ze znakiem zapytania. 


\begin{tabular}{|c|c|c|c|c|}
\hline \multicolumn{2}{|c|}{ Data } & \multirow{2}{*}{\begin{tabular}{|c|} 
Miejsce \\
Nowogródek
\end{tabular}} & \multirow{2}{*}{$\frac{\text { Źródło }}{\text { ПСРЛ ХХХV, s. } 56}$} & \multirow{2}{*}{$\begin{array}{l}\text { Uwagi } \\
\text { spotkanie } \mathrm{z} \text { metropolitą } \\
\text { Focjuszem }\end{array}$} \\
\hline $\mathrm{VII}^{327}$ & & & & \\
\hline VIII & 10 & Worany & CEV 889 & \\
\hline \multirow[t]{3}{*}{ IX } & $8-11^{328}$ & Wielona & $\begin{array}{l}\text { CEV 898; SHRM } \\
115=\text { CEV } 900^{*}= \\
\text { SVDO I } 156^{*}\end{array}$ & $\begin{array}{l}\text { zjazd z wielkim mistrzem } \\
\text { krzyżackim }\end{array}$ \\
\hline & 28 & Suraż & $\begin{array}{l}\text { NGAB, f. } 1708 \text {, op. } 1 \text {, } \\
\text { s. } 23, \text { k. } 531-531 \mathrm{v}= \\
\text { CDIAUL, f. } 966 \text {, op. } 1 \text {, } \\
\text { s. } 16, \text { k. } 99 \mathrm{v}-100 \mathrm{v}\end{array}$ & \\
\hline & $30^{329}$ & Drohiczyn & $\begin{array}{l}\text { NGAB, f. 1744, op. 1, } \\
\text { s. } 13 \text {, k. } 535-535 \mathrm{v}= \\
\text { Archiwum Narodowe } \\
\text { w Krakowie, Zbiór Zyg- } \\
\text { munta Glogera, sygn. 55, } \\
\text { s. } 1114-1116\end{array}$ & \\
\hline $\mathrm{X}$ & $29-30$ & Łuck & Kurtyka. Rep. $134^{\star}, 135^{\star}$ & $\begin{array}{l}\text { spotkanie z Jagiełłą: świad- } \\
\text { kowie dokumentu Piotra } \\
\text { Szafrańca wystawionego } \\
\text { w Łucku } 19 \text { X } 1420 \text { należą do } \\
\text { otoczenia Jagiełły i Witolda; } \\
\text { na początku listopada Jagiełło } \\
\text { był już na Rusi koronnej } \\
\text { - w Medyce i Jarosławiu } \\
\text { (ZDM V 1324; Gąsiorowski } \\
\text { 2015, s. 93) }\end{array}$ \\
\hline
\end{tabular}

J. Purc odnotowuje pobyt Witolda w miejscowości „Urzow” 30 lipca, powołując się na AS I 23. Jak wykazał W. Sobczuk, dokument ten jest falsyfikatem, którego podstawę stanowił przywilej wystawiony przez Witolda we Rżewie podczas wyprawy na Nowogród w 1428 r.; В.Д. Собчук, Від коріння до крони. Дослідження з історії князівських і шляхетських родів Волині XV першої половини XVII cm., Кременець 2014, s. 387-406.

327 Metropolita Focjusz, według jego latopisu, wyjechał do WKL 1 VI 1420 r., a w Nowogródku spotkał się nie tylko z Witoldem, ale też z posłem cesarza bizantyńskiego Manuela II Paleologa, Manuelem Filantroponem. W sierpniu poselstwo greckie było już w Małopolsce; Б.Н. Флоря, op. cit., s. 348.

328 Wielki mistrz 30 V 1420 r. wystawił glejt dla Witolda do św. Michała (29 IX 1420 r.) w celu przybycia na zjazd, który miał rozpocząć się 8 września; ОР РГБ, f. 68, b. 358.7, k. 128 - odpis z niezachowanego foliantu archiwum królewieckiego: OF 11, s. 27; por. wzmiankę o podróży wielkiego mistrza na ten zjazd w liście do Witolda z 1 IX 1420 r.; GStAPK, OBA 3246.

329 W odpisach dokument ma datę ewidentnie zniekształconą: „Actum et datum in castro nostro Drohiciensi, feria secunda die sancti Sedimini, milesimo quadringentesimo vicesimo”. Imię niestniejącego świętego „Sedimini” można interpretować jako zniekształcone „Jeronimi/Hieronimi” lub „Sergii martiris”. Opowiadam się za pierwszą opcją, ponieważ św. Sergiusz raczej nie zostałby tu wspomniany bez św. Bakchusa. 


\begin{tabular}{|c|c|c|c|c|}
\hline \multicolumn{2}{|c|}{ Data } & Miejsce & Źródło & Uwagi \\
\hline \multirow[t]{2}{*}{ XI } & 8 & Łuck & Vitoldiana 185 & \\
\hline & & Litwa (?) & Dług. XI, s. $140^{330}$ & \\
\hline XII & & Troki (?) & & $\begin{array}{l}\text { spotkanie z Jagiełłą w końcu } \\
\text { grudnia } 1420 \text { - początku } \\
\text { lutego (Gąsiorowski 2015, } \\
\text { s. 93-94) }\end{array}$ \\
\hline \multicolumn{5}{|c|}{1421} \\
\hline II & $2-7$ & Worany ${ }^{331}$ & Dług. XI, s. $144-145$ & \\
\hline \multirow[t]{3}{*}{ VI } & po 20 & Wilno & LUB V 2553 & \\
\hline & 22 & Troki $^{332}$ & KDKW 78 = CM I 29 & \\
\hline & $\begin{array}{l}\text { po } 24 \\
\text { (może } \\
\text { początek } \\
\text { lipca) }\end{array}$ & Krzemieniec $^{333}$ & $\begin{array}{l}\text { Klimas 1933, s. 139, } \\
\text { 154-156; Кудрявцев } \\
\text { 2003, s. 79, §84 }\end{array}$ & \\
\hline VII & 25 & Dubicze & $\begin{array}{l}\text { CEV 956, 957*; } \\
\text { SVDO I } 149\end{array}$ & \\
\hline \multirow[t]{3}{*}{ VIII } & 9 & Troki & CM I $30=$ KDKW $78 b^{334}$ & \\
\hline & $\begin{array}{l}\text { między } 9 \\
\text { a } 15\end{array}$ & Brześć (plan) & LUB V $2560=$ CEV $962^{*}$ & \\
\hline & 15 & Lublin $^{335}$ & Dług. XI, s. 147 & $\begin{array}{l}\text { spotkanie z Jagiełłą } \\
\text { (Gąsiorowski 2015, s. 94) }\end{array}$ \\
\hline
\end{tabular}

${ }^{330}$ Według informacji Długosza po odesłaniu części posłów czeskich do Witolda Jagiełło zabrał pozostałych ze sobą do Niepołomic. Tam jego pobyt poświadczony jest w listopadzie $1420 \mathrm{r}$.; Gąsiorowski 2015, s. 93.

331 Według J. Purca Witold przebywał nad Narwią 16 lutego i w Krakowie 8 IV 1421 r. Jednak w pierwszym przypadku badacz powołuje się na dokument Jagiełły, w którym nic nie wskazuje na Witolda; CESXV I 54. Jego jednoczesna obecność w tym samym miejscu państwa litewskiego jest prawdopodobna, ale niekonieczna. Natomiast $\mathrm{w}$ drugim przypadku mamy do czynienia z układem polsko-litewsko-brandenburskim wystawionym przez Jagiełłę w imieniu Witolda; Codex diplomaticus Brandenburgensis, cz. 2, t. 3, wyd. A.F. Riedel, Berlin 1846, nr 1394, s. $399-401=$ SVDO I 147.

332 Wbrew wskazówce J. Purca, w Oziminie 24 VI 1421 r. Ghillebert de Lannoy zastał jedynie Władysława Jagiełłę, natomiast Witolda tam nie było; SRP III, s. 450-452; Gąsiorowski 2015, s. 94.

333 Ghillebert de Lannoy mówi o przyjęciu u Witolda w mieście „Kamenich”, ale skoro wyjeżdża stąd przez Lwów i „Górną Ruś” do „innego Kamieńca” położonego na Podolu, to jasne, że chodzi o Krzemieniec, co już nie raz odnotowano w literaturze.

${ }^{334} \mathrm{~W}$ KDKW podano tylko datę roczną.

335 J. Purc odnotowuje pobyt Witolda w miejscowości „Urzow” 21 sierpnia, powołując się na AS I 23. Jak wykazał W. Sobczuk, dokument ten jest falsyfikatem, przy sporządzeniu którego wykorzystano autentyczny dokument wydany przez Witolda w Rżewie podczas wyprawy na Nowogród Wielki w 1428 r.; В.Д. Собчук, op. cit., s. 387-406. 


\begin{tabular}{|c|c|c|c|c|}
\hline \multicolumn{2}{|c|}{ Data } & Miejsce & Źródło & Uwagi \\
\hline \multirow[t]{2}{*}{ IX } & 18 & Troki & CEV 971 & \\
\hline & 22 & Troki & CEV 969 & \\
\hline $\mathrm{X}$ & & Litwa (?) & Dług. XI, s. 152 & \\
\hline $\mathrm{XI}$ & 1 & Nowogródek & CEV $978^{336}$ & \\
\hline XII & 31 & Wilno & CEV 982 = LUB V 2576 & $\begin{array}{l}\text { spotkanie z Jagiełłą poświad- } \\
\text { czonym w WKL w końcu } \\
\text { grudnia } 1421 \text { - marcu } 1422 \text { r. } \\
\text { (Gąsiorowski 2015, s. 95-96) }\end{array}$ \\
\hline \multicolumn{5}{|c|}{1422} \\
\hline I & 5 & Wilno & SHRM 216 = CEV 983* & \\
\hline \multirow[t]{2}{*}{ II } & ok. $22-25$ & $\begin{array}{l}\text { Nowogródek } \\
(?)^{337}\end{array}$ & Dług. XI, s. $157-158$ & \\
\hline & 27 & Lida & Dług. XI, s. 158 & \\
\hline III & 5 & Troki & CEV 995 & \\
\hline IV & 1 & Brześć $c^{338}$ & CEV 1023 & \\
\hline $\mathrm{V}$ & 25 & Rudomino & CEV 1010 & \\
\hline \multirow[t]{2}{*}{ VI } & 2 & Wilno & CEV 1012 & \\
\hline & $\begin{array}{l}26 \text { i wcześ- } \\
\text { niej }\end{array}$ & $\begin{array}{l}\text { Bielsk Podla- } \\
\text { ski }^{339}\end{array}$ & CEV 1025 & \\
\hline VII & 10 & Drohiczyn $^{340}$ & CEV, dod. 42, s. 1067 & \\
\hline
\end{tabular}

336 J. Purc odnotowuje pobyt Witolda w Nowogródku 8 XI 1421 r., jednak list, na który się powołuje, nie ma daty rocznej i może być datowany na koniec pierwszej dekady XV w.; ПГ I 29; ПГ II, s. 46-47 (kom. S.P.).

337 Ślub Jagiełły z Zofią Holszańską (o jego dacie zob. Gąsiorowski 2015, s. 95). Ze względu na informację Długosza o inicjatywie Witolda bardzo prawdopodobny wydaje się jego pobyt na uroczystościach ślubnych. J. Purc odnotowuje pobyt Witolda w Niepołomicach, ale odpowiedni fragment u Długosza dotyczy nie Witolda, lecz doradców królewskich, którzy próbowali skłonić władcę do rezygnacji ze ślubu z Zofią.

338 J. Purc odnotowuje pobyt Witolda w Grodnie 9 IV 1422 r., powołując się na: М.К. Любавский, Литовско-русский сейм. Опыт по истории учреждения в связи с внутренним строем и внешнею жизнью государства, Москва 1900, s. 321. Jednak ten przywołuje dokument (LM XXV, nr 237), który ma datę 20 IV 1424 r. (zob. niżej).

33923 VI 1422 r. komtur Człuchowa informował wielkiego mistrza, że Witold jeszcze nie przeprawił się przez Wisłę (GStAPK, OBA $3779=$ CEV 1021*, w streszczeniu ta informacja pominięta), natomiast 29 VI 1422 r. wójt Nowej Marchii donosił, że Jagiełło jeszcze nie spotkał się z Witoldem (GStAPK, OBA 3788).

340 Według danych rządcy Nidzicy, które przekazał wielkiemu mistrzowi komtur Ostródy, Witold zamierzał przeprawiać się przez Wisłę w Pułtusku oddzielnie od Jagiełły 7 lipca (GStAPK, OBA 3803), później termin został odroczony do 11 lipca (GStAPK, OBA 3809). Chłopi, którzy byli w Płocku z rozkazu wójta Działdowa 6 lipca, donieśli, że Witold opuścił Drohiczyn tego samego dnia (GStAPK, OBA 3809). Zapewne chodziło o działania różnych oddziałów wojska. 


\begin{tabular}{|c|c|c|c|c|}
\hline \multicolumn{2}{|c|}{ Data } & \multirow{2}{*}{$\begin{array}{r}\text { Miejsce } \\
\begin{array}{l}\text { Pułtusk } \\
(\text { plan})^{341}\end{array} \\
\end{array}$} & \multirow{2}{*}{\begin{tabular}{|r|} 
Źródło \\
CEV 1025
\end{tabular}} & \multirow[t]{2}{*}{ Uwagi } \\
\hline & $\begin{array}{l}\text { między } \\
10 \text { a } 26\end{array}$ & & & \\
\hline & 21 & nad Narwią & GStAPK, OBA 3825 & \\
\hline & 26 & Czerwińsk & $\begin{array}{l}\text { Dług. XI, s. } 169 \text {; por. } \\
\text { SRP III, s. } 488\end{array}$ & \\
\hline & 30 & $\begin{array}{l}\text { Lidzbark } \\
\text { (Welski) }^{342}\end{array}$ & Dług. XI, s. 169 & \\
\hline \multirow[t]{7}{*}{ VIII } & $2-6$ lub 7 & pod Lubawą & $\begin{array}{l}\text { GStAPK, OBA } 3858 \text {, } \\
3859,3862 \text {; Dług. XI, } \\
\text { s. } 169-171 \text {; SRP III, } \\
\text { s. } 630\end{array}$ & \multirow{8}{*}{$\begin{array}{l}\text { wojna Polski i Litwy } \\
\text { z zakonem krzyżackim }\end{array}$} \\
\hline & $7^{343}$ & $\begin{array}{l}\text { koło Bratianu } \\
\text { nad Drwęcą }\end{array}$ & CEV 1036 & \\
\hline & $9-11$ & Prabuty & $\begin{array}{l}\text { Dług. XI, s. 171; } \\
\text { GStAPK, OBA } 3874\end{array}$ & \\
\hline & $11-13$ & nad rzeką Ossą & Dług. XI, s. 172 & \\
\hline & 13 & Biskupiec & CEV 1037 & \\
\hline & & $\begin{array}{l}\text { nad Jeziorem } \\
\text { Wądzyńskim } \\
\text { (an dem sehe } \\
\text { Wansen) }\end{array}$ & $\begin{array}{l}\text { GStAPK, OBA } 3872 \text {; } \\
\text { Dług. XI, s. 172-173 }\end{array}$ & \\
\hline & $16-23$ & pod Golubiem & $\begin{array}{l}\text { CEV 1038; GStAPK, } \\
\text { OBA } 3872,3890 ; \\
\text { Dług. XI, s. } 173-174 ; \\
\text { SRP III, s. } 630\end{array}$ & \\
\hline \multicolumn{2}{|c|}{25 VIII-5 IX ${ }^{344}$} & $\begin{array}{l}\text { Kowalewo } \\
\text { Pomorskie }\end{array}$ & $\begin{array}{l}\text { Dług. XI, s. 179-180; } \\
\text { GStAPK, OBA 3900, } \\
\text { 3912; SRP III, s. } 630\end{array}$ & \\
\hline
\end{tabular}

34119 VII 1422 r. wójt Bratianu donosił wielkiemu mistrzowi, że według informacji z poprzedniego dnia wojsko królewskie i książę Witold ze swoimi ludźmi znajduje się w odległości 3 mil na południe od Płońska albo Płocka („III myle jenehalbe Pluntzk”). Ta lokalizacja nie odpowiada trasie przemarszu Witolda, znajduje się bowiem na zachód od Narwi i Czerwińska. Może chodziło o działania różnych oddziałów wojska.

${ }^{342}$ Itinerarium Witolda w czasie wojny w 1422 r., gdy nie ma bezpośrednich wskazówek dotyczących miejsca jego pobytu, jest rekonstruowane na podstawie itinerarium Jagiełły, poświadczonego w źródłach znacznie dokładniej. Jest to jednak nieco umowne, np. choć Długosz kilkakrotnie wspomina o wspólnych działaniach Witolda i Jagiełły (Dług. XI, s. 172, 174-177, 180-181), to $\mathrm{z}$ listu Witolda wynika, że przybył on pod Bratian co najmniej o jeden dzień wcześniej niż Jagiełło (zob. następny przypis).

${ }^{343}$ Jagiełło przesunął się z Lubawy do Bratianu dopiero 8 VIII 1422 r.; Gąsiorowski 2015, s. 97.

34410 IX 1422 r. wielki marszałek informował wielkiego mistrza o odejściu przeciwnika od Kowalewa o północy z 5 na 6 września (GStAPK, OBA 3914), podczas gdy z narracji Długosza wynika, 


\begin{tabular}{|c|c|c|c|c|}
\hline \multicolumn{2}{|c|}{ Data } & \multirow{2}{*}{\begin{tabular}{|c|} 
Miejsce \\
koło Lubicza
\end{tabular}} & \multirow{2}{*}{\begin{tabular}{|l|}
\multicolumn{1}{c|}{ Źródło } \\
Dług. XI, s. 181; \\
GStAPK, OBA 3914
\end{tabular}} & Uwagi \\
\hline \multirow[t]{10}{*}{ IX } & 6-ok. 9 & & & \\
\hline & ok. 9 & $\begin{array}{l}\text { Papowo } \\
\text { Biskupie }\end{array}$ & Dług. XI, s. 180-181 & \\
\hline & ok. 9-14 & koło Chełmna & $\begin{array}{l}\text { Dług. XI, s. 181; } \\
\text { GStAPK, OBA } 3917\end{array}$ & \\
\hline & 15 & Robakowo & GStAPK, OBA 3917 & \\
\hline & 16 & Turznice & GStAPK, OBA 3919 & \\
\hline & 17 & $\begin{array}{l}\text { między } \\
\text { Okoninem } \\
\text { a Pokrzywnem } \\
\end{array}$ & GStAPK, OBA 3920 & \\
\hline & 25 & $\begin{array}{l}\text { nad Jeziorem } \\
\text { Mełneńskim }\end{array}$ & MRPS IV 7887* & \\
\hline & 26 & $\begin{array}{l}\text { nad Jeziorem } \\
\text { Mełneńskim }\end{array}$ & GStAPK, OBA 3928 & \\
\hline & 27 & $\begin{array}{l}\text { nad Jeziorem } \\
\text { Mełneńskim }\end{array}$ & Dokumenty 2004 & \\
\hline & 29 & koło Rypina ${ }^{345}$ & $\begin{array}{l}\text { Vitoldiana } 98=\text { Kurtyka. } \\
\text { Rep. } 156^{*}\end{array}$ & \\
\hline $\mathrm{XI}$ & 29 & Berszty (Berzsch) & CEV $1051^{346}$ & \\
\hline \multirow[t]{2}{*}{ XII } & 28 & Troki & Dług. XI, s. 187 & $\begin{array}{l}\text { spotkanie z Jagiełłą poświad- } \\
\text { czonym w WKL w końcu } \\
1422 \text { - styczniu } 1423 \text { r. } \\
\text { (Gąsiorowski } 2015, \text { s. } 98 \text { ) }\end{array}$ \\
\hline & 30 & Troki & CEV 1055 & \\
\hline \multicolumn{5}{|c|}{1423} \\
\hline II & 12 & Litwa $^{347}$ & $\begin{array}{l}\text { LUB V 2681, 2701; } \\
\text { GStAPK, OBA } 4075\end{array}$ & \\
\hline
\end{tabular}

że nastąpiło to 2 września, a od Kowalewa wojska skierowały się do Papowa. Zob. krytykę takiego przedstawienia trasy marszu wojsk w: S. Ekdahl, Der Krieg zwischen dem Deutschen Orden und Polen-Litauen im Jahre 1422, „Zeitschrift für Ostforschung” 13, 1964, nr 4, s. 625-626; Biskup 1993, s. 136-137.

345 J. Purc odnotowuje podróż Witolda w stronę Przemyśla późną jesienią 1422 r., powołując się na: E. Maleczyńska, Rola polityczna królowej Zofii Holszańskiej na tle walki stronnictw w Polsce w latach 1422-1434, Lwów 1936, s. 41. Jednak w przywołanej przez nią relacji Kroniki Bychowca (ПСРЛ ХVII, s. 523) widać reminiscencje unii horodelskiej 1413 r., aczkolwiek jej warunki są łączone z czwartym małżeństwem Jagiełły. Horodło leży ok. 180 km od Przemyśla. U Długosza we wskazanym przez E. Maleczyńską miejscu (Dług. XI, s. 177-178) jest mowa o działaniach wojennych w 1422 r. Późną jesienią 1422 r. Jagiełło nie był na Rusi; Gąsiorowski 2015, s. 97-98.

${ }^{346}$ W nagłówku w CEV jako miejsce wystawienia listu błędnie podano Birże.

347 Wbrew wskazówce J. Purca, w liście wielkiego mistrza krzyżackiego do mistrza inflanckiego z 12 II 1423 r. jest mowa nie o pobycie Witolda w Wielonie, lecz o uzgodnieniu zjazdu ze 


\begin{tabular}{|c|c|c|c|c|}
\hline \multicolumn{2}{|c|}{ Data } & \multirow{2}{*}{$\begin{array}{r}\text { Miejsce } \\
\text { Smoleńsk }^{348}\end{array}$} & \multirow{2}{*}{\begin{tabular}{l}
\multicolumn{1}{c}{ Źródło } \\
ПСРЛ XVIII, s. 167; \\
ДДГ 22
\end{tabular}} & \multirow{2}{*}{\begin{tabular}{|l}
\multicolumn{1}{|c}{ Uwagi } \\
spotkanie z wielką księżną \\
moskiewską Zofią Witol- \\
dówną i jej synem Wasy- \\
lem (II), zatwierdzenie testa- \\
mentu Wasyla I
\end{tabular}} \\
\hline III & & & & \\
\hline IV & 26 & Troki & CEV 1079 & \\
\hline \multirow[t]{2}{*}{ V } & $9-18$ & Wielona & $\begin{array}{l}\text { Dług. XI, s. 191; } \\
\text { CEV 1083, 1084, 1095; } \\
\text { SVDO I 155 } \\
\text { GStAPK, OBA 4075, } 4093\end{array}$ & $\begin{array}{l}\text { zjazd Witolda, dostojników } \\
\text { polskich i litewskich z wiel- } \\
\text { kim mistrzem krzyżackim } \\
\text { (Szweda 2009, s. 393-394). } \\
\end{array}$ \\
\hline & po 18 & Troki & Dług. XI, s. 191 & \\
\hline VIII & 27 & Worany & $\begin{array}{l}\text { Jablonskis } 1933 \text {, s. } 405= \\
\text { KDKW } 86=\text { Vitoldiana } \\
35^{349}\end{array}$ & \\
\hline $\mathrm{X}$ & 15 & Troki & CEV 1109 & \\
\hline
\end{tabular}

zwierzchnikami zakonnymi w tym mieście. Chronologia poselstwa krzyżackiego do Witolda wskazuje, że znajdował się wówczas na Litwie.

${ }^{348}$ Niekiedy można się spotkać ze stwierdzeniem, że Witold był obecny na zjeździe Zygmunta Luksemburskiego z Jagiełłą w Kieżmarku 30 III 1423 r. (zob. np. R. Petrauskas, Lietuvos Didžioji Kunigaikštystè ir universalus Romos, Vengrijos bei Čekijos karaliaus Zigmanto Liuksemburgo pasaulis, w: E. Windecke, Imperatoriaus Zigmanto knyga: XV a. Lietuvos valdovu portretai. Pasakojimai ir vaizdai, red. J. Kiaupienė, R. Petrauskas, Vilnius 2015, s. 13), ponieważ do egzemplarza zawartego tam układu polsko-litewskiego z Zygmuntem została przywieszona też pieczęć Witolda (oryginał w Haus-, Hof- und Staatsarchiv w Wiedniu pod datą; edycje z odpisów: KDL, s. 300-303; LC I 120). Jeszcze pod koniec 1422 r. zakładano, że Jagiełło przybędzie na zjazd z królem rzymskim razem z Witoldem, por. wskazówkę w dokumencie biskupa krakowskiego Wojciecha Jastrzębca o ustaleniu daty i miejsca zjazdu z 12 XII 1422 r.; GStAPK, OBA 3999; zob. też Dług. XI, s. 185. Już w połowie lutego Witold dał poselstwu krzyżackiemu do zrozumienia, że nie pojedzie do Kieżmarku; LUB V 2701; zob. też KDL, s. 299-300 = CEV $1065=$ GStAPK, OBA 4059. Przyczyną była nie tylko - a może nie tyle - choroba Witolda (LC II 122, 123), ile potrzeba zatwierdzenia testamentu jego zięcia Wasyla I, którego realizacji po śmierci tegoż mógł przeszkadzać jego brat Jurij Dymitrowicz, inny pretendent do tronu moskiewskiego. Do testamentu została przywieszona pieczęć Witolda; zob. С.В. Полехов, Последние завещания Василия I и печати Витовта, „Средневековая Русь” 12, 2016. W początkach i w połowie kwietnia Witold przebywał na Litwie, gdzie podążał do niego przez Małopolskę poseł Zygmunta Korybutowicza (Krzyżanowski, s. 422); w tym samym czasie do Witolda pisal wielki mistrz z zapytaniem, czy otrzymał on już listy wielkiego marszałka zakonu, który był na zjeździe króla polskiego z Zygmuntem Luksemburskim na Węgrzech i wysłał te listy przez Polskę i Litwę. W tym samym liście uczestnikami zjazdu nazwano „die beiden koninge mit den iren und iren beilegern"; GStAPK, OBA 4093. W świetle tego wydaje się, że informacje o udziale Witolda w zjeździe z Zygmuntem w Kieżmarku podane przez współczesnych kronikarzy Eberharda Windeckego i Andrzeja z Ratyzbony są efektem pomyłki.

349 W edycji J. Ochmańskiego miejsce wystawienia dokumentu z niejasnych przyczyn określono jako „Wor[n]any”, choć w oryginale wyraźnie „Worany”. 


\begin{tabular}{|c|c|c|c|c|}
\hline \multicolumn{2}{|c|}{ Data } & \multirow{2}{*}{$\begin{array}{l}\text { Miejsce } \\
\text { Litwa (?) }\end{array}$} & \multirow{2}{*}{\begin{tabular}{|l|}
\multicolumn{1}{c}{ Źródło } \\
LUB VII $54^{350}$ \\
\end{tabular}} & \multirow[t]{2}{*}{ Uwagi } \\
\hline XI & & & & \\
\hline XII & 25 & Troki & $\begin{array}{l}\text { LUB VII 54; por. } \\
\text { CEV } 1175^{351}\end{array}$ & $\begin{array}{l}\text { spotkanie z Jagiełłą poświad- } \\
\text { czonym w WKL w końcu } \\
\text { grudnia } 1423 \text { - początkach } \\
\text { stycznia } 1424 \text { r. (Gąsiorowski } \\
2015 \text {, s. } 100-101 \text { ) }\end{array}$ \\
\hline \multicolumn{5}{|c|}{1424} \\
\hline \multirow[t]{2}{*}{ I } & początek & Worany & $\operatorname{CEV} 1124^{*}$ & \\
\hline & 6 & Wilno (?) & LUB VII $66^{\star}, 71$ & \\
\hline III & & Litwa $^{353}$ & $\begin{array}{l}\text { Dług. XI, s. 198-199; } \\
\text { Krzyżanowski, s. } 427\end{array}$ & \\
\hline \multirow[t]{5}{*}{ IV } & 5 & Berszty (? $)^{354}$ & $\begin{array}{l}\text { Мікульскі 2014, nr 1, } \\
\text { s. } 128=\text { Мицик } 2018 \text {, } \\
\text { s. } 8\end{array}$ & \\
\hline & 16 & Grodno & CEV 1139 & \\
\hline & $19-20$ & Grodno 355 & $\begin{array}{l}\text { Dług. XI, s. 200-201; } \\
\text { Vitoldiana 100, 101; } \\
\text { LM XXV, nr 237; } \\
\text { Jarmolik 1990, s. } 83-84 \\
\end{array}$ & \\
\hline & 24 & Grodno & CEV 1140 & \\
\hline & $25-26$ & Przełom & CEV 1141, 1142 & \\
\hline \multicolumn{2}{|c|}{ między $26 \mathrm{IV}$ a $8 \mathrm{~V}$} & $\begin{array}{l}\text { Żmudź } \\
(\text { plan })^{356}\end{array}$ & Tęgowski 2001, s. 95 & \\
\hline $\mathrm{V}$ & 8 & Kowno & CEV 1150 & \\
\hline
\end{tabular}

3503 XII 1423 r. wielki mistrz krzyżacki pisał do mistrza inflanckiego o powrocie swoich posłów wysłanych do Witolda.

351 J. Purc mylnie datuje ten dokument na koniec $1424 \mathrm{r}$.

3526 I 1424 r. w Wilnie miała się odbyć wymiana opieczętowanych dokumentów „wieczystego pokoju" pomiędzy stroną litewską a inflancką - najprawdopodobniej w obecności Witolda. W tym samym czasie na Litwie jako poseł przebywał wielki marszałek zakonu.

${ }^{353}$ Na koronacji Zofii Holszańskiej, która odbyła się 5 III 1424 r., Witold nie był obecny; Dług. XI, s. 194-195; B. Czwojdrak, Zofia Holszańska. Studium o dworze i roli królowej w późnośredniowiecznej Polsce, Warszawa 2012, s. 25.

354 Możliwa też datacja dokumentu na $1409 \mathrm{r}$.

355 Na te dni trzeba datować CEV 1133 - zapis poselstwa królów Władysława Jagiełły, Zygmunta Luksemburskiego i Eryka Duńskiego do Witolda. W CEV z niejasnej przyczyny datowano na 4 IV $1424 \mathrm{r}$.

356 W liście do margrabiego brandenburskiego Fryderyka z 23 IV 1424 r. wojewoda poznański Sędziwoj z Ostroroga wspomina o zamiarze Witolda udania się „sub partes Smodenorum”, co oznacza nie ziemię smoleńską, jak sugerował wydawca listu, lecz Żmudź; por. oryg. listu: Staatsarchiv Bamberg, Markgraftum Brandenburg-Bayreuth, Geheimes Hausarchiv Plassenburg, Akten und Bände, Nr. 4430/1. 


\begin{tabular}{|c|c|c|c|c|}
\hline \multicolumn{2}{|c|}{ Data } & \multirow{2}{*}{\begin{tabular}{|l|} 
Miejsce \\
Wilno
\end{tabular}} & \multirow{2}{*}{\begin{tabular}{|r|} 
Źródło \\
CEV 1159 \\
\end{tabular}} & \multirow[t]{2}{*}{ Uwagi } \\
\hline VI & 22 & & & \\
\hline \multirow[t]{2}{*}{ VIII } & & Dawidgródek (?) & Kurtyka. Rep. $165^{\star 357}$ & \\
\hline & 22 & Jałtuszków ${ }^{358}$ & $\begin{array}{l}\text { Vitoldiana } 102 \\
=\text { Kurtyka. Rep. } 164^{*}\end{array}$ & \\
\hline \multirow[t]{3}{*}{ IX } & 2 & Skała & $\begin{array}{l}\text { Vitoldiana } 104,106 \\
=\text { Kurtyka. Rep. } 167^{\star} \\
168^{\star}\end{array}$ & \\
\hline & $\begin{array}{l}\text { między } \\
2 \text { a } 27^{359}\end{array}$ & Krzemieniec & ПЛ II, s. 39-40 & \\
\hline & 27 & Łuck & $\begin{array}{l}\text { CEV } 1155 \text { (plan); } \\
\text { AGAD, ML, ks. IV B 9, } \\
\text { k. } 256 \text { = CDIAUL, f. } 14 \text {, } \\
\text { op. } 1, \text { kn. } 108, \text { k. } 1347\end{array}$ & $\begin{array}{l}\text { spotkanie z Jagiełłą poświad- } \\
\text { czonym w Łucku 27-29 IX } \\
1424 \text { r. (Gąsiorowski } 2015, \\
\text { s. } 103 \text { ). W tym samym czasie } \\
\text { komtur Torunia z rozkazu } \\
\text { wielkiego mistrza wysłał do } \\
\text { Łucka dwóch szpiegów, by } \\
\text { dowiedzieć się o sytuacji } \\
\text { (GStAPK, OBA 27935; o dacie } \\
\text { zob. Jóźwiak 2004, s. 70) }\end{array}$ \\
\hline \multirow[t]{2}{*}{$\mathrm{X}-\mathrm{XI}$} & & $\begin{array}{l}\text { Drohiczyn } \\
\text { (plan) }\end{array}$ & CEV 1159 & \\
\hline & & Brześć (plan) & CEV 1159 & \\
\hline \multirow[t]{3}{*}{ XII } & 2 & Grodno & GStAPK, OBA 4359 & \\
\hline & 25 & Troki (plan) & GStAPK, OBA 4359 & $\begin{array}{l}\text { spotkanie z Jagiełłą poświad- } \\
\text { czonym w WKL w końcu } \\
\text { grudnia } 1424 \text { r. (Gąsiorowski } \\
\text { 2015, s. 103). }\end{array}$ \\
\hline & koniec & Worany & $\begin{array}{l}\text { LUB VII 226, 227; } \\
\text { LC I 57; LC II } 105\end{array}$ & \\
\hline \multicolumn{5}{|c|}{1425} \\
\hline \multirow[t]{3}{*}{ I } & 1 & Worany & CEV 1181 & \\
\hline & 6 & Wilno (plan) & GStAPK, OBA 4359 & \\
\hline & & Litwa (plan) & GStAPK, OBA 4376 & \\
\hline IV & po 9 & Litwa (plan) & CEV 1191 & \\
\hline
\end{tabular}

357 Datacja zaproponowana przez J. Kurtykę; bardziej prawdopodobny wydaje się 1418 r. (zob. wyżej, przyp. 313).

35822 VIII $1424 \mathrm{r}$. Witold zamierzał być w Łucku; CEV 1159. Jak wynika z itinerarium, faktycznie pojawił się tam dopiero we wrześniu.

359 J. Purc za A. Prochaską mylnie datuje wizytę posłów pskowskich w Krzemieńcu u Witolda na listopad $1423 \mathrm{r}$. 


\begin{tabular}{|c|c|c|c|c|}
\hline \multicolumn{2}{|c|}{ Data } & Miejsce & Źródło & Uwagi \\
\hline \multirow[t]{2}{*}{ VII } & 9 & Mielnik & CEV 1197 & \\
\hline & koniec & Podlasie & $\begin{array}{l}\text { Wiśniewski 1977, } \\
\text { s. 12; Szybkowski 1999, } \\
\text { s. 293-294 }\end{array}$ & $\begin{array}{l}\text { wyprawa Witolda przeciwko } \\
\text { księciu mazowieckiemu Janu- } \\
\text { szowi Starszemu, przyłączenie } \\
\text { Tykocina i Łopuchowa do } \\
\text { WKL }\end{array}$ \\
\hline \multicolumn{2}{|c|}{ między 9 VII a 1 IX } & Ruś (plan) & CEV 1197 & \\
\hline VIII & 27 & Nowogródek & $\begin{array}{l}\text { LMAVB RS, F 15-73, } \\
\text { s. } 210\end{array}$ & \\
\hline \multirow[t]{2}{*}{ IX } & 1 & koło Trok & CEV 1197 & \\
\hline & 12 & Merecz & CEV 1204 & \\
\hline \multirow[t]{3}{*}{$\mathrm{X}$} & 12 & Nowogródek & CEV 1206 & \\
\hline & 15 & Nowogródek & CEV $1206^{360}$ & \\
\hline & 19 & Grodno & CEV 1207 & \\
\hline XI & 11 & Brześć & $\begin{array}{l}\text { CEV } 1207 \text { (plan); } \\
\text { Dług. XI, s. } 213\end{array}$ & \\
\hline \multirow[t]{5}{*}{ XII } & do 6 & $\begin{array}{l}\text { Grodno } \\
(\text { plan })^{361}\end{array}$ & CEV 1206 & $\begin{array}{l}\text { spotkanie z Jagiełłą poświad- } \\
\text { czonym w Brześciu 11-15 XI, } \\
\text { w Grodnie i na Litwie - } \\
\text { w grudniu } 1425 \text { - początkach } \\
\text { lutego } 1426 \text { r. (Gąsiorowski } \\
2015, \text { s. } 106 \text { ) }\end{array}$ \\
\hline & 8 & koło Grodna & Dług. XI, s. 214 & \\
\hline & $13-17$ & Grodno & CEV $1209^{*}$ & $\begin{array}{l}\text { zjazd Witolda, Jagiełły } \\
\text { i ich dostojników z wiel- } \\
\text { kim mistrzem krzyżackim } \\
\text { (Szweda 2009, s. 398-399) }\end{array}$ \\
\hline & $\begin{array}{l}\text { między } 17 \\
\text { i } 31(?)^{362}\end{array}$ & Jeleni Dwór & CEV 1229 & \\
\hline & 31 & Troki & Vitoldiana 187 & \\
\hline
\end{tabular}

${ }^{360}$ Brak dokładnych danych o pobycie Witolda i Jagiełły pod koniec 1425 r. w Goniądzu, gdzie proponował zjazd wielki mistrz; por. Tęgowski 2006, s. 73.

361 Według Długosza Witold i Jagiełło z Brześcia udali się na Litwę, a potem mieli „ukrywać się w lasach" przed zarazą; Dług. XI, s. 214.

362 D. Wróbel, op. cit., s. 427, datuje wyjazd wojewody poznańskiego Sędziwoja Ostroroga z Jeleniego Dworu od Witolda i Jagiełły na zjazd szlachty do Piotrkowa na koniec stycznia 1426 r. Jednak Witold mniej więcej w tym czasie przebywał koło Grodna lub na Litwie właściwej, jak można wnosić z późniejszych wzmianek i sformułowania: „ibidem in Grodno, et demum in Gelenydwor". Zwraca uwagę także to, że jako miejsce zjazdu wskazano tu Piotrków, a nie Wartę, gdzie taki zjazd rzeczywiście odbył się w lutym-marcu 1426 r.; ibidem, s. 427-428. Zapewne przed tym terminem miejsce spotkania zostało przesunięte o ok. $90 \mathrm{~km}$ na południowy wschód. 


\begin{tabular}{|c|c|c|c|c|}
\hline \multicolumn{2}{|c|}{ Data } & Miejsce & Źródło & Uwagi \\
\hline \multicolumn{5}{|c|}{1426} \\
\hline \multirow[t]{3}{*}{$\mathrm{I}$} & 6 & Mińsk & CEV 1212 & \\
\hline & 13 & Obolce & CEV 1213 & \\
\hline & 25 & Witebsk & CEV 1214 & \\
\hline \multirow[t]{4}{*}{ II } & 12 & Brasław & CEV 1214 (plan), 1216 & \\
\hline & 19 & $\begin{array}{l}\text { koło Wilna } \\
\text { (plan) }\end{array}$ & CEV 1214 & \\
\hline & 21 & Dubicze & Vitoldiana $86^{363}$ & \\
\hline & 26 & Dubicze & CEV 1216 & \\
\hline \multirow[t]{2}{*}{ III } & 10 & $\begin{array}{l}6 \text { lub } 7 \text { mil od } \\
\text { Grodna (plan) }\end{array}$ & CEV $1214^{364}$ & \\
\hline & 31 & Grodno (plan) & CEV 1214 & \\
\hline \multirow[t]{7}{*}{$\mathrm{V}$} & 3 & Wilkija & CEV 1224 & \\
\hline & 7 & Jurbork (plan) & CEV 1224 & \\
\hline & 9 & Kowno (plan) & CEV 1224 & \\
\hline & & Troki (plan) & CEV 1224 & \\
\hline & 25 & Stare Troki & CEV 1228 & \\
\hline & 30 & $\begin{array}{l}\text { Nowy Dwór, } \\
1 \text { milę od Trok } \\
\end{array}$ & CEV 1229 & \\
\hline & 31 & Troki & CEV 1229 & \\
\hline \multirow[t]{4}{*}{ VI } & $1-3$ & Troki & $\begin{array}{l}\text { CEV } 1229 \text { (plan); } \\
\text { Dług. XI, s. 218-219 }\end{array}$ & \\
\hline & \begin{tabular}{|l} 
między \\
3 i 9 \\
\end{tabular} & Wilno & Dług. XI, s. 218-219 & \\
\hline & 9 & Troki & CEV 1230 & \\
\hline & 27 & Troki & CEV $1234^{365}$ & \\
\hline \multirow[t]{2}{*}{ VII } & 9 & Miedniki & CEV 1236 & \\
\hline & $20-24$ & Połock & $\begin{array}{l}\text { CEV 1231, 1233, 1234, } \\
1236\end{array}$ & \\
\hline VIII & $1-3$ & Opoczka & $\begin{array}{l}\text { ПЛ I, s. 35-36; ПЛ ІІ, } \\
\text { s. 40, 121-124; zob. też } \\
\text { Dług. XI, s. } 219-220\end{array}$ & wyprawa na Psków \\
\hline
\end{tabular}

363 Dokument może być datowany na 14 II 1396 lub 5 III 1411 r., mniej prawdopodobnie - na 21 II 1426 r.; zob. wyżej, przyp. 197.

${ }^{364}$ J. Purc odnotowuje pobyt Witolda w Brasławiu 4 III 1426 r., jednak powołuje się na list, w którym mowa jest o jego zamiarze dotarcia tam 4 III 1427 r. (zob. niżej pod tą datą).

365 Witold zerwał pokój z Pskowem 30 IV 1426 r., 4 tygodnie przed planowanym rozpoczęciem działań wojennych; LUB VII 494. 


\begin{tabular}{|c|c|c|c|c|}
\hline \multicolumn{2}{|c|}{ Data } & \multirow{2}{*}{$\begin{array}{r}\text { Miejsce } \\
\text { Woronacz }\end{array}$} & \multirow{2}{*}{\begin{tabular}{l}
\multicolumn{1}{c}{ Źródło } \\
ПЛ I, s. 36-37; ПЛ II, \\
s. 40-41, 121-124; \\
LMAVB RS, F 15-73, \\
s. 29
\end{tabular}} & \multirow[t]{2}{*}{ Uwagi } \\
\hline & $5-25$ & & & \\
\hline & po 25 & Troki $^{366}$ & CEV 1247 & \\
\hline $\mathrm{X}$ & 18 & Euck & CEV 1248 & $\begin{array}{l}\text { spotkanie z Jagiełłą poświad- } \\
\text { czonym w Łucku } 18 \text { X } \\
1426 \text { r. (Gąsiorowski } 2015 \text {, } \\
\text { s. } 108 \text { ), wtedy tam na zjazd } \\
\text { władców zostali wysłani } \\
\text { szpiedzy krzyżaccy } \\
\text { (GStAPK, OBA 4658) }\end{array}$ \\
\hline XI & 11 & Euck (plan) ${ }^{367}$ & GStAPK, OBA 4658 & $\begin{array}{l}\text { wysłanie szpiega na zjazd } \\
\text { Jagiełły i Witolda do Łucka }\end{array}$ \\
\hline XII & & Litwa (?) & Dług. XI, s. 222 & $\begin{array}{l}\text { spotkanie z Jagiełłą poświad- } \\
\text { czonym w WKL w końcu } \\
\text { grudnia } 1426 \text { - styczniu } \\
1427 \text { r. (Gąsiorowski } 2015 \text {, } \\
\text { s. } 108-109 \text { ) }\end{array}$ \\
\hline \multicolumn{5}{|c|}{1427} \\
\hline \multirow[t]{2}{*}{ I } & 6 & Wilno & $\begin{array}{l}\text { ПЛ І, s. } 37-38 \text {; ПЛ ІІ, } \\
\text { s. } 41-42,121-124\end{array}$ & \\
\hline & 27 & Merecz & CEV 1265 & \\
\hline \multirow{2}{*}{\multicolumn{2}{|c|}{ przed 7 III }} & Wilno & CEV 1269 & \\
\hline & & Troki & CEV 1269 & \\
\hline \multirow[t]{3}{*}{ III } & 4 & Brasław (plan) & $\begin{array}{l}\text { GStAPK, OBA } 4673= \\
\text { LUB VII } 549^{*}\end{array}$ & $\begin{array}{l}\text { planowane na ten czas spo- } \\
\text { tkanie Witolda z Jagiełłą nie } \\
\text { doszło do skutku, ponieważ } \\
\text { król przebywał w Lublinie } \\
\text { (Gąsiorowski } 2015, \text { s. } 109 \text { ) }\end{array}$ \\
\hline & 17 & Dubicze & CEV 1270 & \\
\hline & po 31 & Litwa (WKL?) & $\begin{array}{l}\text { ПЛ І, s. 38; ПЛ IІ, s. 42, } \\
124\end{array}$ & \\
\hline
\end{tabular}

366 J. Purc odnotowuje pobyt Witolda w Dubiczach 24 IX 1426 r., powołując się na IC I 1214, jednak w rzeczywistości jest to list z 26 II 1426 r. (zob. pod tą datą).

367 Zupełnie inaczej Witold przedstawiał swoje plany w liście do wielkiego mistrza krzyżackiego Paula von Rusdorf z 28 X 1426 r.: według tego źródła zamierzał być w Grodnie 11 listopada, stąd planował wyruszyć do Jeleniego Dworu i zatrzymać się tam 14-17 listopada, by następnie udać się do Kowna lub Niemnem do Jurborka, a na Boże Narodzenie być u króla w Krakowie; LMAVB RS, F 15-73, s. 444-445. Jak widać, plan ten nie doszedł do skutku, o ile nie był celową dezinformacją. 


\begin{tabular}{|c|c|c|c|c|}
\hline \multicolumn{2}{|c|}{ Data } & Miejsce & Źródło & Uwagi \\
\hline \multirow[t]{3}{*}{ IV } & 6 & Berszty $^{368}$ & CEV 1273 & \\
\hline & $7-20$ & $\begin{array}{l}\text { Grodno i jego } \\
\text { okolice (plan) }\end{array}$ & CEV 1273 & \\
\hline & po 20 & $\begin{array}{l}\text { podróż } \\
\text { w górę Nie- } \\
\text { mna, w stronę } \\
\text { Kowna (plan) }\end{array}$ & CEV 1273 & \\
\hline $\mathrm{V}$ & 8 & Jurbork & CEV 1286 & \\
\hline \multirow[t]{5}{*}{ VI } & 6 & Troki & CEV 1288 & \\
\hline & 22 & Międzyrzecz & CEV 1290 & \\
\hline & & Troki & CEV 1329 & \\
\hline & $\begin{array}{l}\text { między } \\
22 \text { i } 30\end{array}$ & $\begin{array}{l}\text { Krewo } \\
\text { („,czwarty noc- } \\
\text { leg od Trok”) }\end{array}$ & CEV 1292, 1329 & \\
\hline & 30 & Mińsk 369 & \multirow{2}{*}{$\begin{array}{l}\text { LUB VII } 648= \\
\text { CEV } 1291\end{array}$} & \\
\hline \multirow[t]{6}{*}{ VII } & 3 & $\begin{array}{l}3 \text { dni drogi od } \\
\text { Mińska }\end{array}$ & & \\
\hline & 14 & Krzyczów & CEV 1292 & \\
\hline & & Starodub $^{370}$ & CEV 1329 & \\
\hline & & $\begin{array}{l}\text { Trubczewsk } \\
(?)^{371}\end{array}$ & CEV 1329 & \\
\hline & & $\begin{array}{l}\text { Mezeck (Mys- } \\
\text { sensytk) }\end{array}$ & CEV 1329 & \\
\hline & & Mceńsk (?) 372 & CEV 1329 & $\begin{array}{l}\text { po drodze z Mceńska do } \\
\text { Smoleńska - spotkanie } \\
\text { z książętami Perejasławia } \\
\text { (Riazańskiego), Prońska } \\
\text { i domu nowosilsko-odojew- } \\
\text { skiego }\end{array}$ \\
\hline
\end{tabular}

368 W nagłówku w CEV jako miejsce wystawienia listu mylnie podano Brześć.

369 O niedawnym (bez dokładnych dat) pobycie u Witolda w Mińsku (,in Litten eyn stat genant Menczk") pisali rycerze Jorge von Enzenberg i Hans von Blankenberg w liście do wielkiego mistrza z Torunia 13 VIII 1427 r.; GStAPK, OBA 4801.

370 Mowa tu o przyjęciu Witolda przez Zygmunta Kiejstutowicza, którego centrum księstwa leżało w Starodubie; Б. Барвіньский, Історичні причинки, t. 1, Жовква 1908, s. 66-68. O podróży Witolda do Staroduba mówi też późniejsze źródło (AS III 23).

${ }^{371} \mathrm{~W}$ liście miasto nienazwane, mowa jest o spotkaniu ze Świdrygiełłą. Trubczewsk był jednym z centrów jego księstwa; CEV 1034.

372 Tak samo przedstawia trasę podróży Witolda D. Iwanow; zob. Д.И. Иванов, op. cit., s. 101-102. Natomiast inni badacze uważają, że pod nazwą Myssensytk w liście Henne występuje Mceńsk; В.А. Варонін, Да пытання аб часе і абставінах ухавання грашова-рэчавага скарбу каля 
вёскі Літва Маладзечанскага раёна Мінскай вобласиі, „Studia Numismatica Albaruthenica” 1, 2011, s. 101; Р.А. Беспалов, К вопросу о времени запустения южной части Новосильско-Одоевского княжества, w: Город Средневековья и раннего Нового времени: археология, история. Материалы IV всероссийского семинара. Ноябрь 2011 г., red. И.Г. Бурцев, Тула 2013, s. 88-91; А.У. Ліцкевіч, „Срэбны каваль” Хацабей 3-пад Маладзечна (ХV cm.). Яччэ раз пра магчымае паходжанне срэбных паясных набораў са скарбу каля в. Літва, „Беларуская даўніна" 1, 2014, s. 116. Najbardziej szczegółowo trasę przejazdu Witolda próbował rekonstruować R. Biespałow, który przedstawia ją następująco: Krzyczów - Starodub - Trubczewsk - Briańsk - Karaczew - Zwienigorod - Mceńsk - Czerń - Paszkowa Gać (nad rzeką Pławą) - Tuła - Riazań lub Kołomna - Lubuck - Smoleńsk. Jednak przy bliższej analizie okazuje się, że ta interpretacja bazuje na kilku przypuszczeniach, które nie znajdują poparcia w źródłach. Otóż Henne pisał do wielkiego mistrza: „Następnie przybył on do zamku nazywającego się Myssensytk, tam pojawiło się dużo Tatarów, którzy siedzią pod moim panem i w tym władztwie ze wszystkich stron i na wielu obrzeżach i oni dostarczyli mu koni, wielbłądów, łuki i inne liczne dary. Następnie przybył on do zamku do swojego poddanego, wojewody...” („Vart an quam her uf eyns hus Myssensytk genant, dar quamen Tateran vyl, de under myme hern gesesen synt in dem gebyte van allen syden unde uff vylen eynden, unde brechten im pferde, cameyl, bogen ende sus vyl gyft. Do quam her vart uff eyn hus tzu sym undersasen, eyn wogebode..., GStAPK, OBA 4803 = CEV 1329, tekst skolacjonowany z oryginałem). A oto jak interpretuje słowo hus R. Biespałow: „W pierwszym wypadku zostało ono użyte dla oznaczenia grodu Mceńska. W drugim - dla oznaczenia miejsca pobytu wojewody, które najwidoczniej stanowiło twierdzę, wchodząc «tam» [to słowo zostało opuszczone w tłumaczeniu D.I. Iwanowa - S.P.], tj. do wewnątrz umocnień Mceńska. W tym czasie Mceńsk był jedynym znanym centrum województwa w regionie", Р.А. Беспалов, К вопросу о времени запустения..., s. 89, tłum. S.P. Jeżeli z ostatnim stwierdzeniem należy się zgodzić, to pierwsze bardzo przypomina hipotezę ad hoc, zbudowaną na podstawie niedokładnego rozumienia tekstu i na przywołaniu mniej dokładnego odczytu nazwy miejscowości (!) u Ł. Gołębiowskiego. Zamek Myssensytk nie jest bowiem tożsamy z Mceńskiem. Jeżeli przyjąć przejazd Witolda z Mezecka do Mceńska, to pozwala to objaśnić słowa z jego własnego listu: podczas jego niedawnej podróży na wschód od Smoleńska ziemia moskiewska leżała „po lewej ręce” od niego, a po spotkaniu z książętami riazańskimi, prońskimi i nowosilsko-odojewskimi on wracał do Smoleńska, a ziemia moskiewska pozostawała „po prawej ręce” odeń. Takie wskazówki w tym liście Witolda są dosyć dokładne: otóż dalej jest mowa o tym, że podczas podróży z Kijowa na Wołyń „po lewej ręce” od Witolda pozostanie Podole. Dalej R. Biespałow wychodzi z założenia, że „w 1427 r., przeprawiwszy się przez Pławę, Witold odwiedził swoje władztwa położone między ziemiami nowosilskich i riazańskich książąt", ibidem, s. 90, tłum. S.P. Jednak w swoim liście Witold pisał jedynie o zaproszeniu go przez tych książąt po złożeniu przez nich hołdu, a także o usytuowaniu terytorialnym jego władztw: „Każdy z nich zapraszał nas do siebie, gdy zbliżaliśmy się do granic ich ziem. Nasza ziemia i zamki są jeszcze dalej, poza nimi i między ich ziemiami, i oni bardzo uszanowali nas i obdarowali, tak że zarówno tam, jak i wszędzie, gdzie przebywaliśmy, każdego dnia byliśmy obdarowywani wielkimi i rozmaitymi darami: końmi, futrami sobolowymi, sobolami, złotem, jedwabnymi tkaninami i innymi” („Ir iclich hat uns czu sich gebetin, went wir ire lande rureten an den graniczen. Unsere landt und hwsere sint noch vordir, hynden, und czwuschen ire lande, und sie habin uns houch geert und begabet, also das wir dort und ouch o̊birall, wo wir qwomen seyn, mit grossen und manchen erungen alle tage begabit von pferden, von czobelenschuben, von czobeln, vom gôlde, von seydenen thüchern etc.", GStAPK, OBA $4802=$ CEV 1298, tekst skolacjonowany z oryginałem, tłum. S.P.). Czy Witold przyjął ich zaproszenia? Wydaje się, że nie: sam o tym niczego nie mówi; przysięgi sąsiednich książąt przyjął $\mathrm{w}$ swoich władztwach, także nie było pilnej potrzeby odwiedzania ich księstw, zwłaszcza że musiałby wtedy jechać 


\begin{tabular}{|c|c|c|c|c|}
\hline \multicolumn{2}{|c|}{ Data } & \multirow{2}{*}{$\begin{array}{c}\text { Miejsce } \\
\text { Smoleńsk }\end{array}$} & \multirow{2}{*}{\begin{tabular}{|r|} 
Źródłło \\
CEV 1298, 1329
\end{tabular}} & \multirow[t]{2}{*}{ Uwagi } \\
\hline VIII & $\begin{array}{l}13-16 \\
(\text { plan })\end{array}$ & & & \\
\hline \multirow[t]{5}{*}{ IX } & 8 & Kijów (plan) & CEV 1298, 1329 & \\
\hline & 17 & Ostróg & $\begin{array}{l}\text { Vitoldiana 108; Розов } 59 \\
\text { = Vitoldiana 109; Kur- } \\
\text { tyka. Rep. } 175^{\star}, 176^{*}\end{array}$ & \\
\hline & 22 & Łuck (plan) & CEV 1298, 1329 & \\
\hline & $\begin{array}{l}\text { między } \\
22 \text { a } 30\end{array}$ & $\begin{array}{l}\text { Włodzimierz } \\
\text { (plan) }\end{array}$ & CEV 1298 & \\
\hline & 30 & Horodło $^{373}$ & $\begin{array}{l}\text { CEV 1298; Vitoldiana } \\
\text { 110; Kurtyka. Rep. 177*; } \\
\text { KDW IX } 1134\end{array}$ & $\begin{array}{l}\text { spotkanie z Jagiełłą } \\
\text { (Gąsiorowski 2015, s. 110) }\end{array}$ \\
\hline \multirow{4}{*}{\multicolumn{2}{|c|}{ po 30 IX }} & Brześć (plan) & \multirow{4}{*}{ CEV 1298} & \\
\hline & & Mielnik (plan) & & \\
\hline & & $\begin{array}{l}\text { Drohiczyn } \\
\text { (plan) }\end{array}$ & & \\
\hline & & Grodno (plan) & & \\
\hline \multirow[t]{3}{*}{$\mathrm{X}$} & 26 & Kowno & CEV 1299 & $\begin{array}{l}\text { spotkanie z Jagiełłą } \\
\text { (Gąsiorowski 2015, s. 110) }\end{array}$ \\
\hline & 27 & Kowno $^{374}$ & CEV 1300 & \\
\hline & 28 & Troki (plan) $)^{375}$ & CEV 1299 & \\
\hline XI & 28 & Nowogródek & $\begin{array}{l}\text { KDKW } 100 \\
=\text { CEV } 1303^{*}\end{array}$ & \\
\hline XII & 25 & Troki (plan) & $\begin{array}{l}\text { CEV 1304; por. CEV } \\
1305,1306 ; 1307^{\star}\end{array}$ & $\begin{array}{l}\text { spotkanie z Jagiełłą poświad- } \\
\text { czonym w WKL od paź- } \\
\text { dziernika } 1427 \text { do początku } \\
\text { stycznia } 1428 \text { r. (Gąsiorowski } \\
2015 \text {, s. } 110-111 \text { ) }\end{array}$ \\
\hline
\end{tabular}

w przyspieszonym tempie (ale po co?); wreszcie kilka wierszy niżej Witold informuje o odmowie odwiedzin u swojej córki, wielkiej księżnej moskiewskiej, bo musiałby zrezygnować z zaplanowanej drogi i wydłużyć podróż o trzy dni. Ostatniej uwagi nie można traktować jako dokładnego określenia, a jedynie rozpatrywać jako w przybliżeniu, podobnie jak słowa Witolda o tym, że był on w odległości 100 mil na wschód od Smoleńska: w przeciwnym razie należałoby dopuścić możliwość, że przebywał on na wschód od Włodzimierza nad Klaźmą i Riazania.

373 Długosz błędnie datuje zjazd Jagiełły i Witolda w Horodle na 14 IX 1427 r.; Dług. XI, s. 226.

374 „Anno 27. Am tage [dalej puste miejsce o długości ok. $1 / 3-1 / 2$ linijki - S.P.] ist der konigk vonn Polen mitwoch gegen obendt komen gen Palangen, Wytoldt aber ist zu Kauenn bliben etc.," LMAVB RS, F 15-73, s. 497. Pobyt Jagiełły na Litwie poświadczony jest na początku i pod koniec roku; Gąsiorowski 2015, s. 84-85.

375 Stwierdzenie z listu Witolda o zamiarze udania się „do Trok do wtorku” („wir ab got wil bis dinstag von hinne ken Tracken cziheen willen", CEV 1299) może być rozumiane dwojako: albo 


\begin{tabular}{|c|c|c|c|c|}
\hline & Data & Miejsce & Źródło & Uwagi \\
\hline \multicolumn{5}{|c|}{1428} \\
\hline \multirow[t]{4}{*}{ I } & 14 & Troki & Kurtyka. Rep. $181^{\star}$ & \\
\hline & 15 & Troki & $\begin{array}{l}\text { CEV 1313; por. GStAPK, } \\
\text { OBA } 4859,4861,4862 \text {, } \\
4867,4883\end{array}$ & \\
\hline & 25 & Dowgi & LC I $115=$ CEV $1315^{\star 376}$ & \\
\hline & $29^{377}$ & Nowe Troki (?) & CEV 2 = Vitoldiana 75 & \\
\hline \multirow[t]{2}{*}{ II } & $11^{378}$ & Troki & CEV 1316 & \\
\hline & 27 & Worany & CEV 1320 & \\
\hline \multirow[t]{2}{*}{ IV } & 1 & Grodno & CEV $1321,1322^{*}$ & \\
\hline & 23 & Kowno & CEV 1323 & \\
\hline $\mathrm{V}$ & 23 & Troki (plan) & CEV 1323 & \\
\hline \multirow[t]{4}{*}{ VII } & $16-18$ & Wyszogród & ПЛ I, s. 38; ПЛ II, s. 42, & \multirow{4}{*}{$\begin{array}{l}\text { wyprawa na Nowogród } \\
\text { Wielki }^{379}\end{array}$} \\
\hline & $20-28$ & Porchów & & \\
\hline & 29 & Rżewa & $\begin{array}{l}\text { AGAD, MK, ks. } 89 \text {, } \\
\text { k. } 40 \mathrm{v}-41=\text { Kurtyka, } \\
\text { Rep. } 184^{* 380}\end{array}$ & \\
\hline & 30 & Rżewa & AS I $26^{381}$ & \\
\hline \multirow[t]{2}{*}{ VIII } & 18 & Nowogródek $^{382}$ & AS I 30 & \\
\hline & 22 & Nowogródek & CEV 1330 & \\
\hline
\end{tabular}

zamierzał wyjechać do Trok z Kowna nie później niż we wtorek, albo przebywać w Trokach do wtorku. W każdym razie planował być tam 28 października; por. Tęgowski 2006, s. 74.

376 W CEV regest błędnie datowany na 28 I $1428 \mathrm{r}$.

377 O datacji zob. Vitoldiana 75.

378 W CEV list błędnie datowano na 10 II $1428 \mathrm{r}$.

379 O zamiarze wyprawy na Nowogród Wielki Witold powiedział jeszcze 23 III 1428 r.; LMAVB RS, F 15-73, s. 231. Długosz w relacji o wyprawie nowogrodzkiej Witolda wspomina o oblężeniu Opoczki (Dług. XI, s. 243-246, bez dokładnych dat), ale ona znajdowała się nie w ziemi nowogrodzkiej, lecz w pskowskiej i była przez niego oblegana wcześniej - w $1426 \mathrm{r}$.

${ }^{380} \mathrm{~W}$ szesnastowiecznym odpisie $\mathrm{w}$ transliteracji polskiej dokument datowany na $6928 \mathrm{r}$., 7 indykcję, podczas gdy okresowi wyprawy Witolda na Nowogród odpowiada 6 indykcja. Pomyłka wynika z podobnego sposobu zapisu liter oznaczających cyfry 6 (S) i 7 (3) w skoropisie zachodnioruskim; zob. A.А. Турилов, Жалованная грамота Любарта Гедеминовича Луцзкой кабедре и ситуация на Волыни после гибели галицко-вольнских Рюриковичей, w: Восточная Европа в древности и средневековье. Проблемы источниковедения. XVII Чтения памяти чл.-корр. АН СССР В. Т. Пашуто; IV Чтения памяти д. и. н. А. А. Зимина, Москва, 19-22 апреля 2005 г., t. 2, Москва 2005, s. 266-267.

$381 \mathrm{~W}$ transumpcie $\mathrm{z}$ końca XVI w. w transliteracji polskiej dokument datowano na $6928 \mathrm{r}$., indykcję 6 , co razem z miejscem wystawienia wskazuje na rok 1428; zob. В.Д. Собчук, op. cit., s. 387-406.

${ }^{382}$ Znany z odpisu z połowy XVI w. dokument wystawiony wspólnie przez Witolda i Świdrygiełłę 


\begin{tabular}{|c|c|c|c|c|}
\hline \multicolumn{2}{|c|}{ Data } & \multirow{2}{*}{\begin{tabular}{|l|}
\multicolumn{1}{|c}{ Miejsce } \\
Worany \\
\end{tabular}} & \multirow{2}{*}{\begin{tabular}{|r|} 
Źródło \\
CEV 1331 \\
\end{tabular}} & \multirow[t]{2}{*}{ Uwagi } \\
\hline & 25 & & & \\
\hline $\mathrm{X}$ & 5 & Brześć & $\begin{array}{l}\text { KDKW } 106=\text { Vitoldiana } \\
111\end{array}$ & \\
\hline \multirow[t]{2}{*}{ XII } & 5 & Grodno & CEV 1335 & \\
\hline & 19 & Grodno & CEV 1336 & \\
\hline \multicolumn{5}{|c|}{1429} \\
\hline \multirow[t]{2}{*}{ I } & $5-17$ & Łuck & $\begin{array}{l}\text { CEV 1337, 1338; } \\
\text { Dług. XI, s. } 247\end{array}$ & \\
\hline & 31 & Łuck & Szybkowski 2002, s. 354 & \\
\hline \multirow[t]{4}{*}{ II } & 1 & $\begin{array}{l}\text { Turzysk (Wło- } \\
\text { dzimierski) }\end{array}$ & $\begin{array}{l}\text { Розов } 61=\text { Vitoldiana } \\
112\end{array}$ & \\
\hline & 8 & $\begin{array}{l}\text { w drodze na } \\
\text { Litwę (plan, } \\
\text { zamiast Trok) }\end{array}$ & CEV 1338 & \\
\hline & 13 & Ejszyszki & CEV 1344 & \\
\hline & 17 & Troki & CEV 1345 & \\
\hline \multirow[t]{3}{*}{ III } & 12 & Berszty & $\begin{array}{l}\text { NGAB, f. 1759, op. } 2 \text {, } \\
\text { s. } 5 \text {, ark. } 181-181 \mathrm{v}= \\
\text { Jaszczołt (przyg.), nr } 5\end{array}$ & \\
\hline & 16 & Berszty & CEV $1347^{383}$ & \\
\hline & 27 & Grodno & Dług. XI, s. 261 & \\
\hline \multirow[t]{2}{*}{ IV } & 17 & Jurbork & CEV 1347 (plan), 1351 & $\begin{array}{l}\text { zjazd } \mathrm{z} \text { wielkim mistrzem } \\
\text { krzyżackim }\end{array}$ \\
\hline & koniec & Troki (plan) & CEV 1347 & \\
\hline $\mathrm{V}$ & 3 & Troki & CEV 1351 & \\
\hline \multirow[t]{3}{*}{ VI } & początek & Troki ${ }^{384}$ & CEV 1360 & \\
\hline & 18 & Soleczniki & CEV 1360 & \\
\hline & 25 & Nowogródek & CEV 1361 & \\
\hline
\end{tabular}

w Łucku 15 VIII 1428 r.; ADS, sygn. D3, Acta offici Janoviensis Pontificatu Georgii Falczewski Presidente Offici Georgii Albino ut in superiori volumine annis 1543-1544, k. 161-161v. Badacze przypuszczają, że data roczna albo dzienna została zniekształcona - powinno być 8 września; zob. Tęgowski 2006, s. 75; W. Zawitkowska, op. cit., s. 187-188, przyp. 84, s. 273. Ponieważ Łuck w 1428 r. nie należał do Świdrygiełły (na początku 1429 r. wspomniany jest starosta łucki Witolda - Jursza), a ponadto nie jest znana praktyka wspólnego wystawienia dokumentów przez wielkiego księcia i dzielnicowego księcia w epoce Witolda, to bardziej prawdopodobne wydaje się, że wskazany dokument jest falsyfikatem.

${ }^{383}$ W nagłówku w CEV jako miejsce wystawienia listu mylnie podano Brześć.

${ }^{384}$ Witold pisze wielkiemu mistrzowi, że wysyłał z Trok do Jagiełły na Mazowsze rycerza Siostrzeńca, który przesłał mu odpowiedź królewską 18 czerwca. J. Purc powołuje się na wydawnictwo: 


\begin{tabular}{|c|c|c|c|c|}
\hline \multicolumn{2}{|c|}{ Data } & \multirow{2}{*}{$\begin{array}{r}\text { Miejsce } \\
\begin{array}{l}\text { Kamieniec } \\
\text { (Litewski) }\end{array}\end{array}$} & \multirow{2}{*}{\begin{tabular}{|l}
\multicolumn{1}{|c}{ Źródło } \\
ADS, sygn. D 22, \\
k. 50-51; sygn. D 154, \\
k. 192 = Jaszczołt \\
(przyg.), nr 4
\end{tabular}} & \multirow[t]{2}{*}{ Uwagi } \\
\hline & $29(?)^{385}$ & & & \\
\hline \multirow[t]{2}{*}{ VIII } & 2 & Kiernów & CEV 1368 & \\
\hline & 29 & Wilno & $\begin{array}{l}\text { Vitoldiana 113; NGAB, } \\
\text { f. } 1759 \text {, op. } 2 \text {, s. } 23, \\
\text { k. } 23 \mathrm{v}-24=\text { Jaszczołt } \\
\text { 2008, aneks 2, s. } 204-206 \\
\text { = Jaszczołt (przyg.), nr } 6\end{array}$ & \\
\hline \multirow[t]{2}{*}{ IX } & 9 & Jeleni Dwór & CEV 1380 & \\
\hline & 23 & Grodno & $\begin{array}{l}\text { CEV 1381, por. CEV } \\
1383\end{array}$ & \\
\hline \multicolumn{2}{|c|}{29 IX-3 X } & Grodno & Dług. XI, s. 265 & \\
\hline \multirow[t]{3}{*}{$\mathrm{X}$} & 3 & $\begin{array}{l}\text { Nowy Dwór } \\
\text { w } 3 \text { milach od } \\
\text { Grodna }\end{array}$ & CEV 1383 & \\
\hline & 4 & Żyrosław & CEV 1384 & \\
\hline & Po 4 & Wołkowysk & Dług. XI, s. 269 & \\
\hline XI & 11 & $\begin{array}{l}\text { Hrubieszów } \\
(\text { plan })^{386}\end{array}$ & $\begin{array}{l}\text { CEV 1383; GStAPK, } \\
\text { OBA } 5207=\text { CEV } 1387^{*}\end{array}$ & \\
\hline
\end{tabular}

Материаль для истории взаимных отношений России, Польши, Молдавии, Валахии и Турици в XIV-XVI вв., wybór B.А. Уляницкий, Москва 1887, nr 26к, s. 31. Jednak pod tym numerem przedrukowano jedynie wyciąg z CEV 1357.

385 W odpisach dokument datowany: „Actum et datum in Kamieniec ipso die Sancti Petri gloriosi apostoli sub anno Domini millessimo quadringentesimo vigesimo". Przyjmuję 29 VI 1429 r. ze względu na listę świadków i fakt, że pod koniec czerwca $1428 \mathrm{r}$. Witold miał już wyruszać na Nowogród Wielki.

386 Według streszczenia listu wielkiego mistrza do wójta Nowej Marchii z 28 X 1429 r. Witold napisał do tegoż, że zamierza spotkać się z królem polskim 8 dni po św. Marcinie na granicy Litwy; CEV $1387^{\star}$. W oryginale ten fragment brzmi następująco: „Syne durchluchtikeit [Witold - S.P.] hat uns wol geschreben, das siene hochwirdikeit habe eynen tag uff Martini geannampt in eigener person mit dem herren ko[nige] czu Polan czusampneczukomen, als verre is em der grosfurste wirt rathen, adir sost doch syne rethe dorczu vulmechtig fugen; abir sedir der czit hat uns unlanges der grosforste geschreben, das syne und ouch des herren koniges czu Polan rethe sollen acht tage noch Martini czusampnekomen of der grenitzen beider lande..., GStAPK, OBA 5207. Mamy więc tu jedynie informację o zjeździe Witolda z Jagiełłą wyznaczonym na 11 XI 1429 r. i spotkaniu ich doradców tydzień później. Najprawdopodobniej doszło tylko do zjazdu doradców, a sami władcy się nie spotkali, chociaż jeszcze w pierwszej połowie listopada Jagiełło rzeczywiście był obecny na Rusi koronnej (Gąsiorowski 2015, s. 114): po 20 X 1429 r. do Witolda przyjeżdżał komtur Balgi (CEV 1385), a wiadomo, że takie poselstwa najczęściej miały miejsce, gdy wielki książę przebywał na Litwie właściwej, stosunkowo blisko Prus. 


\begin{tabular}{|c|c|c|c|c|}
\hline \multicolumn{2}{|c|}{ Data } & \multirow{2}{*}{\begin{tabular}{|l|}
\multicolumn{1}{|c}{ Miejsce } \\
Troki \\
\end{tabular}} & \multirow{2}{*}{$\begin{aligned} & \text { Źródło } \\
& \text { KDKW } 108\end{aligned}$} & \multirow[t]{2}{*}{ Uwagi } \\
\hline & 27 & & & \\
\hline & $30^{387}$ & Przewałka & CEV 1391 & \\
\hline \multirow[t]{6}{*}{ XII } & 3 & Grodno & CEV 1390 & \\
\hline & 6 & Krynki & $\begin{array}{l}\text { CEV } 1390 \text { (plan), } 1398 \\
\text { (bez daty) }\end{array}$ & \\
\hline & 23 & Grodno & $\begin{array}{l}\text { Vitoldiana } 114^{\star}=\text { Szyb- } \\
\text { kowski } 1999, \text { s. } 299-300 \text {; } \\
\text { AGAD, terr. Droh. 2, } \\
\text { k. } 444-444 \mathrm{v}=\text { Jaszczołt } \\
\text { 2004, s. } 336=\text { Jaszczołt } \\
\text { (przyg.), nr } 7\end{array}$ & $\begin{array}{l}\text { spotkanie z Jagiełłą - } 10 \text { XII } \\
1429 \text { r. (jeszcze w Krynkach?) } \\
\text { (CEV 1390, 1397, 1399; } \\
\text { Gąsiorowski 2015, s. 115) }\end{array}$ \\
\hline & 28 & Grodno & АЛРГ 6; CEV 1397 & \\
\hline & 29 & Grodno & $\begin{array}{l}\text { Vitoldiana 115; } \\
\text { CEV } 1397 \text { (wyjazd) }\end{array}$ & \\
\hline & 31 & Przewałka & CEV 1392 & \\
\hline \multicolumn{5}{|c|}{1430} \\
\hline \multirow[t]{3}{*}{$\mathrm{I}$} & 1 & Przewałka & CEV 1397 & \\
\hline & 2 & Grodno & Vitoldiana 189 & \\
\hline & 9 & Grodno & CESXV III, dod. 5 & \\
\hline \multirow[t]{3}{*}{ II } & 7 & Troki & Vitoldiana 118 & \\
\hline & 11 & Troki & CEV 1399 & \\
\hline & 20 & Wilno & $\begin{array}{l}\text { Vitoldiana } 119=\text { Kur- } \\
\text { tyka. Rep. } 188^{*}\end{array}$ & \\
\hline \multirow[t]{2}{*}{ III } & 11 & Worany & CEV 1401 & \\
\hline & 15 & Dubicze & CEV 1402 & \\
\hline \multirow[t]{6}{*}{ IV } & 8 & Berszty 388 & CEV 1405 & \\
\hline & 14 & Grodno & CEV 1402 (plan) & \\
\hline & 15 & Grodno & CEV 1407 & \\
\hline & 16 & Grodno & $\begin{array}{l}\text { CEV 1408; Dług. XI, } \\
\text { s. } 283\end{array}$ & \\
\hline & 18 & $\begin{array}{l}\text { podróż Nie- } \\
\text { mnem do } \\
\text { Kowna (plan) }\end{array}$ & CEV 1405 & \\
\hline & 19 & Przełom & $\begin{array}{l}\text { Vitoldiana } 120=\text { MNK, } \\
\text { VIII - perg. } 15 \text { (oryg.) }{ }^{389}\end{array}$ & \\
\hline
\end{tabular}

387 W CEV pod błędną datą 4 XII $1429 \mathrm{r}$.

${ }^{388}$ W nagłówku w CEV jako miejsce wystawienia listu błędnie podano Brześć; Tęgowski 2006, s. 76. ${ }^{389}$ W nocie katalogowej oryginału data „feria quarta infra conductum festi solempnis Paschalis”, 


\begin{tabular}{|c|c|c|c|c|}
\hline \multicolumn{2}{|c|}{ Data } & \multirow{2}{*}{\begin{tabular}{l}
\multicolumn{1}{c}{ Miejsce } \\
hospodarski \\
„dwór \\
w 4 mile poni- \\
żej Kowna” \\
$\left(\right.$ Wilkija? $\left.{ }^{390}\right)$
\end{tabular}} & \multirow{2}{*}{\begin{tabular}{|l|} 
Źródło \\
CEV 1411
\end{tabular}} & \multirow[t]{2}{*}{ Uwagi } \\
\hline V & 3 & & & \\
\hline & 4 & Wilkija & CEV 1411 & \\
\hline & 14 & Kowno 391 & CEV 1353 & \\
\hline & 20 & Kowno & CEV 1414 & \\
\hline & 23 & Troki $^{392}$ & CEV 1352 & \\
\hline \multirow[t]{3}{*}{ VI } & 13 & Miedniki ${ }^{393}$ & CEV 1355 & \\
\hline & 15 & Oszmiana & CEV 1416 & \\
\hline & 20 & Mołodeczno ${ }^{394}$ & $\begin{array}{l}\text { CEV 1418, por. } \\
\text { CEV } 1358\end{array}$ & \\
\hline \multicolumn{2}{|c|}{ między 20 VI a 3 VIII } & Krasne Sioło & CESXV II $180^{395}$ & \\
\hline \multirow[t]{6}{*}{ VIII } & 3 & Worany & CEV 1426 & \\
\hline & 5 & Worany & CEV 1426 & \\
\hline & 8 & Dowgi & CEV 1427, 1428 & \\
\hline & 13 & Olita & CEV 1429 & \\
\hline & 17 & Dorsuniszki & CEV 1431 & \\
\hline & 24 & Kowno & CEV 1435 & \\
\hline \multirow[t]{4}{*}{ IX } & $4-7$ & Troki (plan) & CEV 1426, 1427 & \\
\hline & 8 & Troki $^{396}$ & CEV 1439 & \\
\hline & 10 & Troki & CEV 1441, 1442, 1444 & \\
\hline & 12 & Troki (plan) & CEV 1431 & \\
\hline
\end{tabular}

błędnie rozwiązana jako 26 IV 1430 r.; J. Tomaszewicz, Katalog dokumentów pergaminowich Muzeum Narodowego w Krakowie, Kraków 1992, s. 6-7.

${ }^{390}$ W liście nie podano nazwy dworu, ale Wilkija, w której został on napisany, leży mniej więcej we wskazanej odległości od Kowna w dół biegu Niemna.

391 W edycji pod błędną datą 8 V 1429 r.; zob. G. Błaszczyk, Burza koronacyjna. Dramatyczny fragment stosunków polsko-litewskich w XV wieku, Poznań 1998, s. 120; J. Sperka, Szafrańcowie herbu Stary Koń. Z dziejów kariery i awansu w późnośredniowiecznej Polsce, Katowice 2001, s. 182, przyp. 708.

392 W edycji pod błędną datą 3 V 1429 r.; zob. literaturę przywołaną w przyp. 391.

393 W edycji pod błędną datą $24 \mathrm{~V} 1429$ r.; zob. literaturę przywołaną w przyp. 391.

394 W edycji CEV 1358 pod błędną datą: czerwiec 1429 r.; zob. literaturę przywołaną w przyp. 391.

395 W edycji list Witolda ma datę „po 14 VI 1430” (w tym dniu został napisany list Jagiełły, na który odpowiadał Witold). Datacja uszczegółowiona na podstawie itinerarium Witolda.

3968 VIII $1430 \mathrm{r}$. Witold pisał do wielkiego mistrza, że zamierza wyjechać z Trok do Wilna 7 września, by 9 września spotkać przybywającego tam wielkiego księcia moskiewskiego; CEV 1427. 


\begin{tabular}{|c|c|c|c|c|}
\hline \multicolumn{2}{|c|}{ Data } & \multirow{2}{*}{\begin{tabular}{|l}
\multicolumn{1}{c}{ Miejsce } \\
Troki
\end{tabular}} & \multirow{2}{*}{\begin{tabular}{|l|}
\multicolumn{1}{|c|}{ Źródło } \\
CEV 1448 \\
\end{tabular}} & \multirow[t]{2}{*}{ Uwagi } \\
\hline & 17 & & & \\
\hline & 22 & Troki & CEV 1451 & \\
\hline & 25 & Troki & CEV 1451 (plan) & \\
\hline \multirow[t]{6}{*}{$\mathrm{X}$} & 9 & Wilno & CEV 1460 & \\
\hline & 11 & Wilno & Dług. XI, s. 292 & $\begin{array}{l}\text { spotkanie z Jagiełłą (Gąsio- } \\
\text { rowski 2015, s. 117) }\end{array}$ \\
\hline & 13 & Troki & CEV $1456^{397}$ & \\
\hline & 15 & Troki & CEV 1458, 1459 & \\
\hline & 21 & Troki & KDKW 109 & \\
\hline & 27 & Troki & Dług. XI, s. 301 & $\begin{array}{l}\text { śmierć Witolda, pogrzeb } \\
\text { w Wilnie } 3 \text { XI } 1430 \\
\text { (Dług. XI, s. 302) }\end{array}$ \\
\hline
\end{tabular}

397 Por. informację Długosza o pobycie Witolda w Trokach w ostatnich 14 dniach życia (Dług. XI, s. 300$)$. 


\section{Indeks geograficzny}

Indeks zestawia lata poświadczonych źródłowo pobytów Witolda w (albo przy) poszczególnych miejscowościach, regionach Wielkiego Księstwa Litewskiego oraz obiektach fizjograficznych (rzeki i jeziora). Przy tym wyjaśnienia, czy Witold rzeczywiście tam był, czy np. jedynie planował być znajdują się w powyższym itinerarium. Jako nazwę podstawową stosuję współczesną albo przyjętą w polskiej tradycji (o ile istnieje) nazwę danej miejscowości; w przypadku funkcjonowania innych źródłowych form nazwy (np. niemieckiej, ruskiej), znacznie różniących się od podstawowej, podaję je w nawiasach okrągłych kursywą. W objaśnieniu podaję identyfikację miejscowości na podstawie obecnego podziału administracyjnego, przy czym obecną nazwę podaję w językach państwowych danego kraju kursywą w nawiasach okrągłych; w przypadkach miejscowości na terenie Białorusi podaję nazwę białoruską i rosyjską obok siebie, o ile nie są tożsame. Lokalizacje i identyfikacje nastręczające poważne trudności objaśniam w przypisach, gdzie znajdują się odsyłacze do literatury. Indeks nie obejmuje przypisów i wprowadzenia.

Wykaz skrótów: jez. - jezioro, m. - miasto, niezident. - niezidentyfikowany, ob. - obecnie, obw. obwód, pow. - powiat, rej. - rejon, rz. - rzeka, w. - wieś, woj. - województwo, zam. - zamek, zident. - zidentyfikowany.

Bardyny (Bordenen), ob. w., pow. braniewski, woj. warmińsko-mazurskie, Polska - 1410

Bądzyń, ob. w., pow. łódzki wschodni, woj. łódzkie, Polska - 1410, 1419

Bełz, ob. m. (Белз), rej. sokalski, obw. lwowski, Ukraina - 1392

Berszty, ob. w. (Берumbl), rej. szczuczyński, obw. grodzieński, Białoruś - 1409 lub 1424 (?), $1414,1420,1422,1427,1429,1430$

Biecz, ob. m., pow. gorlicki, woj. małopolskie, Polska - 1410

Bielsk Podlaski, ob. m., pow. bielski, woj. podlaskie, Polska - 1410, 1422

Bieżuń, ob. m., pow. żuromiński, woj. mazowieckie, Polska - 1410

Birsztany, ob. m. (Birštonas), okręg kowieński, Litwa - 1401 (?), 1408 (?)

Biskupiec (Bischofswerder), ob. m., pow. nowomiejski, woj. warmińsko-mazurskie, Polska - 1414, 1422

Brasław, ob. m. (Браслай, Браслав), rej. brasławski, obw. witebski, Białoruś - 1426, 1427

Bratian, ob. w., pow. nowomiejski, woj. warmińsko-mazurskie, Polska - 1422

Briańsk, ob. m. (Брянск), obw. briański, Rosja 1406

Brodnica (Strasburg), ob. m., pow. brodnicki, woj. kujawsko-pomorskie, Polska - 1414

Brześć (Kujawski), ob. m., pow. włocławski, woj. kujawsko-pomorskie, Polska - 1411
Brześć(Ruski,Litewski), ob.m.(Брэст, Брест), obw. brzeski, Białoruś - 1409, 1410, 1415, 1417, 1421, 1422, 1424, 1425, 1427, 1428, 1429 Bug, rz. (Західний Буг, Заходні Буг), lewy dopływ Narwi - 1412, 1413, 1417

Chełm, ob. m., woj. lubelskie, Polska - 1394

Chełmno (Kulm), ob. m., pow. chełmiński, woj. kujawsko-pomorskie, Polska - 1422

Czerwińsk, ob. w. (Czerwińsk nad Wisła), pow. płoński, woj. mazowieckie, Polska - 1410, 1419, 1422

Dawidgródek (Городок Давьıов), оb. m. (Давыд-Гарадок, Давыд-Городок), rej. stoliński, obw. brzeski, Białoruś - 1418 lub 1424 (?) Dąbrówno (Gilgenburg), ob. w., pow. ostródzki, woj. warmińsko-mazurskie, Polska - 1410

Dniepr, rz. (Дніпро, Дняпро, Днепр), оb. na Ukrainie, Białorusi i w Rosji - 1399

Dobre Miasto (Guttstadt), ob. m., pow. olsztyński, woj. warmińsko-mazurskie, Polska - 1414

Dobrostany, ob. w. (Добростани), rej. jaworowski, obw. lwowski, Ukraina - 1415

Dobrotwór, ob. osiedle typu miejskiego (Добротвір), rej. kamionkobuski (kamionecki), obw. lwowski, Ukraina - 1417

Dokudowo, ob. w. (Дакудава 2, Докудово 2), rej. lidzki, obw. grodzieński, Białoruś - 1393

Dolatycze (Delatycze), оь. ж. (Дзяляцічь, Делятичи), rej. nowogródzki, obw. grodzieński, Białoruś - 1394 
Don, rz. (Дон), ob. w Rosji - 1397 (?)

Dorsuniszki, ob. w. (Darsūniškis), rej. koszedarski, okręg kowieński, Litwa - 1418 (?), 1430 Dowgi, ob. m. (Daugai), rej. olicki, Litwa 1415, 1420, 1428, 1430

Drohiczyn, ob. m., pow. siemiatycki, woj. podlaskie, Polska - 1410, 1420, 1422, 1424, 1427

Druck, ob. agromiasteczko (Друик), rej. tołoczyński, obw. witebski, Białoruś - 1393

Drwęca, rz., prawy dopływ Wisły - 1422

Dubicze, ob. w. (Dubičiai), rej. orański, okręg olicki, Litwa - 1396 lub 1411 lub 1426 (?), 1397, 1402 (?), 1403 (?), 1411, 1415, 1418, 1421, 1426, 1427,1430

Dubinki, ob. miasteczko (Dubingiai), rej. molecki, okręg uciański, Litwa - 1420

Dubissa, rz. (Dubysa), prawy dopływ Niemna 1393, 1395, 1396, 1403, 1413

Dubno, ob. agromiasteczko (Дубна), rej. mostowski, obw. grodzieński, Białoruś - 1416

Dyneburg, ob. na Łotwie, we włości naujeńskiej, $17 \mathrm{~km}$ w górę Dźwiny od m. Dyneburga (Daugavpils) - 1403

Dzierzgoń (Christburg), ob. m., pow. sztumski, woj. pomorskie, Polska - 1414

Dźwina, rz. (Daugava, Dauguva, Дзвіна, Заходняя Дзвіна, Западная Двина), ob. w Rosji, na Białorusi i Łotwie - 1413

Ejragoła, ob. m. (Ariogala), rej. rosieński, okręg kowieński, Litwa - 1418

Ejszyszki, ob. m. (Eišiškès), rej. solecznicki, okręg wileński, Litwa - 1429

Elbląg (Elbing), ob. m., pow. elbląski, woj. warmińsko-mazurskie, Polska - 1414

Friedeburg, zam., ob. nie istnieje, leżał na obszarze Litwy, zapewne nad Niewiażąą 1409 Gege, rz. (Gégè), prawy dopływ Rusnè - 1418

Gliniany, ob. m. (Глиняни), rej. złoczowski, obw. lwowski, Ukraina - 1411

Golub, ob. część m. Golubia-Dobrzynia, pow. golubsko-dobrzyński, woj. kujawsko-pomorskie, Polska - 1422

Goniądz, ob. m., pow. monecki, woj. podlaskie, Polska - 1417

Gotteswerder, zam., ob. nie istnieje, leżał na wyspie na Niemnie koło m. Kowna i ujścia Niewiaży - 1402

398 V. Almonaitis, Žemaitijos politine padetis 1380-1410 metais, Kaunas 1998, s. 124.
Grebów, ob. m. (Grybów), pow. nowosądecki, woj. małopolskie, Polska - 1410

Grodno, ob. m. (Гродна, Гродно), оbw. grodzieński, Białoruś - 1397, 1398, 1403, 1409, $1410,1411,1414,1415,1416,1417,1418,1419$, $1424,1425,1426,1427,1428,1429,1430$

Gródek Dawidów zob. Dawidgródek

Grunwald (Grünfelde), ob. w., pow. ostródzki, woj. mazursko-warmińskie, Polska - 1410

Gruti, dwór, ob. nie istnieje, prawdopodobnie leżał nad jez. Krudą (zob.) - 1405

Holszany (Olszany), ob. agromiasteczko (Гальшаны, Гольшаны), rej. oszmiański, obw. grodzieński, Białoruś - 1399

Horodło, ob. w., pow. hrubieszowski, woj. lubelskie, Polska - 1413, 1427

Hrubieszów, ob. m., pow. hrubieszowski, woj. lubelskie, Polska - 1412, 1429 (?)

Ilgi, dwór, prawdopodobnie leżał koło jez. Ilgaj (Ilgiai), ob. rej. ignaliński, okręg uciański, Litwa $-1420$

Jałtuszków (Jołtuszków), ob. w. (Ялтушків), rej. barski, obw. winnicki, Ukraina - 1424

Janczyn, ob. w. (Іванівка), rej. przemyślański, obw. lwowski, Ukraina - 1396

Jarosławska łąka, koło m. Jarosławia, ob. m., pow. jarosławski, woj. podkarpackie, Polska 1405

Jeleni Dwór, ob. mоże w. (Ельня), rej. lidzki lub szczuczyński, obw. grodzieński, lub osiedle typu miejskiego (Наваельня, Новоельня), rej. zdzięciolski; lub w. (Еленка; Стараельня, Староельня), ten sam rej., obw. grodzieński, Białoruś; lub w. (Alionys), rej. szyrwincki, okręg wileński, Litwa; lub w. (Еленец, Елянеи), rej. buda-koszelewski, obw. homelski, Białoruśs ${ }^{399}$ 1425,1429

399 Wcześniej za T. Baranauskasem skłaniałem się do lokalizacji Jeleniego Dworu na obszarze Litwy; idem, Pabaisko mūšis ir jo istorinis kontekstas, w: Pabaisko mūšis ir jo epocha, red. I. Vaškevičiūte, Vilnius 2017, s. 15-16; С.В. Полехов, Наследники Витовта. Династическая война в Великом княжестве Литовском в 30-е годы XV века, Москва 2015, s. 543, przyp. 6. O problemie jego lokalizacji w związku $\mathrm{z}$ datacją pobytu Witolda zob. wyżej, przyp. 362. 
Jeżewo, obiecnie w., pow. płocki, woj. mazowieckie, Polska - 1410

Jurbork (Georgenburg), ob. m. (Jurbarkas), rej. jurborski, okręg tauroski, Litwa - 1394, 1399 (?), 1403, 1426, 1427, 1429

Kamieniec (Litewski), ob. m. (Каменеи), rej. kamieniecki, obw. brzeski, Białoruś - 1404 (?), 1409,1429 (?)

Kiełczewice, ob. m. (Kiełczewice Dolne lub Kiełczewice Górne lub Kiełczewice Maryjskie lub Kiełczewice Pierwsze), pow. lubelski, woj. lubelskie, Polska - 1416

Kiernów, ob. miasteczko (Kernave), rej. szyrwincki, okręg wileński, Litwa - 1409, 1429

Kieżmark, ob. m. (Kežmarok), Słowacja wschodnia - 1410

Kijów, ob. m. (Кü̈в), stolica Ukrainy - 1394, 1399, 1411, 1415, 1427

Klimkówka, rz., ob. prawdopodobnie w Polsce, w woj. małopolskim lub podkarpackim - 1407

Kołomna, ob. m. (Коломна), rej. kołomieński, obw. moskiewski, Rosja - 1396

Kołoże, ob. grodzisko (Коложе), rej. opoczecki, obw. pskowski, Rosja - 1406

Kopyś, ob. osiedle typu miejskiego (Konsıcb), rej. orszański, obw. witebski, Białoruś - 1406

Kowalewo Pomorskie (Schönsee), ob. m., pow. golubsko-dobrzyński, woj. kujawsko-pomorskie, Polska - 1422

Kowaliki (Kowallik), ob. w., pow. nowomiejski, woj. warmińsko-mazurskie, Polska - 1410

Kowno, ob. m. (Kaunas), okręg kowieński, Litwa - 1398, 1401, 1404, 1405, 1406, 1408, $1409,1411,1412,1413,1415,1416,1417,1418$, 1420 (?), 1424, 1426, 1427, 1428, 1430

Kraków, ob. m., woj. małopolskie, Kraków 1399, 1402

Krasne Sioło, ob. w. (Краснае, Красное), rеј. mołodecki, obw. miński, Białoruś - 1430

Krewo, ob. agromiasteczko (Крэва, Крево), rej. smorgoński, obw. grodzieński, Białoruś - 1399, 1417,1427

Kroże, ob. miasteczko (Kražiai), rej. kielmski, okręg szawelski, Litwa - 1400

Kruda, jez., ob. zapewne na Litwie (Grūtas), okręg olicki, w pobliżu Druskienik - 1400 (?); zob. też Gruti

Krynki, ob. m., pow. sokólski, woj. podlaskie, Polska - 1429
Krzemieniec, ob. m. (Кременець), rej. krzemieniecki, obw. tarnopolski, Ukraina - 1421, 1424

Krzyczów, ob. m. (Крычаў, Кричев), rej. krzyczowski, obw. mohylewski, Białoruś - 1411, 1427

Krzyżpork, Krzyżbork (Kreuzburg), ob. w. (Славское), rej. bagrationowski, obw. kaliningradzki, Rosja - 1414

Lida, ob. m. (Ліда, Лида), rej. lidzki, obw. grodzieński, Białoruś - 1397, 1422

Lidzbark (Lautenburg), ob. m. (Lidzbark Welski), pow. działdowski, woj. warmińsko-mazurskie, Polska - 1410, 1422

Lidzbark (Warmiński, Heilsberg), ob. m., pow. lidzbarski, woj. warmińsko-mazurskie, Polska $-1414$

Lipsk, ob. agromiasteczko (Лincк, Лunск), rej. lachowicki, obw. brzeski, Białoruś - 1412 lub 1415 (?)

Litwa - 1397 (?), 1398 (?), 1399, 1400, 1401 (?), 1402 (?), 1404 (?), 1405 (?), 1407, 1408, $1409,1411,1412,1414,1415,1416,1417,1418$, $1419,1420,1421,1423,1424,1425,1426,1427$, 1429

Liw, ob. m., pow. węgrowski, woj. mazowieckie, Polska - 1410

Lubawa (Löbau), ob. m., pow. iławski, woj. mazursko-warmińskie, Polska - 1422

Lubicz, ob. w. (Lubicz Dolny i Lubicz Górny), pow. toruński, woj. kujawsko-pomorskie, Polska -1422

Lublin, ob. m., woj. lubelskie, Polska - 1403, 1410, 1421

Lwów, ob. m. (Львів), obw. lwowski, Ukraina 1393, 1411, 1415, 1417

Lańcut, ob. m., pow. łańcucki, woj. podkarpackie, Polska - 1410

Łuck, ob. m. (Луцъьк), obw. wołyński, Ukraina 1396, 1399, 1412, 1415, 1417, 1418 lub 1419 (?), 1420, 1424, 1426, 1427, 1429

Łyngmiany, ob. w. (Linkmenys), rej. ignaliński, okręg uciański, Litwa - 1416

Malbork (Marienburg), ob. m., pow. malborski, woj. pomorskie, Polska - 1410

Marienwerder, zam., ob. nie istnieje, leżał u ujścia Wilii do Niemna - 1402 (?)

Mazowsze - 1409, 1410

Mceńsk, ob. m. (Миенск), rej. mceński, obw. orłowski, Rosja - 1427 (?) 
Mełno, jez., ob. w Polsce, woj. kujawsko-pomorskie, pow. grudziądzki - 1422

Merecz, ob. miasteczko (Merkinè), rej. orański, okręg olicki, Litwa - 1396, 1401, 1413, 1425, 1427

Mereczanka, rz. (Merkys), prawy dopływ Niemna - 1413

Mezeck, ob. m. (Мещовск), rej. mieszczowski, obw. kałuski, Rosja - 1427

Miedniki, ob. w. (Medininkai), rej. wileński, okręg wileński, Litwa - 1396 (?), 1415, 1426, 1430

Mielnik, ob. w., pow. siemiatycki, woj. podlaskie, Polska - 1417, 1425, 1427

Międzyrzecz, ob. agromiasteczko (Міжэрычы, Мижеричи), rej. zelwieński, obw. grodzieński, Białoruś - 1427

Miłolub (Милолюбль), niezident., zapewne na Wołyniu lub na Rusi Koronnej ${ }^{400}-1405$

Mińsk, ob. m. (Мінск, Минск), stolica Białorusi - 1426, 1427

Mołodeczno, ob. m. (Маладзечна, Молодечно), rej. mołodeczański, obw. miński, Białoruś $-1399,1430$

Nadczarnomorze Północne - 1397 (?)

Narew, rz., prawy dopływ Wisły - 1409, 1410, 1422

Nidzica (Neidenburg), ob. m., pow. nidzicki, woj. warmińsko-mazurskie, Polska - 1414

400 Znany jest punkt osadniczy o takiej nazwie na Siewierszczyźnie; zob. С.В. Полехов, Список городов Свидригайла. Датировка и публикация, „Древняя Русь. Вопросы медиевистики" 2014, nr 4(58), s. 121, 125. Z tym Miłolubem identyfikuje go B.I. Любащенко, Галич у церковно-унійних планах Владислава Ягайла і митрополита Кипріяна, „Україна: культурна спадщина, національна свідомість, державність” 20, 2011, s. 446, przyp. 41. Jednak spotkanie Witolda z Jagiełłą, sądząc po dobrze opracowanym itinerarium tego ostatniego, musiało odbyć się gdzieś na Wołyniu, Podolu lub Rusi Koronnej, ale tam nie udaje się odnaleźć takie miejscowości. Nie wykluczam, że do spotkania doszło w wołyńskim Lubomlu, a latopisarz metropolicki, mylnie oddając głoski, nazwał go Miłolubem.
Niemen, rz. (Нёман, Неман, Neтипаs), ob. na Białorusi, Litwie i w Rosji - 1410, 1413, 1414, 1416, 1427, 1430

Nowe Troki $z o b$. Troki

Nowogród, ob. m. (Новгород Великий), obw. nowogrodzki, Rosja - 1401

Nowogródek (Litewski), ob. m. (Навагрудак, Новогрудок), rej. nowogródzki, obw. grodzieński, Białoruś - 1393, 1408, 1409, 1410, 1412 (?), $1415,1416,1420,1421,1422$ (?), 1425, 1427, 1428,1429

Nowy Dwór, niezident. - 1420

Nowy Dwór (o 1 milę od Trok), dwór, niezident. - 1426

Nowy Dwór (o 3 mile od Grodna), ob. agromiasteczko (Новы Двор, Новый Двор), rej. szczuczyński, obw. grodzieński, Białoruś - 1429

Nowy Dwór Mazowiecki, ob. m., pow. nowodworski, woj. mazowieckie, Polska - 1410

Nowy Korczyn, ob. m., pow. buski, woj. świętokrzyskie, Polska - 1394, 1417 (?)

Nowy Sącz, ob. m., pow. nowosądecki, woj. małopolskie, Polska - 1410

Nurzec, rz., prawy dopływ Bugu - 1410

Obolce, ob. agromiasteczko (Абольць, Обо$\pi b u, b l)$, rej. tołoczyński, obw. witebski, Białoruś - 1426

Olsztyn (Allenstein), ob. m., woj. warmińsko-mazurskie, Polska - 1414

Olsztynek(Hohenstein), ob. m.,pow. olsztyński, woj. warmińsko-mazurskie, Polska - 1410, 1414 Okonin (Ockeney), ob. w., pow. grudziądzki, woj. kujawsko-pomorskie, Polska - 1422

Olita, ob. m. (Alytus), okręg olicki, Litwa 1430

Olszany $z o b$. Holszany

Opoczka, ob. m. (Опочка), rej. opoczecki, obw. pskowski, Rosja - 1426

Orsza, ob. m. (Орma), rej. orszański, obw. witebski, Białoruś - 1393, 1406

Osa (Ossa), rz., prawy dopływ Wisły - 1422

Ostróg, ob. m. (Ocmpoz), rej. ostrogski, obw. rówieński, Ukraina - 1427

Ostrów (Ostrowo?), ob. może Ostrów Lubelski, m., pow. lubartowski, woj. lubelskie, Pol$\mathrm{ska}^{401}-1392$

401 Zob. różne wersje lokalizacji - koło Lidy, Grodna, na Mazowszu, na Podlasiu etc.: 
Oszmiana, ob. m. (Ашмяны, Ошмяны), rej. oszmiański, obw. grodzieński, Białoruś - 1430

Owrucz, ob. m. (Овруч), rej. owrucki, obw. żytomierski, Ukraina - 1394

Papowo Biskupie (Papau, Bischöflich Papau), ob. w., pow. chełmiński, woj. kujawsko-pomorskie, Polska - 1422

Pasłęk (Holland), ob. m., pow. elbląski, woj. warmińsko-mazurskie, Polska - 1410, 1414

Pasłęka (Passarge), rz., ob. w woj. warmińsko-mazurskim, Polska - 1410

Pilzno, ob. m., pow. dębicki, woj. podkarpackie, Polska - 1410

Pińsk, ob. m. (Пінск, Пинск), rej. piński, obw. brzeski, Białoruś - 1412 lub 1415 (?)

Pława, rz. (Плава), lewy dopływ Upy - 1406

Płock, ob. m., pow. płocki, woj. mazowieckie, Polska - 1411, 1422 (?)

Płocka ziemia - 1410

Podlasie - 1425

Podole - 1394

Pojegi, ob. m. (Pagégiai), okręg tauroski, Litwa $^{402}$ - 1418; zob. też Gege

Pokrzywno (Engelsburg), ob. w., pow. grudziądzkim, woj. kujawsko-pomorskie, Polska 1422

G. Błaszczyk, Dzieje stosunków polsko-litewskich, t. 2: Od Krewa do Lublina, cz. 1, Poznań, 2007, s. 39, przyp. 106. Leon Łauresz opowiada się za „lidzką" lokalizacją Ostrowa; Л.Л. Лаўрэш, Месиа заключэння Востраўскага пагаднення 1392 г., w: Ліда i Лідчына: да 685-годдзя з дня заснавання горада. Матэрыялы навукова-практычнай канферэниьі (Ліда, 3 кастрычніка 2008 г.), Ліда 2008, s. 44-48. Jednak do itinerarium Jagiełly najlepiej pasuje identyfikacja miejsca ugody ostrowskiej z Ostrowem Lubelskim, aczkolwiek pierwsze wzmianki o nim pochodzą z XV w.; zob. zwł. A. Sochacka, Mikroregion ostrowski $w$ średniowieczu - powstanie osady i parafii, w: Dzieje Ostrowa Lubelskiego, red. R. Szczygieł, Ostrów Lubelski 1998, s. 33-58; por. Gąsiorowski 2015, s. 136.

402 V. Almonaitis, Pagégiu vietovardis rašytiniuose šaltiniuose: pirmieji paminejimai, „Darbai ir dienos” 44, 2005, s. 211-223.
Połock, ob. m. (Полацк, Полочк), rej. połocki, obw. witebski, Białoruś - 1399, 1400, 1411, 1426

Porchow, ob. m. (Порхов), rej. porchowski, obw. pskowski, Rosja - 1428

Północne Nadczarnomorze $z o b$. Nadczarnomorze północne

Prabuty (Riesenburg), ob. m., pow. kwidzyński, woj. pomorskie, Polska - 1414, 1422

Przełom, ob. w. (Пералом, Перелом), rej. grodzieński, obw. grodzieński, Białoruś - 1424, 1430

Przewałka, ob. w. (Прывалкі, Привалки), rej. grodzieński, obw. grodzieński, Białoruś - 1416, 1429, 1430

Psel, rz. (Псёл, Псьол, Псел, Псло), lewy dopływ Dniepru - 1399

Pułtusk, ob. m., pow. pułtuski, woj. mazowieckie, Polska - 1422

Punia, ob. w. (Punia), rej. olicki, okręg olicki, Litwa - 1414 (?), 1418

Riazańska ziemia - 1396

Ritterswerder, zam., ob. nie istnieje, leżał na obszarze m. Kowna - 1392, 1394, 1402 (?)

Robakowo (Robkau), ob. w., pow. chełmiński, woj. kujawsko-pomorskie, Polska - 1422

Ropczyce, ob. m., pow. ropczycko-sędziszowski, woj. podkarpackie, Polska - 1410

Rubkowo, jez., ob. w Polsce, woj. warmińsko-mazurskie, pow. nowomiejski - 1410

Rudnik, dwór na Podlasiu, koło Bielska Podlaskiego, ob. na obszarze Polski - 1410

Rudomino, ob. w. (Rudamina), rej. wileński, okręg wileński, Litwa - 1394, 1422

Ruś - 1417, 1419, 1425

Rypin (Ripin), ob. m., pow. rypiński, woj. kujawsko-pomorskie, Polska - 1422

Rzeszów, ob. m., pow. rzeszowski, woj. podkarpackie, Polska - 1410

Rżewa (od 1435 r. - Pusta Rżewa), ob. zapewne w. (Пятница), rej. nowogrodzki, obw. nowogrodzki, Rosja ${ }^{403}-1428$

403 В.А. Аракчеев, Писиовые книги и локализация тетописных топонимов, w: Рефераты докладов и сообщений VI Всероссийского научно-практического совещения по изучению и изданию писиовых книг и других историко-геограбических 
Salin, wyspa na Niemnie u ujścia Niewiaży ${ }^{404}$ - 1398, 1413

Siemieliszki, ob. miasteczko (Semeliškès), rej. elektreński, okręg wileński, Litwa - 1418

Skała, ob. osiedle typu miejskiego (Скала-Подільська), rej. borszczowski, obw. tarnopolski, Ukraina - 1424

Słonim, ob. m. (Слонім, Слоним), rej. słonimski, obw. grodzieński, Białoruś - 1410, 1419

Smoleńsk, ob. m. (Смоленск), obw. smoleński, Rosja - 1392 (?), 1395, 1396, 1399, 1401, 1404, $1411,1423,1427$

Soleczniki, ob. m. (Šalčininkai), rej. solecznicki, okręg wileński, Litwa - 1429

Stare Kowno, ob. na obszarze m. Kowna - 1396 Stare Troki, ob. w. (Senieji Trakai), rej. trocki, okręg wileński, Litwa - 1426

Starodub, ob. m. (Сmapoдyб), rej. starodubski, obw. briański, Rosja - 1427

Suła, rz. (Сула), lewy dopływ Dniepru - 1399

Suraż, ob. m., pow. białostocki, woj. podlaskie $-1420$

Szimna Woda, rz., niezident., zapewne ob. na Ukrainie - 1399

Toruń (Thorn), ob. m., woj. kujawsko-pomorskie, Polska - 1411

Troki (Nowe Troki), ob. m. (Trakai), rej. trocki, okręg wileński, Litwa - 1398 (?), 1399, 1400, 1401, 1408, 1409, 1410, 1411, 1412, 1413, 1414, $1415,1416,1417,1418,1420,1421,1422,1423$, $1424,1425,1426,1427,1428,1429,1430$

Trubczewsk (Trubeck), ob. m. (Трубчевск), rej. trubczewski, obw. briański, Rosja - 1427 (?)

Turznice (Tewernitz), ob. w., pow. grudziądzki, woj. kujawsko-pomorskie, Polska - 1422

Turzysk Włodzimierski, ob. osiedle typu miejskiego (Турійськ), rej. turzyski, obw. wołyński, Ukraina - 1429

Ugra, rz. (Угpa), lewy dopływ Oki - 1408

источников (Ферапонтово, 27-29 мая 1993 2.), Санкт-Петербург 1993, s. 68-71; Л.А. Бассалыго, В.Л. Янин, Историко-географический обзор новгородско-литовской границь, ш: В.Л. Янин, Новгород и Литва: Пограничные ситуации XIII-XV веков, Москва 1998, s. 154-158.

${ }^{404}$ W sprawie lokalizacji por. V. Urbanavičius, Kur buvo sudaryta Salyno sutartis, „Šviesa”
Urzow zob. Rżewa

Utukinie (?), niezident., nazwa zniekształcona -1417 (?)

Warszawa, ob. m., stolica Polski - 1410

Wądzyńskie jezioro (Wansen), ob. w Polsce, pow. brodnicki, woj. kujawsko-pomorskie 1422

Wiaźma, ob. m. (Вязьма), rej. wiazemski, obw. smoleński, Rosja - 1407

Wielona, ob. miasteczko (Veliuona), rej. jurborski, okręg tauroski, Litwa - 1411, 1413 (?), 1416, $1418,1420,1423$

Wilia, rz. (Вілія, Вилия, Neris), prawy dopływ Niemna - 1402, 1409

Wilkija, ob. m. (Vilkija), rej. kowieński, okręg kowieński, Litwa - 1426, 1430

Wilno, ob. m. (Vilnius), stolica Litwy - 1392 (?), 1394, 1395, 1397, 1400 (?), 1401, 1403, 1404, $1406,1407,1408,1409,1410,1411,1412,1413$, $1414,1415,1416,1417,1418,1419,1421,1422$, $1424,1425,1426,1427,1429,1430$

Wisła, rz., ob. w Polsce - 1410, 1411, 1419

Witebsk, ob. m. (Віцебск, Витебск), obw. witebski, Białoruś - 1393, 1411, 1413, 1426

Wizna, ob. m., pow. łomżyński, woj. podlaskie, Polska - 1396, 1414

Włocławek, ob. m., pow. włocławski, w woj. kujawsko-pomorskie, Polska - 1411

Włodzimierz, ob. m. (Володимир-Волинський), rej. włodzimierski, obw. wołyński, Ukraina - 1405, 1427

Wołkowysk, ob. m. (Ваўкавыск, Волковыск), rej. wołkowyski, obw. grodzieński, Białoruś 1429

Wołyń - 1405

Worany(Orany),ob.w.(Senoji Varena), rej.orański, okręg olicki, Litwa - 1413, 1414, 1416, 1417, 1418, 1420, 1421, 1423, 1424, 1425, 1428, 1430 Woronacz, ob. w. (Воронич), rej. puszkinogorskim, obw. pskowski, Rosja - 1406, 1426

Worskla, rz. (Ворскла), lewy dopływ Dniepru $-1399$

Wysoka (Hohendorf), ob. w., pow. działdowski, woj. warmińsko-mazurskie, Polska - 1410

Wyszogród, ob. w. (Bыmezopod), rej. dedowicki, obw. pskowski, Rosja - 1428

2018, nr 75(8298), s. 4 (za wskazówkę dziękuję R. Dediali). 
Zakroczym, ob. m., pow. nowodworski, woj. mazowieckie, Polska - 1414

Zamek św. Jana, nad Dnieprem, ob. nie istnieje, prawdopodobnie leżał na wyspie Tawań w dolnym biegu Dniepru lub na ter. wsi Tiaginki (Тягинка), rej. berysławski, obw. chersoński, Ukraina - 1398

Zasław, ob. m. (Заславль, Заслаўе), rej. miński, obw. miński, Białoruś - 1411 (?)

Zdzitów, ob. w. (Здитово, Здзітава), rej. bereski, obw. brzeski, Białoruś - 1410

Zieluń, ob. w., pow. żuromiński, woj. mazowieckie, Polska - 1410

Żmudź - 1400, 1405, 1413 (?), 1417, 1424

Żyrosław (Żyrosławka), dwór, ob. nie istnieje, leżał na obszarze obw. grodzieńskiego Białorusi, na południe od Grodna ${ }^{405}-1429$

Żytomierz, ob. m. (Житомир), obw. żytomierski, Ukraina - 1394

Żyżmory, ob. m. (Žiežmariai), rej. koszedarski, okręg kowieński, Litwa - 1409

Puszcza (Wildnis) - 1403

Step - $1414(?)$

405 W sprawie lokalizacji zob. Вялікі гістарычны атлас Беларусі, t. 1, Мінск 2009, s. 123; por. LM VI, nr 567 (za wskazówkę dziękuję dr. hab. Aleksandrowi I. Hruszy).

\section{Streszczenie}

Prezentowane itinerarium wielkiego księcia litewskiego Aleksandra Witolda z lat 1392-1430 zostało opracowane na podstawie bogatego zestawu źródeł, zarówno drukowanych, jak i dotąd niepublikowanych, przechowywanych w archiwach i bibliotekach Białorusi, Litwy, Niemiec, Polski, Rosji i Ukrainy. Uwzględniono przy tym krytykę poprzedniej wersji itinerarium Witolda, przygotowanej przez Jerzego Purca (1971), oraz literaturę poświęconą zagadnieniu mobilności władców w średniowiecznej Europie. Analiza wykazała, że w Wielkim Księstwie Litewskim nie ukształtował się system regularnych objazdów kraju, inaczej niż w sąsiednim Królestwie Polskim za Władysława Jagiełły. Hospodar litewski spędzał większość czasu na Litwie właściwej (Lithuania propria) i w ściśle związanej z nią ziemi grodzieńskiej, natomiast do peryferyjnych części władztwa (ziemie ruskie, Żmudź) i poza jego obszar wyjeżdżał jedynie w związku z realizacją konkretnych zadań, zarówno w zakresie polityki wewnętrznej (utwierdzenie władzy wielkiego księcia), jak i zagranicznej (spotkania z innymi władcami, wyprawy wojenne). Takie podróże wymagały wszechstronnego zabezpieczenia, planowania i organizacji ze znacznym wyprzedzeniem. Porównanie tej praktyki ze stosunkowo nielicznymi danymi o systemie sprawowania władzy we wcześniejszym okresie pozwala stwierdzić, że zanik systemu objazdów państwa nastąpił dosyć wcześnie, w związku z jego wzrostem terytorialnym i zagrożeniem krzyżackim w XIII-XIV w.

\section{Itinerary of Grand Duke Vytautas of Lithuania: 4/5 August 1392 - 27 October 1430 Summary}

The presented itinerary of Grand Duke Vytautas of Lithuania (1392-1430) is based on extensive source material, both published and unpublished, preserved in the archives and libraries of Belarus, Germany, Lithuania, Poland, Russia, and Ukraine. It also takes into account the critical opinions of the previous version of his itinerary, prepared by Jerzy Purc (1971), and the literature on the rulers' mobility in medieval Europe. In this context, it turns out that no system of the ruler's regular tours emerged in the Grand Duchy of Lithuania, unlike in the neighbouring Poland under Władysław Jagiełł. The grand duke of Lithuania spent most of his time in Lithuania proper (Lithuania propria) and in the neighbouring Grodno land, leaving the core of the state for the outlying districts (Ruthenian lands, Samogitia) and foreign states in connection with specific tasks of home and foreign 
policy, such as strengthening his power, meetings with other rulers and war expeditions. Such travels demanded comprehensive supply planning and organization in advance. The comparison of this practice with relatively scarce evidence on the system of exercising power in the earlier period makes it possible to determine that the system of state progresses disappeared quite early as the result of its territorial growth and the threat from the Teutonic Order in the $13^{\text {th }}$ and $14^{\text {th }}$ centuries.

\section{Wykaz skrótów}

ADS - Archiwum Diecezjalne w Siedlcach

AGAD - Archiwum Główne Akt Dawnych w Warszawie

Antanavičius 1994 - D. Antanavičius, Du neskelbti 1396 m. Vytauto raštai, „Lietuvos istorijos metraštis" 1993 [1994], s. 138-146

APT, Kat. I - Archiwum Państwowe w Toruniu, Katalog I

Arbusow 1911 - Zwölf Urkunden zu O. Stavenhagen: „Livland und die Schlacht bei Tannenberg”, oprac. L. Arbusow, „Sitzungsberichte der Gesellschaft fur Geschichte und Altertumskunde der Ostseeprovinzen Russlands" 1911, nr 1-2, s. 265-277

AS I - Archiwum książąt Lubartowiczów Sanguszków w Sławucie, t. 1: 1366-1506, wyd. Z.L. Radzimiński, P. Skobielski, B. Gorczak, Lwów 1887

AS III - Archiwum książąt Sanguszków w Sławucie, t. 3: 1432-1534, wyd. B. Gorczak, Lwów 1890

AUPL - Akta unji Polski z Litwą, 1385-1791, wyd. S. Kutrzeba, W. Semkowicz, Kraków 1932

$\mathrm{BCz}$ - Biblioteka Książąt Czartoryskich w Krakowie

BGDO I/II/III - Berichte der Generalprokuratoren des Deutschen Orden an der Kurie, t. 1-3, oprac. K. Forstreuter, H. Koeppen, Göttingen 1960-1971 (Veröffentlichungen der niedersächsischen Archivverwaltung, t. 12, 13, 21)

Biskup 1959 - M. Biskup, Z badań nad Wielka Wojną z Zakonem Krzyżackim, „Kwartalnik Historyczny" 66,1959 , nr 3, s. 671-715

Biskup 1993 - M. Biskup, Wojny Polski z Zakonem Krzyżackim (1308-1521), Gdańsk 1993

BPAN - Biblioteka Naukowa Polskiej Akademii Nauk

CC - Cronica conflictus Wladislai regis Poloniae cum Cruciferis anno 1410, wyd. Z. Celichowski, Poznań 1911

CDIAUL - Центральний державний історичний архів України, м. Львів (Centralne Państwowe Historyczne Archiwum Ukrainy we Lwowie)

CDP IV/V/VI - Codex diplomaticus Prussicus, t. 4-6, wyd. J. Voigt, Königsberg 1853, 1857, 1861

CESXV I/II/III - Codex epistolaris saeculi decimi quinti, t. 1, wyd. A. Sokołowski, J. Szujski, t. 2-3, wyd. A. Lewicki, Cracoviae 1876-1894 (Monumenta Medii Aevi Historica Res Gestas Poloniae Illustrantia, t. 2, 12, 14)

CEV - Codex epistolaris Vitoldi, magni ducis Lithuaniae, 1376-1430, wyd. A. Prochaska, Cracoviae 1882 (Monumenta Medii Aevi Historica Res Gestas Poloniae Illustrantia, t. 6)

CM I - Codex Mednicensis seu Samogitiae dioecesis, wyd. P. Jatulis, cz. 1: 1416.II.13-1609.IV.2, Roma 1984 (Fontes Historiae Lituaniae, t. 3)

Dług. X/X-XI/XI - J. Dlugossii, Annales seu Cronicae incliti Regni Poloniae, ks. 10: 1370-1405, ks. 10-11: 1406-1412, ks. 11: 1413-1430, Varsaviae 1985, 1997, 2000

Dokumenty 2004 - Dokumenty strony polsko-litewskiej pokoju metneńskiego z 1422 roku, wyd. P. Nowak, P. Pokora, Poznań 2004.

Dogiel IV - Codex diplomaticus Regni Poloniae et Magni Ducatus Lituaniae, t. 4, wyd. M. Dogiel, Vilnae 1764

EFE II - Elementa ad fontium editiones, t. 2: Liber disparata antiqua continens Alexandro Masoviensi episcopo Tridentino dicatus, wyd. E. Winkler, Romae 1960 
Gąsiorowski 2015 - A. Gąsiorowski, Itinerarium króla Władysława Jagiełty 1386-1434, Warszawa 2015 (Itineraria Jagiellonów, t. 2)

Grabski 1966 - A.F. Grabski, List Władysława Jagiełly $i$ Witolda do soboru w Konstancji (1417), „Nasza Przeszłość” 25, 1966, s. 277-284

GStAPK - Geheimes Staatsarchiv Preußischer Kulurbesitz, XX. Hauptabteilung

HUB V - Hansisches Urkundenbuch, t. 5: 1392 bis 1414, wyd. K. Kunze, Halle 1899

IA - Index actorum saeculi XV ad res publicas Poloniae spectantium, wyd. A. Lewicki, Cracoviae 1888 (Monumenta Medii Aevi Historica Res Gestas Poloniae Illustrantia, t. 11)

IC I - Index corporis historico-diplomatici Livoniae, Esthoniae, Curoniae oder Kurzer Auszug aus derjenigen Urkunden-Sammlung, welche für die Geschichte und das alte Staatsrecht Liv-, Ehst- und Kurland's... von den Ritterschaften Liv-, Ehst- und Kurland's zusammengebracht worden ist, cz. 1: Vom Jahre 1198 bis zum Jahre 1449, wyd. K.E. Napiersky, Dorpat-Riga 1833-1835

Jablonskis 1933 - K. Jablonskis, Nauji Vytauto laikotarpio aktai, „Praeitis” 2, 1933, s. 375-411

Jarmolik 1990 - W. Jarmolik, Pierwsza lokacja miejska na Podlasiu (Sokołów Podlaski - 1424 r.), „Studia Podlaskie” 1, 1990, s. 71-84

Jaszczołt (przyg.) - T. Jaszczołt, Niepublikowane dokumenty wielkiego księcia Witolda, art. w przyg. do druku, mps w zbiorach autora

Jaszczołt 2004 - T. Jaszczołt, Gmina Grodzisk k. Siemiatycz. Dzieje ziemi i mieszkańców, Grodzisk 2004

Jaszczołt 2008 - T. Jaszczołt, Kuczyńscy i Lubowiccy herbu Ślepowron (Korwin) w ziemi drohickiej od XV do połowy XVI wieku - zarys dziejów rodziny, „Ciechanowiecki Rocznik Muzealny” 4, 2008, s. $155-210$

Jóźwiak 2004 - S. Jóźwiak, Wywiad i kontrwywiad w państwie zakonu krzyżackiego w Prusach, Malbork 2004

KDKW - Kodeks dyplomatyczny katedry i diecezji wileńskiej, t. 1, wyd. J. Fijałek, W. Semkowicz, Kraków 1932-1948

KDL - Kodeks dyplomatyczny Litwy, wyd. E. Raczyński, Wrocław 1845

KDW IX - Kodeks dyplomatyczny Wielkopolski, t. 9, wyd. i oprac. A. Gąsiorowski, T. Jasiński, Warszawa-Poznań 1990

Klimas 1933 - P. Klimas, Ghillebert de Lannoy. Dvi jo kelionés Lietuvon Vytauto Didžiojo laikais (1413-14 ir 1421 metais), „Praeitis” 2, 1933, s. 94-157

Kłoczowski 1992 - J. Kłoczowski, Jagiełło $i$ Witold wobec prawosławnych: próba ich dowartościowania w 1417 roku, w: Balticum. Studia z dziejów polityki, gospodarki i kultury XII-XVII wieku. Ofiarowane Marianowi Biskupowi w 70. rocznice urodzin, red. Z.H. Nowak, Toruń, 1992, s. 175-179.

Krzyżanowski - Podwody kazimierskie 1407-1432, wyd. S. Krzyżanowski, Kraków 1909-1913 (Archiwum Komisji Historycznej, t. 11), s. 392-465

Kubon 2016 - S. Kubon, Die Außenpolitik des Deutschen Ordens unter Hochmeister Konrad von Jungingen (1393-1407), Göttingen 2016 (Nova Mediaevalia. Quellen und Studien zum europäischen Mittelalter, t. 15)

Kujot 1910 - S. Kujot, Rok 1410. Wojna, „Roczniki Towarzystwa Naukowego w Toruniu” 17, 1910, s. $56-350$

Kurtyka. Rep. - J. Kurtyka, Repertorium podolskie. Dokumenty do 1430 roku, w: idem, Podole w czasach jagiellońskich, Kraków 2011, s. 297-447

Kwiatkowski 2016 - Kwiatkowski K., Eine Sammlung von Quellenregesten und Quellenabschriften aus dem Kreis des Deutschen Ordens (1. Hälfte des 16. Jh.). Inhaltsübersicht und Editionsperspektiven, w: Editionswissenschaftliches Kolloquium 2015. Die Geschichte im Bild, red. H. Flachenecker, K. Kopiński, J. Tandecki, Toruń 2016, s. 343-354

LC I/II - Liber cancellariae Stanislai Ciołek, t. 1-2, wyd. J. Caro, Wien 1865-1871 
Liedtke 1932 - A. Liedtke, Nieznany list W. Ks. Litewskiego Witolda do Jana biskupa włocławskiego $z$ r. 1417, „Kwartalnik Historyczny” 46, 1932, s. 148-149

LIM - „Lietuvos istorijos metraštis”

Lites II - Lites ac res gestae inter Polonos Ordinemque Cruciferorum, t. 2, Posnaniae 1892

LM VI - Lietuvos metrika. Knyga nr. 6 (1494-1506). Užrašymų knyga 6, wyd. A. Baliulis, Vilnius 2007

LM XXV - Lietuvos metrika. Knyga nr. 25. Užrašymu knyga 25, wyd. D. Antanavičius, A. Baliulis, Vilnius 1997

LMAVB RS - Lietuvos Mokslų akademijos Vrublevskių bibliotekos, Rankraščių skyrius

LUB I, IV, V, VI, VII, VIII - Liv-, esth- und curländisches Urkundenbuch nebst Regesten, t. 1, 4-6, wyd. F.G. Bunge, Riga 1853-1873; Liv-, esth- und curländisches Urkundenbuch, t. 7-8, wyd. H. Hildebrand, Riga-Moskau 1881-1884

LVVA - Latvijas valsts vēstures arhīvs

Mikulski 2011 - J. Mikulski, Staroruski utwór panegiryczny „Pochwała Witolda” (XV w.). Rozbiór krytyczny, Kraków 2011, mps pracy magisterskiej, w zbiorach autora

MK - Metryka Koronna (w AGAD)

ML - Metryka Litewska (w AGAD)

MNK, VIII - Muzeum Narodowe w Krakowie, oddział VIII

MRPS IV - Matricularum Regni Poloniae summaria, excussis codicibus, qui in Chartophylacio Maximo Varsoviensi asservantur, cz. 4, t. 1, wyd. T. Wierzbowski, Varsoviae 1910

MTB - Das Marienburger Tresslerbuch der Jahre 1399-1409, wyd. E. Joachim, Königsberg 1896

Neitmann 1990 - K. Neitmann, Der Hochmeister des Deutschen Ordens in Preußen - ein Residenzherrscher unterwegs, Köln-Wien 1990 (Veröffentlichungen aus den Archiven Preussischer Kulturbesitz, t. 30)

NGAB - Нацыянальны гістарычны архіў Беларусі (Narodowe Archiwum Historyczne Białorusi)

NKRMK - Najstarsze księgi i rachunki miasta Krakowa od r. 1300 do 1400, wyd. F. Piekosiński, J. Szujski, Kraków 1878 (Monumenta Medii Aevi Historica Res Gestas Poloniae Illustrantia, t. 4)

NKRSME - Nowa ksiega rachunkowa Starego Miasta Elblaga 1404-1414, cz. 1-2, wyd. M. Pelech, Warszawa-Poznań-Toruń 1987-1989

Nowak 1971 - Z.H. Nowak, Dokument strony polsko-litewskiej traktatu przymierza z państwami unii kalmarskiej z 1419 roku, „Zapiski Historyczne” 36, 1971, nr 3, s. 65-73

OBA - Ordensbriefarchiv (w GStAPK)

OF - Ordensfoliant (w GStAPK)

Paravicini 1994 - W. Paravicini, Fürschriften und Testimonia. Der Dokumentationskreislauf der spätmittelalterlichen Adelsreise am Beispiel des kastilischen Ritters Alfonso Mudarra 1411-1412, w: Studien zum 15. Jahrhundert. Festschrift für Erich Meuthen, t. 2, wyd. J. Helmrath, H. Müller, München 1994, s. 903-936

Pelech 1986 - M. Pelech, Der verlorene Ordensfoliant 5 (früher Hochmeister-Registrant II) des Hist. Staatsarchivs Königsberg, w: Beiträge zur Geschichte des Deutschen Ordens, t. 1, red. U. Arnold, Marburg 1986, s. 123-180

Quirini-Popławska 2002 - D. Quirini-Popławska, Włoski handel czarnomorskimi niewolnikami w późnym średniowieczu, Kraków 2002

RD - Rachunki dworu króla Władysława Jagiełty i królowej Jadwigi z lat 1388 do 1420, wyd. F. Piekosiński, Kraków 1896 (Monumenta Medii Aevi Historica Res Gestas Poloniae Illustrantia, t. 15)

RGADA - Российский государственный архив древних актов (Rosyjskie Archiwum Państwowe Akt Dawnych w Moskwie)

RHD - Regesta historico-diplomatica Ordinis S. Mariae Theutonicorum, cz. 1-2: Register, oprac. E. Joachim, W. Hubatsch, Göttingen 1948-1973 
Rowell 2004 - S.C. Rowell, Du Europos pakraščiai. Lietuvos Didžiosios Kunigaikštystès ir ispanu karalysčiu ryšiai 1411-1412 m. ir 1434 m. tekstuose, „Lietuvos istorijos metraštis” 2003 [2004], nr 1, s. $149-188$

SD I/II - I. Daniłowicz, Skarbiec diplomatów papiezkich, cesarskich, krolewskich, książęcych..., t. 1-2, Wilno 1860-1862

SHRM - Supplementum ad Historica Russiae Monumenta, Petropoli 1848

Sochaniewicz 1925-1926 - K. Sochaniewicz, Najdawniejsze dyplomy Witolda w. ks. litewskiego (Przyczynek do dyplomatyki litewskiej), „Ateneum Wileńskie” 3, 1925-1926, s. 374-386

SRP I/II/III - Scriptores rerum Prussicarum. Die Geschichtsquellen der preussischen Vorzeit bis zum Untergange der Ordensherrschaft, t. 1-3, wyd. Th. Hirsch, M. Töppen, E. Strehlke, Leipzig 1861$-1866$

Stelmach 1981 - R. Stelmach, Listy i dokumenty Jagiellonów w WAP we Wrocławiu, „Teki Archiwalne" 18,1981 , s. 11-31

SVDO I - Die Staatsverträge des Deutschen Ordens in Preussen im 15. Jahrhundert, t. 1: 1398-1437, wyd. E. Weise, Königsberg 1939

Szweda 2009 - A. Szweda, Organizacja i technika dyplomacji polskiej w stosunkach z zakonem krzyzackim $w$ Prusach $w$ latach 1386-1454, Toruń 2009

Szybkowski 1999 - S. Szybkowski, Dokument wielkiego księcia litewskiego Witolda Kiejstutowicza dla Stanisława Milewskiego z 23 XII 1429 r., w: Ksiązęta, urzędnicy, złoczyńcy, red. B. Śliwiński, Gdańsk 1999 (Gdańskie Studia z Dziejów Średniowiecza, t. 6), s. 291-302

Szybkowski 2002 - S. Szybkowski, Dokument wielkiego księcia litewskiego Witolda dla młynarza łuckiego Piotra Luby z 31 I 1429 r., w: Kopijnicy, szyprowie, tenutariusze, red. B. Śliwiński, Gdańsk 2002 (Gdańskie Studia z Dziejów Średniowiecza, t. 8), s. 345-356

SŹ - „Studia Źródłoznawcze”

Tęgowski 1997 - J. Tęgowski, Sprawa przyłączenia Podola do Korony Polskiej w końcu XIV wieku, „Teki Krakowskie” 5, 1997, s. 155-176

Tęgowski 2001 - J. Tęgowski, Addenda do Kodeksu dyplomatycznego Wielkopolski, „Studia Źródłoznawcze" 39, 2001, s. 95-100

Tęgowski 2006 - J. Tęgowski, Uzupetnienia i uwagi do itinerarium Witolda Kiejstutowicza, „Studia Źródłoznawcze" 44, 2006, s. 67-76

Vitoldiana - Vitoldiana. Codex privilegiorum Vitoldi, magni ducis Lithuaniae, 1386-1430, wyd. J. Ochmański, Warszawa-Poznań 1986

Wiśniewski 1977 - J. Wiśniewski, Osadnictwo wschodniej Białostocczyzny: geneza, rozwój oraz zróżnicowanie i przemiany etniczne, „Acta Baltico-Slavica” 11, 1977, s. 7-80

WPL - S. Jóźwiak, K. Kwiatkowski, A. Szweda, S. Szybkowski, Wojna Polski i Litwy z Zakonem Krzyżackim $w$ latach 1409-1411, Malbork 2010

ZDM V - Zbiór dokumentów małopolskich, cz. 5: Dokumenty z lat 1401-1440, wyd. I. Sułkowska-Kuraś, S. Kuraś, Wrocław-Warszawa-Kraków 1970

$\mathrm{ZH}$ - „Zapiski Historyczne”

АЗР I - Акты, относящиеся к истории Западной России, собранные и изданные Археограбическою комиссиею, t. 1: 1340-1506, Санкт-Петербург 1846

АЗР II - Акты, относящиеся к истории Западной России, t. 2: 18-я и 32-я книги записей Литовской метрики. Метрика королевы Боны, Москва 2018 (Акты Российского государства. Государственные и корпоративные архивы XIII-XVII веков)

АЛРГ - Акты Литовско-Русского государства, t. 1: 1390-1529, wуd. М. Довнар-Запольский, Москва 1900

Афанасенко 2015 - Ю. Афанасенко, Новогрудский собор 1415 г. в иерковной политике великого князя Витовта, „Studia Historica Europae Orientalis” 8, 2015, s. 91-122 
BC I - Витебская старина, t. 1, wybór i oprac. А.П. Сапунов, Витебск 1883

ДДГ - Духовные и договорные грамоты великих и удельных князей XIV-XVI вв., oprac.

Л.В. Черепнин, Москва-Ленинград 1950

Журнал ТУАК - Журнал 115-го заседания Тверской ученой архивной комиссии, Тверь 1913

Кудрявцев 2003 - О.Ф. Кудрявцев, Великая Русь рыцаря Де Ланноа. Первое западное описание Руси, „Родина” 2003, nr 12, s. 76-79

Мицик 2018 - Albaruthenica. Студіï з історії Білорусі, t. 2, орrac. Ю. Мицик, Київ 2018

Мікульскі 2014 - Miscellanea $з$ архіўных і бібліятэчных сховішчаў (XIV-XVII cm.), oprac. Ю.М. Мікульскі, „Беларуская даўніна” 1, 2014, s. 123-184

НПЛ - Новгородская первая летопись стармего и младмего изводов, оргас. А.Н. Насонов, Москва-Ленинград 1950

ОР РГБ - Отдел рукописей Российской государственной библиотеки

ПГ I/II - Полочкие грамоты XIII - начала XVI века, t. 1-2, орrac. А.Л. Хорошкевич, С.В. Полехов, В.А. Воронин, А.И. Груша, А.А. Жлутко, Е.Р. Сквайрс, А.Г. Тюльпин, Москва 2015

ПЛ I/II - Псковские летописи, t. 1-2, орrac. А.Н. Насонов, Москва-Ленинград 1941-1955

Полехов 2018 - С.В. Полехов, Загадка грамоты Buтовта (Vitoldiana, № 11): XIV или ХІХ век?, „Slověne" 7, 2018, nr 2, s. 272-297

ПСРЛ - Полное собрание русских летописей

Розов - В. Розов, Українські грамоти, t. 1: XIV і перша половіна XV в., Київ 1928

ТЛ - М.Д. Присёлков, Троицкая летопись. Реконструкция текста, Москва-Ленинград 1950 (reprint: Санкт-Петербург 2002).

\section{Bibliografia}

\section{Źródła drukowane}

Akta unji Polski z Litwa, 1385-1791, wyd. S. Kutrzeba, W. Semkowicz, Kraków 1932.

Antanavičius D., Du neskelbti 1396 m. Vytauto raštai, „Lietuvos istorijos metraštis” 1993 [1994], s. $138-146$.

Archiwum książąt Lubartowiczów Sanguszków w Sławucie, t. 1: 1366-1506, wyd. Z.L. Radzimiński, P. Skobielski, B. Gorczak, Lwów 1887.

Archiwum książąt Sanguszków w Sławucie, t. 3: 1432-1534, wyd. B. Gorczak, Lwów 1890

Berichte der Generalprokuratoren des Deutschen Orden an der Kurie, t. 1-3, oprac. K. Forstreuter, H. Koeppen, Göttingen 1960-1971 (Veröffentlichungen der niedersächsischen Archivverwaltung, t. 12, 13, 21).

Biskup M., Z badań nad Wielką Wojna z Zakonem Krzyżackim, „Kwartalnik Historyczny” 66, 1959, nr 3, s. 671-715.

Boubín J., Tři korybutovské písemnosti (Materiálová studie s edicí), „Folia Historica Bohemica” 4, 1982, s. 219-232.

Bullarium Poloniae, t. 3: 1378-1417, wyd. I Sułkowska-Kuraś, S. Kuraś, Romae-Lublini 1998.

Chartularium Lithuaniae res gestas magni ducis Gedeminne illustrans. Gedimino laiškai, wyd. S.C. Rowell, Vilnius 2003.

Codex diplomaticus Brandenburgensis, cz. 2, t. 3, wyd. A.F. Riedel, Berlin 1846.

Codex diplomaticus Prussicus, t. 5-6, wyd. J. Voigt, Königsberg 1857-1861.

Codex diplomaticus Regni Poloniae et Magni Ducatus Lituaniae, t. 4, wyd. M. Dogiel, Vilnae 1764.

Codex epistolaris saeculi decimi quinti, t. 1, wyd. A. Sokołowski, J. Szujski, t. 2-3, wyd. A. Lewicki, Cracoviae 1876-1894 (Monumenta Medii Aevi Historica Res Gestas Poloniae Illustrantia, t. 2, 12, 14). 
Codex epistolaris Vitoldi, magni ducis Lithuaniae, 1376-1430, wyd. A. Prochaska, Cracoviae 1882 (Monumenta Medii Aevi Historica Res Gestas Poloniae Illustrantia, t. 6).

Codex Mednicensis seu Samogitiae dioecesis, wyd. P. Jatulis, cz. 1: 1416.II.13-1609.IV.2, Roma 1984 (Fontes Historiae Lituaniae, t. 3).

Cronica conflictus Wladislai regis Poloniae cum Cruciferis anno 1410, wyd. Z. Celichowski, Poznań 1911

Daniłowicz I., Skarbiec diplomatów papiezkich, cesarskich, krolewskich, książęcych..., t. 1-2, Wilno 1860-1862.

Dlugossii J., Annales seu Cronicae incliti Regni Poloniae, ks. 10: 1370-1405, ks. 10-11: 1406-1412, ks. 11: 1413-1430, Varsaviae 1985, 1997, 2000.

Dokumenty strony polsko-litewskiej pokoju metneńskiego z 1422 roku, wyd. P. Nowak, P. Pokora, Poznań 2004.

Das Elbinger Kriegsbuch (1383-1409). Rechnungen für städtische Aufgebote, oprac. D. Heckmann, współpr. K. Kwiatkowski, Köln-Weimar-Wien 2013 (Veröffentlichungen aus den Archiven Preussischer Kulturbesitz, t. 68).

Elementa ad fontium editiones, t. 2: Liber disparata antiqua continens Alexandro Masoviensi episcopo Tridentino dicatus, wyd. E. Winkler, Romae 1960.

Gmiterek H., Protokót komisji granicznej polsko-litewskiej z 1623 roku, „Res Historica” 21, 2005, s. 115-133.

Grabski A.F., List Władysława Jagiełty $i$ Witolda do soboru w Konstancji (1417), „Nasza Przeszłość” 25, 1966, s. 277-284.

Hansisches Urkundenbuch, t. 5: 1392 bis 1414, wyd. K. Kunze, Halle 1899.

Hildebrand Veckinchusen. Briefwechsel eines deutschen Kaufmanns im 15. Jahrhundert, wyd. W. Stieda, Leipzig 1921.

Index actorum saeculi XV ad res publicas Poloniae spectantium, wyd. A. Lewicki, Cracoviae 1888 (Monumenta Medii Aevi Historica Res Gestas Poloniae Illustrantia, t. 11).

Index corporis historico-diplomatici Livoniae, Esthoniae, Curoniae oder Kurzer Auszug aus derjenigen Urkunden-Sammlung, welche für die Geschichte und das alte Staatsrecht Liv-, Ehst- und Kurland's... von den Ritterschaften Liv-, Ehst- und Kurland's zusammengebracht worden ist, cz. 1: Vom Jahre 1198 bis zum Jahre 1449, wyd. K.E. Napiersky, Dorpat-Riga 1833-1835.

Inventarium omnium et singulorum privilegiorum, litterarum, diplomatum, scripturarum et monumetorum..., wyd. E. Rykaczewski, Lutetiae Parisiorum 1862.

Jablonskis K., Archyvinès smulkmenos, „Praeitis” 2, 1933, s. 412-436.

Jablonskis K., Nauji Vytauto laikotarpio aktai, „Praeitis” 2, 1933, s. 375-411.

Jaszczołt T., Niepublikowane dokumenty wielkiego księcia Witolda, art. w przyg. do druku, mps w zbiorach autora.

Kämmerei-Register der Stadt Riga 1348-1361 und 1405-1474, t. 1: Die Kämmerei-Register, wyd. A. von Bulmerincq, Leipzig 1909.

Kodeks dyplomatyczny katedry i diecezji wileńskiej, t. 1, wyd. J. Fijałek, W. Semkowicz, Kraków 1932-1948 .

Kodeks dyplomatyczny Litwy, wyd. E. Raczyński, Wrocław 1845.

Kraštas ir žmonés. Lietuvos geografiniai ir etnografiniai aprašymai (XIV-XIX a.), wyd. 2 uzup., wyd. J. Jurginis, A. Šidlauskas, Vilnius 1988.

Księga komturstwa gdańskiego, wyd. K. Ciesielska, I. Janosz-Biskupowa, Warszawa-Poznań-Toruń 1985.

Kubon S., Wiederaufgefundene Quellen des Deutschen Ordens aus der Zeit des Konstanzer Konzils vorwiegend zur Auseinandersetzung mit Polen-Litauen, „Jahrbuch für die Geschichte Mittelund Ostdeutschlands" 61, 2015, s. 3-37.

Kurtyka J., Repertorium podolskie. Dokumenty do 1430 roku, w: idem, Podole w czasach jagiellońskich, Kraków 2011, s. 297-447. 
Liber cancellariae Stanislai Ciołek, t. 1-2, wyd. J. Caro, Wien 1865-1871.

Liedtke A., Nieznany list W. Ks. Litewskiego Witolda do Jana biskupa włocławskiego z r. 1417, „Kwartalnik Historyczny" 46, 1932, s. 148-149.

Lietuvos metrika. Knyga nr. 6 (1494-1506). Užrašymu knyga 6, wyd. A. Baliulis, Vilnius 2007.

Lietuvos metrika. Knyga nr. 25. Užrašymų knyga 25, wyd. D. Antanavičius, A. Baliulis, Vilnius 1997.

Lites ac res gestae inter Polonos Ordinemque Cruciferorum, t. 2, Posnaniae 1892.

Liv-, esth- und curländisches Urkundenbuch, t. 7-8, wyd. H. Hildebrand, Riga-Moskau 1881-1884.

Liv-, esth- und curländisches Urkundenbuch nebst Regesten, t. 1, 4-6, wyd. F.G. Bunge, Riga 1853$-1873$.

Das Marienburger Tresslerbuch der Jahre 1399-1409, wyd. E. Joachim, Königsberg 1896.

Matricularum Regni Poloniae summaria, excussis codicibus, qui in Chartophylacio Maximo Varsoviensi asservantur, cz. 4, t. 1, wyd. T. Wierzbowski, Varsoviae 1910.

Miscellanеа з архіўных і бібліятэчных сховішчаў (XIV-XVII cm.), орrac. Ю.М. Мікульскі, „Беларуская даўніна" 1, 2014, s. 123-184.

Najstarsze ksieggi i rachunki miasta Krakowa od r. 1300 do 1400, wyd. F. Piekosiński, J. Szujski, Kraków 1878 (Monumenta Medii Aevi Historica Res Gestas Poloniae Illustrantia, t. 4).

Nowa ksiega rachunkowa Starego Miasta Elblaga 1404-1414, cz. 1-2, wyd. M. Pelech, Warszawa-Poznań-Toruń 1987-1989.

Nowak Z.H., Dokument strony polsko-litewskiej traktatu przymierza z państwami unii kalmarskiej z 1419 roku, „Zapiski Historyczne” 36, 1971, nr 3, s. 65-73.

Nowy kodeks dyplomatyczny Mazowsza, cz. 3: Dokumenty z lat 1356-1381, wyd. I. Sułkowska-Kuraś, S. Kuraś, Warszawa 2000.

Paravicini W., Fürschriften und Testimonia. Der Dokumentationskreislauf der spätmittelalterlichen Adelsreise am Beispiel des kastilischen Ritters Alfonso Mudarra 1411-1412, w: Studien zum 15. Jahrhundert. Festschrift für Erich Meuthen, t. 2, wyd. J. Helmrath, H. Müller, München 1994, s. 903-936.

Pelech M., Der verlorene Ordensfoliant 5 (früher Hochmeister-Registrant II) des Hist. Staatsarchivs Königsberg, w: Beiträge zur Geschichte des Deutschen Ordens, t. 1, red. U. Arnold, Marburg 1986, s. $123-180$.

Podwody kazimierskie 1407-1432, wyd. S. Krzyżanowski, Kraków 1909-1913 (Archiwum Komisji Historycznej, t. 11), s. 392-465.

Rachunki dworu króla Władysława Jagiełty i królowej Jadwigi z lat 1388 do 1420, wyd. F. Piekosiński, Kraków 1896 (Monumenta Medii Aevi Historica Res Gestas Poloniae Illustrantia, t. 15).

Rachunki królewskie z lat 1393-1395 i 1412. Rachunki podrzęctwa krakowskiego. Rachunki stacji nowosądeckiej, wyd. H. Wajs, Warszawa 1993.

Regesta historico-diplomatica Ordinis S. Mariae Theutonicorum, cz. 1-2: Register, oprac. E. Joachim, W. Hubatsch, Göttingen 1948-1973.

Regesten zu den Briefregistern des Deutschen Ordens, t. 2: Die Ordensfolianten 8, 9 und Zusatzmaterial. Mit einem Anhang: Die Abschriften aus den Briefregistern des Folianten APG 300, R/Ll, 74, oprac. S. Kubon, J. Sarnowsky, A. Souhr-Könighaus, Göttingen 2014 (Beihefte zum Preußischen Urkundenbuch, t. 2).

Rerum Concilii Constantiensis, t. 3, wyd. H. von der Hardt, Francofurti-Lipsiae 1698.

Rocznik świętokrzyski, wyd. A. Rutkowska-Płachcińska, Kraków 1996 (Monumenta Poloniae Historica. Nova series, t. 12).

Rowell S.C., Du Europos pakraščiai. Lietuvos Didžiosios Kunigaikštystès ir ispanu karalysčiu ryšiai 1411-1412 m. ir 1434 m. tekstuose, „Lietuvos istorijos metraštis” 2003 [2004], nr 1, s. 149-188.

Russisch-Livländische Urkunden, oprac. K.E. Napiersky, St. Petersburg 1868.

Scriptores rerum Prussicarum. Die Geschichtsquellen der preussischen Vorzeit bis zum Untergange der Ordensherrschaft, t. 1-3, wyd Th. Hirsch, M. Töppen, E. Strehlke, Leipzig 1861-1866. 
Die Staatsverträge des Deutschen Ordens in Preussen im 15. Jahrhundert, t. 1: 1398-1437, wyd. E. Weise, Königsberg 1939 (przedruk: Marburg 1970).

Stelmach R., Listy i dokumenty Jagiellonów w WAP we Wrocławiu, „Teki Archiwalne” 18, 1981, s. 11-31.

Supplementum ad Historica Russiae Monumenta, Petropoli 1848.

Szybkowski S., Dokument wielkiego księcia litewskiego Witolda dla młynarza łuckiego Piotra Luby z 31 I 1429 r., w: Kopijnicy, szyprowie, tenutariusze, red. B. Śliwiński, Gdańsk 2002 (Gdańskie Studia z Dziejów Średniowiecza, t. 8), s. 345-356.

Szybkowski S., Dokument wielkiego księcia litewskiego Witolda Kiejstutowicza dla Stanisława Milewskiego z 23 XII 1429 r., w: Książęta, urzędnicy, złoczyńcy, red. B. Śliwiński, Gdańsk 1999 (Gdańskie Studia z Dziejów Średniowiecza, t. 6), s. 291-302.

Tęgowski J., Addenda do Kodeksu dyplomatycznego Wielkopolski, „Studia Źródłoznawcze” 39, 2001, s. $95-100$.

Tomaszewicz J., Katalog dokumentów pergaminowich Muzeum Narodowego w Krakowie, Kraków 1992.

Urkundenbuch des Bisthums Culm, t. 2, wyd. C.P. Woelky, Danzig 1885.

Vitoldiana. Codex privilegiorum Vitoldi, magni ducis Lithuaniae, 1386-1430, wyd. J. Ochmański, Warszawa-Poznań 1986.

Zbiór dokumentów małopolskich, cz. 5: Dokumenty z lat 1401-1440, wyd. I. Sułkowska-Kuraś, S. Kuraś, Wrocław-Warszawa-Kraków 1970.

Zwölf Urkunden zu O. Stavenhagen: „Livland und die Schlacht bei Tannenberg”, oprac. L. Arbusow, „Sitzungsberichte der Gesellschaft fur Geschichte und Altertumskunde der Ostseeprovinzen Russlands" 1911, nr 1-2, s. 265-277.

Акты, издаваемье Виленскою комиссиею для разбора древних актов, t. 24: Акты о боярах, Вильна 1897.

Акты Литовско-Русского государства, t. 1: 1390-1529, wуd. М. Довнар-Запольский, Москва 1900.

Акты, относящиеся к истории Западной России, собранные и изданные Археографическою комиссиею, t. 1: 1340-1506, Санкт-Петербург 1846.

Акты, относящиеся к истории Западной России, t. 2: 18-я и 32-я книги записей Литовской метрики. Метрика королевы Боны, Москва 2018 (Акты Российского государства. Государственные и корпоративные архивы XIII-XVII веков).

Акты социально-экономической истории Северо-Восточной Руси кония XIV - начала XVI в., t. 1, red.Б.Д. Греков, Москва 1952; t. 2, орrac. И.А. Голубцов, red. Л.В. Черепнин, Москва 1958. Акты феодального землевладения и хозяйства XIV-XVI веков, сz. 1, орrac. С.В. Бахрушин, Л.В. Черепнин, Москва 1951.

Albaruthenica. Cmyдіï з історії Білорусі, t. 2, орrac. Ю. Мицик, Київ 2018

Бугославский Г., Сокращенная Литовская летопись начала XVI в., w: Смоленская старина, t. 1, сz. 2, Смоленск 1911, s. 1-19.

Витебская старина, t. 1, wybór i oprac. А.П. Сапунов, Витебск 1883.

Герберштейн С., Записки о Московии, t. 2, Москва 2008.

Духовные и договорные грамоты великих и удельных князей XIV-XVI вв., орrac. Л.В. Черепнин, Москва-Ленинград 1950.

Журнал 115-го заседания Тверской ученой архивной комиссии, Тверь 1913.

Кудрявцев О.Ф., Великая Русь рыиаря Де Ланноа. Первое западное описание Руси, „Родина” 2003, nr 12, s. 76-79.

Лазутка С., Гудавичюс Э., Привилегия евреям Витаутаса Великого 1388 года, Москва-Иерусалим 1993. 
Материаль для истории взаимных отночений России, Польщи, Молдавии, Валахии и Турции в XIV-XVI вв., wybór В.А. Уляницкий, Москва 1887.

Михалон Литвин, О нравах татар, литовцев и москвитян, орrac. А.Л. Хорошкевич, Москва 1994.

Новгородская первая летопись старшего и младшего изводов, орrас. А.Н. Насонов, Москва-Ленинград 1950.

Полехов С.В., Загадка грамоты Витовта (Vitoldiana, № 11): XIV или XIX век?, „Slověne” 7, 2018, nr 2, s. 272-297.

Полехов С.В., Список городов Свидригайла. Датировка и публикащия, „Древняя Русь. Вопросы медиевистики" 2014, nr 4(58), s. 111-125.

Полное собрание русских летописей, t. 2: Ипатьевская летопись, Москва 1908.

Полное собрание русских летописей, t. 4, сz. 1: Новгородская четвертая летопись, Москва 2000.

Полное собрание русских летописей, t. 6, сz. 1: Софийская первая летопись стармего извода, Москва 2000

Полное собрание русских летописей, t. 11: Летописный сборник, именуемый Патриаршей или Никоновской летописью, Москва 2000.

Полное собрание русских летописей, t. 15: Рогожский летописеи. Тверской сборник, Москва 2000.

Полное собрание русских летописей, t. 17: Западнорусские летописи, Москва 2008.

Полное собрание русских летописей, t. 18: Симеоновская летопись, Москва 2007.

Полное собрание русских летописей, t. 25: Московский летописный свод конца XV в., Москва 2004.

Полное собрание русских летописей, t. 35: Летописи белорусско-литовские, Москва 1980.

Полочкие грамоты ХIII - начала XVI века, t. 1-2, орrac. А.Л. Хорошкевич, С.В. Полехов, В.А. Воронин, А.И. Груша, А.А. Жлутко, Е.Р. Сквайрс, А.Г. Тюльпин, Москва 2015.

Присёлков М.Д., Троицкая тетопись. Реконструкция текста, Москва-Ленинград 1950 (reprint: Санкт-Петербург 2002).

Псковские летописи, t. 1-2, орrac. А.Н. Насонов, Москва-Ленинград 1941-1955.

Розов В., Українські грамоти, t. 1: XIV і перша половіна XV в., Київ 1928.

Русская историческая библиотека, t. 20: Литовская метрика, cz. 1, Петербург 1903.

Хорошкевич А.Л., Документы начала XV в. о русско-литовских отночениях, w: Культурные связи России и Польши ХI-ХХ вв., Москва 1998, s. 39-57.

\section{Opracowania}

Almonaitis V., Pagégiu vietovardis rašytiniuose šaltiniuose: pirmieji paminèjimai, „Darbai ir dienos” 44, 2005, s. 211-223.

Almonaitis V., Žemaitijos politine padètis 1380-1410 metais, Kaunas 1998.

Antanavičius D., 1380 ir $1412 \mathrm{~m}$. Vytauto falsifikatu Bresto dvasininkams genezé, „Lietuvos istorijos metraštis" 2003 [2004], nr 1, s. 41-70.

Aretin K.O. von, Das Reich ohne Hauptstadt? Die Multizentralität der Hauptstadtfunktionen im Reich bis 1806, w: Hauptstädte in europäischen Nationalstaaten, red. Th. Schieder, G. Brunn, München-Wien 1983 (Studien zur Geschichte des neunzehnten Jahrhunderts, t. 19), s. $5-13$.

Baliulis A., Mikulionis S., Miškinis A., Trakų miestas ir pilys. Istorija ir architektūra, Vilnius 1991.

Baranauskas T., Lietuvos valstybès ištakos, Vilnius 2000.

Baranauskas T., Pabaisko müšis ir jo istorinis kontekstas, w: Pabaisko mūšis ir jo epocha, red. I. Vaškevičiūtè, Vilnius 2017, s. 10-68. 
Baronas D., Rowell S.C., The Conversion of Lithuania. From Pagan Barbarians to Late Medieval Christians, Vilnius 2015.

Berges W., Das Reich ohne Hauptstadt, w: Das Hauptstadtproblem in der Geschichte. Festgabe zum 90. Geburtstag Friedrich Meineckes, gewidmet vom Friedrich-Meinecke-Institut an der Freien Universität Berlin, Tübingen 1952 (Jahrbuch für Geschichte des Deutschen Ostens, t. 1), s. 1-30.

Biskup M., Wojny Polski z Zakonem Krzyżackim (1308-1521), Gdańsk 1993.

Czwojdrak B., Liczebność dworów późnośredniowiecznych i wczesnonowożytnych władców polskich, „Roczniki Dziejów Społecznych i Gospodarczych” 76, 2016, s. 209-224.

Czwojdrak B., Zofia Holszańska. Studium o dworze i roli królowej w późnośredniowiecznej Polsce, Warszawa 2012.

Čapaite R., The Everyday Life of Grand Duke Vytautas of Lithuania According to Contemporary Correspondence, „Lithuanian Historical Studies” 8, 2003 [2005], s. 1-26.

Čapaitè R., Gotikinis kursyvas Lietuvos didžiojo kunigaikščio Vytauto raštinèje, Vilnius 2007.

Čapaitè R., Istorikas Antanas Vasiliauskas (Vasys) (1902-1974), „Mūsų praeitis” 2, 1992, s. 55-76.

Čapaite R., List jako narzędzie komunikacji wielkiego księcia litewskiego Witolda, „Studia Źródłoznawcze" 50, 2012, s. 41-56.

Čelkis T., Stan dróg lądowych i struktura systemu połączeń $w$ Wielkim Księstwie Litewskim $w$ końcu XV-XVII wieku, „Zapiski Historyczne” 79, 2014, nr 3, s. 39-61.

Čelkis T., „Valdovo keliai” Lietuvos Didžiosios Kunigaikštystès teritorinès struktūros sandaroje XV-XVI amžiuje, w: Lietuvos Statutas ir Lietuvos Didžiosios Kunigaikštystès bajoriškoji visuomenè, red. I. Valikonyte, L. Steponavičienè, Vilnius 2015, s. 247-259.

Čelkis T., Vieškeliu tinklo struktūra Lietuvos Didžiojoje Kunigaikštystèje XVI-XVII a., „Lietuvos istorijos metraštis" 2019, nr 1, s. 33-77.

Dąbrowski D., Książę w drodze. O mobilności Rurykowiczów w XIII w. na przykładzie Daniela Romanowicza. Klasyfikacja podróży, „Slavia Orientalis” 64, 2015, nr 1, s. 7-34.

Dąbrowski D., Książe w drodze. Warunki podróżowania Rurykowiczów w XIII w. na przykładzie Daniela Romanowicza, „Slavia Orientalis” 64, 2015, nr 2, s. 207-227.

Duby G., Mandrou R., Historia kultury francuskiej, wiek X-XX, tłum. H. Szumańska-Grossowa, Warszawa 1967.

Ehlers C., Um 1012. Wie sich ambulante zu residenter Herrschaft entwickelt hat, w: Die Macht des Königs: Herrschaft in Europa vom Frühmittelalter bis in die Neuzeit, red. B. Jussen, München 2005, s. 106-124.

Ekdahl S., Der Krieg zwischen dem Deutschen Orden und Polen-Litauen im Jahre 1422, „Zeitschrift für Ostforschung" 13, 1964, nr 4, s. 614-651.

Fałkowski W., Monarchia w poszukiwaniu nowego status quo. Sytuacja polityczna $w$ Koronie przed uniq horodelska, 1399-1413, „Prace Historyczne” 141, 2014, nr 2: Unia horodelska 1413, s. $195-220$.

Fijałek J., Dorsuniszki, „Kwartalnik Historyczny” 44, 1930, nr 1, s. 333-340.

Gauert A., Zum Itinerar Karls des Großen, w: Karl der Große. Lebenswerk und Nachleben, t. 1: Persönlichkeit und Geschichte, red. H. Beumann, Düsseldorf 1967, s. 307-321.

Gąsiorowski A., Długoszowe itineraria królewskie, „Roczniki Historyczne” 36, 1970, s. 109-126.

Gąsiorowski A., Itineraria $d w u$ ostatnich Jagiellonów, „Studia Historyczne” 16, 1973, nr 2(61), s. 249-275.

Gąsiorowski A., Itinerarium króla Władysława Jagiełty 1386-1434, Warszawa 2015 (Itineraria Jagiellonów, t. 2).

Gąsiorowski A., Podróże panującego w średniowiecznej Polsce, „Czasopismo Prawno-Historyczne” 25, 1973, nr 2, s. 41-67.

Gąsiorowski A., Polskie itineraria późnośredniowieczne, „Zapiski Historyczne” 50, 1985, nr 3, s. 221-237. 
Gąsiorowski A., Rec. pracy J. Purca, „Studia Źródłoznawcze” 18, 1973, s. 246-247.

Gąsiorowski A., Rex ambulans, „Quaestiones Medii Aevi” 1, 1977, s. 139-162.

Gąsiorowski A., Stacje królewskie w średniowiecznej Polsce, „Kwartalnik Historii Kultury Materialnej” 20, 1972, nr 2, s. 244-265.

Gąsiorowski A., Skierska I., Średniowieczna monarchia objazdowa. Władca w centralnych ośrodkach państwa, w: Sedes regni principales. Materiały z Konferencji. Sandomierz, 20-21 października 1997 r., Sandomierz 1999, s. 67-80.

Goyski M., Wzajemne stosunki Polski, Litwy i Zakonu w latach 1399-1404, Kraków 1906.

Grotefend H., Zeitrechnung des deutschen Mittelalters und der Neuzeit, t. 1, Hannover 1891, http:// bilder.manuscripta-mediaevalia.de/gaeste//grotefend/g_a.htm (dostęp: 9 X 2019).

Gudavičius E., Miestu atsiradimas Lietuvoje, Vilnius 1991.

Gudavičius E., Mindaugas, Vilnius 1998.

Gudavičius E., Rec.: Jerzy Ochmański. Litewska granica etniczna na wschodzie od epoki plemiennej do XVI wieku..., „Lietuvos istorijos metraštis” 1982 [1983], s. 117-120.

Hlaváček I., Höfe - Residenzen - Itinerare, Prag 2011.

Ivinskis Z., Trakų Galvés ežero salos pilis, „Vytauto Didžiojo Kultūros muziejaus metraštis” 1, 1941, s. $135-198$.

Jablonskis K., Lietuviški žodžiai senosios Lietuvos raštinių kalboje, cz. 1: Tekstai, Kaunas 1941.

Jähnig B., Die Quellen des historischen Staatsarchivs Königsberg zur Geschichte der deutsch-litauischen Beziehungen in der Zeit der Ordensherrschaft und des Herzogtums Preußen, w: Deutschland und Litauen. Bestandsaufnahmen und Aufgaben der historischen Forschung, red. N. Angermann, J. Tauber, Lüneburg 1995, s. 9-19.

Jarmolik W., Pierwsza lokacja miejska na Podlasiu (Sokołów Podlaski - 1424 r.), „Studia Podlaskie” 1, 1990, s. 71-84.

Jaszczołt T., Gmina Grodzisk k. Siemiatycz. Dzieje ziemi i mieszkańców, Grodzisk 2004.

Jaszczołt T., Kuczyńscy i Lubowiccy herbu Ślepowron (Korwin) w ziemi drohickiej od XV do połowy XVI wieku - zarys dziejów rodziny, „Ciechanowiecki Rocznik Muzealny” 4, 2008, s. $155-210$.

Jaworski R., Łowy Władysława Jagiełly, w: R. Jaworski, P. Chojnacki, Z biografistyki Polski późnego średniowiecza, red. M. Koczerska, Warszawa 2001 (Fasciculi Historici Novi, t. 4), s. 7-86.

Jogailos ir Vytauto laikai. Mokslinių straipsnių rinkinys, skirtas Žalgirio mūšio 600-osioms metinèms, Kaunas 2011.

Jóźwiak S., Wywiad i kontrwywiad w państwie zakonu krzyżackiego w Prusach, Malbork 2004.

Jóźwiak S., Kwiatkowski K., Szweda A., Szybkowski S., Wojna Polski i Litwy z Zakonem Krzyżackim w latach 1409-1411, Malbork 2010.

Jučas M., Vytautas Didysis, Vilnius 2013.

Jučas M., Žalgirio mūšis, Vilnius 1999.

Jurginis J., Baudžiavos įsigalèjimas Lietuvoje, Vilnius 1962.

Jurkiewicz J., „Podróże” chłopów Wielkiego Księstwa Litewskiego w XVI-XVIII w. (z zagadnień powinności transportowych włościan), w: „Młodsza Europa” od średniowiecza do współczesności. Prace ofiarowane Profesor Marii Barbarze Piechowiak Topolskiej w siedemdziesiąta rocznice urodzin, red. J. Jurkiewicz, R.M. Józefiak, W. Strzyżewski, Zielona Góra 2008, s. 301-320.

Jurkiewicz J., Powinności podwodowe włościan w Wielkim Księstwie Litewskim (XVI-XVIII w.). Z zagadnień ich terminologii i klasyfikacji, w: Istorijos akiračiai, Vilnius 2004, s. 101-126.

Kiaupa Z., 1408 metų Vytauto privilegija Kauno miestui, „Lietuvos istorijos metraštis” 1979 [1981], s. $5-19$.

Kitkauskas N., Vilniaus pilys: istorija, statyba, architektūra, Vilnius 2012.

Klimas P., Ghillebert de Lannoy. Dvi jo kelionès Lietuvon Vytauto Didžiojo laikais (1413-14 ir 1421 metais), „Praeitis” 2, 1933, s. 94-157. 
Kłoczowski J., Jagiełło $i$ Witold wobec prawosławnych: próba ich dowartościowania $w 1417$ roku, w: Balticum. Studia $z$ dziejów polityki, gospodarki i kultury XII-XVII wieku. Ofiarowane Marianowi Biskupowi w 70. rocznice urodzin, red. Z.H. Nowak, Toruń, 1992, s. 175-179.

Kolankowski L., Dzieje Wielkiego Księstwa Litewskiego za Jagiellonów, t. 1, Warszawa 1930.

Koneczny F., Dzieje Rosyi, t. 1, Warszawa 1917.

Korczak L., Znajomość spraw tureckich w Wielkim Księstwie Litewskim w XV wieku, „Zeszyty Naukowe Uniwersytetu Jagiellońskiego. Prace Historyczne”, z. 119: „Studia Polono-Danubiana et Balcanica" 8, 1995, s. 143-147.

Kornecka-Trafas A., Oleśnicki Jan, w: PSB, t. 23, Wrocław 1978, s. 763-764.

Kosman M., Dokumenty wielkiego księcia Witolda, „Studia Źródłoznawcze” 16, 1971, s. 139-169.

Kosman M., Kancelaria wielkiego księcia Witolda, „Studia Źródłoznawcze” 14, 1969, s. 91-119.

Kosman M., Problem stołecznych funkcji Wilna do połowy XVI wieku, „Zapiski Historyczne” 64, 1999, nr 3-4, s. 37-65.

Kozák P., Mezi centrem a periferii. Itinerár̆ pozdèjšího krále Zikmunda I. Starého z doby jeho pobytu $v$ Uhrách a v českých zemích (1498-1507), w: Jagiellonowie i ich świat. Dynastia królewska w drugiej połowie XV i w XVI wieku, red. B. Czwojdrak, J. Sperka, P. Węcowski, Kraków 2015 (Studia Jagiellonica, t. 2), s. 117-171.

Krajniak R., Itineraria Jagiellonów. Uwagi i uzupetnienia do kolejnych tomów serii, „Klio. Czasopismo Poświęcone Dziejom Polski i Powszechnym" 44, 2018, nr 1, s. 149-167.

Kubon S., Die Außenpolitik des Deutschen Ordens unter Hochmeister Konrad von Jungingen (1393-1407), Göttingen 2016 (Nova Mediaevalia. Quellen und Studien zum europäischen Mittelalter, t. 15).

Kuczyński S.K., Sochaniewicz Kazimierz Roman, w: PSB, t. 39, Warszawa-Kraków 1999-2000, s. 623-625.

Kuczyński S.M., Ziemie czernihowsko-siewierskie pod rządami Litwy, Warszawa 1936.

Kujot S., Rok 1410. Wojna, „Roczniki Towarzystwa Naukowego w Toruniu” 17, 1910, s. 56-350.

Kunigielis J., Litewskie miasta $w$ relacji Gilberta de Lannoy $z$ roku 1414, w: Вялікае Княства Літоускае: палітька, эканоміка, культура, red. А.А. Скеп'ян, Мінск 2017, s. 35-44.

Kuraszkiewicz W., Gramoty halicko-wołyńskie XIV-XV wieku. Studium językowe, Kraków 1934.

Kuraszkiewicz W., Gramoty XIV-XV wieku. Studjum filologiczne, „Byzantinoslavica” 4, 1932, s. 335-364.

Kurtyka J., Podole w średniowieczu i okresie nowożytnym. Obrotowe przedmurze na pograniczu cywilizacji, w: idem, Podole w czasach jagiellońskich, Kraków 2011, s. 91-160.

Kwiatkowski K., Neue Quellen aus dem Kreis des Deutschen Ordens zum Krieg von 1409-1411 (Teil 1), „Zapiski Historyczne” 75, 2010, nr 4, s. 67-112.

Kwiatkowski K., Eine Sammlung von Quellenregesten und Quellenabschriften aus dem Kreis des Deutschen Ordens (1. Hälfte des 16. Jh.). Inhaltsübersicht und Editionsperspektiven, w: Editionswissenschaftliches Kolloquium 2015. Die Geschichte im Bild, red. H. Flachenecker, K. Kopiński, J. Tandecki, Toruń 2016, s. 343-354.

Kwiatkowski K., Zakon Niemiecki jako „corporatio militaris”, cz. 1: Korporacja i krąg przynależacych do niej. Kulturowe i społeczne podstawy działalności militarnej zakonu w Prusach (do początku XV wieku), Toruń 2012 (Dzieje Zakonu Niemieckiego, t. 1).

Kwiatkowski K., Zygmunt Luksemburski wobec konfliktu Królestwa Polski i Wielkiego Księstwa Litwy z zakonem niemieckim wiosna 1410 roku - kilka nowych uwag, „Nowe Studia Grunwaldzkie” 2, 2016, s. 35-68.

Kwiatkowski K., Szweda A., Nieco uwag o książce Marka Radocha, „Zapiski Historyczne” 77, 2012, nr 3, s. 95-124.

Larczyńska A., Prawdziwe czy zmyślone? Źródła epistolarne i dokumentowe w formularzu księcia mazowieckiego Aleksandra. Próba rekonesansu badawczego, „Studia z Dziejów Średniowiecza” 18, 2014, s. 141-155. 
Leonavičiūtė I., Kariaunos vaidmuo kuriantis Lietuvos valstybei, w: Lietuvos valstybė XII-XVIII a., Vilnius 1997, s. 475-485.

Lietuvių karas su kryžiuočiais, red. J. Jurginis, Vilnius 1964.

Lietuvos istorija, t. 3, Vilnius 2012.

Lietuvos pilys, red. J. Jurginis, Vilnius 1971.

Ludwig F., Untersuchungen über die Reise- und Marschgeschwindigkeit im XII. und XIII. Jahrhundert. I. Die Itinerare der deutschen Könige und Kaiser, der französischen Könige und der Päpste, Berlin 1897.

Maleczyńska E., Rola polityczna królowej Zofii Holszańskiej na tle walki stronnictw w Polsce w latach 1422-1434, Lwów 1936.

Mickūnaitė G., A Medieval Parade?, w: ... The Man of Many Devices, who Wandered Full Many Ways... Festschrift in Honor of János M. Bak, red. B. Nagy, Budapest 1999, s. 277-280.

Mickūnaite G., Vytautas Didysis. Valdovo ịvaizdis, Vilnius 2008.

Mikulski J., Staroruski utwór panegiryczny „Pochwała Witolda” (XV w.). Rozbiór krytyczny, Kraków 2011, mps pracy magisterskiej, w zbiorach autora.

Müller-Mertens E., Die Reichsstruktur im Spiegel der Herrschaftspraxis Ottos des Grossen, Berlin 1980 (Forschungen zur mittelalterlichen Geschichte, t. 25).

Müller-Mertens E., Huschner W., Reichsintegration im Spiegel der Herrschaftspraxis Kaiser Konrads II., Weimar 1992 (Forschungen zur mittelalterlichen Geschichte, t. 35).

Neitmann K., Der Hochmeister des Deutschen Ordens in Preußen - ein Residenzherrscher unterwegs, Köln-Wien 1990 (Veröffentlichungen aus den Archiven Preussischer Kulturbesitz, t. 30).

Neitmann K., Jagdbriefe im diplomatischen Verkehr des Deutschen Ordens mit Polen-Litauen um 1400 , „Preussenland” 24, 1986, nr 2, s. 25-33.

Neitmann K., Die Staatsverträge des Deutschen Ordens in Preussen 1230-1449. Studien zur Diplomatie eines spätmittelalterlichen Territorialstaates, Köln-Wien 1986 (Neue Forschungen zur Brandenburg-Preussischen Geschichte, t. 6).

Neitmann K., Was ist eine Residenz? Methodische Überlegungen zur Erforschung der spätmittelalterlichen Residenzbildung, w: Vorträge und Forschungen zur Residenzfrage, red. P. Johanek, Sigmaringen 1990 (Residenzforschung, t. 1), s. 11-43.

Nikodem J., Witold, wielki książę litewski (1354 lub 1355 - 27 października 1430 roku), Kraków 2013.

Nowakowski A., Księżna Anna Witoldowa a Krzyżacy, w: Archaeologia et historia. Ksiega jubileuszowa dedykowana Pani Profesor Romanie Barnycz-Gupieńcowej, Łódź 2000, s. 289-297.

Paravicini W., Die Preussenreisen des europäischen Adels, cz. 2, Sigmaringen 1995 (Beihefte der Francia. t. 17/2).

Petrauskas R., Didžiojo kunigaikščio institucinio dvaro susiformavimas Lietuvoje (XIV a. pabaigoje $X V$ a. viduryje), „Lietuvos istorijos metraštis” 2005 [2006], nr 1, s. 5-38.

Petrauskas R., Iki ir po didžiojo mūšio. Politiniai pokyčiai Rytų Pabaltijyje Žalgirio mūšio epochoje, w: Jogailos ir Vytauto laikai. Moksliniu straipsniu rinkinys, skirtas Žalgirio mūšio 600-osioms metinems, Kaunas 2011, s. 8-20.

Petrauskas R., Kształtowanie się instytucji dworu wielkoksiążęcego w Wielkim Księstwie Litewskim (koniec XIV - połowa XV wieku), „Politeja” 2011, nr 2(16), s. 155-185.

Petrauskas R., Lietuvos Didžioji Kunigaikštystè ir universalus Romos, Vengrijos bei Čekijos karaliaus Zigmanto Liuksemburgo pasaulis, w: E. Windecke, Imperatoriaus Zigmanto knyga: XV a. Lietuvos valdovu portretai. Pasakojimai ir vaizdai, red. J. Kiaupiene, R. Petrauskas, Vilnius 2015, s. 9-35.

Petrauskas R., Vytauto dvaras. Struktūra ir kasdienybè, „Naujasis Židinys - Aidai” 2003, nr 1-2, s. 39-44.

Peyer H.C., Das Reisekönigtum des Mittelalters, „Vierteljahrschrift für Sozial- und Wirtschaftsgeschichte" 51, 1964, s. 1-21.

Pietkiewicz K., Itinerarium króla Aleksandra Jagiellończyka 1492-1506, Warszawa 2016 (Itineraria Jagiellonów, t. 3). 
Polechow S., Kilka uwag historyka Wielkiego Księstwa Litewskiego do itinerarium Kazimierza Jagiellończyka. [Rec.:] Grażyna Rutkowska: Itinerarium króla Kazimierza Jagiellończyka 1440-1492. Warszawa, Wydawnictwo Neriton, 2014, ss. 422, 8 s. map, „Średniowiecze Polskie i Powszechne” 8, 2016, s. 287-299.

Prochaska A., Dzieje Witolda, w. księcia Litwy, Wilno 1914.

Prochaska A., Z Witoldowych dziejów, „Przegląd Historyczny” 15, 1912, nr 3, s. 264-267.

Purc J., Itinerarium Witolda wielkiego księcia Litwy (17 lutego 1370 roku - 27 października 1430 roku), w: Studia z dziejów Wielkiego Księstwa Litewskiego XIV-XVIII wieku, Poznań 1971 (Zeszyty Naukowe Uniwersytetu im. A. Mickiewicza, Seria: Historia, z. 11), s. 71-115.

Quirini-Popławska D., Włoski handel czarnomorskimi niewolnikami w późnym średniowieczu, Kraków 2002.

Ragauskienė R., Lietuvos valdovu vilnietiški itinerariumai, w: Vilniaus žemutiné pilis XIV a. - XIX a. pradžioje. 2002-2004 m. istoriniu šaltiniu paieškos, Vilnius 2006, s. 304-330.

Rimša E., Lietuvos didžiojo kunigaikščio Vytauto antspaudai ir žemiu heraldika, Vilnius 2016.

Rowell S.C., Ne visai primintinos kautynès. Ką byloja šaltiniai apie 1399 m. mūš̨̧ ties Vorsklos upe?, „Istorijos šaltinių tyrimai” 1, 2008, s. 67-89.

Rozbiór krytyczny Annalium Poloniae Jana Dlugosza z lat 1385-1444, t. 1, Wrocław-Warszawa-Kraków 1961.

Rutkowska G., Itinerarium króla Kazimierza Jagiellończyka 1440-1492, Warszawa 2014 (Itineraria Jagiellonów, t. 1).

Rutkowska G., Itinerarium królowej Jadwigi 1384-1399, w: Dzieło Jadwigi i Jagiełty. W sześćsetlecie chrztu Litwy i jej związków z Polską, Warszawa 1989, s. 204-225.

Rutkowska G., Podróże polskich królowych $w$ XV wieku, w: Samotrzeć, w kompanii czy z orszakiem? Społeczne aspekty podróżowania w średniowieczu i w czasach nowożytnych, red. M. Saczyńska, E. Wółkiewicz, Warszawa 2012, s. 175-197.

Rutkowska G., Stacje Jagiellonów na Litwie, w: Jagiellonowie i ich świat. Dynastia królewska w drugiej połowie XV i w XVI wieku, red. B. Czwojdrak, J. Sperka, P. Węcowski, Kraków 2015 (Studia Jagiellonica, t. 2), s. 187-195.

Rutkowski A., Objazdy i system rządzenia państwem przez Kazimierza Wielkiego, „Kwartalnik Historyczny" 85, 1978, nr 3, s. 605-626.

Schwedler G., Herrschertreffen des Spätmittelalters: Formen - Rituale - Wirkungen, Ostfildern 2008 (Mittelalter-Forschungen, t. 21).

Seggern H. von, Herrschermedien im Spätmittelalter. Studien zur Informationsübermittlung im burgundischen Staat unter Karl dem Kühnen, Ostfildern 2003 (Kieler Historische Studien, t. 41).

Sochacka A., Mikroregion ostrowski w średniowieczu - powstanie osady i parafii, w: Dzieje Ostrowa Lubelskiego, red. R. Szczygieł, Ostrów Lubelski 1998, s. 33-58.

Sochaniewicz K., Najdawniejsze dyplomy Witolda w. ks. litewskiego (Przyczynek do dyplomatyki litewskiej), „Ateneum Wileńskie” 3, 1925-1926, s. 374-386.

Sperka J., Szafrańcowie herbu Stary Koń. Z dziejów kariery i awansu w późnośredniowiecznej Polsce, Katowice 2001.

Starzyński M., Litwa i Litwini w ksieggach rachunkowych średniowiecznego Krakowa (czasy Jagiełty $i$ Witolda), „Średniowiecze Polskie i Powszechne” 4, 2012, s. 220-229.

Starzyński M., Nad średniowiecznymi księgami rachunkowymi miasta Krakowa, „Roczniki Historyczne" 74,2008 , s. 165-178.

Szweda A., Habitacula omnibus proventibus et commeatibus referta. Problemy zaopatrzenia $w \dot{z} y w-$ ność podczas zjazdów polsko-litewsko-krzyżackich w I połowie XV wieku, w: Dobrou chut', velkoměsto, Praha 2007, s. 27-51.

Szweda A., Listy Władysława Jagiełly do wielkich mistrzów krzyżackich w latach 1386-1434, w: Tekst źródła, krytyka, interpretacja, red. B. Trelińska, Warszawa 2005, s. 253-272. 
Szweda A., Organizacja i technika dyplomacji polskiej w stosunkach z zakonem krzyżackim w Prusach w latach 1386-1454, Toruń 2009.

Szweda A., Po wielkiej wojnie. Zjazdy polsko-krzyżackie w 1411 roku, w: Kancelaria wielkich mistrzów i polska kancelaria królewska $w$ XV wieku. Materiały $z$ międzynarodowej konferencji naukowej, Malbork 2-3 IX 2004, red. J. Trupinda, Malbork 2006, s. 267-298.

Szybkowski S., Kancelaria wielkiego księcia Witolda $w$ dobie wielkich konfliktów z Zakonem Krzyzackim w latach 1409-1422. Organizacja, zadania, personel, w: Kancelaria wielkich mistrzów i polska kancelaria królewska w XV wieku, red. J. Trupinda, Malbork 2006, s. 299-318

Szybkowski S., Polish Staff as a Social Group in the Chancery of Grand Duke Witold, „Quaestiones Medii Aevi Novae" 3, 1998, s. 75-94

Śliwiński J., Krzyżackie przywileje wolnego polowania dla Władysława Jagiełty $i$ Witolda $w$ latach 1398-1420, w: Odkrywcy, princepsi, rozbójnicy, red. B. Śliwiński, Gdańsk 2007 (Studia z Dziejów Średniowiecza, t. 13), s. 333-348.

Tęgowski J., Rola Grodna w składzie Wielkiego Księstwa Litewskiego w XIV i początkach XV wieku, w: Гарадзенскі палімпсест 2012. Людзі даўняй Гародні. XV-XX cmcm., red. А.Ф. Смаленчука, Н.У. Сліж, Гродна 2013, s. 60-71.

Tęgowski J., Sprawa przyłączenia Podola do Korony Polskiej w końcu XIV wieku, „Teki Krakowskie” 5, 1997, s. 155-176.

Tęgowski J., Uzupełnienia i uwagi do itinerarium Witolda Kiejstutowicza, „Studia Źródłoznawcze” 44, 2006, s. 67-76.

Valionienė O., Viduramžiu Vilnius. Erdvés evoliucija (XIII a. vidurys - XVI a. pirmas ketvirtis), Vilnius 2019.

Vander Linden H., Itinéraires de Philippe le Bon, duc de Bourgogne (1419-1467) et de Charles, comte de Charolais (1433-1467), Bruxelles 1940.

Voigt J., Geschichte Preußens, t. 6, Königsberg 1834.

Volungevičius V., Pilies šešèlyje. Teritorija, visuomene ir valdžia Lietuvos Didžiojoje Kunigaikštystèje, Vilnius 2015.

Wawrzyńczyk A., Rozwój wielkiej własności na Podlasiu w XV i XVI wieku, Wrocław 1951.

Węcowski P., Polskie itineraria średniowieczne i nowożytne. Przegląd badań i propozycje badawcze, „Studia Źródłoznawcze” 37, 2000, s. 13-48.

Wilkiewicz-Wawrzyńczykowa A., Spory graniczne polsko-litewskie w XV-XVII w., „Wiadomości. Studium Historii Prawa Litewskiego" 1, (Wilno) 1938, s. 93-201.

Wiśniewski J., Osadnictwo wschodniej Białostocczyzny: geneza, rozwój oraz zróżnicowanie i przemiany etniczne, „Acta Baltico-Slavica” 11, 1977, s. 7-80.

Wrede M., Itinerarium króla Stefana Batorego 1576-1586, Warszawa 2010.

Wróbel D., Elity polityczne Królestwa Polskiego wobec problemu krzyżackiego w czasach Władysława Jagiełty, Lublin 2017.

Wysłouch S., Posługi komunikacyjne w miastach Wielkiego Księstwa Litewskiego na prawie magdeburskiem do połowy XVI wieku, Wilno 1936.

Zawitkowska W., Walka polityczno-prawna o następstwo tronu po Władystawie Jagielle $w$ latach 1424-1434, Rzeszów 2015.

Аракчеев В.А., Писцовые книги и локализация летописных топонимов, w: Рефераты докладов и сообщений VI Всероссийского научно-практического совещения по изучению и изданию писиовых книг и других историко-геограбических источников (Ферапонтово, 27-29 мая 1993 г.), Санкт-Петербург 1993, s. 68-71.

Афанасенко Ю., Новогрудский собор 1415 г. в церковной политике великого князя Витовта, „Studia Historica Europae Orientalis” 8, 2015, s. 91-122.

Баранаускас Т., Новогрудок в ХІІІ в. История и миф, w: Castrum, urbis et bellum: Зборнік навуковых праи, Баранавічы 2002, s. 29-44. 
Барвіньский Б., Історичні причинки, t. 1, Жовква 1908.

Бассалыго Л.А., Янин В.Л., Историко-географический обзор новгородско-литовской границы, w: В.Л. Янин, Новгород и Литва: Пограничные ситуации ХІІІ-XV веков, Москва 1998, s. $154-158$.

Белецкая О., Имя великого князя литовского Витовта в названиях Северного Причерноморья XVI-XVIII веков, „Lietuvos istorijos studijos” 42, 2018, s. 7-25.

Бережков Н.Г., Итинерарий великих князей литовских по материалам Литовской метрики (1481-1530 г2.), „Археографический ежегодник за 1961 год” 1962, s. 180-205.

Беспалов Р.А., Источники о поездке Витовта в область Новосильского и Рязанского княжеств в 1427 году, w: Верхнее Подонье: археология, история, t. 3, Тула 2008, s. 256-259.

Беспалов Р.А., К вопросу о времени запустения южной части Новосильско-Одоевского княжества, w: Город Средневековья и раннего Нового времени: археология, история. Материалы IV всероссийского семинара. Ноябрь 2011 г., red. И.Г. Бурцев, Тула 2013, s. 87-92.

Беспалов Р.А., Литовско-московские отнотения 1392-1408 годов в связи со смоленской, черниговской и рязанской политикой Витовта и Василия I, „Средневековая Русь” 12, 2016, s. $129-182$.

Вайткявичюс Г., Вильнюс: от поселения до королевского города, w: Археология и история Литвы и Северо-Запада России в Средневековье. Доклады российско-литовского семинара. Вильнюс, 28-30 марта 2011 г., Вильнюс 2013, s. 81-107.

Варонін В.А., Да пытання аб часе і абставінах ухавання грашова-рэчавага скарбу каля вёскі Літва Маладзечанскага раёна Мінскай вобласиі, „Studia Numismatica Albaruthenica” 1, 2011, s. 94-106.

Варонін В.А., Падзеі 1307 года у Полачку. Спроба крытычнага разбору, w: Гісторыя і археалогія Полацка і Полацкай зямлі. Матэрыяль V Міжнароднай навуковай канферэнцы (24-25 кастрычніка 2007 г.), Полацк 2009, s. 30-40.

Волкаў М., Архітэктура Старога замка часоў Вітаўта ў Гародні, „Беларускі гістарычны часопіс" 2014, nr 2, s. 17-34.

Воронин В.А., Княжение Ольгерда в Витебске, „Ukraina Lituanica. Студії з історії Великого князівства Литовського" 2, 2013, s. 21-38.

Вялікі гістарычны атлас Беларусі у 3-х тамах, t. 1, Мінск 2009.

Груша А.И., Документальная письменность Великого Княжества Литовского (конеи XIV первая треть XVI в.), Минск 2015.

Груша А.И., Кризис доверия? Появление и утверждение правового документа в Великом княжестве Литовском (конеи, XIV - первая треть XVI в.), Москва-Санкт-Петербург 2019.

Доўнар-Запольскі М.В., Дзяржаўная гаспадарка Вялікага княства Літоўскага пры Ягелонах, Мінск 2009.

Залилов И.З., Граффити Спасо-Преображенской церкви в Полоике XII-XVII вв., Полоцк 2014.

Иванов Д.И., Московско-литовские отночения в 20-е годы XV столетия, „Средневековая Русь” 2, 1999, s. 79-115.

Игошина Т.Ю., Двор верховного магистра Немецкого ордена в Пруссии в коние XIV - начале $X V$ веков, Москва 2000.

Калечыц І.Л., Эпиграфіка Беларусі X-XIV стст., Мінск 2011.

Карамзин Н.М., История государства Российского, t. 5, Москва 1993.

Келембет С., Федір-Федот (Федюшко) Любартович, князь луиький і володимирський, державия сіверський, „Сіверянський літопис” 2018, nr 6(144), s. 13-36.

Конявская Е.Л., Хронологические вехи и расчеты в древнерусских летописях и актах, w: Русь, Россия: Средневековье и Новое время, t. 4: Четвёртые чтения памяти академика РАН Л.В. Милова. Материалы к международной научной конференции, Москва, 26 октября 1 ноября 2015 г., Москва 2015, s. 133-138. 
Кушнярэвіч А.М., Мураваная дабастыённая фартыфікацыя Вялікага Княства Літоўскага, Мінск 2014.

Лаўрэш Л.Л., Месиа заключэння Востраўскага пагаднення 1392 г., w: Ліда і Лідчына: да 685-годдзя з дня заснавання горада. Матэрыялы навукова-практычнай канферэнцыьі (Ліда, 3 кастрычніка 2008 г.), Ліда 2008, s. 44-48.

Ліцкевіч А.У., Гародня і Гарадзенскі рэгіён у другой палове XIII-XIV cmcm. Назва і межь, „Гарадзенскі палімпсест” 2012, [2013], s. 10-59.

Ліцкевіч А.У., Гародня і Гарадзенскі рэгіён у другой палове XIII-XIV cmcm. Сухапутныя і водныя камунікацьі, населенья пункты, этнаканфесійны склад і міграцыі насельніцтва, „Arсhе” 2014, nr 11: Гарадзенскі міленіум, s. 8-60.

Ліцкевіч А.У., Пра некаторыя спісы „Летапісиа вялікіх князёў літоўскіх” маскоўскага і наўгародскага паходжання (на маргінезе выданняу М. Улашчыка і В. Вароніна), w: Вялікае княства Літоўскае і яго суседзі у XIV-XV стст. Саперніцтва, супрацоўніцтва, урокі, Мінск 2011, s. 207-223.

Ліцкевіч А.У., „Срэбны каваль” Хацабей з-пад Маладзечна (XV cm.). Ящчэ раз пра магчымае паходжанне срэбных паясных набораў са скарбу каля в. Літва, „Беларуская даўніна” 1, 2014, s. 109-121.

Лукин П.В., Праздник, пир и вече. К вопросу об архачческих чертах общественного строя восточных и западных славян, „Одиссей. Человек в истории. Феодализм перед судом историков" 2006, s. 134-150.

Любавский М.К., Литовско-русский сейм. Опьт по истории учреждения в связи с внутренним строем и внешнею жизнью государства, Москва 1900.

Любавский М.К., Поседные бояре в Жмудской земле в XVI веке, w: Сергею Фёдоровичу Платонову ученики, друзья и почитатели, Санкт-Петербург 1911, s. 439-449.

Любащенко B.I., Галич у иерковно-унійних планах Владислава Ягайла $і$ митрополита Кипріяна, „Україна: культурна спадщина, національна свідомість, державність” 20, 2011, s. $434-452$.

Михайловський В., Podole po Grunwaldzie (1410-1430). Walka Witolda z Jagiełta, w: Jogailos ir Vytauto laikai. Moksliniu straipsniu rinkinys, skirtas Žalgirio mūšio 600-osioms metinems, Kaunas 2011, s. 117-125.

Михайловський В., Західне Поділля під володінням Вітовта у 1411-1430 роках. Надавча політика у світлі документів, w: До джерел. Збірник наукових пращь на почану Олега Купчинського з нагоди його 70-річчя, t. 2, Київ-Львів 2004, s. 110-128.

Мяцельскі А.А., Мсизіслаускае княства і ваяводства у ХII-XVIII стст., Мінск 2010.

Насевіч В.Л., Літва у ХIV cm., „Беларуская даўніна” 3, 2016, s. 5-44.

Полехов С.В., Браки князя Свидригайла Ольгердовича, w: По любви, въ правду, безо всякие хитрости, Москва 2014, s. 235-268.

Полехов С.В., Загадка грамоты Витовта (Vitoldiana, № 11): XIV или XIX век?, „Slověne” 7, 2018, nr 2, s. 272-297.

Полехов С.В., Литовская Русь в XV в. Единая или разделённая? (На материале конфликтов между русскими землями Великого княжества Литовского и государственным иентром), w: Древняя Русь после Древней Руси. Дискурс восточнославянского (не)единства, Москва 2017, s. 70-92.

Полехов С.В., Лугвень, Новгород и восточная политика Витовта (1411-1414) в свете малоизвестных источников Кёнигсбергского архива, ш: Мсціслаў і Мсціслаўскі край, Мінск 2019, s. 58-78.

Полехов С.В., Наследники Витовта. Династическая война в Великом княжестве Литовском в 30-е годы XV века, Москва 2015.

Полехов С.В., Последние завещания Василия I и печати Витовта, „Средневековая Русь” 12, 2016, s. 183-200. 
Полюдье: всемирно-историческое явление, red. Ю.М. Кобищанов, Москва 2009.

Словарь древнерусского языка XI-XIV вв., t. 2, Москва 1989.

Собчук В.Д., Від коріння до крони. Дослідження з історії князівських і шляхетських родів Волині XV - першої половини XVII cm., Кременець 2014.

Стефанович П.С., История полюдья в средневековой Руси (X-XVI вв.), „Российская история” 2017, nr 6, s. 3-13.

Турилов А.А., Жалованная грамота Любарта Гедеминовича Луцякой кафедре и ситуация на Волыни после гибели галицко-вольнских Рюриковичей, w: Восточная Европа в древности и средневековье. Проблемы источниковедения. XVII Чтения памяти чл.-корр. АН СССР В. Т. Пашуто; IV Чтения памяти д. и. н. А. А. Зимина, Москва, 19-22 апреля 2005 г., t. 2, Москва 2005, s. 266-268.

Флоря Б.Н., Исследования по истории Церкви: древнерусское и славянское Средневековье, Москва 2007.

Sergiej Polechow (Сергей Полехов, Sergey Polekhov) - dr (kandydat nauk historycznych), starszy pracownik naukowy w Instytucie Historii Rosji Rosyjskiej Akademii Nauk (Moskwa), starszy pracownik naukowy w Szkole Aktualnych Badań Humanistycznych Instytutu Nauk Społecznych Rosyjskiej Akademii Gospodarki Ludowej i Służby Państwowej (Moskwa). Autor książki: Наследники Витовта. Династическая война в Великом княжестве Литовском в 30-е годы XV века, Москва 2015; współwydawca: Полоцкие грамоты XIII - начала XVI века, t. 1-2, oprac. А.Л. Хорошкевич, С.В. Полехов, В.А. Воронин, А.И. Груша, А.А. Жлутко, Е.Р. Сквайрс, А.Г. Тюльпин, Москва 2015. Jego zainteresowania badawcze obejmują dzieje społeczno-polityczne Wielkiego Księstw Litewskiego w okresie od XIII do połowy XVI w., dzieje Rusi i Europy w średniowieczu, badania źródłoznawcze, edytorstwo źródeł historycznych. Obecnie przygotowuje do druku Kodeks dyplomatyczny Świdrygiełty. E-mail: sergey.polekhov@gmail.com 